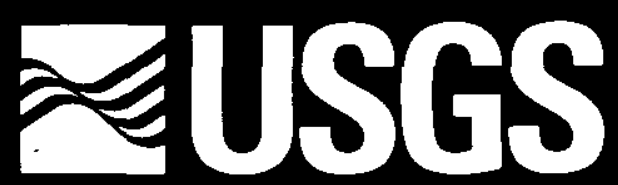

science for a changing world

Prepared in cooperation with the

MASSACHUSETTS DEPARTMENT OF ENVIRONMENTAL MANAGEMENT,

OFFICE OF WATER RESOURCES

\title{
Methods for Estimating Low-Flow Statistics for Massachusetts Streams
}

Water-Resources Investigations Report 00-4135

U.S. Department of the Interior

$2 \div 00$

U.S. Geological Survey 
U.S. Department of the Interior

U.S. Geological Survey

\section{Methods for Estimating Low-Flow Statistics for Massachusetts Streams}

By KERNELL G. RIES, III and PAUL J. FRIESZ

Water-Resources Investigations Report 00-4135

Prepared in cooperation with the

MASSACHUSETTS DEPARTMENT OF ENVIRONMENTAL MANAGEMENT,

OFFICE OF WATER RESOURCES

Northborough, Massachusetts

2000 


\section{U.S. DEPARTMENT OF THE INTERIOR \\ BRUCE BABBITT, Secretary}

U.S. GEOLOGICAL SURVEY

Charles G. Groat, Director

The use of trade or product names in this report is for identification purposes only and does not constitute endorsement by the U.S. Geological Survey.

For additional information write to:

Chief, Massachusetts-Rhode Island District

U.S. Geological Survey

Water Resources Division

10 Bearfoot Road

Northborough, MA 01532

or through our web site at

http://ma.water.usgs.gov
Copies of this report can be purchased from:

U.S. Geological Survey

Branch of Information Services

Box 25286

Denver, CO 80225-0286 


\section{CONTENTS}

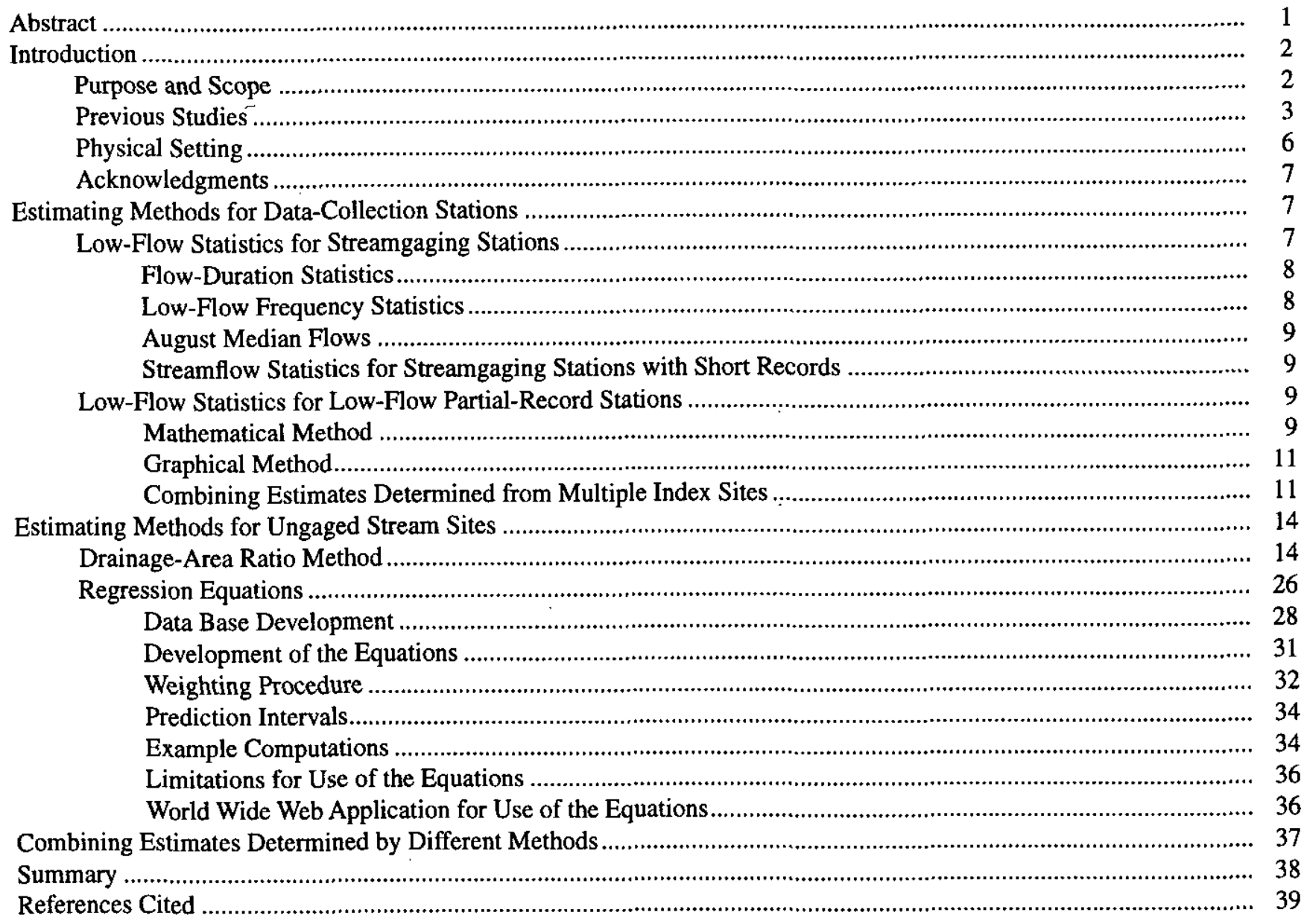

\section{FIGURES}

1. Map showing locations of streamgaging stations and low-flow partial-record stations used to develop equations for estimating low-flow statistics for ungaged Massachusetts streams and locations of streamgaging stations outside Massachusetts used for correlation with low-flow partial-record stations, and boundaries of the 27 major river basins and three hydrologic regions in the State

2, 3. Graph showing:

2. Example MOVE.1 relation between a low-flow partial-record station, Hemlock Brook near Williamstown, Mass., and a streamgaging station, Green River at Williamstown, Mass.

3. Example graphical relation between a low-flow partial-record station, Hopping Brook near West Medway, Mass., and a streamgaging station, West River near Uxbridge, Mass.

4. Maps showing locations and drainage boundaries of low-flow partial-record stations and gaging stations in the $(A)$ Squannacook, $(B)$ Wading, $(C)$ Quaboag, $(D)$ Green, and

$(E)$ West Branch Westfield River Basins.

5. Relation of drainage-area ratio to average absolute percent difference in streamflow statistics between data-based estimates and estimates derived from the drainage-area ratio method, and from the regression equations. 


\section{TABLES}

1. Descriptions of low-flow partial-record and streamgaging stations used to analyze the applicability of the drainage-area ratio method for estimating streamflow statistics for ungaged Massachusetts streams.

2. Medians and standard deviations of absolute percent differences between streamflow statistics estimated using available data and by using the drainage area ratio method and regression equations.....

3. Descriptions of streamgaging stations used in the regression analyses or for correlation with low-flow partial-record stations, or both

4. Summary of regression equations developed for estimating low-flow statistics for

Massachusetts streams

5. Values needed to determine 90-percent prediction intervals for estimates obtained from the equations

6. Ranges of basin characteristics used to develop the regression equations

7. Low-flow statistics estimated using available data, the drainage-area ratio method, and regression equations; and absolute percent differences between the data-based estimates and estimates from the drainage-area ratio method and regression equations for stations used to analyze to applicability of the drainage-area ratio method for estimating low-flow statistics for ungaged Massachusetts streams

8. Descriptions of low-flow partial-record stations used in the regression analyses

9. Streamflow statistics, variances, standard errors, and years of record for stations included in the regression analyses.

10. Basin characteristics for stations used in the regression analyses 77

\section{CONVERSION FACTORS. VERTIICAL DATUM, ACRONYMS AND ABBREVIATIONS}

CONVERSION FACTORS

\begin{tabular}{rcl}
\hline Multiply & \multicolumn{1}{c}{ By } & To obtain \\
\hline cubic foot $\left(\mathrm{ft}^{3}\right)$ & 0.02832 & cubic meter \\
cubic feet per second $\left(\mathrm{ft}^{3} / \mathrm{s}\right)$ & 0.02832 & cubic meter per second \\
foot $(\mathrm{ft})$ & 0.3048 & meter \\
inch (in) & 25.4 & millimeter \\
mile (mi) & 1.609 & kilometer \\
square mile $\left(\mathrm{mi}^{2}\right)$ & 2.590 & square kilometer \\
Temperature in degrees Fahrenheit $\left({ }^{\circ} \mathrm{F}\right)$ can be converted \\
to degrees Celsius $\left({ }^{\circ} \mathrm{C}\right)$ as follows: \\
\\
${ }^{\circ} \mathrm{C}=5 / 9 \times\left({ }^{\circ} \mathrm{F}-32\right)$ & \\
\hline
\end{tabular}

\section{VERTICAL DATUM}

Sea level: In this report, "sea level" refers to the National Geodetic Vertical Datum of 1929 (NGVD of 1929) - a geodetic datum derived from a general adjustment of the first-order level nets of the United States and Canada, formerly called Sea Level Datum of 1929. 


\section{Organizations}

MOWR Massachusetts Department of Environmental Management, Division of Resource Conservation, Office of Water Resources

USGS U.S. Geological Survey

USFWS U.S. Fish and Wildlife Service

\section{Basin Characteristics}

DA Drainage area, in square miles

DR Area of stratified-drift deposits, in square miles

DR/ST Area of stratified drift per unit stream length

SLOPE Mean basin slope, in percent

REG Region, 0 in eastern Massachusetts, 1 in westem Massachusetts

\section{Miscellaneous}

AML A programming language for automating tasks with the Arc/Info GIS software developed by the Environmental Systems Research Institute, Inc.

BCF Bias correction factor

DEM Digital elevation model of topography

GIS Geographic information system computer software

GLS Generalized-least-squares regression analysis

LFPR Low-flow partial-record station

OLS Ordinary-least-squares regression analysis

MAD Median absolute deviation, in percent

MOVE.1 Maintenance of variance extension, type 1, method of correlation

MSE Mean square enror of regression

MVUE Minimum variance unbiased estimate of retransformation bias correction

PRESS Prediction error sum of squares

WLS Weighted-least-squares regression analysis 


\title{
Methods for Estimating Low-Flow Statistics for Massachusetts Streams
}

\author{
By Kernell G. Ries, III, and Paul J. Friesz
}

\section{Abstract}

Methods and computer software are described in this report for determining flowduration, low-flow frequency statistics, and August median flows. These low-flow statistics can be estimated for unregulated streams in Massachusetts using different methods depending on whether the location of interest is at a streamgaging station, a low-flow partial-record station, or an ungaged site where no data are available. Lowflow statistics for streamgaging stations can be estimated using standard U.S. Geological Survey methods described in the report.

The MOVE. 1 mathematical method and a graphical correlation method can be used to estimate low-flow statistics for low-flow partialrecord stations. The MOVE. 1 method is recommended when the relation between measured flows at a partial-record station and daily mean flows at a nearby, hydrologically similar streamgaging station is linear, and the graphical method is recommended when the relation is curved. Equations are presented for computing the variance and equivalent years of record for estimates of low-flow statistics for low-flow partialrecord stations when either a single or multiple index stations are used to determine the estimates.

The drainage-area ratio method or regression equations can be used to estimate low-flow statistics for ungaged sites where no data are available. The drainage-area ratio method is generally as accurate as or more accurate than regression estimates when the drainage-area ratio for an ungaged site is between 0.3 and 1.5 times the drainage area of the index data-collection site.
Regression equations were developed to estimate the natural, long-term 99-, 98-, 95-, 90-, 85-, 80-, 75-, 70-, 60-, and 50-percent duration flows; the 7-day, 2-year and the 7-day, 10-year low flows; and the August median flow for ungaged sites in Massachusetts. Streamflow statistics and basin characteristics for 87 to 133 streamgaging stations and low-flow partial-record stations were used to develop the equations. The streamgaging stations had from 2 to 81 years of record, with a mean record length of 37 years. The low-flow partial-record stations had from 8 to 36 streamflow measurements, with a median of 14 measurements.

All basin characteristics were determined from digital map data. The basin characteristics that were statistically significant in most of the final regression equations were drainage area, the area of stratified-drift deposits per unit of stream length plus 0.1 , mean basin slope, and an indicator variable that was 0 in the eastern region and 1 in the western region of Massachusetts.

The equations were developed by use of weighted-least-squares regression analyses, with weights assigned proportional to the years of record and inversely proportional to the variances of the streamflow statistics for the stations. Standard errors of prediction ranged from 70.7 to 17.5 percent for the equations to predict the 7-day, 10-year low flow and 50-percent duration flow, respectively. The equations are not applicable for use in the Southeast Coastal region of the State, or where basin characteristics for the selected ungaged site are outside the ranges of those for the stations used in the regression analyses. 
A World Wide Web application was developed that provides streamflow statistics for datacollection stations from a data base and for ungaged sites by measuring the necessary basin characteristics for the site and solving the regression equations. Output provided by the Web application for ungaged sites includes a map of the drainage-basin boundary determined for the site, the measured basin characteristics, the estimated streamflow statistics, and 90-percent prediction intervals for the estimates.

An equation is provided for combining regression and correlation estimates to obtain improved estimates of the streamflow statistics for low-flow partial-record stations. An equation is also provided for combining regression and drainage-area ratio estimates to obtain improved estimates of the streamflow statistics for ungaged sites.

\section{INTRODUCTION}

Low-flow statistics indicate the probable availability of water in streams during times when conflicts between water supply and demand are most likely to arise. Because of this, low-flow statistics are needed by Federal, State, regional, and local agencies for water-use planning, management, and regulatory activities. These activities include (1) developing environmentally sound river-basin management plans, (2) siting and permitting new water withdrawals, interbasin transfers, and effluent discharges,

(3) determining minimum streamflow thresholds for maintenance of aquatic biota, and (4) land-use planning and regulation. Low-flow statistics are also needed by commercial, industrial, and hydroelectric facilities to determine availability of water for water supply, waste discharge, and power generation.

Low-flow statistics can be calculated from streamflow data collected at locations where the U.S. Geological Survey (USGS) operates data-collection stations, but it is not possible to operate stations at every site where the statistics are needed. Because of this, methods are needed for estimating low-flow statistics for streams for which no data are available.

In 1988, the USGS began the first of three studies to develop and evaluate methods for estimating low-flow statistics for ungaged Massachusetts streams and to provide estimates of the statistics for selected locations on ungaged streams. These studies were done in cooperation with the Massachusetts Department of Environmental Management, Office of Water Resources (MOWR) and are referred to as the Basin Yield studies. The MOWR uses the streamflow statistics to develop water-resources management plans for each of the 27 major river basins in Massachusetts (fig. 1) and provides the streamflow statistics to other State and local agencies to support their decisionmaking processes.

Five other reports have been published as a result of the Basin Yield studies (Ries, 1994a, 1994b, 1997, 1999, 2000). The first three reports describe studies done to develop regression equations for use in estimating low-flow statistics for ungaged sites. The fourth report describes and provides data for a network of 148 low-flow partial-record (LFPR) stations that was established in 1988 at the beginning of the first Basin Yield study and continued through 1996, during the third Basin Yield study. The fifth report describes a World Wide Web application that enables users to select sites of interest on streams and then to obtain estimates of streamflow statistics and basin characteristics for the sites.

\section{Purpose and Scope}

This report, the final report of the Basin Yield study series, presents methods that can be used to estimate low-flow statistics for streams in Massachusetts, and describes the analyses done to develop and evaluate the methods. Methods are presented for estimating statistics for locations where various amounts of streamflow data are available and for locations where no data are available. Previously documented and generally accepted methods are presented for estimating low-flow statistics for locations where streamflow data are available. Analyses done to develop and evaluate methods for estimating streamflow statistics for locations where no data are available are described. The physical setting of Massachusetts, as it relates to the occurrence of low streamflows, is also briefly described.

Equations that can be used to estimate the 99-, 98-, 95-, 90-, 85-, 80-, 75-, 70-, 60-, and 50-percent duration flows; the 7-day, 2-year and the 7-day, 10-year low flows; and the August median flow are presented here. An evaluation of the accuracy of the equations and limitations for their use is also provided, along 
with an example application. The equations provide estimates of low-flow statistics for streams with natural flow conditions, and supersede those from earlier reports.

\section{Previous Studies}

Low-flow statistics for most streamgaging stations and many LFPR stations in Massachusetts were published by the USGS in a series of gazetteers published as Water-Resources Investigations Reports, in a series of Hydrologic Atlas reports (see U.S. Geological Survey, 1987, for a complete listing of both series), and in a series of ground-water assessment reports published as Water-Resources Investigations Reports (Olimpio and DeLima, 1984; Lapham, 1988; Myette and Simcox, 1992; DeLima, 1991; Hanson and Lapham, 1992; Persky, 1993; Bratton and Parker, 1995; Bent, 1995; Friesz, 1996; Klinger, 1996). Statistics provided in this report supersede those from the previous reports.

Studies that used regression analysis to regionalize low-flow frequency statistics in the northeastern United States include those for Connecticut (Cervione, 1982), central New England (Wandle and Randall, 1994), Pennsylvania and New York (Ku and others, 1975), Maine (Parker, 1977), Massachusetts, New Hampshire, Rhode Island and Vermont (Johnson, 1970), southeastern Massachusetts (Tasker, 1972), and Massachusetts (Male and Ogawa, 1982; Vogel and Kroll, 1990; Risley, 1994). Studies that regionalized flow-duration statistics include those for Connecticut (Thomas, 1966), New Hampshire (Dingman, 1978), southeastern Massachusetts (Tasker, 1972), and Massachusetts (Male and Ogawa, 1982; Fennessey and Vogel, 1990; Ries, 1994a, 1994b).

Reports for the first two Basin Yield studies (Ries, 1994a, 1994b) provided equations for estimating the 99-, 98-, and 95-percent duration streamflows and also provided estimates of the streamflow statistics and measured basin characteristics for selected ungaged streams in eastern Massachusetts river basins. The equations were developed for these studies by use of regression analyses, which statistically relate the streamflow statistics to measured basin characteristics for the stations used in the analysès. The studies differed in the methods of regression analysis used to develop the equations, the number of stations included in the analyses (more stations were used in the second study), and the locations of ungaged streams for which estimated streamflow statistics and basin characteristics were provided. The equations provided in the second report superseded those from the first report.

The third Basin Yield report (Ries, 1997) provides an equation for estimating August median streamflows. This statistic is used by the U.S. Fish and Wildlife Service (1981) and some State agencies as the minimum summertime streamflow required for maintenance of habitat for aquatic biota in New England. The report also provides estimates of August median streamflows for sites on unregulated streams in Massachusetts where the values could be determined from available data, and describes how the August median streamflow per square mile of drainage area varies throughout the State.

The LFPR network described in the fourth Basin Yield report (Ries, 1999a) was established to provide. additional data for use in the regression analyses and to provide a better understanding of the physical mechanisms that cause streamflow to vary in time and space. The report provides streamflow measurements collected systematically at the 148 LFPR stations in the network between 1989 and 1996, and also includes any historical streamflow measurements available for the stations. In addition, the report provides estimated streamflow statistics, basin characteristics, location and other descriptive information for each of the stations. The estimated streamflow statistics include the 99-, 98-, 97-, 95-, 93-, 90-, 85-, 80-, 75-, 70-, 65-, 60-, 55-, and 50-percent duration flows; the 7-day, 2-year and the 7-day, 10-year low flows; and the August median flow. Basin characteristics measured include drainage area; total stream length; mean basin slope; area of surficial stratified drift; area of wetlands; area of water bodies; and mean, maximum, and minimum basin elevation. The basin characteristics were measured for the stations from digital maps by use of a Geographic Information System (GIS).

The fifth Basin Yield report (Ries and others, 2000), a fact sheet, describes a World Wide Web application that includes (1) a mapping tool that allows users to specify locations on streams where low-flow statistics are needed, (2) a database that includes streamflow statistics, basin characteristics, location, and descriptive information for all data-collection stations in Massachusetts for which streamflow statistics were published previously, and (3) an automated GIS procedure that determines the required basin characteristics and solves the regression equations provided in this report to estimate low-flow statistics for the user-selected site. The World Wide Web application is further described later in this report. 


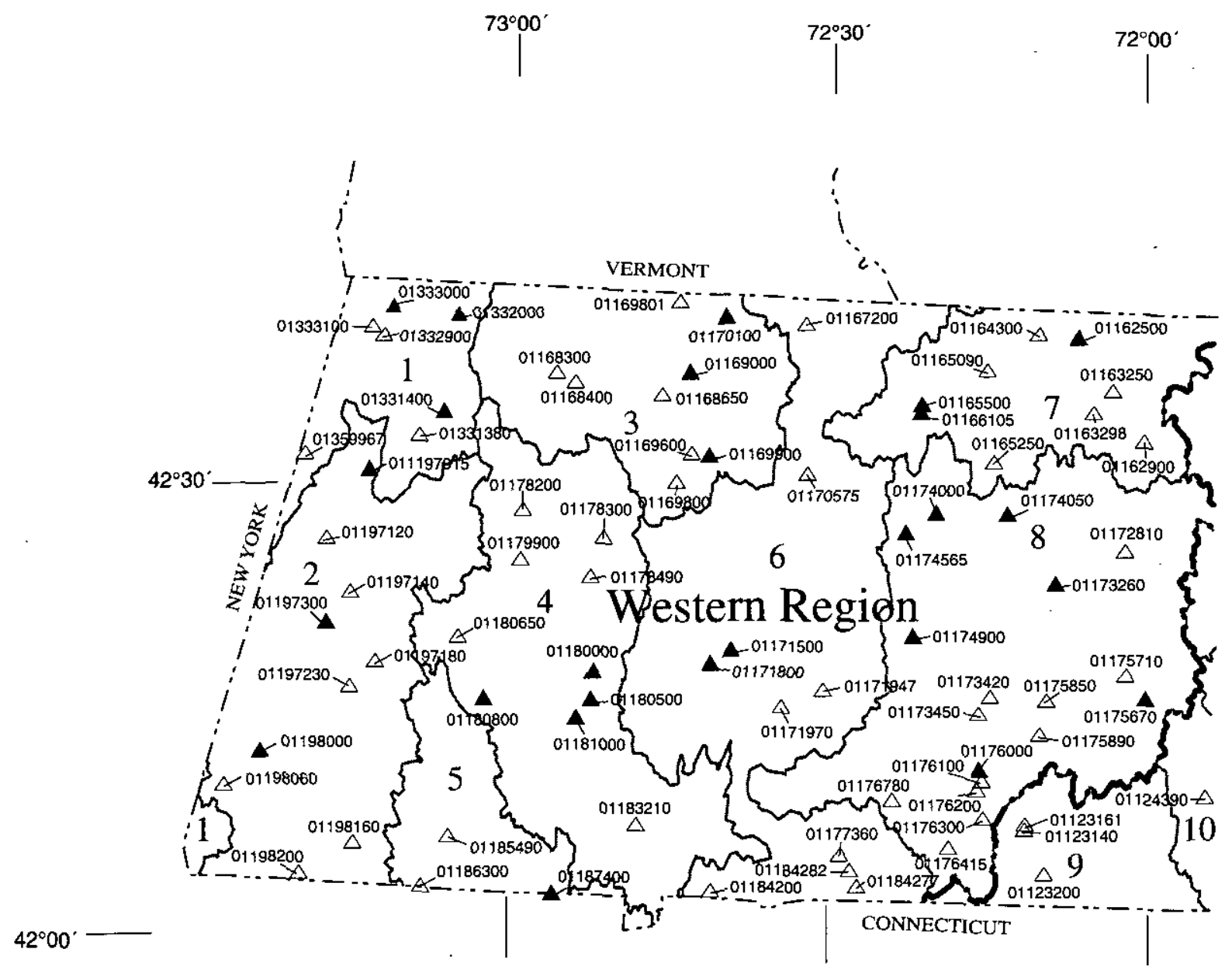

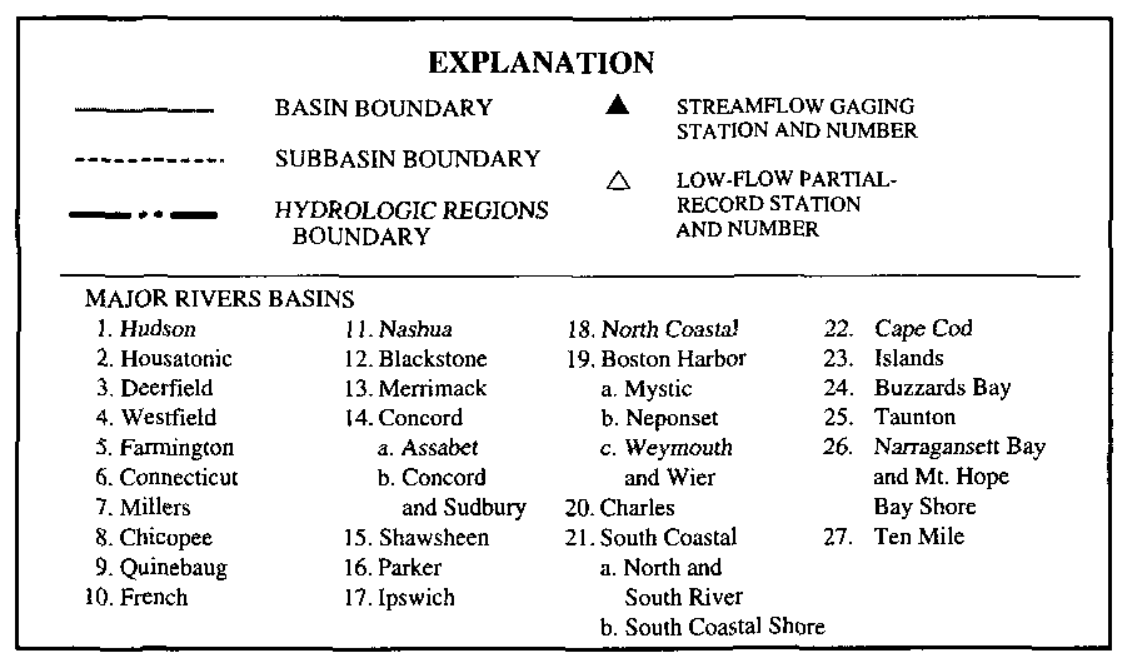

Figure 1. Locations of streamgaging stations and low-flow partial-record stations used to develop equations for estimating low-flow statistics for ungaged Massachusetts streams and locations of streamgaging stations outside Massachusetts used for correlation with low-flow partial-record stations, and boundaries of the 27 major river basins and three hydrologic regions in the State. 


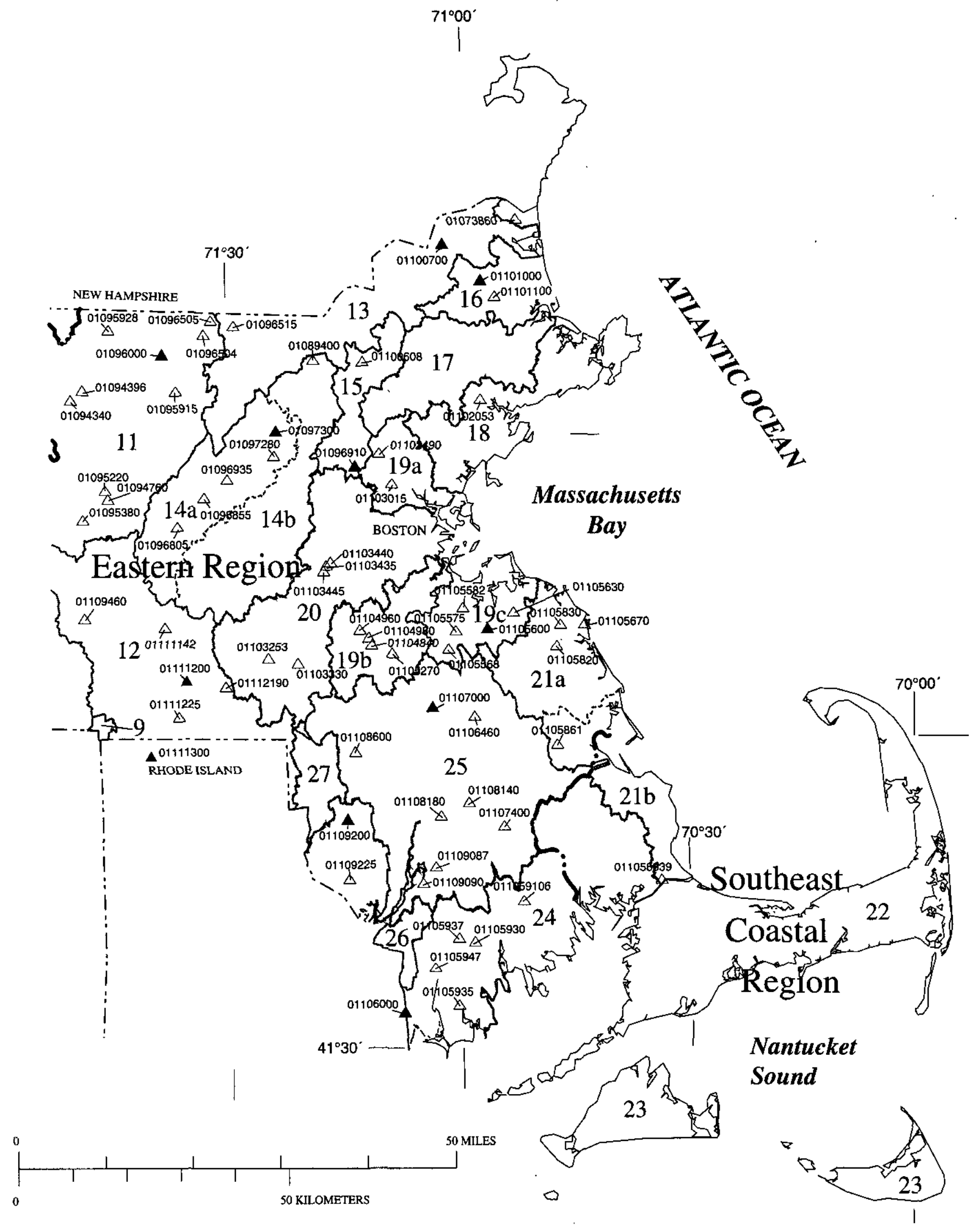

Figure 1. Locations of streamgaging stations and low-flow partial-record stations used to develop equations for estimating low-flow statistics for ungaged Massachusetts streams, locations of streamgaging stations outside Massachusetts used for correlation with low-flow partial-record stations, and boundaries of the 27 major river basins and three hydrologic regions in the State-Continued. 


\section{Physical Setting}

Massachusetts encompasses an area of $8,093 \mathrm{mi}^{2}$ in the northeastern United States. State environmental agencies divide Massachusetts into 27 major river basins for planning and regulatory purposes (fig. 1). Some of these designated river basins are actually part of larger river basins that extend into neighboring states. The Millers, Deerfield, Chicopee, and Westfield River Basins are part of the Connecticut River Basin. The Nashua, Concord, and Shawsheen River Basins are part of the Merrimack River Basin. Several designated basins in coastal areas of Massachusetts were comprised by grouping land areas drained by multiple streams that discharge to the same receiving body of salt water, such as Boston Harbor and Buzzards Bay.

The climate of Massachusetts is humid. Precipitation is distributed fairly evenly throughout the State and throughout the year, and averages about 45 in. annually. Average annual temperatures range from $50^{\circ} \mathrm{F}$ in coastal areas to $45^{\circ} \mathrm{F}$ in the western mountains. Average monthly temperatures range from about $30^{\circ} \mathrm{F}$ in February to about $71^{\circ} \mathrm{F}$ in July in coastal areas, and from about $20^{\circ} \mathrm{F}$ in January to about $68^{\circ} \mathrm{F}$ in July in the western parts of the State (U.S. Commerce Department, National Oceanic and Atmospheric Administration, 1989). Average evapotranspiration ranges from 19 in. in southeastern Massachusetts to 22 in. in the western Mountains (Randall, 1996).

Several physical characteristics vary from east to west in Massachusetts. Elevations range from sea level along the coast in eastern Massachusetts to almost $3,500 \mathrm{ft}$ in the western mountains. Basin relief and mean basin slope, which are highly related, also tend to increase from east to west in Massachusetts. The extent of lakes, ponds, and wetlands, as a proportion of total basin area, generally decreases from east to west in Massachusetts. The extent of coarse-grained stratified drift, as a proportion of total basin area, also generally decreases from east to west.

Except during and for a short time after storms, summertime flow in Massachusetts streams comes from ground water discharged by aquifers in unconsolidated deposits adjacent to the streams. This discharge is termed base flow. High-yielding aquifers usually are in stratified drift, sand and gravel deposits that are located primarily along the valley floors of inland river basins and in coastal areas of southeastern Massachusetts. The stratified-drift deposits usually are surrounded by upland areas underlain by till with exposed bedrock outcrops. Till is an unsorted glacial deposit that consists of material ranging in size from clay to large boulders. Till yields little water to adjacent streams in comparison to yields from coarse-grained stratified drift. As a result, during summertime, streams in till areas tend to have less flow per unit of drainage area than streams in areas of coarse-grain stratified drift, and some small streams in till areas may go dry (Wandle and Randall, 1994).

Ries (1997) defined three hydrologic regions in Massachusetts based on differences in August median streamflow per square mile of drainage area (fig. 1). These regions were the Western, the Eastern, and the Southeast Coastal regions. The Western region was defined by all major basins that drain to the Connecticut River plus those west of the Connecticut River Basin (basins 1 through 8 on fig. 1). The Eastern region was defined as all basins east of the Western region except Cape Cod, the Islands, the southern part of the South Coastal Basin, and the eastern part of the Buzzards Bay Basin, which define the Southeast Coastal region. August median flows per square mile were significantly higher, on average, in the Western region than in the Eastern region.

Differences in August median streamflow per unit area between the Western and Eastern regions appeared to be more a function of climate and physiography than surficial geology. Percentages of stratified-drift deposits were generally lower in the Western region than in the Eastern region, but August median streamflows were higher in the Western region than in the Eastern region. The higher low flows per unit area in the Western region than in the Eastern region is likely explained by the combination of lower mean annual temperatures, higher mean elevations, higher relief, higher precipitation, lower evapotranspiration, and lower areal percentages of wetlands and water bodies in western Massachusetts than in eastern Massachusetts.

The Southeast Coastal region is underlain entirely by stratified-drift deposits, which are mostly coarse grained. Surface-water drainage boundaries in this region often do not coincide with contributing areas of ground water for streams in the area. In addition, dam regulations, diversions, or controls by cranberry bogs affect most streams in the region. As a result, insufficient data were available to define the natural flow characteristics of streams in this region. 


\section{Acknowledgments}

The authors would like to thank the MOWR for its long-term support of this work. Thanks also to Aleda Freeman, Christian Jacqz, and the rest of the staff of MassGIS, to John Rader, formerly of MassGIS and USGS, and to Peter Steeves of USGS. These people worked together to prepare numerous digital data layers needed for measuring the basin characteristics used in the regression analyses, and to develop methods for automating measurements of the basin characteristics. The authors would also like to express their appreciation to the many other USGS employees who assisted with collection and analysis of streamflow data, measurements of basin characteristics, and preparation of this report.

\section{ESTIMATING METHODS FOR DATA-COLLECTION STATIONS}

The USGS operates three types of datacollection stations for which low-flow statistics can be estimated. These include (1) streamgaging stations, (2) low-flow partial record (or LFPR) stations, and (3) miscellaneous-measurement stations. Methods used to estimate streamflow statistics at datacollection stations differ depending on the type of statistic and on the type of station. Continuous records of streamflow are obtained at streamgaging stations. Streamflow statistics generally are determined directly from the records for these stations using methods described in the section "Low-flow statistics for streamgaging stations."

Low-flow partial-record and miscellaneousmeasurement stations are often established where streamflow information is needed, but either (1) it is not physically or economically feasible to continuously monitor streamflows at the location, or (2) the amount or accuracy of the streamflow information needed does not require continuous monitoring at the location. At LFPR stations, a series of streamflow measurements are made during independent low-flow periods when all or nearly all streamflow is from ground-water discharge. Usually about 10 low-flow measurements are obtained systematically over a period of years. Ries (1999) summarized a network of LFPR stations operated in Massachusetts during 1989 through 1996 as part of the three Basin Yield projects. Data for many of the network stations are used in the analyses described here.

Miscellaneous-measurement stations usually are established to obtain streamflow data for hydrologic studies of limited regional extent and short duration. The number and streamflow range of measurements made at these stations varies depending on the objectives of the study. High-flow as well as low-flow measurements commonly are made at miscellaneousmeasurement stations. Low-flow statistics can be estimated for miscellaneous-measurement stations when the number and range of low-flow measurements collected at the stations approximates the requirements for measurements at a LFPR station.

Many stations in Massachusetts have been operated at different times as both LFPR stations and miscellaneous-measurement stations. Methods used in this study to estimate low-flow statistics for LFPR stations and miscellaneous-measurement stations were the same and are described in the section "Low-flow statistics for low-flow partial-record stations." Because the data and analysis methods were the same, both station types are referred to as LFPR stations for the remainder of this report.

\section{Low-Flow Statistics for Streamgaging Stations}

Daily mean flows for all complete climatic years of record are used to determine flow-duration and low-flow frequency statistics for streamgaging stations. A climatic year begins on April 1 of the year noted and ends on March 31 of the following year. Daily mean flows for all complete Augusts for the period of record are used to determine August median flows. Daily mean flows for USGS streamgaging stations in Massachusetts can be obtained by downloading them from the World Wide Web address: http://waterdata.usgs.gov/nwis-w/MA/, or by contacting the Massachusetts-Rhode Island District information officer at the address provided on the back of the title page of this report.

The USGS has established standard methods for estimating flow-duration (Searcy, 1959) and low-flow frequency statistics (Riggs, 1972) for streamgaging stations. The computer software programs IOWDM, ANNIE, and SWSTAT can be used 
to format input data, manage and display data, and complete the statistical analyses, respectively, required to determine flow-duration and low-flow frequency statistics for streamgaging stations (Lumb and others, 1990; Flynn and others, 1995). These programs can be downloaded from the World Wide Web address: http://water.usgs.gov/software/surface_water.html.

\section{Flow-Duration Statistics}

A flow-duration curve is a graphical representation of the percentage of time streamflows for a given time step (usually daily) are equaled or exceeded over a specified period (usually the complete period of record) at a stream site. Flowduration curves usually are constructed by first ranking all of the daily mean discharges for the period of record at a gaging station from largest to smallest, next computing the probability for each value of being equaled or exceeded, then plotting the discharges against their associated exceedance probabilities (Loaiciga, 1989, p. 82). The daily mean discharges are not fit to an assumed distribution. Flow-duration analysis can be done by use of the USGS software described above or by use of most commercially available statistical software.

Flow-duration statistics are points along a flowduration curve. For example, the 99-percent duration streamflow is equaled or exceeded 99 percent of the time, whereas the 50-percent duration streamflow is equaled or exceeded 50 percent of the time. Strictly interpreted, flow-duration statistics reflect only the period for which they are calculated; however, when the period of record used to compute the statistics is sufficiently long, the statistics often are used as an indicator of probable future conditions (Searcy, 1959).

Vogel and Fennessey (1994) presented an alternative method for determining flow-duration statistics that indicate future conditions. This method requires determining flow-duration statistics for each individual year of record at a gaging station, then using the median of the annual values to represent the longterm flow-duration statistics. Median annual flowduration statistics determined by use of this alternative method tend to be higher than those calculated from the entire period of record by use of the traditional approach. The advantages of using the alternative method over the traditional approach are that confidence intervals can easily be attached to the statistics and probabilities of recurrence (recurrence intervals) of individual annual values can be analyzed. A disadvantage of the approach is that generally at least 10 years of record are needed to determine the statistics with reasonable confidence.

\section{Low-Flow Frequency Statistics}

Low-flow frequency statistics are determined for streamgaging stations from series of annual minimum mean flows for a given number of days. The statistics can be computed for any combination of days of minimum mean flow and years of recurrence. For example, the 7-day, 10-year low flow is determined from the annual series of minimum 7-day mean flows at a station. The mean flow for each consecutive 7-day period is computed from the daily records, and the lowest mean value for each year represents that year in the annual series. The 7-day minimum mean flows are usually fit to a log-Pearson Type III distribution to determine the recurrence interval for an individual 7-day minimum mean flow (Riggs, 1972), although other researchers sometimes have used other distributions (Vogel and Kroll, 1989). The value that recurs, on average, once in 10 years is the 7-day, 10-year low flow. The 7-day, 10-year low flow is used by the U.S. Environmental Protection Agency and by many state and local agencies to regulate waste-water discharges into surface waters.

The USGS has, to a large extent, automated the process of determining low-flow frequency statistics for streamgaging stations. The computer program SWSTAT (Lumb and others, 1990, p. 141) determines the annual series of minimum mean flows, ranks them, fits them to a log-Pearson type III distribution, and plots the resulting line of fit through the annual values. How well the data fit the distribution, and the ultimate low-flow frequency values to be used, are left to the judgment of the individual hydrologist. Usually at least 10 years of record are needed to determine the statistics with reasonable confidence. The annual series should be checked for trends, and corrected if necessary, before the log-Pearson analysis is done. The output from the analysis should be checked for outliers, and corrected if necessary, before the frequency curve is finalized. 


\section{August Median Flows}

August median flows at streamgaging stations can be determined by two methods. The U.S. Fish and Wildlife Service (USFWS) (1981) recommends calculating August median streamflows as the median value of the annual series of August monthly mean streamflows for the period of record at a gaging station. The USFWS uses the August median flow calculated in this manner as the minimum streamflow required for summertime maintenance of habitat for biota in New England streams.

Charles Ritzi and Associates (1987) suggested calculating August median flows as the median of the daily mean flows for all complete Augusts during the period of record at a streamgaging station. Kulik (1990) and Ries (1997) also used this method for calculating August median flows. This method typically results in values of August median flows that are somewhat lower than those determined by use of the method suggested by the USFWS. The monthly mean values used by the USFWS to calculate August median flows tend to be skewed by infrequent storm events that cause the monthly means to be larger than the medians, thus "the median is a more useful statistic than the mean for describing the central tendency" of the daily data (Kulik, 1990).

\section{Streamflow Statistics for Streamgaging Stations with Short Records}

Streamflow statistics are often needed for streamgaging stations with short records that may not reflect long-term conditions, and thus may not be useful as indicators of future conditions. Streamflow record extension or augmentation can be used to adjust the records for these stations to reflect a longer period. This is usually done by developing a relation between the daily mean streamflows or the streamflow statistics at the short-term station and the daily mean streamflows or the streamflow statistics for the same period at a nearby and hydrologically similar gaging station with a long record.

Vogel and Kroll (1991) demonstrated the value of augmenting streamflow records to obtain improved estimates of low- and peak-flow frequency statistics for streamgaging stations. They also described methods that can be used for augmenting records to estimate these statistics. Searcy (1959, p.12-14) and Ries (1994a, p. 21-22) described methods that can be used to extend the records for short-term streamgaging stations to estimate flow-duration statistics that reflect long-term conditions for the stations. These methods are similar to those described below for estimating low-flow statistics for LFPR stations.

\section{Low-Flow Statistics for Low-Flow Partial-Record Stations}

Streamflow statistics for LFPR stations are estimated by relating the low streamflow measurements made at the stations to daily mean discharges on the same days at nearby, hydrologically similar streamgaging stations. Lines or curves of correlation are developed between the same-day discharges at the LFPR stations and the selected streamgaging stations, and then the streamflow. statistics for the gaging stations are entered into the relations to determine the corresponding streamflow statistics for the LFPR stations. A mathematical correlation method described by Hirsch (1982) is used when the relations are linear. A graphical correlation method described by Riggs (1972) and Searcy (1959) is used when the relations are nonlinear. These methods were recommended for use by the USGS Office of Surface Water in Technical Memorandum No. 86.02, LowFlow Frequency Estimation at Partial-Record Sites, issued December 16, 1985. Both methods assume that the relation between the discharges at the LFPR station and the streamgaging station remains constant with time, thus the relation between the same-day flows can be used to estimate streamflow statistics that represent long-term conditions.

Medium- to high-range streamflow measurements made at some LFPR stations can be useful for estimating flow statistics near the median flow. Commonly, however, measurements made in these ranges need to be excluded from the analyses because the measurements were made at times when flow was rapidly changing, thus the measurements correlate poorly with same-day mean flows at gaging stations.

\section{Mathematical Method}

A mathematical record-extension method known as the Maintenance Of Variance Extension, Type 1 (MOVE.1) method (Hirsch, 1982) can be used to estimate streamflow statistics for LFPR stations when the relation between the logarithms of the same-day 
discharges at the LFPR station and a nearby gaging station is linear. The method is applied by first calculating logarithms-base 10 of the same-day flows for the LFPR and gaging stations and graphing the values to ascertain the linearity of the relation. The correlation coefficient is also computed as an indicator of linearity. If the relation appears linear, the MOVE.1 method is used; if not, a graphical method is used, as explained below.

When the graph of the data appears linear, the means $(\bar{Y}$ and $\bar{X})$ and standard deviations $\left(s_{y}\right.$ and $\left.s_{x}\right)$ of the logarithms-base 10 of the same-day flows for the LFPR and gaging stations and the logarithms-base 10 of the streamflow statistics $\left(X_{i}\right)$ for the gaging station are calculated. Estimates of the streamflow statistics $\left(\hat{Y}_{i}\right.$ ) for the LFPR station are obtained by inserting the calculated values into the MOVE. 1 equation:

$$
\hat{Y}_{i}=\bar{Y}+\frac{s_{y}}{s_{x}}\left(X_{i}-\bar{X}\right)
$$

and then retransforming the estimates by exponentiating the values $\left(10^{\hat{Y}_{i}}\right)$ to convert the estimates into their original units of measurement.

The MOVE. 1 relation between an LFPR station, Hemlock Brook near Williamstown, Mass., and a streamgaging station, Green River at Williamstown, Mass., is shown as an example in figure 2. The line through the data points was determined by inserting the same-day flows for the gaging station into the MOVE.1 equation as the $X_{i}$ values to obtain estimated same-day flows for the LFPR station, then connecting the points to illustrate how the MOVE.1 estimates fit the original data.

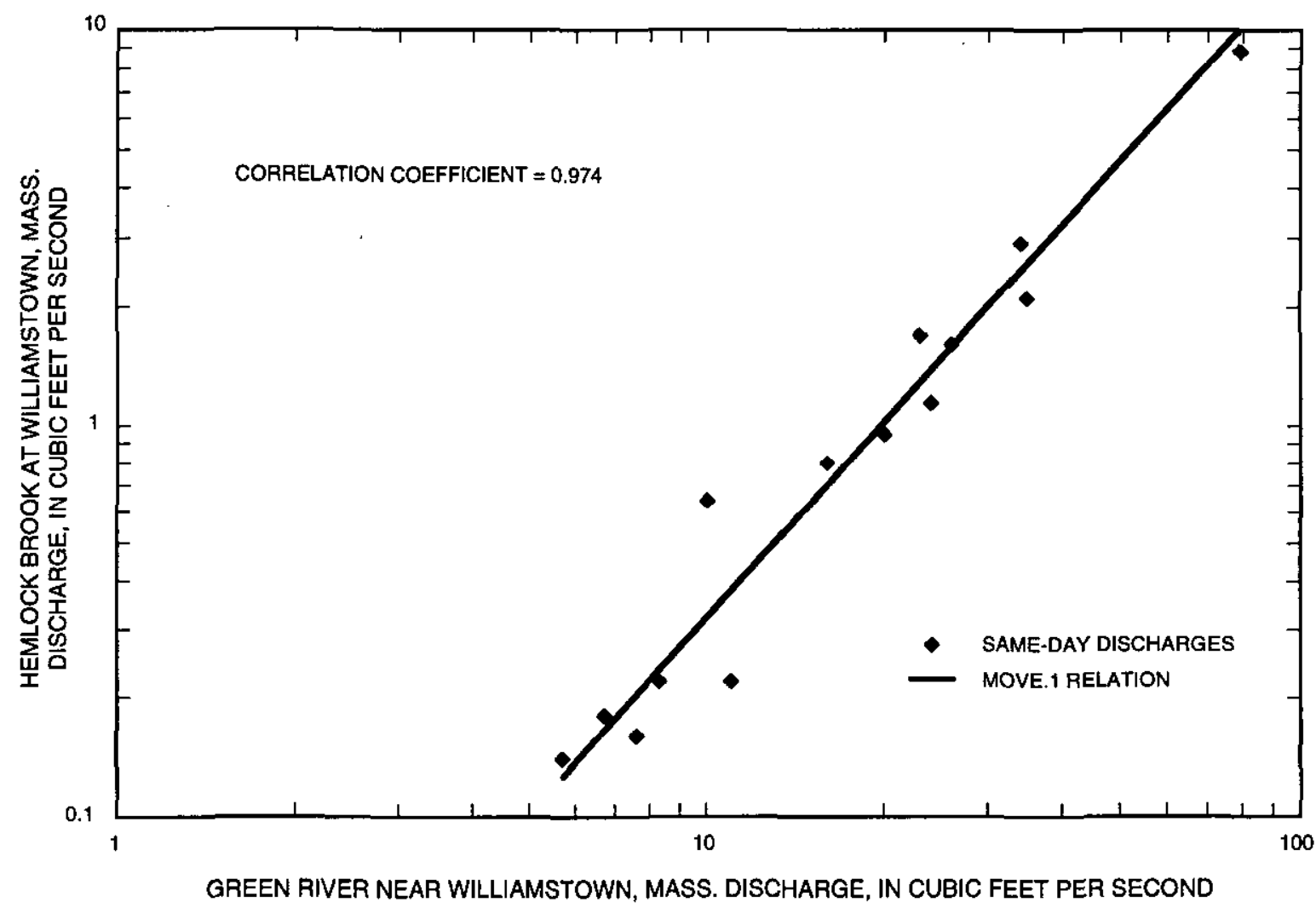

Figure 2. Example MOVE.1 relation between a low-flow partial-record station, Hemlock Brook near Williamstown, Mass., and a streamgaging station, Green River at Williamstown, Mass. 


\section{Graphical Method}

The graphical method (Searcy, 1959; Riggs, 1972 ) is used when curvature is apparent in the plot of logarithms-base 10 of the same-day flows. The method is applied by first plotting the original (non-log) values of the same-day flows on log-log paper and drawing a smooth curve through the plotted points that appears to best fit the data. Next, the calculated streamflow statistics for the gaging station are entered into the curve of relation and corresponding values for the LFPR station are read from the graph. Log-log plots sometimes have extreme curvature in the very low end of the relation. Because of this, it is sometimes necessary to replot the data on arithmetic paper to adequately define the relation in this range and to avoid long downward extrapolations that would otherwise be necessary with log-log plots.

The graphical relation between an LFPR station, Hopping Brook near West Medway, Mass., and a streamgaging station, West River near Uxbridge, Mass., is shown as an example in figure 3. The curve was fit through the data visually to minimize overall differences between the observed and fit values.

\section{Combining Estimates Determined from Multiple Index Sites}

Selection of individual gaging stations for relation to a LFPR station is based on distance between the stations and similarity of basin characteristics between the stations. In Massachusetts, the measured streamflows at a LFPR station usually will correlate well with more than one gaging station. When this happens, MOVE.1 or graphical relations between a given LFPR station and each of several gaging stations can be developed to estimate the streamflow statistics for the LFPR station. This process results in multiple estimates of the streamflow statistics for a single LFPR station, when only a single best estimate is desired.

Tasker (1975) stated that when independent multiple estimates of streamflow statistics are available for a single station, the best estimate can be obtained by weighting each individual estimate by its variance and averaging the weighted estimates. This final weighted estimate is best because its variance is less than or equal to the variances of each of the individual estimates.

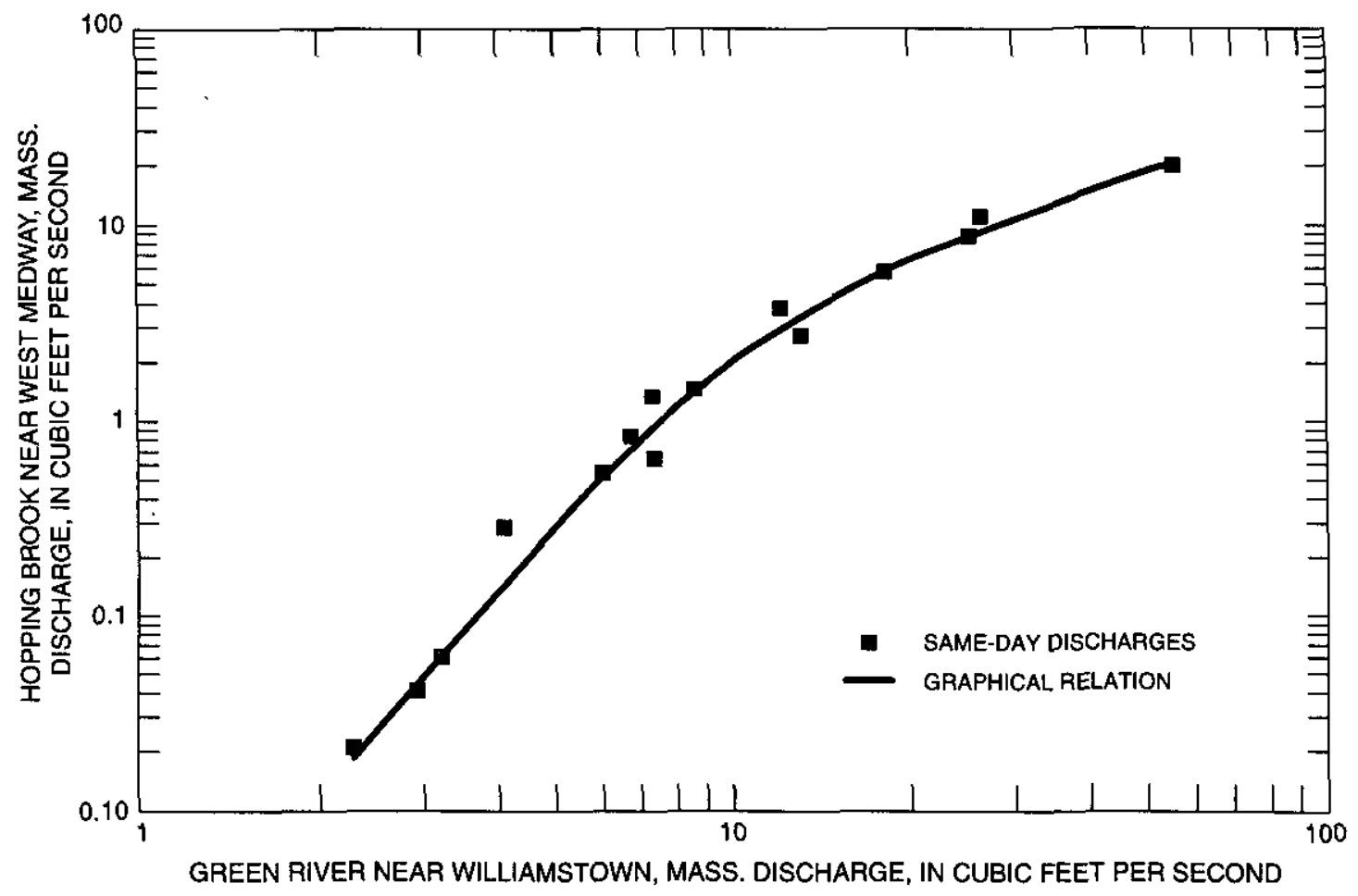

Figure 3. Example graphical relation between a low-flow partial-record station, Hopping Brook near West Medway, Mass., and a streamgaging station, West River near Uxbridge, Mass. 
Calculated variances for each individual estimate of the streamflow statistics for each LFPR station were needed to obtain the final best estimates for the stations. Variances were calculated by use of the equation

$$
\begin{aligned}
V_{S, U}=\frac{V_{R}}{M}\left[1+\frac{1}{M-3}\right. & \left.+\frac{z^{2} M}{M-3}+\left(\frac{S E_{S, G}}{s_{B, G}}\right)^{2}\left(\frac{M}{M-3}\right)\right] \\
& +b^{2} V_{S, G},
\end{aligned}
$$

where:

$V_{S, U}$ is the sample variance of the streamflow statistic at the LFPR station, in log units;

$V_{S, G}$ is the sample variance of the streamflow statistic at the gaging station, in log units;

$V_{R}$ is the variance about the MOVE.1 or graphical line of relation;

$M$ is the number of base-flow measurements;

$S E_{S, G}$ is the standard error of the streamflow statistic at the gaging station, which equals the square root of $V_{S, G}$;

$b$ is computed as $r\left(s_{B, U} / s_{B, G}\right)$, where $r$ is the correlation coefficient between the low streamflow measurements made at the LFPR station and the same-day mean discharges at the gaging station (the value of $r$ can be set to 1 when MOVE. 1 is used to obtain the estimate), and $s_{B, U}$ is the standard deviation of the logarithms-base 10 of the low streamflow measurements made at the LFPR station;

$s_{B, G}$ is the standard deviation of the logarithms-base 10 of the mean discharges at the gaging station on the same days the low-flow measurements were made at the ungaged site; and

$z$ is the number of standard deviation units between the mean of the logarithms-base 10 of the same-day mean discharges at the gaging station and the logarithm-base 10 of the streamflow statistic at the gaging station.

Equation 2 is modified from an equation developed by Hardison and Moss (1972) to determine the variance of estimates of 7-day, T-year low flows obtained from an ordinary-least-squares (OLS) regression of the logarithms-base 10 of base-flow measurements at a LFPR station to the logarithms-base 10 of same-day mean discharges at a nearby, hydrologically similar gaging station. Modifications to the Hardison and Moss equation were needed to generalize its use for other streamflow statistics and to allow for the MOVE. 1 or graphical methods of line fitting to be used rather than the ordinary-least-squares method of line fitting. Assumptions for use of equation 2 are generalized from Hardison and Moss (1972):

1. The true relation between the logarithms of the base-flow measurements at the LFPR station and the same-day mean streamflows at the gaging station is the same as the true relation between the logarithms of the data from which the low streamflow statistics are calculated. In the case of the 7-day low-flow statistics, the data are calculated from an annual series of minimum 7-day mean flows. In the case of the flow-duration and August median statistics, the data are calculated from the daily mean flows.

2. The relation between the logarithms of the data from which the low-flow statistics are calculated is the same as the relation between the flow statistics for the stations.

3. The time-sampling errors in the streamflow statistics that are used to enter the regression equation are independent of the variation in the base-flow measurements used to define the equation.

4. The logarithms of the measured streamflows at the LFPR station and the same-day mean streamflows at the gaging station follow a bivariate normal distribution.

5. The $M$ measurements made at the LFPR station are statistically independent estimates of the base-flow relation.

Hardison and Moss noted that the first four assumptions appeared to be reasonable under the conditions in which application of the original equation 2 was intended. These assumptions are reasonable for the modified equation 2 as well. Hardison and Moss also noted that assumption 5 could be satisfied by applying criteria for using only those measurements that can be reasonably assumed independent to define the relation. The criterion usually applied is that the base-flow measurements used in the relation should be separated by significant storm events (Stedinger and Thomas, 1985). Collection of low streamflow measurements at LFPR stations in Massachusetts has generally followed that criterion. 
When estimates are obtained for LFPR stations from relations with more than one streamflow-gaging station, the individual estimates, $Q_{s, U_{i}}$, (where $i=1$, $\ldots, n$, and $n$ is the number of individual estimates of statistic $S$ for LFPR station $U$ ) can be weighted by the reciprocals of their variances, determined from equation 2, to obtain minimum-variance estimates, $Q_{S, U_{w}}$, for each of the statistics from the equation

$$
Q_{S, U_{w}}=\frac{\sum_{i=1}^{n}\left(Q_{S, U_{i}} / V_{S, U_{i}}\right)}{\sum_{i=1}^{n}\left(1 / V_{S, U_{i}}\right)} .
$$

Weighted variances, $V_{S, U}$, can be determined for the weighted estimates from the equation

$$
V_{S, U_{w}}=1 / \sum_{i=1}^{n}\left(1 / V_{S, U_{i}}\right) .
$$

Standard errors, $S E_{S, U}$, in percent, for the weighted estimates can be obtained from the equation (Stedinger and Thomas, 1985 , p. 18)

$$
S E_{S, U_{w}}=100 \sqrt{\exp \left(5.3018 V_{w}\right)-1} .
$$

Equation 2 does not account for errors inherent in the discharge measurements made at the LFPR station or in the mean daily discharges determined for the gaging stations. In addition, the estimates obtained for an LFPR station by use of the MOVE.1 or graphical method with multiple gaging stations are not truly independent because of cross correlation of the streamflow records at the gaging stations. As a result, the final estimates obtained using equations 2 and 3 may not truly be the best possible, and the true variances and standard errors are somewhat larger than those obtained using equations 4 and 5 .

The equivalent years of record also can be computed for estimates of streamflow statistics for the LFPR stations. The equivalent years of record is the length of time that a streamgaging station would need to be operated at the location of the LFPR station to obtain an estimate of the streamflow statistic with equal accuracy. The equivalent years of record for LFPR stations is computed from an equation developed by combining equations 7, 8, and 9 in Hardison and Moss (1972) and solving for the number of years of record. The resulting equation is:

$$
\begin{aligned}
& N_{U}=\left(R_{S}^{2} I_{S, G}^{2} k^{2}\left(\frac{s_{B, U}}{s_{B, G}}\right)^{2}\right) \\
& /\left(\frac{V_{R}}{M}\left(\frac{1+z^{2}}{K}\right)+\frac{b^{2} R_{S}^{2} I_{S, G}^{2}}{N_{G}}\right),
\end{aligned}
$$

where all variables are as previously defined, and:

$N_{U}$ is the equivalent years of record at the partialrecord station;

$N_{G}$ is the years of record at the streamflow-gaging station used in the relation;

$I_{S, G}$ is the standard deviation of the logarithms-base 10 of the observed flows (annual series for frequency statistics or daily flows for duration statistics) at the streamflow-gaging station

$k$ is from equation 9 of Hardison and Moss (1972),

$$
k=\sqrt{r^{2}+\left(\frac{M-4}{M-2}\right)\left(1-r^{2}\right)} ; \text { and }
$$

$K$ is from equation 3 of Hardison and Moss (1972),

$$
\begin{gathered}
K=\left(1+z^{2}\right) \\
/\left[1+\frac{1}{M-3}+\frac{z^{2} M}{M-3}+\left(\frac{{ }^{S E} S, G}{{ }^{s} B, G}\right)^{2}\left(\frac{M}{M-3}\right)\right]
\end{gathered}
$$

$R_{S}$ is a correction factor that depends on the streamflow statistic being estimated, and is determined by combining the equation that appears in table 1 of Hardison and Moss (1972),

$$
R_{S}=\left(S E_{S, G} \sqrt{N}\right) / I_{S, G},
$$

with the equation

$$
S E_{S, G}=I_{S, G} \sqrt{\frac{1+k_{S}^{2} / 2}{N}}
$$

from Hardison (1969, p. D212) to obtain

$$
R_{S}^{2}=1+k_{S}^{2} / 2 .
$$

Subscripts have been changed from their original appearance in equations 6 to 11 to generalize from T-year statistics to other streamflow statistics. In equations 10 and 11 above, $k_{S}$ is the number of 
standard deviation units between the streamflow statistic and the mean of the data from which it is calculated. From assumption 4 above, the annual series of 7-day low flows and the daily mean streamflows from which the flow-duration statistics and the August median streamflows are calculated are distributed lognormally, and thus $k_{S}$ can be obtained from a table of standard normal deviates as appears in most statistical textbooks. Values for the 99-, 98-, 95-, 90-, 85-, 80-, 75-, 70-, 60-, and 50-percent duration streamflows, the August median streamflow, and the 7-day, 10- and 2-year streamflows are 2.3263, 2.0537, 1.6449, 1.2816, $1.0364,0.8416,0.6745,0.5244,0.2533,0.0,0.0$, 1.2816 , and 0.0 , respectively (Iman and Conover, 1983, p. 434-435). When estimates for LFPR stations are obtained from relations with more than one streamgaging station, the individual calculations of equivalent years of record can be weighted by the reciprocals of the variances of the estimated streamflow statistics, determined from equation 2 , then the individual weighted equivalent years of record can be averaged to obtain the final weighted equivalent years of record for the LFPR station by substituting the. equivalent years of record estimates for the discharge estimates in equation 3 above.

\section{ESTIMATING METHODS FOR UNGAGED STREAM SITES}

Estimates of streamflow statistics often are needed for sites on streams where no data are available. The two methods used most commonly to estimate statistics for ungaged sites are the drainage-area ratio method and regression equations. The drainage-area ratio method is most appropriate for use when the ungaged site is near a streamgaging station on the same stream (nested). Regression equations can be used to obtain estimates for most ungaged sites. Additional details on application of these methods is provided below.

\section{Drainage-Area Ratio Method}

The drainage-area ratio method assumes that the streamflow at an ungaged site is the same per unit area as that at a nearby, hydrologically similar streamgaging station used as an index. Drainage areas for the ungaged site and the index station are determined from topographic maps. Streamflow statistics are computed for the index station, then the statistics (numerical values) are divided by the drainage area to determine streamflows per unit area at the index station. These values are multiplied by the drainage area at the ungaged site to obtain estimated statistics for the site. This method is most commonly applied when the index gaging station is on the same stream as the ungaged site because the accuracy of the method depends on the proximity of the two, on similarities in drainage area and on other physical and climatic characteristics of their drainage basins.

Several researchers have provided guidelines as to how large the difference in drainage areas can be . before use of regression equations is preferred over use of the drainage-area ratio method. Guidelines have been provided for estimating peak-flow statistics, and usually the recommendation has been that the drainage area for the ungaged site should be within 0.5 and 1.5 times the drainage area of the index station (Choquette, 1988, p. 41; Koltun and Roberts, 1990, p. 6; Lumia, 1991, p. 34; Bisese, 1995, p. 13). One report (Koltun and Schwartz, 1986, p.32) recommended a range of 0.85 to 1.15 times the drainage area of the index station for estimating low flows at ungaged sites in Ohio. None of these researchers provided any scientific basis for use of these guidelines. R.E. Thompson, Jr. (U.S. Geological Survey, written commun., 1999), however, recently completed a study that provides evidence supporting use of ratios between 0.33 and 3.0 for streams in Pennsylvania.

Because of uncertainty in an appropriate range for use of the drainage-area ratio method for streams in Massachusetts, an experiment was designed to determine the ratio range in which the method is likely to provide better estimates of low streamflow statistics than use of regression equations. Five river basins with one or more continuous gaging stations in each basin were chosen for the experiment to represent the varied topography, geology, and precipitation of Massachusetts. Two basins, the Green and the West Branch Westfield, are in the mountainous western part of the State; two basins, the Quaboag and the Squannacook, are in the foothills of the central part of the State; and one basin, the Wading, is in the flat, low-lying landscape typical of eastern Massachusetts.

A total of 25 LFPR stations were established upstream and downstream from 8 streamgaging stations in the 5 basins. Most of the LFPR stations have 
smaller drainage areas than those for the streamgaging stations because historically most streamgaging stations in Massachusetts have been established near the downstream ends of rivers. Locations and drainage boundaries for the streamgaging stations and LFPR stations are shown for each basin in figures $4 A$ to $4 E$. Station descriptions for the stations are in table 1.

Seven to ten discharge measurements were made at each of the LFPR stations during 1994 and 1995. The measurements were published in the Mass. annual data reports for those years (Gadoury and others, 1995; Socolow and others, 1996, 1997). The measurements, along with historical measurements available at three stations, were used to estimate streamflows at the 99-, 98-, and 95-percent durations and August median flows for the stations using the methods described above for LFPR stations. Estimates of the flow-duration statistics were also derived for the stations using the drainagearea ratio method and the regression equations developed by Ries (1994b, 1997). The regression equations presented later in this report were not used because they were not yet available at the time of the analysis.

Two gaging stations were available in some basins for the analysis (table 1). To increase the sample size for the analysis of the drainage-area ratio method, drainage-area ratio estimates and regression-equation estimates were determined for the streamgaging stations in addition to the estimates determined from the records for the stations. The drainage-area ratio estimates were determined for each streamgaging station by applying the flow per unit area for one streamgaging station to the drainage area for the other streamgaging station. The longest common period of record available for the streamgaging stations in each basin was used to compute the streamflow statistics for the analysis to avoid differences in the statistics due to differences in record length.

The Wading River Basin, unlike the other four basins used in the experiment, has water withdrawals and regulated streamflows in parts of the basin (see table 1, remarks). It was chosen for use in the experiment because the unregulated part of the basin is the largest unregulated area in southeastern Massachusetts. Discharges, drainage areas, and other basin characteristics used to solve the regression equations were adjusted for stations downstream from the diversions and regulation to correct for these activities. Of the seven stations (including one active and one discontinued streamgaging station) at which streamflow measurements were made in the Wading River Basin, only three of the stations $(01108490$, 01108600 , and 01108700) were used to compare results of the different estimation methods. Discharges and basin characteristics from stations 01108440 and 01108470 were subtracted from station 01108490 , and station 01108500 was subtracted from 01108700 to determine discharges and basin characteristics representative of the naturally flowing areas above those stations. The adjusted discharges and basin characteristics were used to estimate unregulated streamflow statistics for the stations. Station 01108600 was not affected by regulation or diversions.

The drainage area for the Wading River below the West Mansfield streamgaging station (station 01108500 ) and above the Norton streamgaging station (station 01109000 ) is not affected by regulation or diversions, whereas the drainage area above the West Mansfield station is affected by regulation and diversions. Streamflow statistics for the West Mansfield station were subtracted from those for the Norton station to obtain the streamflow statistics for the naturally flowing part of the drainage area above the Norton station.

The four streamflow statistics (99-, 98-, and 95-percent duration and August median streamflows) estimated by the three different methods (correlation, drainage-area ratio, and regression equation) for each of the LFPR and streamgaging stations used in the analysis are presented in table 7 (back of the report). The estimates derived by correlation, shown in the column labeled "Correlation method estimate or computed," were considered the best estimates available for the LFPR stations for the analysis, and they were compared to the estimates derived by the other methods. The correlation estimates were considered the best estimates because they were derived from actual streamflow data for the stations, whereas the drainage-area ratio and regression estimates were derived indirectly based on an assumed or statistical relation between the basin characteristics for the LFPR stations and streamgaging stations. Statistics shown for streamgaging stations in the column labeled "Correlation method estimate or computed" were computed from dailyflow records. 


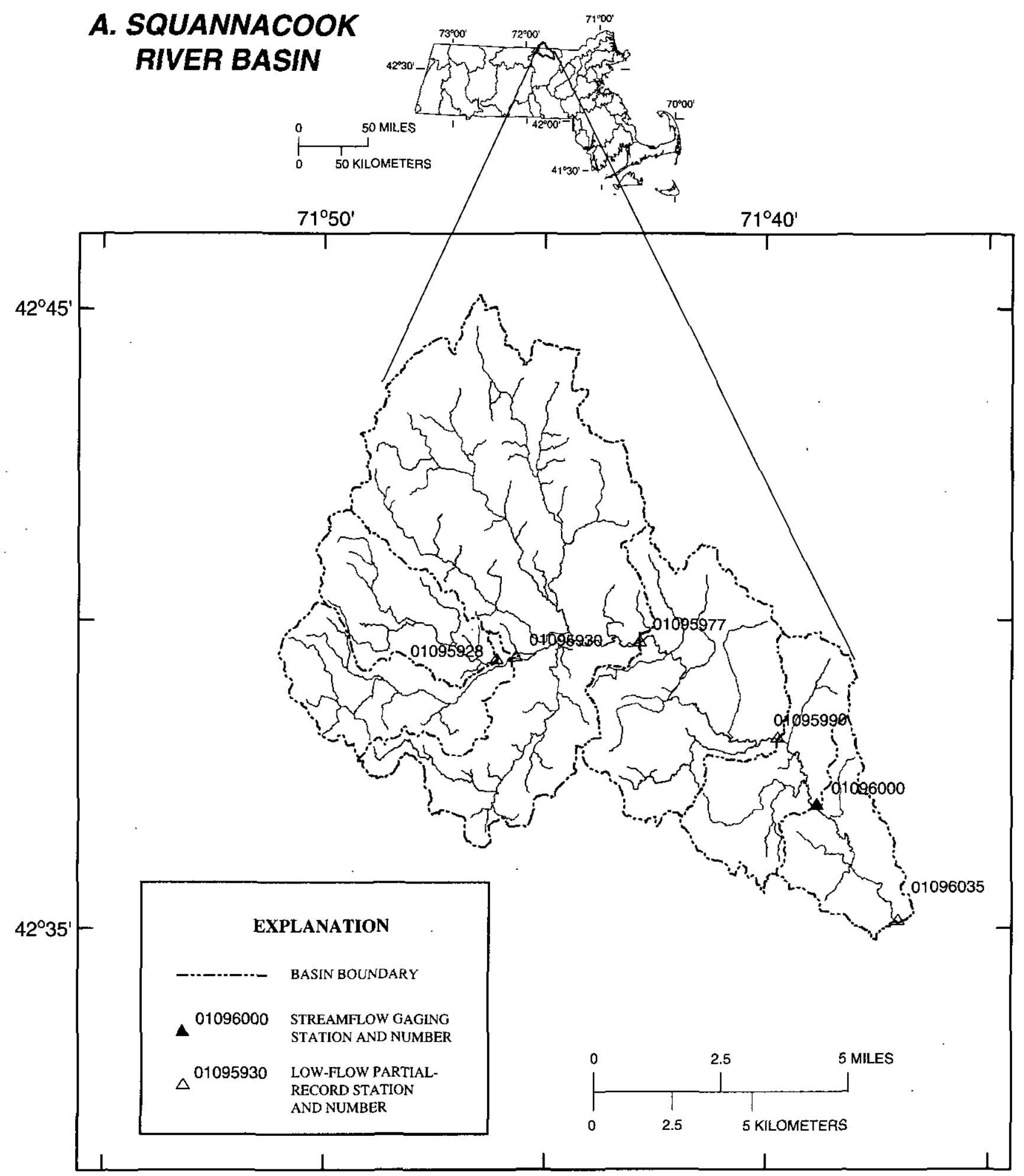

Figure 4. Locations and drainage boundaries of low-flow partial-record stations and gaging stations in the $(A)$ Squannacook, $(B)$ Wading, (C) Quaboag, $(D)$ Green, and $(E)$ West Branch Westfield River Basins, Massachusetts. 


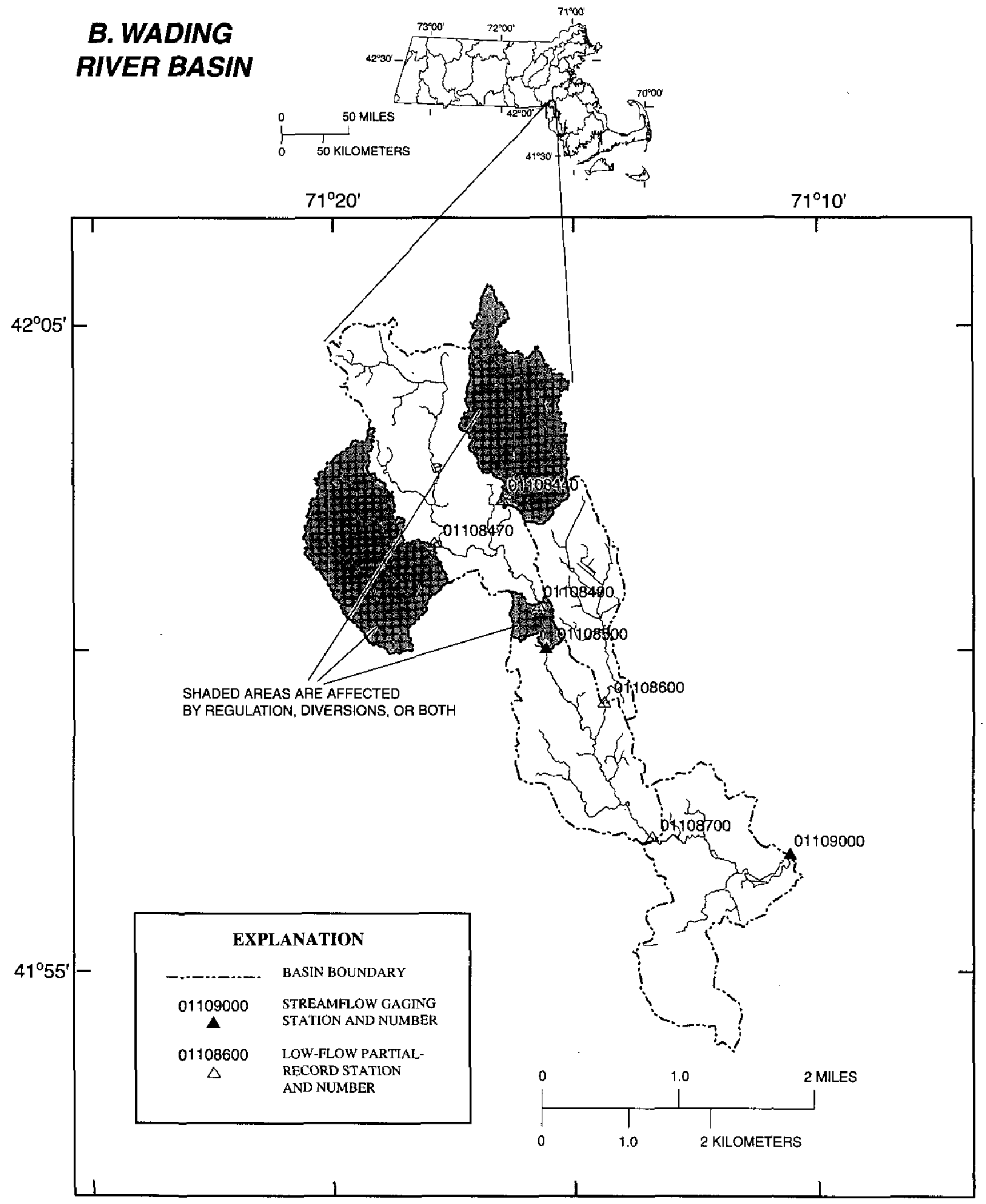

Figure 4. Locations and drainage boundaries of low-flow partial-record stations and gaging stations in the (A) Squannacook, $(B)$ Wading, $(C)$ Quaboag, $(D)$ Green, and $(E)$ West Branch Westfield River Basins, Massachusetts-Continued. 


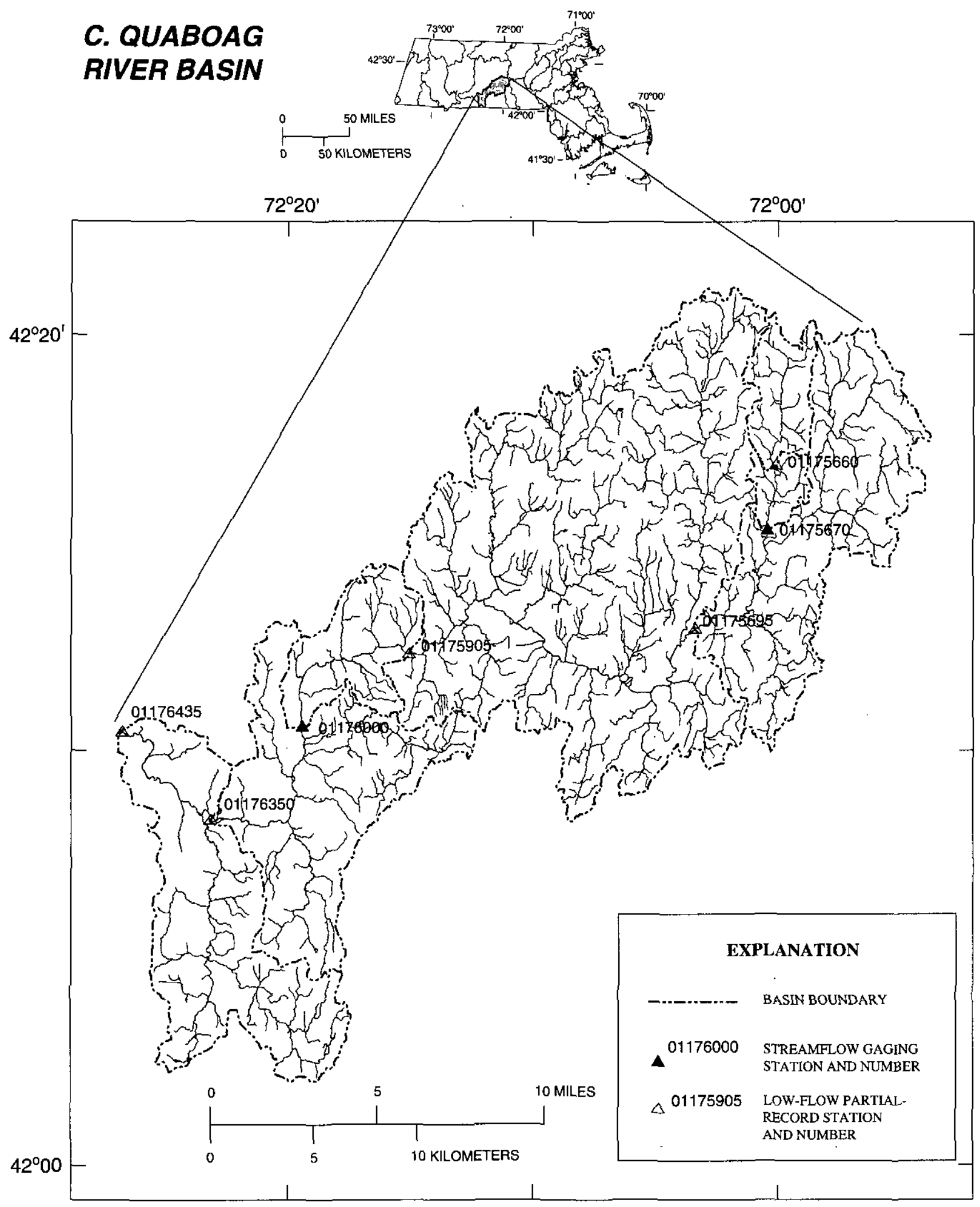

Figure 4. Locations and drainage boundaries of low-flow partial-record stations and gaging stations in the $(A)$ Squannacook, $(B)$ Wading, $(C)$ Quaboag, $(D)$ Green, and $(E)$ West Branch Westfield River Basins, Massachusetts-Continued. 


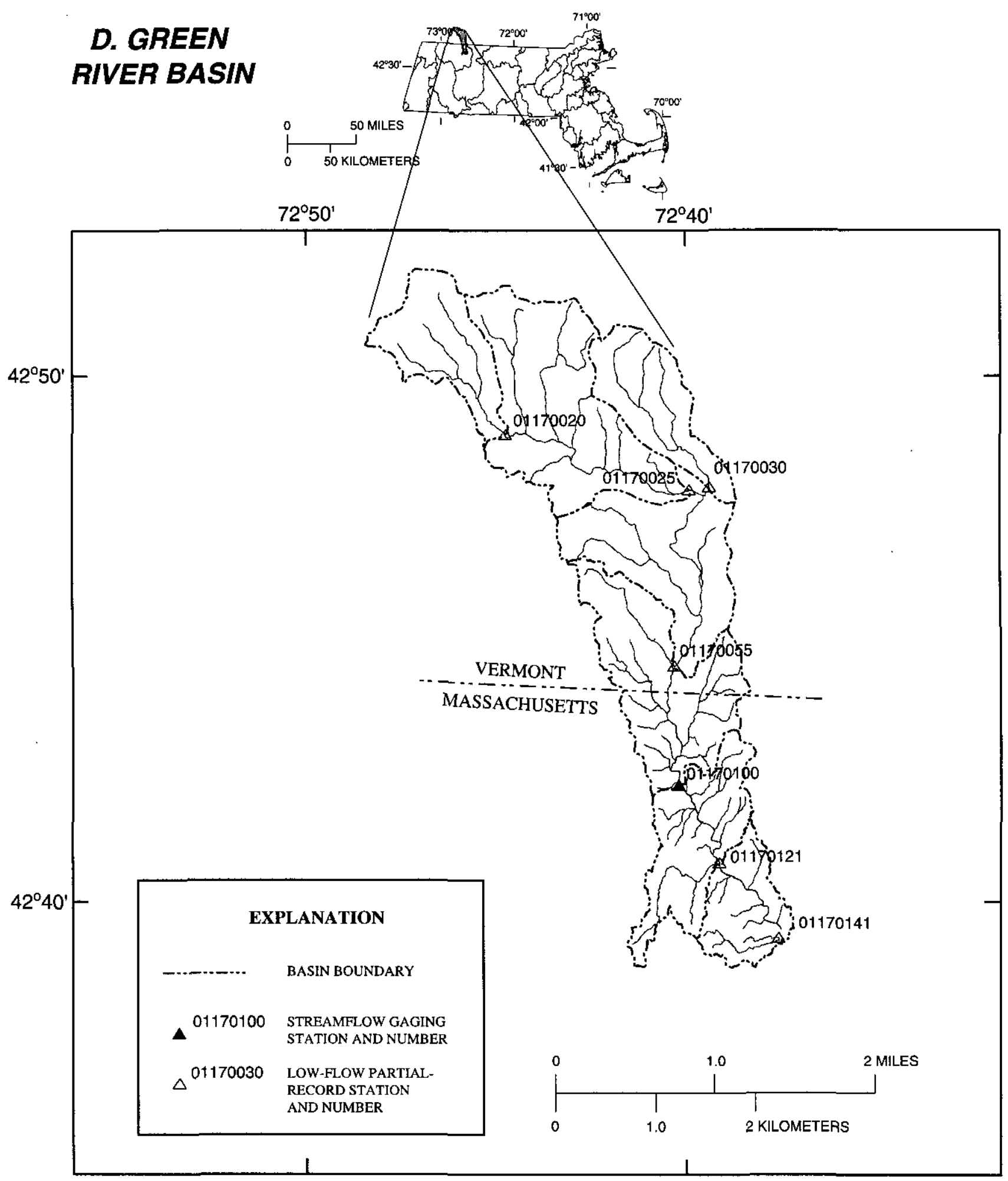

Figure 4. Locations and drainage boundaries of low-flow partial-record stations and gaging stations in the $(A)$ Squannacook, $(B)$ Wading, $(C)$ Quaboag, $(D)$ Green, and $(E)$ West Branch Westfield River Basins, MassachusettsContinued. 


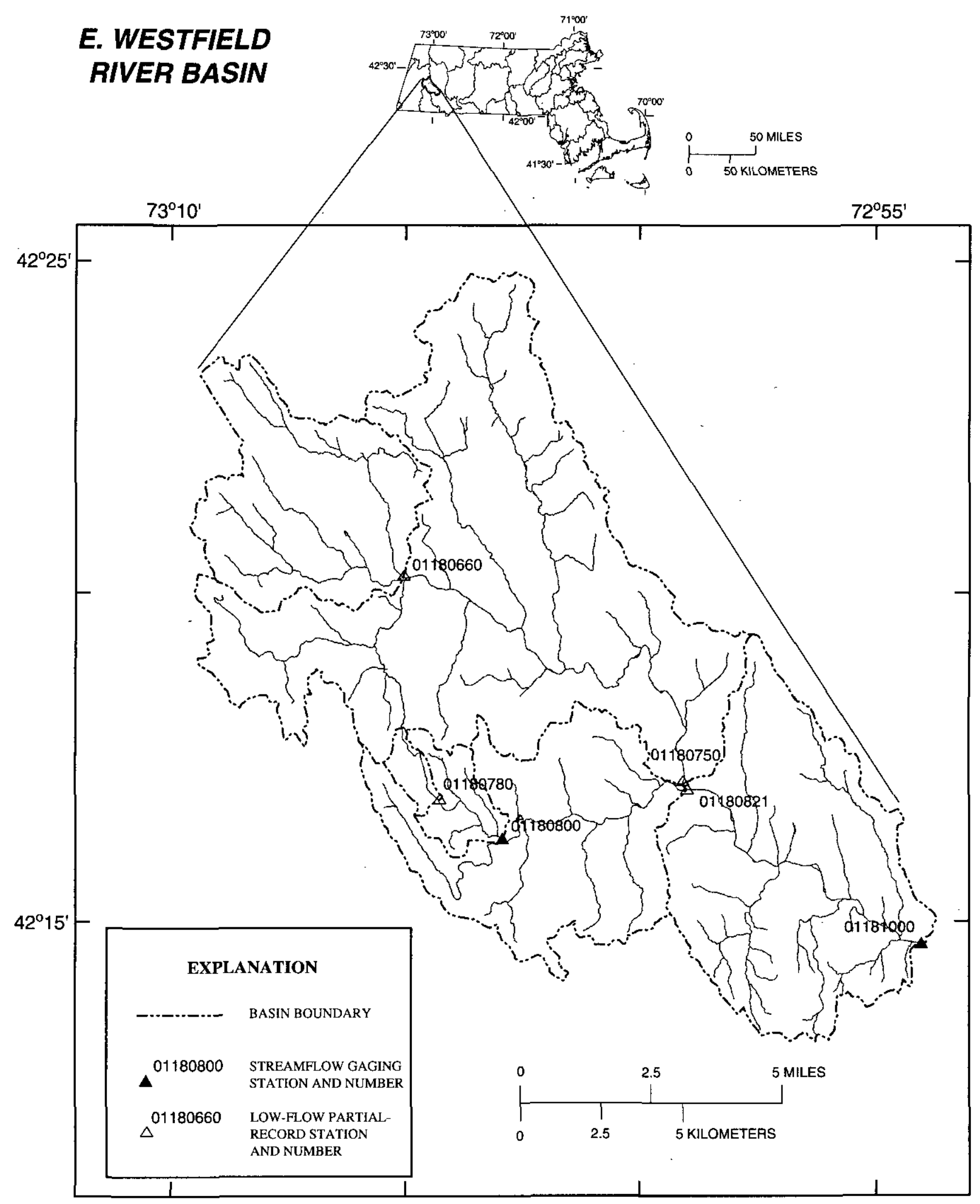

Figure 4. Locations and drainage boundaries of low-flow partial-record stations and gaging stations in the $(A)$ Squannacook, $(B)$ Wading, $(C)$ Quaboag, $(D)$ Green, and $(E)$ West Branch Westfield River Basins, Massachusetts-Continued. 
Table 1. Descriptions of low-tlow partial-record and streamgaging stations used to analyze the applicability of the drainage-area ratio method for estimating streamflow statistics for ungaged Massachusetts streams

[USGS station No.: Station numbers for streamgaging stations are in bold; all others are low-flow partial-record stations. Station name: All stations are in Massachusetts except as otherwise indicated. Areas are in square miles; lengths are in miles; elevations are in feet. Period of record: The word "present" refers to the year of publication for this report (2000). Region: 0 is eastern; 1 is western. No. number; USGS, U.S. Geological Survey; -- , no continuous data]

\begin{tabular}{cccccccc}
$\begin{array}{c}\text { USGS } \\
\text { station } \\
\text { No. }\end{array}$ & Latitude Longitude & Station name & $\begin{array}{c}\text { Period of Drain- } \\
\text { record age }\end{array}$ & $\begin{array}{c}\text { Total } \\
\text { stream } \\
\text { length }\end{array}$ & $\begin{array}{c}\text { Strati- } \\
\text { fied } \\
\text { drift } \\
\text { area }\end{array}$ & $\begin{array}{c}\text { Mean } \\
\text { basin } \\
\text { eleva- } \\
\text { tion }\end{array}$ & $\begin{array}{c}\text { Mini- } \\
\text { mum } \\
\text { basin } \\
\text { eleva- } \\
\text { tion }\end{array}$ \\
\hline
\end{tabular}

\begin{tabular}{|c|c|c|c|c|c|c|c|c|c|c|c|}
\hline \multicolumn{12}{|c|}{ Squannacook River Basin (subbasin of Nashua River Basin) } \\
\hline 01095928 & 424024 & 714639 & Trapfall Brook near Ashby & -- & 5.89 & 14.6 & 0.66 & 858 & 480 & 0 & \\
\hline 01095930 & 424027 & 714614 & Willard Brook near West Townsend & -- & 12.34 & 31.8 & 2.12 & 878 & 442 & 0 & \\
\hline 01095977 & 424041 & 714329 & $\begin{array}{l}\text { Squannacook River near West } \\
\text { Townsend }\end{array}$ & -- & 44.3 & 87.3 & 8.19 & 725 & 295 & 0 & \\
\hline 01095990 & 423908 & 714022 & $\begin{array}{l}\text { Squannacook River at Townsend } \\
\text { Harbor }\end{array}$ & -- & 57.6 & 119 & 13.8 & 649 & 262 & 0 & \\
\hline 01096000 & 423803 & 713930 & Squannacook River near West Groton & $\begin{array}{l}1950- \\
\text { present }\end{array}$ & 64.4 & 130 & 17.1 & 618 & 247 & 0 & $\begin{array}{l}\text { Occasional regulation by mill } \\
\text { upstream. }\end{array}$ \\
\hline 01096035 & 423607 & 713743 & $\begin{array}{c}\text { Squannacook River below State } \\
\text { Route } 225 \text { at West Groton }\end{array}$ & - & 69.9 & 139 & 19.6 & 595 & 224 & 0 & $\begin{array}{l}\text { Occasional regulation by mill } \\
\text { upstream. }\end{array}$ \\
\hline \multicolumn{12}{|c|}{ Wading River Basin (subbasin of Taunton River Basin) } \\
\hline 01108440 & 420218 & 711632 & $\begin{array}{l}\text { Wading River at West Street, near } \\
\text { South Foxboro }\end{array}$ & -- & 4.83 & 12.4 & 1.96 & 270 & 180 & 0 & $\begin{array}{l}\text { Regulation by lakes and ponds. } \\
\text { Diversions from basin for } \\
\text { municipal supplies. }\end{array}$ \\
\hline 01108470 & 420139 & 711757 & Hawthorne Brook at Shepardville & -- & 5.32 & 8.49 & 2.48 & 268 & 192 & 0 & $\begin{array}{l}\text { Regulation by lakes and ponds. } \\
\text { Diversions from basin for } \\
\text { municipal supplies. }\end{array}$ \\
\hline 01108490 & 420107 & 711602 & $\begin{array}{l}\text { Wading River at West Street, near } \\
\text { Mansfield }\end{array}$ & -- & 18.7 & 40.3 & 10.3 & 251 & 148 & 0 & $\begin{array}{l}\text { Natural flows for this station } \\
\text { obtained by subtracting flows } \\
\text { from } 01108440 \text { and } 01108470 .\end{array}$ \\
\hline 01108500 & 420000 & 711538 & Wading River at West Mansfield & $1954-86$ & 19.6 & 42.6 & 11.2 & 247 & 146 & 0 & $\begin{array}{l}\text { Regulation by lakes and ponds. } \\
\text { Diversions to and from basin for } \\
\text { municipal supplies. }\end{array}$ \\
\hline 01108600 & 415911 & 711427 & Hodges Brook at West Mansfield & -- & 3.83 & 8.37 & 2.49 & 175 & 128 & 0 & \\
\hline 01108700 & 415706 & 711327 & Wading River at Chartley & -- & 29.2 & 62.9 & 16.8 & 214 & 95 & 0 & $\begin{array}{l}\text { Natural flows for this station } \\
\text { obtained by subtracting flow } \\
\text { from } 01108500 .\end{array}$ \\
\hline 01109000 & 415651 & 711038 & Wading River near Norton & $\begin{array}{l}1926- \\
\text { present }\end{array}$ & 43.4 & 85.4 & 25.7 & 180 & 68 & 0 & $\begin{array}{l}\text { Natural flows for this station } \\
\text { obtained by subtracting flow } \\
\text { from } 01108500 \text {. }\end{array}$ \\
\hline
\end{tabular}


Table 1. Descriptions of low-flow partial-record and streamgaging stations used to analyze the applicability of the drainage-area ratio method for estimating streamilow statistics for ungaged Massachusetts streams--Continued

\begin{tabular}{|c|c|c|c|c|c|c|c|c|c|c|c|}
\hline $\begin{array}{c}\text { USGS } \\
\text { station } \\
\text { No. }\end{array}$ & $\begin{array}{c}\text { Latitude } \\
\text {.." }\end{array}$ & Longitude & Station name & $\begin{array}{l}\text { Period of } \\
\text { record }\end{array}$ & $\begin{array}{c}\text { Drain- } \\
\text { age } \\
\text { area }\end{array}$ & $\begin{array}{l}\text { Total } \\
\text { stream } \\
\text { length }\end{array}$ & $\begin{array}{l}\text { Strati- } \\
\text { fied } \\
\text { drift } \\
\text { area }\end{array}$ & $\begin{array}{c}\text { Mean } \\
\text { basin } \\
\text { eleva- } \\
\text { tion }\end{array}$ & $\begin{array}{c}\text { Mini- } \\
\text { mum } \\
\text { basin } \\
\text { eleva- } \\
\text { tion }\end{array}$ & Region & Remarks \\
\hline
\end{tabular}

Green River Basin (subbasin of Deerfield River Basin)

\begin{tabular}{|c|c|c|c|c|c|c|c|c|c|c|c|}
\hline 01170020 & 424851 & 724453 & Green River at Harrisville, Vt. & -- & 5.18 & 9.60 & 0.30 & 1,790 & 1,450 & 1 & \\
\hline 01170025 & 424743 & 723952 & Green River at West Guilford, Vt. & -- & 16.9 & 34.4 & 0.66 & 1,610 & 899 & 1 & \\
\hline 01170030 & 424754 & 723933 & $\begin{array}{l}\text { Hinesburg Brook at West } \\
\text { Guilford, Vt. }\end{array}$ & -- & 5.79 & 10.8 & 0.11 & 1,520 & 899 & 1 & \\
\hline 01170055 & 424427 & 724027 & $\begin{array}{l}\text { Green River above Roaring Brook } \\
\text { near Green River, Vt. }\end{array}$ & -- & 31.8 & 61.6 & 1.23 & 1,470 & 597 & 1 & \\
\hline 01170100 & 424212 & 724016 & Green River near Colrain & $\begin{array}{l}1968- \\
\text { present }\end{array}$ & 41.3 & 83.8 & 1.48 & 1,360 & 499 & 1 & \\
\hline 01170121 & 424043 & 723910 & $\begin{array}{l}\text { Green River } 0.4 \text { miles below Stafford } \\
\text { Brook near Colrain }\end{array}$ & -. & 47.8 & 99.3 & 1.80 & 1,290 & 397 & 1 & \\
\hline 01170141 & 423912 & 723732 & $\begin{array}{l}\text { Green River below Workman Brook } \\
\text { near Greenfield }\end{array}$ & -- & 51.9 & 110 & 2.11 & 1,240 & 298 & 1 & \\
\hline \multicolumn{12}{|c|}{ Quaboag River Basin (subbasin of Chicopee River Basin) } \\
\hline 01175660 & 421730 & 720004 & $\begin{array}{l}\text { Sevenmile River at State Route } 31 \text {, } \\
\text { near Spencer }\end{array}$ & -- & 6.07 & 11.5 & 0.53 & 904 & 686 & 1 & \\
\hline 01175670 & 421554 & 720019 & Sevenmile River near Spencer & $\begin{array}{l}1961- \\
\text { present }\end{array}$ & 8.69 & 16.7 & 1.11 & 871 & 636 & 1 & \\
\hline 01175695 & 421326 & 720242 & $\begin{array}{l}\text { Sevenmile River at Podunk Street at } \\
\text { East Brookfield }\end{array}$ & -- & 40.6 & 80.8 & 4.55 & 891 & 607 & 1 & \\
\hline 01175905 & 421245 & 721214 & Quaboag River near Warren & -- & 138 & 298 & 29.9 & 815 & 594 & 1 & $\begin{array}{l}\text { Flood-retarding reservoirs } \\
\text { upstream. }\end{array}$ \\
\hline 01176000 & 421056 & 721551 & Quaboag River at West Brimfield & $\begin{array}{l}\text { 1913- } \\
\text { present }\end{array}$ & 149 & 319 & 31.7 & 809 & 397 & 1 & $\begin{array}{l}\text { Flood-retarding reservoirs } \\
\text { upstream. }\end{array}$ \\
\hline 01176350 & 420837 & 721850 & Quaboag River near Palmer & -- & 180 & 374 & 41.4 & 796 & 393 & 1 & $\begin{array}{l}\text { Flood-retarding reservoirs } \\
\text { upstream. }\end{array}$ \\
\hline 01176435 & 421043 & 722153 & Quaboag River at Three Rivers & -- & 212 & 415 & 50.5 & 777 & 341 & 1 & $\begin{array}{l}\text { Flood-retarding reservoirs } \\
\text { upstream. }\end{array}$ \\
\hline
\end{tabular}


Table 1. Descriptions of low-flow partial-record and streamgaging stations used to analyze the applicability of the drainage-area ratio method for estimating streamflow statistics for ungaged Massachusetts streams-Continued

\begin{tabular}{|c|c|c|c|c|c|c|c|c|c|c|c|}
\hline $\begin{array}{c}\text { USGS } \\
\text { station } \\
\text { No. }\end{array}$ & $\begin{array}{l}\text { Latitude } \\
\text { o." }\end{array}$ & Longitude & Station name & $\begin{array}{l}\text { Period of } \\
\text { record }\end{array}$ & $\begin{array}{l}\text { Drain- } \\
\text { age } \\
\text { area }\end{array}$ & $\begin{array}{l}\text { Total } \\
\text { stream } \\
\text { length }\end{array}$ & $\begin{array}{l}\text { Strati- } \\
\text { fied } \\
\text { drift } \\
\text { area }\end{array}$ & $\begin{array}{c}\text { Mean } \\
\text { basin } \\
\text { eleva- } \\
\text { tion }\end{array}$ & $\begin{array}{l}\text { Mini- } \\
\text { mum } \\
\text { basin } \\
\text { eleva- } \\
\text { tion }\end{array}$ & Region & Remarks \\
\hline \multicolumn{12}{|c|}{ West Branch Westfield River Basin (subbasin of Westfield River Basin) } \\
\hline 01180660 & 422000 & 730502 & $\begin{array}{l}\text { West Branch Westfield River at } \\
\text { Becket }\end{array}$ & - & 12.8 & 21.9 & 0.27 & 1,670 & 1,230 & 1 & \\
\hline 01180750 & 421647 & 725852 & $\begin{array}{l}\text { West Branch Westfield River at } \\
\text { Chester }\end{array}$ & $\cdots$ & 53.8 & 83.0 & 1.19 & 1,530 & 597 & 1 & \\
\hline 01180780 & 421626 & 730409 & Hamilton Brook at Becket Center & - & 1.15 & 1.47 & .0 & 1,730 & 1,570 & 1 & \\
\hline 01180800 & 421549 & 730248 & Walker Brook near Becket Center & $1963-76$ & 2.95 & 6.99 & .12 & 1,560 & 1,300 & 1 & \\
\hline 01180821 & 421640 & 725849 & $\begin{array}{l}\text { Walker Brook at State Route } 20 \text { at } \\
\text { Chester }\end{array}$ & -- & 72.5 & 117 & 2.58 & 1,510 & 596 & 1 & \\
\hline 01181000 & 421414 & 725346 & $\begin{array}{l}\text { West Branch Westfield River at } \\
\text { Huntington }\end{array}$ & $\begin{array}{l}\text { 1936- } \\
\text { present }\end{array}$ & 94.0 & 161 & 3.91 & 1,420 & 397 & 1 & \\
\hline
\end{tabular}


Absolute percent differences between the drainage-area ratio estimates and regression estimates, and the data-based estimates (correlation estimates for LFPR stations and calculated statistics for gaging stations) were determined for each of the streamflow statistics for each station. These absolute percent differences for the four statistics were averaged for each station to obtain the average percent difference for the estimation method at the station (table 7). The average absolute percent differences from the databased estimates for the drainage-area ratio method and the regression equations are plotted against the , drainage-area ratio for the station (the drainage area for the LFPR station divided by the drainage area for the index gaging station) in figure 5. Smoothed curves are plotted through each set of data to indicate the range of ratios in which the drainage-area ratio method provides generally better results than the regression equations. The smoothed curves were obtained by use of a LOWESS (LOcally-WEighted Scatter plot Smoother) algorithm (Minitab, Inc., 1998b, pp. 15-20 to 15-25, Cleveland, 1979).
The LOWESS curves indicate that differences between the data-based estimates and the drainage-area ratio method estimates are generally smaller than the differences between data-based estimates and the regression equation estimates when the ratio of the drainage area for the LFPR station is within about 0.3 and 1.5 times the drainage area of the index gaging station. This range of drainage area ratios was used to separate the data into four groups based on estimation method and whether the drainage-area ratio for the location was within the noted range. The groups were (1) drainage-area ratio estimates for stations with drainage-area ratios less than 0.3 and greater than 1.5 , (2) drainage-area ratio estimates for stations with drainage-area ratios between 0.3 and $1.5,(3)$ regression estimates for stations with drainage-area ratios less than 0.3 and greater than 1.5 , and (4) regression estimates for stations with drainage-area ratios between 0.3 and 1.5. Medians and standard deviations of the absolute percent differences are presented for each group in table 2 , along with the medians and standard deviations for all of the estimates, for all drainage-area ratio estimates, and for all regression-equation estimates.

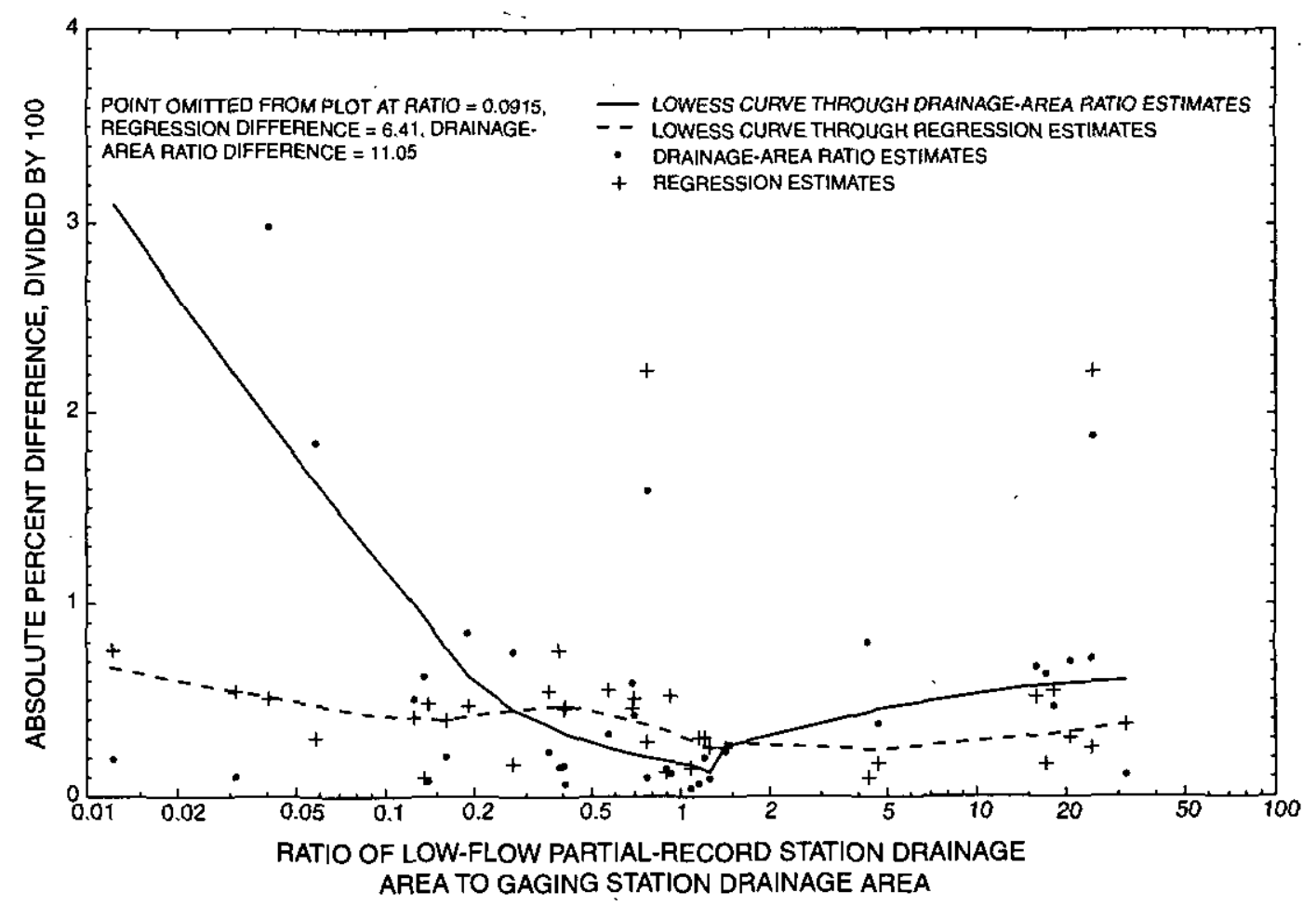

Figure 5. Relation of drainage-area ratio to average absolute percent difference in streamflow statistics between data-based estimates and estimates derived from the drainage-area ratio method (solid curve), and from the regression equations (dashed curve). 
Table 2. Medians and standard deviations of absolute percent differences between streamflow statistics estimated using available data and by using the drainage-area ratio method and regression equations

$[<$, actual value is less than value shown; $>$, actual value is greater than value shown]

\begin{tabular}{ccccc}
\hline Group & $\begin{array}{c}\text { Drainage- } \\
\text { area } \\
\text { ratio range }\end{array}$ & $\begin{array}{c}\text { Number } \\
\text { in group }\end{array}$ & $\begin{array}{c}\text { Median } \\
\text { absolute } \\
\text { percent } \\
\text { difference }\end{array}$ & $\begin{array}{c}\text { Standard } \\
\text { deviation }\end{array}$ \\
\hline All estimates & All & 72 & 40.3 & 151.6 \\
$\begin{array}{c}\text { Drainage- } \\
\text { area ratio }\end{array}$ & All & 36 & 34.9 & 186.0 \\
method & 0.3 and $>1.5$ & 20 & 65.7 & 240.8 \\
Regression & 0.3 to 1.5 & 16 & 15.5 & 37.7 \\
equations & All & 36 & 43.2 & 108.9 \\
& 0.3 and $>1.5$ & 20 & 40.3 & 140.4 \\
& 0.3 to 1.5 & 16 & 45.5 & 48.6 \\
\hline
\end{tabular}

Table 2 shows that the median absolute percent difference for the drainage-area ratio method is about 8 percent lower than that for the regression equations when all the data are considered; however, the standard deviation for the drainage-area ratio method is much larger than that for the regression equations. When drainage-area ratios for the stations are between 0.3 and 1.5 , the median difference for the drainage-area ratio method is about 30 percent less and the standard deviation is about 11 percent less than the corresponding values for the regression equations. When drainage-area ratios for the stations are less than 0.3 or greater than 1.5 , the median difference for the drainage-area ratio method is about 25 percent greater and the standard deviation is about 100 percent greater than the corresponding values for the regression equations.

Statistical tests were done on the grouped data to test for significant differences in the variances and medians of the groups. Differences in variance were tested by use of Levene's test for homogeneity of variances (Minitab, Inc., 1998b, p. 3-48 to 3-51). Levene's test was used because the data were not normally distributed, and this test is applicable for any continuous distribution. Although there are substantial differences in variance among the groups, none of the groups could be considered significantly different from the others based on the test. Differences in medians were tested by use of the Mann-Whitney rank-sum test (Minitab, Inc., 1998b, p. 5-11 to 5-13). This test showed that the median difference for the drainagearea ratio estimates is significantly larger $(p=0.052)$ than the median difference for the regression equation estimates when the drainage-area ratio is less than 0.3 or greater than 1.5 . The test also showed that the median difference of the drainage-area ratio estimates is significantly less than $(p=0.003)$ the median difference of the regression equation estimates when the drainage-area ratio is between 0.3 and 1.5.

On the basis of the above analysis, it should be expected that the drainage-area ratio method will provide estimates of streamflow statistics that are, on average, as good as or better than estimates obtained using the regression equations tested when the drainage-area ratio is between about 0.3 and 1.5. It should be noted, however, that this finding is based on a comparison of differences between two types of estimates (drainage-area ratio estimates and regression equation estimates) and a third type of estimate (correlation estimates) for the LFPR stations used in the analysis. It was not possible to test the estimation methods against only observed statistics for streamgaging stations, as would be preferred, because there were too few streamgaging stations available for the analysis that were located on the same, unregulated streams. The finding was also based on a comparison of drainage-area ratio estimates with estimates from regression equations that are now superseded by the equations provided later in this report. Results would likely differ somewhat if the new equations were used; however, time and funding were not available to update the analysis.

The upper limit of the drainage-area ratio range in which the drainage-area ratio estimation method is recommended for use over use of regression equations is poorly defined because there are only two data points (at 4.33 and 4.67) between ratios of 1.42 and 15.9. Absolute percent differences were larger for the drainage-area ratio estimates than for the regression estimates at the drainage-area ratios of 4.33 and 4.67 , but the upper limit of the recommended range of drainage-area ratios could be anywhere between 1.42 and 4.33. In addition, users of the drainage-area ratio method also should consider that potential errors of estimates for individual sites cannot be quantified. If a standard error of estimate or confidence intervals are needed, then it may be useful to use the regression equations to obtain the estimates. 


\section{Regression Equations}

Multiple linear-regression analysis (regression analysis) has been used by the USGS and other researchers throughout the United States and elsewhere to develop equations for estimating streamflow statistics for ungaged sites. In regression analysis, a streamflow statistic (the dependent variable) for a group of data-collection stations is statistically related to one or more physical or climatic characteristics of the drainage areas for the stations (the independent variables). This results in an equation that can be used to estimate the statistic for sites where no streamflow data are available. Equations can be developed by use of several different regression analysis algorithms. The various algorithms use different methods for minimizing differences between the values of the dependent variable for the stations used in the analysis (the observed values) and the corresponding values provided by the resulting regression equation (the estimated or fitted values). Choice of one algorithm over another depends on the characteristics of the data used in the analysis and on the underlying assumptions for use of the algorithm.

Equations obtained by use of regression analysis take the general form

$$
Y_{i}=b_{0}+b_{1} X_{1}+b_{2} X_{2}+\ldots+b_{n} X_{n}+\varepsilon_{i}
$$

where $Y_{i}$ is the estimate of the dependent variable for site $i, X_{1}$ to $X_{n}$ are the $n$ independent variables, $b_{0}$ to $b_{n}$ are the $n+1$ regression model coefficients, and $\varepsilon_{i}$ is the residual error (difference between the observed and estimated value of the dependent variable) for site $i$. Assumptions for use of regression analysis are (1) equation 12 adequately describes the relation between the dependent and the independent variables, (2) the mean of the $\varepsilon_{i}$ is zero, (3) the variance of the $\varepsilon_{i}$ is constant and independent of the values of $X_{n},(4)$ the $\varepsilon_{i}$ are normally distributed, and (5) the $\varepsilon_{i}$ are independent of each other (Iman and Conover, 1983, p. 367). Regression analysis results must be evaluated to assure that these assumptions are met.

Streamflow and basin characteristics used in hydrologic regression usually are log-normally distributed; therefore, transformation of the variables to logarithms is usually necessary to satisfy regression assumption 2. Transformation results in a model of the form

$$
\begin{aligned}
\log Y_{i}= & b_{0}+b_{1} \log X_{1}+b_{2} \log X_{2}+\ldots \\
& +b_{n} \log X_{n}+\varepsilon_{i} .
\end{aligned}
$$

The algebraically equivalent form when logarithmsbase 10 are used in the transformations and the equation is retransformed to original units is:

$$
Y_{i}=10^{b_{0}}\left(X_{1}^{b_{1}}\right)\left(X_{2}^{b_{2}}\right) \ldots\left(X_{n}^{b_{n}}\right) 10^{\varepsilon_{i}}
$$

The Generalized-Least-Squares (GLS) regression algorithm (Tasker, 1989) was developed for use in regression analysis of peak-and low-flow frequency statistics, such as the 100-year peak flow and the 7-day, 10-year low flow, because streamflow data are correlated spatially and in time. Thus, assumption 5 for use of regression is not strictly satisfied in hydrologic regressions when the most commonly used form of regression analysis, OrdinaryLeast-Squares (OLS), is used. Tasker and Stedinger (1989) demonstrated that GLS analysis is theoretically most appropriate and generally provides the best results when used for hydrologic regressions. GLS allows the weight given to each station used in the analysis to be adjusted to compensate for spatial correlation and differences in record length among the stations. Because GLS was developed specifically for use with flow-frequency statistics, however, it requires substantial extra effort to use it for regression with flow-duration statistics (Ries, 1994b)

Vogel and Kroll (1990) used GLS to develop a regression equation to predict 7-day, 10-year low flows for Massachusetts streams; however, they found that the equation parameters $\left(b_{0}\right.$ to $b_{\mathrm{n}}$ ) were nearly identical when either OLS or GLS was used to develop the equation even though OLS does not correct for differences in record length or cross-correlation among the stations used in the analysis. In addition, Vogel and Kroll (1990) found that prediction errors obtained when GLS was used were only marginally smaller than those obtained when OLS was used.

Weighted-Least-Squares regression analysis (WLS) was used to develop the equations presented in this report for estimating the 99-, 98-, 95-, 90-, 85-, 80-, 75-, 70-, 60-, and 50-percent duration flows; the 7-day, 10- and 2- year low flows; and the August median flow. WLS can compensate for differences in record length, but it does not correct for crosscorrelation among the stations used in the analysis. Stedinger and Tasker (1985) concluded that gains in 
model precision when GLS is used instead of WLS increase with decreasing standard error of estimate and increasing cross correlation. WLS and GLS models with large standard errors and low cross correlations were nearly identical. Because Vogel and Kroll (1990) found cross correlation of data they used in their analysis was only 0.35 , equations for predicting lowflow statistics for Massachusetts streams using WLS should have model precision that is nearly the same as equations developed using GLS. Additionally, the WLS algorithm can easily be used to adjust the weights for stations used in the analysis to compensate for nonconstant variance of the regression residuals when this is necessary to avoid a violation of regression assumption 3.

When several independent variables are being considered for use in a regression analysis, usually a variable-selection algorithm is necessary to aid in determining which combination of the independent variables provides the best estimates of the dependent variable. Neter and others (1985, p. 421-429) describe an all-possible-regressions algorithm that examines all possible combinations of the independent variables and ranks them according to some criterion. This algorithm was used for the Basin Yield studies to select subsets of the independent variables for inclusion in the final regression equations, with minimization of Mallow's $C_{p}$ used as the selection criterion (Neter and others, 1985 , p. 426-428). These subsets were further analyzed using WLS regression analysis to select a final model for each analyzed streamflow statistic. The final models were selected on the basis of the following statistical parameters: (1) Mallow's $C_{p}$ statistic; (2) $R_{a d j}^{2}$, the percentage of the variation in the dependent variable explained by the independent variables, adjusted for the number of stations and the number of independent variables used in the regression analysis; (3) the mean square error (MSE), the sample model error variance of the estimates for the stations included in the analysis; and (4) the PRESS statistic, an estimate of the prediction error sum of squares (Montgomery and Peck, 1982, p. 255). Diagnostic checks were done to test for model adequacy and violations of assumptions for regression analysis. The independent variables selected for the final models had to be statistically significant at the 95-percent confidence level, and the signs and magnitudes of the coefficients had to be hydrologically reasonable.
Equation 13 provides unbiased estimates of the mean response of the dependent variable, meaning that the expected value of $\varepsilon_{i}$ is zero. However, equation 13 yields estimates of the logarithm-base 10 of the dependent variable when what is desired is estimates in their original units of measure. Equation 14 is a retransformation of equation 13 that produces estimates in the desired units, but it predicts the median rather than the mean response of the dependent variable, and thus it is biased. In the case of streamflow data, the median tends to be lower than the mean.

Several investigators have discussed the problems of bias in retransformed logarithmic equations and proposed various bias-correction factors (BCF) as solutions (Bradu and Mundlak, 1970; Duan, 1983; Ferguson, 1986; Koch and Smillie, 1986; Cohn and others, 1989; Gilroy and others, 1990). Duan's "smearing estimate" was used as the BCF in previous Basin Yield studies (Ries, 1994a, 1994b, 1997) by replacing the error term of equation 14 with the mean error of the retransformed residuals. This BCF is advantageous in that it does not require normally distributed regression residuals and is simple to calculate.

Cohn and others (1989) show that if the residuals are normally distributed a BCF developed by Bradu and Mundlak (1970) is optimal, in that it provides Minimum Variance Unbiased Estimates (MVUE) of the dependent variable. Gilroy and others (1990) demonstrate that the MVUE estimator and Duan's smearing estimator are about equally effective at eliminating retransformation bias, however the MVUE estimator has the advantage of being unbiased regardless of the number of stations used in the analysis. Equations for computing the MVUE estimator are provided in Cohn and others (1989) and in Gilroy and others (1990). Because of their complexity, they are not reproduced here. Cohn and others (1989) also provided a FORTRAN program for computing the MVUE BCF. This program was used to determine MVUE factors for the regression equations provided later in this report. Smearing estimate BCFs were also determined for the regression equations. Estimated streamflow statistics for the stations used in the regression analyses were determined from equations using both types of BCFs, and the means of the estimates were compared against the means of the observed data. The means of the MVUE estimates were 
generally closer to the means of the observed data than the means of the smearing estimates, thus the MVUE estimates were used in the final equations.

\section{Data Base Development}

Streamflow statistics and basin characteristics were included in the regression analyses for 37 gaging stations and 107 LFPR stations. Streamflows at all of the stations included in the analyses were essentially unregulated during low streamflow periods. Thirty-four streamgaging stations were in Massachusetts and three were in bordering states (two in Rhode Island and one in Connecticut) but had more than two-thirds of their drainage areas in Massachusetts. Available records through climatic year 1995 were used to compute the streamflow statistics for the gaging stations. Record lengths range from 2 to 83 years, with a median of 27 years (table 3 ). Streamflow statistics were also computed for 14 other streamgaging stations that were not used in the analyses but were used to estimate streamflow statistics for the LFPRs. Names and descriptions of the streamgaging stations are in table 3. Locations of the streamgaging stations and the LFPR stations are shown in figure 1.

All 107 LFPR stations used in the analyses were in Massachusetts. Names and descriptions of the LFPR stations are in table 8 (at back of report). The LFPRs had from 8 to 36 streamflow measurements available for relation to streamgaging-station discharge records, with a median of 14 measurements. One-quarter of the LFPR stations had 10 or fewer measurements, and onequarter had 18 or more measurements. Calculated streamflow statistics in cubic feet per second for the streamgaging stations and estimated streamflow statistics for the LFPR stations used in the analyses, along with variances in base-10 logarithms, standard errors in percent, and years of record for streamgaging stations or equivalent years of record for LFPR stations are provided in table 9 (at back of report). These statistics were calculated or estimated using the methods described earlier in this report.

Basin characteristics measured for use in the analyses were selected on the basis of their theoretical relation to differences in flow magnitudes of streams, results of previous studies in similar hydrologic environments, and on the ability to measure them. The characteristics measured were drainage area, in square miles; areas of stratified drift, wetlands, and water bodies, in square miles; total length of streams, in miles; maximum, minimum, and mean basin elevation, in feet; maximum, minimum, and mean elevation in stratified drift, in feet; and mean basin slope, in percent. The measured basin characteristics for the stations used in the regression analyses are provided in table 10 (at back of the report).

All basin characteristics were measured from digital-map data using an automated GIS procedure developed for the Basin Yield studies. The automated procedure was created using the AML programming language of the ARC/INFO GIS software (Environmental Systems Research Institute, Inc., 1990). The automated procedure determines the drainage-basin boundary for any selected site on a Massachusetts stream and creates a digital data layer of the basin boundary. The procedure determines the drainage-basin boundary for the site, then overlays the boundary on the other digital data layers to determine the other basin characteristics for the site. The digital data layers used by the procedure include (1) drainage subbasins at $1: 24,000$ scale, (2) hydrography at $1: 25,000$ scale, (3) surficial geology at 1:125,000 scale, and (4) Digital Elevation Models (DEMs) at 1:25,000 scale and 1:250,000 scale. These data layers are documented by and are available from MassGIS (http://www.state.ma.us/mgis) as separate products. They have also been packaged into a watershed library (http://www.state.ma.us/mgis/ix_wat.htm), which also contains several derivative data layers needed for using the automated procedure.

The drainage subbasins data layer includes drainage-basin boundaries for about 2300 locations in Massachusetts and areas in other states that contribute streamflow to Massachusetts. Subbasin boundaries for most USGS data-collection stations are included in the data layer. The subbasin boundaries were delineated by the USGS and digitized by MassGIS, and average about $4 \mathrm{mi}^{2}$ in extent.

The hydrography data comprise three layers, one each for streams, water bodies, and wetlands. These data were scanned from Mylar separates of the three types of blue-line features from 1:25,000-scale USGS topographic quadrangle maps. The streams were enhanced by adding centerlines through the water bodies, wetlands, and streams represented on the maps by double lines. This enhancement allows accurate measurements of total stream length to be obtained, and also creates a stream network that enables flow routing. 
Table 3. Descriptions of streamgaging stations used in the regression analysis and for correlation with low-flow partial record stations, or both

[Period of record: Periods of record shown are based on climatic years, which begin on April 1 of the year noted. The word "present" refers to the year of publication for this report (2000). No., number]

\begin{tabular}{|c|c|c|c|c|c|}
\hline $\begin{array}{l}\text { Station } \\
\text { No. }\end{array}$ & \begin{tabular}{l} 
Latitude \\
\hdashline,$"$
\end{tabular} & $\underset{0}{\text { Longitude }}$ & Station name & $\begin{array}{l}\text { Period of } \\
\text { record }\end{array}$ & Remarks \\
\hline \multicolumn{6}{|c|}{ Streamgaging stations used in the regression analysis and for correlation with low-flow partial-record stations } \\
\hline 01096000 & 423803 & 713930 & $\begin{array}{l}\text { Squannacook River near West Groton, } \\
\text { Mass. }\end{array}$ & 1950-present & Occasional regulation by mill upstream \\
\hline 01096910 & 422704 & 711343 & Boulder Brook at East Bolton, Mass. & $1972-82$ & - \\
\hline 01097300 & 423039 & 712425 & Nashoba Brook near Acton, Mass. & 1964-present & -- \\
\hline 01100700 & 424841 & 710159 & $\begin{array}{l}\text { East Meadow Brook near Haverhill, } \\
\text { Mass. }\end{array}$ & $1963-73$ & -- \\
\hline 01101000 & 424510 & 705646 & Parker River at Byfield, Mass. & 1946-present & Occasional regulation by mill and ponds \\
\hline 01105600 & 421125 & 705643 & $\begin{array}{l}\text { Old Swamp River near South } \\
\text { Weymouth, Mass. }\end{array}$ & 1966-present & -- \\
\hline 01106000 & 413330 & 710747 & Adamsville Brook at Adamsville, R.I. & $1941-77$ & -- \\
\hline 01107000 & 420341 & 710359 & Dorchester Brook near Brockton, Mass. & $1963-73$ & - \\
\hline 01109200 & 415246 & 711518 & $\begin{array}{l}\text { West Branch Palmer River near } \\
\text { Rehoboth, Mass. }\end{array}$ & $1962-73$ & $\cdots$ \\
\hline 01111200 & 420617 & 713628 & $\begin{array}{l}\text { West River at West Hill Dam near } \\
\text { Uxbridge, Mass. }\end{array}$ & $1962-89$ & Flood-control dam upstream \\
\hline 01111300 & 415852 & 714111 & Nipmuc River near Harrisville, R.I. & $\begin{array}{l}\text { 1964-90, } \\
\text { 1994-present }\end{array}$ & -- \\
\hline 01162500 & 424057 & 720656 & Priest Brook near Winchendon, Mass. & 1919-present & No daily record during August 1936 \\
\hline 01165500 & 423610 & 722136 & Moss Brook at Wendell Depot, Mass. & $1917-81$ & \\
\hline 01166105 & 423539 & 722141 & $\begin{array}{l}\text { Whetstone Brook at Wendell Depot, } \\
\text { Mass. }\end{array}$ & $1986-90$ & - \\
\hline 01169000 & 423818 & 724332 & North River at Shattuckville, Mass. & 1940 -present & Occasional small diurnal fiuctuation \\
\hline 01169900 & 423231 & 724139 & South River near Conway, Mass. & 1967-present & Small diurnal fiuctuation since 1982 \\
\hline 01170100 & 424212 & 724016 & Green River near Colrain, Mass. & 1968-present & -- \\
\hline 01171500 & 421905 & 723921 & Mill River at Northampton, Mass. & 1939-present & - \\
\hline 01171800 & 421809 & 724116 & Bassett Brook near Northampton, Mass. & $1963-73$ & -- \\
\hline 01173260 & 422352 & 720851 & Moose Brook near Barre, Mass. & $1963-73$ & -- \\
\hline 01174000 & 422842 & 722005 & Hop Brook near New Salem, Mass. & $1948-81$ &.- \\
\hline 01174050 & 422849 & 721327 & $\begin{array}{l}\text { East Branch Fever River near Petersham, } \\
\text { Mass. }\end{array}$ & $1984-85$ & -- \\
\hline 01174565 & 422718 & 722256 & $\begin{array}{l}\text { West Branch Swift River at Shutesbury, } \\
\text { Mass. }\end{array}$ & $1984-85$ & -- \\
\hline 01174900 & 422008 & 722212 & Cadwell Creek near Belchertown, Mass. & 1962-present & -- \\
\hline 01175670 & 421554 & 720019 & Sevenmile River near Spencer, Mass. & 1961-present & $\begin{array}{l}\text { Occasional regulation by ponds } \\
\text { upstream }\end{array}$ \\
\hline 01176000 & 421056 & 721551 & Quaboag River at West Brimfield, Mass. & 1913-present & Flood-retarding reservoirs upstream \\
\hline 01180000 & 421727 & 725215 & Sykes Brook at Knightville, Mass. & $1946-72$ & -- \\
\hline 01180500 & 421531 & 725223 & $\begin{array}{l}\text { Middle Branch Westfield River at Goss } \\
\text { Heights, Mass. }\end{array}$ & $1910-89$ & $\begin{array}{l}\text { Data for August 1965-66 not used due } \\
\text { to construction of flood-control } \\
\text { reservoir upstream }\end{array}$ \\
\hline
\end{tabular}


Table 3. Descriptions of streamgaging stations used in the regression analysis and for correlation with low-flow partial record stations, or both-Continued

\begin{tabular}{|c|c|c|c|c|c|}
\hline $\begin{array}{l}\text { Station } \\
\text { No. }\end{array}$ & $\begin{array}{l}\text { Latitude } \\
\text { o'" }\end{array}$ & $\begin{array}{l}\text { Longitude } \\
\text { o," }\end{array}$ & Station name & $\begin{array}{l}\text { Period of } \\
\text { record }\end{array}$ & Remarks \\
\hline \multicolumn{6}{|c|}{ Streamgaging stations used in the regression analysis and for correlation with low-flow partial-record stations-Continued } \\
\hline 01180800 & 421549 & 730248 & Walker Brook near Becket Center, Mass. & $1963-76$ & -- \\
\hline 01181000 & 421414 & 725346 & $\begin{array}{l}\text { West Branch Westfield River at } \\
\text { Huntington, Mass. }\end{array}$ & 1936-present & -- \\
\hline 01187400 & 420203 & 725549 & Valley Brook near West Hartland, Conn. & $1941-71$ & -. \\
\hline 01197015 & 423112 & 731348 & $\begin{array}{l}\text { Town Brook at Bridge Street, } \\
\text { Lanesborough, Mass. }\end{array}$ & $1981-82$ & -- \\
\hline 01197300 & 422059 & 731756 & Marsh Brook at Lenox, Mass. & $1963-73$ & -. \\
\hline 01198000 & 421131 & 732328 & $\begin{array}{l}\text { Green River near Great Barrington, } \\
\text { Mass. }\end{array}$ & $\begin{array}{l}1952-70,1994 \\
1995\end{array}$ & $-\cdot$ \\
\hline 01331400 & 423520 & 730648 & Dry Brook near Adams, Mass. & $1963-73$ & -- \\
\hline 01332000 & 424208 & 730537 & $\begin{array}{l}\text { North Branch Hoosic River at North } \\
\text { Adams, Mass. }\end{array}$ & $1932-89$ & Infrequent small diurnal fluctuation \\
\hline 01333000 & 424232 & 731150 & Green River at Williamstown, Mass. & 1950-present & Infrequent small diurnal fluctuation \\
\hline \multicolumn{6}{|c|}{ Streamgaging stations used for correlation with low-flow partial-record stations, but not used in the regression analysis } \\
\hline 01073000 & 430855 & 705756 & Oyster River near Durham, N.H. & 1935-present & -- \\
\hline 01105730 & 420602 & 704923 & Indian Head River at Hanover, Mass. & 1967-present & Some regulation by mills and ponds \\
\hline 01105870 & 415927 & 704403 & Jones River at Kingston, Mass. & 1967-present & $\begin{array}{l}\text { Regulation by pond and cranberty bogs. } \\
\text { Ground- and surface-water drainage } \\
\text { boundaries do not coincide }\end{array}$ \\
\hline 011058837 & 413532 & 703030 & $\begin{array}{l}\text { Quashnet River at Waquoit Village, } \\
\text { Mass. }\end{array}$ & 1989-present & $\begin{array}{l}\text { Some regulation by cranberry bog. } \\
\text { Ground- and surface-water drainage } \\
\text { boundaries do not coincide }\end{array}$ \\
\hline 01109000 & 415651 & 711038 & Wading River near Norton, Mass. & 1926-present & $\begin{array}{l}\text { Regulation by lakes and ponds. } \\
\text { Diversions to and from basin for } \\
\text { municipal supplies }\end{array}$ \\
\hline 01109403 & 414951 & 712106 & Ten Mile River at East Providence, R.I. & 1987-present & $\begin{array}{l}\text { Regulations and diversions from } \\
\text { reservior }\end{array}$ \\
\hline 01118000 & 412953 & 714301 & Wood River at Hope Valley, R.I. & 1942-present & $\begin{array}{l}\text { Seasonal regulation by pond since } 1968 . \\
\text { Regulation at low flow until } 1952\end{array}$ \\
\hline 01121000 & 415037 & 721010 & $\begin{array}{l}\text { Mount Hope River near Warrenville, } \\
\text { Conn. }\end{array}$ & 1941-present & Occasional regulation by ponds \\
\hline 01184490 & 415450 & 723300 & Broad Brook at Broad Brook, Conn. & 1962-present & Regulation by reservoir and mill \\
\hline 01187300 & 420214 & 725622 & $\begin{array}{l}\text { Hubbard River near West Hartland, } \\
\text { Conn. }\end{array}$ & $\begin{array}{l}\text { 1939-55, } \\
\text { 1957-present }\end{array}$ & - \\
\hline 01188000 & 414710 & 725755 & $\begin{array}{l}\text { Burlington Brook near Burlington, } \\
\text { Conn. }\end{array}$ & 1932-present & -- \\
\hline 01197000 & 422810 & 731149 & $\begin{array}{l}\text { East Branch Housatonic River at } \\
\text { Coltsville, Mass. }\end{array}$ & 1936-present & $\begin{array}{l}\text { Flow regulated by powerplants and } \\
\text { reservoir. Diversion for municipal } \\
\text { supply }\end{array}$ \\
\hline 01198500 & 420126 & 732032 & Blackberry Brook at Canaan, Conn. & $1950-71$ & -- \\
\hline 01199050 & 415632 & 732329 & Salmon Creek at Lime Rock, Conn. & 1962-present & -- \\
\hline
\end{tabular}


The surficial geology data layer includes seven categories: (1) sand and gravel deposits, (2) till or bedrock outcrops, (3) sandy till over sand, (4) end moraines, (5) large sand deposits, where distinguished from șand and gravel deposits, (6) fine-grained deposits, and (7) floodplain alluvium. The automated procedure determines the total area in each category. within the drainage-basin area. Each category was tested separately as a basin characteristic and in combination with other categories in preliminary regression analyses.

The 1:25,000-scale DEM data were used to define or aid in defining drainage-basin boundaries for locations on streams where basin characteristics and streamflow statistics were needed. The DEM data used for the boundary delineations were processed so that the stream network derived from the DEMs would conform exactly with the data layer of streams derived from the USGS topographic maps. This was necessary to assure correct automatic delineation of drainage boundaries. When a user of the automated procedure selects a location on a stream for which no boundary exists in the subbasin boundary data layer, the modified DEMs are used to determine the boundary for the location up to the points at which the new boundary intersects existing boundaries in the subbasin boundary data layer. The previously defined boundaries are then used to define the remainder of the boundary and the drainage area for the new location. This process minimizes reliance on the DEMs for determining drainage boundaries for selected locations, however drainage boundaries for some small basins are determined entirely from the modified DEMs. The original (un-processed) 1:25,000-scale DEMs were used to determine minimum, mean, and maximum elevations in the drainage basin and also in the stratified-drift areas in the basin. The 1:250,000-scale DEMs were used to compute mean basin slopes, in percent.

Some of the measured basin characteristics were combined to determine additional characteristics for use in the analyses. These characteristics included (1) relief, in feet, computed by subtracting the minimum from the maximum basin elevation; (2) relief in stratified-drift areas, in feet, computed by subtracting the minimum from the maximum elevation in the stratified-drift areas within the basin; (3) GWHEAD, in feet, a surrogate used in previous Basin Yield studies for the effective head in the stratified drift, computed by subtracting the minimum from the mean basin elevation; (4) drainage density, in miles per square mile, computed by dividing the total stream length by the basin area; (5) percentage of water bodies, computed by dividing the area of water bodies by the basin area, and multiplying the result by $100 ;(6)$ percentage of wetlands, computed by dividing the area of wetlands by the basin area, and multiplying the result by 100 ; (7) percentage of storage, computed by adding the areas of wetlands and water bodies, dividing by the basin area, and multiplying the result by $100 ;(8)$ total percentage of stratified drift, computed by dividing the total area of surficial geology categories $1,5,6$, and 7 by the basin area, and multiplying the result by 100 ; (9) total drift per unit stream length, in square miles per mile, computed by dividing the total area of surficial geology categories $1,5,6$, and 7 by the total stream length; (10) percent coarse-grained drift, computed by dividing the area of surficial geology categories 1,5 , and 7 by the basin area, and multiplying the result by 100; and (11) coarse-grained drift per unit stream length, in square miles per mile, computed by dividing the area of surficial geology categories 1,5 , and 7 by the total stream length.

Several of the stations that were used in the regression analyses were also used in the drainagearea-ratio analysis described previously. In some cases, the streamflow statistics shown for these stations in table 7 differ from those shown in table 10, and the basin characteristics shown in table 9 differ from those shown in table 1 . The streamflow statistics differ because the regression analyses were done two years after the drainage-area-ratio analysis was done, and during that time period the methods for determining streamflow statistics for the LFPR sites was improved, and in some cases additional streamflow measurements were made at the sites. The basin characteristics differ because the data layers, GIS methods, and regression equations used for the drainage-area ratio analysis were those described by Ries (1994b, 1997), and they differ from the data layers, GIS methods, and equations described in this report. Values shown in tables 9 and 10 supersede those shown in tables 1 and 7.

\section{Development of the Equations}

Regression equations for predicting the 99-, 98-, 95-, 90-, 85-, 80-, 75-, 70-, 60-, and 50-percent duration flows; the 7-day, 10- and 2- year low flows; and the August median flow were developed using WLS regression, as described above. The equations are presented in table 4, along with the number of stations used in the analysis and several measures of model adequacy. 
Table 4. Summary of regression equations developed for estimating low-flow statistics for Massachusetts streams

[Statistic: $P_{x x}$ is the xx-percent duration flow, $Q_{7, y}$ is the 7-day, $y$-year low flow, Augso is the August median flow, all in cubic feet per second. Equation: $D A$ is drainage area (square miles); $S L$ is mean basin slope (percent); $D R / S T$ is area of stratified drift per unit of total stream length (square miles per mile); $R E G$ is region, 0 for eastern, I for western, $\boldsymbol{R}_{a d j}^{2}$ : Coefficient of determination (percent). $S E_{r}$ and $S E p$ : Average standard errors of estimate and prediction, respectively (percent). MAD: Median absolute deviation (percent)]

\begin{tabular}{|c|c|c|c|c|c|c|}
\hline Statistic & Equation & $\begin{array}{c}\text { Number } \\
\text { of } \\
\text { stations }\end{array}$ & $\boldsymbol{R}_{a d j}^{2}$ & $S E_{r}$ & $S E_{p}$ & MAD \\
\hline$P_{50}^{\prime}$ & $0.955(D A)^{1.020}$ & 87 & 98.1 & 17.3 & 17.6 & 13.4 \\
\hline$P_{60}$ & $0.763(D A)^{1.050}(D R / S T+0.1)^{0.123}$ & 97 & 97.6 & 19.2 & 19.8 & 15.5 \\
\hline$P_{70}$ & $0.607(D A)^{1.070}(D R / S T+0.1)^{0.357} 10^{0.121(R E G)}$ & 115 & 96.7 & 22.7 & 23.5 & 17.8 \\
\hline$P_{75}$ & $0.509(D A)^{1.080}(D R / S T+0.1)^{0.432} 10^{0.158(R E G)}$ & 123 & 95.9 & 25.0 & 25.8 & 20.6 \\
\hline$P_{80}$ & $0.507(D A)^{1.060}(S L)^{0.191}(D R / S T+0.1)^{0.693} 10^{0.145(R E G)}$ & 129 & 95.2 & 27.3 & 28.4 & 18.8 \\
\hline$P_{85}$ & $0.365(D A)^{1.080}(S L)^{0.255}(D R / S T+0.1)^{0.746} 10^{0.159(R E G)}$ & 133 & 95.0 & 30.8 & 31.9 & 21.0 \\
\hline $\mathrm{P}_{90}$ & $0.329(D A)^{1.080}(S L)^{0.396}(D R / S T+0.1)^{0.985} 10^{0.160(R E G)}$ & 132 & 94.0 & 35.2 & 36.6 & 26.8 \\
\hline $\mathrm{P}_{95}$ & $0.171(D A)^{1.120}(S L)^{0.457}(D R / S T+0.1)^{0.999} 10^{0.190(R E G)}$ & 126 & 92.1 & 43.7 & 45.6 & 31.0 \\
\hline $\mathrm{P}_{98}$ & $0.116(D A)^{1.130}(S L)^{0.412}(D R / S T+0.1)^{1.030} 10^{0.247(R E G)}$ & 124 & 87.8 & 57.9 & 60.3 & 35.1 \\
\hline$P_{99}$ & $0.082(D A)^{1.160}(S L)^{0.427}(D R / S T+0.1)^{1.050} 10^{0.255(R E G)}$ & 119 & 86.7 & 62.4 & 65.1 & 37.3 \\
\hline $\mathrm{Q}_{7,2}$ & $0.173(D A)^{1.130}(S L)^{0.272}(D R / S T+0.1)^{0.858} 10^{0.199(R E G)}$ & 119. & 88.5 & 47.3 & 49.5 & 28.0 \\
\hline$Q_{7,10}$ & $0.080(D A)^{1.170}(S L)^{0.514}(D R / S T+0.1)^{1.180} 10^{0.260(R E G)}$ & 114 & 84.4 & $67.7^{\circ}$ & 70.8 & 36.7 \\
\hline Aug $_{50}$ & $0.418(D A)^{1.080}(S L)^{0.175}(D R / S T+0.1)^{0.745} 10^{0.192(R E G)}$ & 131 & 95.1 & 31.5 & 33.2 & 23.1 \\
\hline
\end{tabular}

The measures of model adequacy include (1) the coefficient of determination, otherwise known as the adjusted R-squared $\left(R_{a d j}^{2}\right)$; (2) the average standard error of estimate, $S E_{r}$, in percent; (3) the average standard error of prediction, $S E_{p}$, in percent; and (4) the median absolute deviation (MAD), in percent. The $R_{a d j}^{2}$ is a measure of the proportion of the variation in the dependent variable that is explained by the independent variables, adjusted for the number of stations and the number of independent variables used in the analysis. The $S E_{r}$ is a measure of the average precision with which the regression equations estimate the streamflow statistics for stations used in the analyses, whereas the $S E_{p}$ indicates the average precision with which the equations can be used to estimate streamflow statistics for ungaged sites with basin characteristics similar to those for the stations used in the regression analyses. About 68 percent of streamflows estimated by using regression equations will have errors within the noted average standard errors. Half of the regression-equation estimates for stations used in the analyses had absolute errors, in percent, that were greater than the MAD, and half of them were less than the MAD.

The number of stations used in the analyses ranged from 87 (34 streamgaging stations and 53 LFPR stations) for the equation for the 50-percent duration to
133 (34 streamgaging stations and 99 LFPR stations) for the equations for the 85- percent duration. The number of stations differed because limits were placed on the standard errors of estimate allowed for the LFPR stations used in the analysis, and because some stations were removed from the analyses because they were outliers. Limits of standard errors of estimate set for inclusion of LFPR stations in the analyses were 30 percent for the 99-percent duration flow and the 7-day, 10-year low flow; 25 percent for the 98-percent duration flow; 20 percent for the 95-percent duration flow and the 7-day, 2-year low flow; and 15 percent for all other statistics. The limits were set higher for the lower flows because, for the same error in flow in cubic feet per second, the percentage error increases as the actual flow decreases. Streamflow statistics were omitted from table 9 for stations not used in the regression analyses.

\section{Weighting Procedure}

According to Montgomery and Peck (1982, p. 99), when observations of the dependent variable in a regression analysis have different accuracies, the individual observations should be assigned weights that are inversely proportional to their variances. Because of this, weights for the stations used in the regression 
analyses were initially assigned as the reciprocal of the variances of the streamflow statistics, shown for each statistic for each station in table 9. However, weighted residuals from initial regression analyses using these weights were not normally distributed, as stations with very large or small variances relative to the others tended to be outliers. Plots of the weighted residuals showed that the LFPR stations mostly formed a large, dense cluster, whereas the gaging stations were more scattered. This clustering of LFPR stations was more pronounced for the lower (in flow) flow-duration statistics than for the higher flow-duration statistics; this was caused by the fact that variances for the flowduration statistics for the LFPR stations were mostly substantially higher than those for the streamgaging stations. Variances for the streamgaging stations and the LFPR stations were similar for the 7-day, 2- and 10-year low-flow frequency statistics, but very high or low variances for individual stations still caused those stations to be outliers, thus causing non-normal residuals. Because of this, another weighting scheme was needed that was theoretically reasonable, would reduce the number of weight-induced outliers, and would not cause the weighted residuals for the LFPR and streamgaging stations to form separate clusters.

Record length often has been used in hydrologic regression analyses as an easily calculated surrogate to weight the stations according to differences in the accuracy of their streamflow statistics. Record length is used to adjust the weights for the stations in the GLS regression algorithm (Tasker, 1989). Record length can be used for the weights because the variance of a streamflow statistic at a streamgaging station is highly inversely related to the record length for the station. When LFPR stations are used along with streamgaging stations in a regression analysis, however, appropriate weighting of the LFPR stations becomes a problem.

Equivalent years of record, computed using equation 6, could be used to weight the LFPR stations used in the regression analyses, but equivalent years of record is not highly related to the variance of a statistic for a LFPR station. For example, based on a linear regression, the reciprocal of the variance of the 75 -percent duration flow explains about 80 percent of the variation in the years of record for the streamgaging stations used in this study, but it explains only about 17 percent of the variation in the equivalent years of record for the LFPR stations. The other parameters in equation 6 explain most of the remaining variation in equivalent years of record for the LFPR stations. As a result, the variances of a statistic for two LFPR stations can be the same, but their equivalent years of record can be very different.

Equation 6 tends to produce estimates of equivalent years of record that are higher, on average, than the actual years of record for a streamgaging station with the same variance as that of the LFPR station. Because of this, if years of record (actual and equivalent) were to be used alone as the weights in the regression analysis, the LFPR stations would have larger influence in the analysis than the streamgaging stations in relation to the accuracies of the statistics for the stations.

Several potential weighting schemes were tested. The weights used in the regression analyses for the flow-duration statistics and the August median were computed using the equation

$$
W=\frac{N / \operatorname{mean}(N)}{V_{c} / \operatorname{mean}\left(V_{c}\right)}
$$

where $W$ is the weight, $N$ is either the actual years of record for streamgaging stations or the equivalent years of record computed using equation 6 for LFPR stations, and $V_{c}$ is the variance of the streamflow statistic for the station computed from regression equations that relate the variance to the magnitude of the streamflow statistics. A separate regression equation was computed for each statistic. Dividing $N$ and $V_{c}$ by their means removes differences in the scales of the variables, yet maintains their spread. Use of variances computed from regression equations in place of the actual calculated variances resulted in (1) similar variances for a given magnitude of streamflow for both the streamgaging stations and the LFPR stations, (2) a single population of weighted statistics rather than separate populations for streamgaging stations and LFPR stations, (3) elimination of outliers created by some stations having much larger or smaller variances than the others, and (4) correction for non-constant variance of the regression residuals resulting from greater spread of the data for stations with small flows than for stations with large flows.

The weights used in the regression analyses for the 7-day, 2- and 10-year low flows were computed by use of the equation

$$
W=1 /\left(V_{c} / \operatorname{mean}\left(V_{c}\right)\right) .
$$


These weights proved to be adequate for developing the equations for the 7-day, 2and 10-year low flows because the variances of the flow statistics for the LFPR stations and the streamgaging stations used in the analyses were similar, and clustering of the weighted LFPR stations did not occur.

\section{Prediction Intervals}

Prediction intervals at the 90 -percent confidence level can be calculated for estimates obtained from the regression equations. Prediction intervals indicate the uncertainty inherent in use of the equations. Assurance is 90 percent that the true value of the streamflow statistic for an ungaged site will be within the prediction interval.

Tasker and Driver (1988) have shown that a $100(1-\alpha)$ prediction interval for the true value of a streamflow statistic obtained for an ungaged site by use of weighted regression equations corrected for bias can be computed by

$$
\frac{1}{T}\left(\frac{Q}{\mathrm{BCF}}\right)<Q<T\left(\frac{Q}{\mathrm{BCF}}\right),
$$

where $Q$ is the streamflow statistic for the site, $B C F$ is the bias correction factor for the equation, and $T$ is computed as:

$$
T=10^{\left[t_{(\alpha / 2, n-p)} S_{i}\right]} .
$$

In equation $18, t_{(\alpha / 2, n-p)}$ is the critical value from the students t-distribution at alphalevel $\alpha(\alpha=0.10$ for 90 -percent prediction intervals); $n-p$ is the degrees of freedom with $n$ stations used in the regression analysis and $p$ parameters in the equation (the number of basin characteristics plus one); and $S_{i}$ is computed from equation 19 below. Critical values from the students tdistribution are contained in many introductory statistics textbooks.
The value of $S_{i}$ is computed using the equation

$$
S_{i}=\left[\gamma^{2}+x_{i} \mathbf{U} x_{i}^{\prime}\right]^{0.5}
$$

where $\gamma^{2}$ is the model error variance; $x_{i}$ is a row vector of the logarithms of the basin characteristics for site $i$, augmented by a 1 as the first element; $U$ is the covariance matrix for the regression coefficients; and $x_{i}^{\prime}$ is the transpose of $x_{i}$ (Ludwig and Tasker,

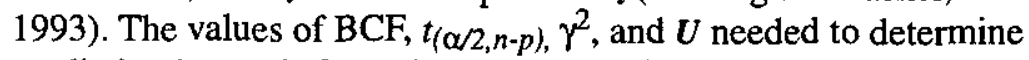
prediction intervals for estimates obtained from the equations in table 4 are presented in table 5.

\section{Example Computations}

The procedure necessary to obtain the estimates is explained by an example computation of the 95 -percent duration low flow for the selected site on the Hawes Brook at Norwood, Mass. (LFPR station number 01104980). First, the necessary basin characteristics for the site are measured from the various GIS data layers. Values for drainage area, mean basin slope, area of stratified drift, total length of streams, and region are $8.64 \mathrm{mi}^{2}, 2.27$ percent, $2.20 \mathrm{mi}^{2}$, $15.5 \mathrm{mi}$, and zero (eastern region $=0$ ), respectively. DRT/TST is computed by dividing the stratified-drift area by the total stream length, and adding a constant of 0.1 , to obtain a value of $0.242 \mathrm{mi}$. Substituting these values into the equation to predict the 95-percent duration low flow (table 4) yields

$$
\begin{gathered}
Q_{95}=0.171(8.64)^{1.120}(2.27)^{0.457}(0.142+0.1)^{0.999} 10^{0.190(0)} \\
=0.675 \mathrm{ft}^{3} / \mathrm{s} .
\end{gathered}
$$

To determine a 90 -percent prediction interval for this estimate, the $\boldsymbol{x}_{i}$ vector is

$$
x_{i}=\left\{1, \log _{10}(8.64), \log _{10}(2.27), \log _{10}(0.242), 0\right\},
$$

the model error variance from table 3 is $\gamma^{2}=0.03302$, and the covariance matrix, $U$, for the 95-percent duration low flow is

$$
\mathbf{U}=\left[\begin{array}{ccccc}
0.154371 & -0.038763 & 0.024844 & 0.178711 & 0.016523 \\
-0.038763 & 0.045306 & -0.026013 & -0.010435 & -0.009947 \\
0.024844 & -0.026013 & 0.215936 & 0.141923 & -0.060291 \\
0.178711 & -0.010435 & 0.141923 & 0.386539 & 0.015753 \\
0.016523 & -0.009947 & -0.060291 & 0.015753 & 0.071684
\end{array}\right]
$$

The standard error of prediction computed from equation 19 is $S_{i}=[0.03302+0.0255]^{0.5}=0.2419$, and $T$ computed from equation 18 is $T=10^{1.654(0.2419)}=2.512$. The 90 -percent prediction interval is estimated from equation 17 as

$$
\begin{gathered}
\frac{1}{2.512}\left(\frac{0.675}{1.017}\right)<Q_{95}<\left(\frac{0.675}{1.017}\right) 2.512, \text { or, } \\
0.264<Q_{95}<1.67
\end{gathered}
$$


Table 5. Values needed to determine 90-percent prediction intervals for estimates obtained from the equations

[Dependent variable: $\mathrm{P}_{x x}$ is the $x x$-percent duration flow; $\mathrm{Q}_{7, y}$ is the 7-day, $y$-year low flow; Aug 50 is the August median flow. BCF: The bias correction factor used in equation 17. $t$ : The critical value from the Students $t$ distribution used in equation $6 . \gamma^{2}$ : The regression model error variance used in equation 19. U: The covariance matrix used in equation 19]

\begin{tabular}{|c|c|c|c|c|}
\hline $\begin{array}{l}\text { Dependent } \\
\text { variable }\end{array}$ & BCF & $t$ & $\gamma^{2}$ & $\mathbf{U}$ \\
\hline$P_{50}$ & 1.003 & 1.662 & 0.00556 & 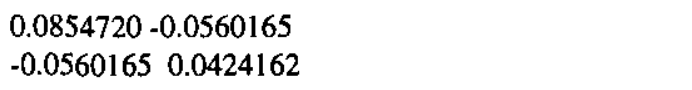 \\
\hline$P_{60}$ & 1.003 & 1.660 & 0.00684 & $\begin{array}{rrr}0.207555 & -0.037260 & 0.210624 \\
-0.037260 & 0.041084 & 0.019092 \\
0.210624 & 0.019092 & 0.326740\end{array}$ \\
\hline$P_{70}$ & 1.005 & 1.657 & 0.00944 & $\begin{array}{rrrr}0.163451 & -0.038750 & 0.179908 & 0.029080 \\
-0.038750 & 0.042838 & 0.005409 & -0.014309 \\
0.179908 & 0.005409 & 0.321624 & 0.064405 \\
0.029080 & -0.014309 & 0.064405 & 0.054811\end{array}$ \\
\hline $\mathrm{P}_{75}$ & 1.006 & 1.656 & 0.01141 & $\begin{array}{rrrr}0.149847 & -0.041152 & 0.157830 & 0.026810 \\
-0.041152 & 0.043708 & 0.002937 & -0.013412 \\
0.157830 & 0.002937 & 0.284083 & 0.059967 \\
0.026810 & -0.013412 & 0.059967 & 0.051001\end{array}$ \\
\hline$P_{80}$ & 1.007 & 1.655 & 0.01360 & $\begin{array}{rrrrrr}0.118875 & -0.038593 & 0.009972 & 0.124035 & 0.019158 \\
-0.038593 & 0.046913 & -0.024336 & -0.006071 & -0.006589 \\
0.009972 & -0.024336 & 0.183858 & 0.099280 & -0.057213 \\
0.124035 & -0.006071 & 0.099280 & 0.284838 & 0.020611 \\
0.019158 & -0.006589 & -0.057213 & 0.020611 & 0.067052\end{array}$ \\
\hline$P_{85}$ & 1.009 & 1.654 & 0.01706 & $\begin{array}{cccccc}0.136687 & -0.034752 & 0.018759 & 0.159536 & 0.018791 \\
-0.034752 & 0.039592 & -0.015993 & -0.005497 & -0.011277 \\
0.018759 & -0.015993 & 0.192606 & 0.135772 & -0.053629 \\
0.159536 & -0.005497 & 0.135772 & 0.366356 & 0.016069 \\
0.018791 & -0.011277 & -0.053629 & 0.016069 & 0.065965\end{array}$ \\
\hline$P_{90}$ & 1.011 & 1.654 & 0.02202 & $\begin{array}{ccccc}0.114435 & -0.032504 & 0.004651 & 0.120264 & 0.019455 \\
-0.032504 & 0.039590 & -0.013401 & -0.001500 & -0.012562 \\
0.004651 & -0.013401 & 0.183669 & 0.112504 & -0.053751 \\
0.120264 & -0.001500 & 0.112504 & 0.300342 & 0.018315 \\
0.019455 & -0.012562 & -0.053751 & 0.018315 & 0.068902\end{array}$ \\
\hline$P_{95}$ & 1.017 & 1.654 & 0.03302 & $\begin{array}{rrrrrr}0.154371 & -0.038763 & 0.024844 & 0.178711 & 0.016523 \\
-0.038763 & 0.045306 & -0.026013 & -0.010435 & -0.009947 \\
0.024844 & -0.026013 & 0.215936 & 0.141923 & -0.060291 \\
0.178711 & -0.010435 & 0.141923 & 0.386539 & 0.015753 \\
0.016523 & -0.009947 & -0.060291 & 0.015753 & 0.071684\end{array}$ \\
\hline $\mathrm{P}_{98}$ & 1.028 & 1.655 & 0.05447 & $\begin{array}{rrrrr}0.146494 & -0.039856 & 0.024356 & 0.169566 & 0.019479 \\
-0.039856 & 0.047367 & -0.027332 & -0.010335 & -0.009705 \\
0.024356 & -0.027332 & 0.220827 & 0.140684 & -0.063551 \\
0.169566 & -0.010335 & 0.140684 & 0.374380 & 0.017814 \\
0.019479 & -0.009705 & -0.063551 & 0.017814 & 0.073700\end{array}$ \\
\hline$P_{99}$ & 1.031 & 1.656 & 0.06196 & $\begin{array}{rrrrr}0.155123 & -0.041195 & 0.027513 & 0.180199 & 0.019040 \\
-0.041195 & 0.050395 & -0.033160 & -0.011029 & -0.008574 \\
0.027513 & -0.033160 & 0.251192 & 0.159684 & -0.067073 \\
0.180199 & -0.011029 & 0.159684 & 0.402732 & 0.016396 \\
0.019040 & -0.008574 & -0.067073 & 0.016396 & 0.074477\end{array}$ \\
\hline
\end{tabular}


Table 5. Values needed to determine 90-percent prediction intervals for estimates obtained from the equations-Continued

\begin{tabular}{|c|c|c|c|c|c|}
\hline $\begin{array}{c}\text { Dependent } \\
\text { variable }\end{array}$ & BCF & $t$ & $\gamma^{2}$ & $v$ & \\
\hline$Q_{7,2}$ & 1.019 & 1.657 & 0.03810 & $\begin{array}{ccccc}0.158738 & -0.046861 & 0.027795 & 0.181537 & 0.018992 \\
-0.046861 & 0.058491 & -0.031551 & -0.005478 & -0.006372 \\
0.027795 & -0.031551 & 0.223389 & 0.145159 & -0.065982 \\
0.181537 & -0.005478 & 0.145159 & 0.407552 & 0.016782 \\
0.018992 & -0.006372 & -0.065982 & 0.016782 & 0.072663\end{array}$ & . \\
\hline$Q_{7,10}$ & 1.036 & 1.658 & 0.07122 & $\begin{array}{ccccc}0.165118 & -0.044475 & 0.027261 & 0.193316 & 0.022249 \\
-0.044475 & 0.054996 & -0.029584 & -0.004231 & -0.008217 \\
0.027261 & -0.029584 & 0.248129 & 0.168050 & -0.069078 \\
0.193316 & -0.004231 & 0.168050 & 0.452158 & 0.019891 \\
0.022249 & -0.008217 & -0.069078 & 0.019891 & 0.077525\end{array}$ & \\
\hline Aug $_{50}$ & 1.009 & 1.656 & 0.01785 & $\begin{array}{ccccc}0.148786 & -0.037505 & 0.015571 & 0.169781 & 0.024324 \\
-0.037505 & 0.039103 & -0.017540 & -0.011161 & -0.011969 \\
0.015571 & -0.017540 & 0.192826 & 0.127179 & -0.053990 \\
0.169781 & -0.011161 & 0.127179 & 0.364703 & 0.024260 \\
0.024324 & -0.011969 & -0.053990 & 0.024260 & 0.069070\end{array}$ & \\
\hline
\end{tabular}

Thus, the most probable estimate of the 95-percent duration low flow for station 01104980 is $0.675 \mathrm{ft}^{3} / \mathrm{s}$, and there is a 90 -percent probability that the true value of $Q_{95}$ is between 0.264 and $1.67 \mathrm{ft}^{3} / \mathrm{s}$.

\section{Limitations for Use of the Equations}

Regression equations can be used to estimate streamflow statistics for ungaged sites with natural flow conditions in most of Massachusetts. If the equations are used to estimate streamflow statistics for sites where human influences on streamflows are present, such as water-supply withdrawals and dam regulations, the user should adjust the estimates for the human influences.

Applicability of the equations is limited by the range of data used to develop the equations and by the accuracy of the estimates. Ranges of applicability for each equation are shown in table 6 . The measures of model adequacy listed in table 4 , and the prediction intervals calculated using equations 17 to 19 , indicate potential errors that can be expected when basin characteristics for the selected sites are within the ranges of those for the sites used in the regression analyses.

The equations generally are not applicable in almost all of the South Coastal Shore subbasin of the South Coastal Basin, the eastern part of the Buzzards Bay Basin, Cape Cod, and the islands of Martha's Vineyard and Nantucket. These areas, which are almost entirely underlain by coarse-grained stratified-drift deposits, are not adequately represented by sites in the regression analyses. Streams in these areas commonly have ground-water drainage divides that are not coincident with topographic drainage divides. Estimates obtained by use of the regression equations for selected sites in these areas could have substantial errors.

\section{World Wide Web Application for Use of the Equations}

The automated procedure for measuring basin characteristics, described in the Data Base Development section, was modified for use in a World Wide Web (Web) application that serves streamflow statistics for user-selected stream sites. The Web application (http://ma.water.usgs.gov/streamstats) was

Table 6. Ranges of basin characteristics used to develop the regression equations

[mi, mile; $\mathrm{mi}^{2}$, square mile; --, not applicable]

\begin{tabular}{clrccc}
\hline Basin characteristic & $\begin{array}{c}\text { Name } \\
\text { in } \\
\text { equations }\end{array}$ & $\begin{array}{c}\text { Mini- } \\
\text { mum }\end{array}$ & Mean & $\begin{array}{c}\text { Maxi- } \\
\text { mum }\end{array}$ \\
\hline Drainage area $\left(\mathrm{mi}^{2}\right) \ldots \ldots \ldots \ldots \ldots \ldots$. & $D A$ & 1.61 & 14,9 & 149 \\
Total basin stream length $(\mathrm{mi}) \ldots$ & -- & 1.79 & 27.9 & 319 \\
Mean basin slope (percent) ....... & $S L$ & .32 & 5.28 & 24.6 \\
Area of stratified drift per & $D R / S T$ & .00 & .144 & 1.29 \\
unit stream length $\left(\mathrm{mi}^{2} / \mathrm{mi}\right) \ldots$ & & & & \\
Region .................................. & REG & 0 & $\ldots$ & 1 \\
\hline
\end{tabular}


developed jointly by the USGS and MassGIS and it incorporates a data base of previously published streamflow statistics as well as the automated procedure for measuring basin characteristics and obtaining regression equation estimates of streamflow statistics for ungaged sites. The previously developed automated procedure was translated from an AML script to an Avenue script (Environmental Systems Research Institute, Inc.,.1996a) to enable it to function in the Web application, and a subroutine was added to solve the regression equations and calculate the prediction intervals presented in this report.

A user interface was developed for the application by Syncline, Inc., of Cambridge, Mass., under contract to the USGS. The user interface is a Java applet that delivers interactive maps to users using the ArcView Internet Map Server (Environmental Systems Research Institute, Inc., 1996-97) software extension to ArcView (Environmental Systems Research Institute, Inc., 1996b). Users locate sites on streams for which they want streamflow statistics by . using the interface to add various digital map data and to move around and zoom in to the area of interest. Users can obtain streamflow statistics for a datacollection station by selecting its location marker on the map. The data base provides any previously determined streamflow statistics for the selected site, including peak-flow statistics not discussed in this report. Users can also obtain estimated streamflow statistics for any location along a stream (within the areas of applicability) by running the automated procedure. Further documentation for the Web application is provided in a fact sheet (Ries and others, 2000), and in help pages and other links within the application.

\section{COMBINING ESTIMATES DETERMINED BY DIFFERENT METHODS}

Improved estimates of streamflow statistics for LFPR stations can be obtained by combining the weighted correlation-based estimates determined from equation 3 with those obtained from the regression equations. The estimates are weighted by the reciprocals of their standard errors and averaged by using the equation

$$
Q_{S, U_{w^{\prime}}}=\frac{\left(Q_{S, U_{w}} /\left(S E_{w}\right)\right)+\left(Q_{S, U_{r}} /\left(S E_{r}\right)\right)}{\left(1 /\left(S E_{w}\right)\right)+\left(1 /\left(S E_{r}\right)\right)}
$$

where the terms are as previously defined, except $Q_{S, U}$ is the regression equation estimate of streamflow statistic $S$ for the LFPR station and $S E_{r}$ is the standard error of the regression equation estimate determined for the station from (a) equation 19, (b) the regression equation standard error of estimate from table 4 if the station was used in the regression analysis, or (c) the regression equation standard error of prediction from table 4 if the station was not used in the regression analysis. The standard error of estimate determined from equation 19 will provide the most precise weighted estimate, but it is difficult to calculate. Use of the standard errors from table 4 should be adequate for most needs.

When an ungaged site is on the same stream as a streamgaging or LFPR station and the drainage area for the ungaged site is between 0.3 and 1.5 times the drainage area of the streamgaging or LFPR station, improved estimates of the streamflow statistics for the ungaged site can be obtained using a weighting procedure to combine the estimates from regression equations with the streamflow statistics determined for the data-collection station. The procedure is modified from that of Pope and Tasker (1999, p. 16) and Choquette (1988, p. 42). The estimates are combined by first computing the correction factor,

$$
C_{D}=Q_{S, D_{w}} / Q_{S, D_{r}},
$$

where $C_{D}$ is the correction factor for $D$, the datacollection station (streamgaging or LFPR station), $Q_{S, D_{w}}$ is the streamflow statistic $S$ determined from available data for the data-collection station, and $Q_{S, D_{r}}$ is the streamflow statistic determined from the regression equation. Next, a correction factor, $C_{U}$, is determined for the ungaged site. If the drainage area for the ungaged site $(D A U)$ is less than 1.5 times larger than the drainage area for the data-collection station $\left(D A_{D}\right)$, use the equation

$$
C_{U}=C_{D}-\frac{\Delta D A\left(C_{D}-1\right)}{0.5 D A_{D}},
$$

where $\triangle D A$ is the absolute value of the difference between $D A_{U}$ and $D A_{D}$. If $D A U$ is smaller than and within 0.3 times $D A D$, use the equation

$$
C_{U}=C_{D}-\frac{\Delta D A\left(C_{D}-1\right)}{0.7 D A_{D}}
$$


The effect of the correction factor is that more weight is given to the streamflow statistic for the datacollection station the closer the ungaged site is to it. If $D A_{U}$ is greater than 1.5 times or less than 0.3 times $D A D$, no correction is necessary.

\section{SUMMARY}

This report is the sixth and final report of the Basin Yield series of reports prepared in cooperation with the Massachusetts Department of Environmental Management. The report provides methods for estimating low-flow statistics for Massachusetts streams. Different methods are provided depending on whether the location of interest is a streamgaging station, a low-flow partial-record station, or an ungaged site where no data are available. Standard USGS methods and computer software are described for determining flow-duration and low-flow frequency statistics for streamgaging stations. Two methods are described for determining August median flows for streamgaging stations. References are provided to reports that describe methods for extending or augmenting records for streamgaging stations with short records to reflect long-term conditions.

Mathematical and graphical correlation methods are presented for estimating low-flow statistics for lowflow partial-record stations. The MOVE.1

mathematical method is recommended for use when the relation between measured flows at the low-flow partial-record (LFPR) station and daily mean flows at a nearby, hydrologically similar streamgaging station is linear. A widely used graphical method is recommended when this relation is curved. The report contains equations for computing the variance and equivalent years of record for estimates of low-flow statistics determined using the two methods. Estimates of low-flow statistics for LFPR stations can be improved by combining estimates determined from multiple index stations. The report contains equations for calculating combined estimates and the variances, standard errors, and equivalent years of record of these estimates.

Two methods are presented for estimating lowflow statistics for ungaged sites where no data are available - the drainage-area ratio method and use of regression equations. The drainage-area ratio method is applied by dividing the streamflow statistics for a nearby, hydrologically similar index streamgaging station by the drainage area for the station, then multiplying these values by the drainage area of the ungaged site of interest to obtain estimates of the streamflow statistics for the site. A comparison of streamflow statistics estimated using the drainage-area ratio method and regression equations to those determined from available data for 25 LFPR and 8 streamgaging stations in 5 Massachusetts river basins indicated that drainage-area ratio estimates generally are as accurate or more accurate than regression estimates when the drainage-area ratio for an ungaged site is between 0.3 and 1.5 times the drainage area of the index data-collection site. Regression equations can be used to obtain estimates for most ungaged sites.

Regression equations were developed to estimate the natural, long-term 99-, 98-, 95-, 90-, 85-, 80-, 75-, $70-, 60-$, and 50 -percent duration flows; the 7-day, 2-year and the 7-day, 10-year low flows; and the August median flow for ungaged sites in Massachusetts. As many as 37 streamgaging stations and 107 LFPR stations were included in the analyses. Streamflow statistics and basin characteristics for these stations were presented in the report. The number of stations used to develop the individual equations ranged from 87 for the 50-percent duration flow to 133 for the 98-percent duration flow. The gaging stations had from 2 to 81 years of record, with a mean record length of 37 years. The LFPRs had from 8 to 36 streamflow measurements, with a median of 14 measurements.

All physical characteristics of the basins for the stations used in the regression analyses were determined from digital data bases using GIS computer software. Drainage area, the area of stratified-drift deposits per unit of stream length plus 0.1 , mean basin slope, and an indicator variable that was 0 in the eastern region and 1 in the western region of Massachusetts were used in 9 of the 13 final regression equations. Mean basin slope was not used in the equations for the 50- through 75-percent duration flows. The indicator variable for region was not used in the equations for the 50 - and 60-percent duration flows. Only drainage area was used in the equation for the 50-percent duration flow. All basin characteristics that appeared in the equations were positively correlated to the streamflow statistics used as the dependent variables.

The equations were developed by use of weighted-least-squares regression analyses. Weights in the analyses were assigned proportional to the actual 
(for streamgaging stations) or equivalent (for LFPR stations) years of record and inversely proportional to the variances of the streamflow statistics for the stations. Standard errors of prediction ranged from 70.8 to 17.6 percent for the equations to predict the 7-day, 10-year low flow and 50-percent duration flow, respectively. The proportion of the variation in the dependent variables that is explained by the independent variables $\left(R_{a d j}^{2}\right)$ ranged from 84.4 to 98.1 percent for the 7-day, 10-year low flow and 50-percent duration flow, respectively. The equations are not applicable in the Southeast Coastal region of the State, or where basin characteristics for the selected ungaged site are outside the ranges of those for the stations used in the regression analyses. If the equations are used to estimate streamflow statistics for sites where human influences on streamflows are present, such as watersupply withdrawals and dam regulations, the user should adjust the estimates for the human influences.

A World Wide Web application is described that enables users to obtain streamflow statistics for most stream locations in Massachusetts. The Web application provides streamflow statistics for datacollection stations from a data base and for ungaged sites by measuring the necessary basin characteristics for a selected site and solving the regression equations. Output provided by the Web application for ungaged sites includes a map of the drainage-basin boundary determined for the site, the measured basin characteristics, the streamflow statistics estimated from the equations in this report, and 90-percent prediction intervals for the estimates.

Finally, the report presents an equation that can be used to combine regression and correlation estimates to obtain improved estimates of the streamflow statistics for LFPR stations. The report also presents equations that can be used to combine regression and drainage-area ratio estimates to obtain improved estimates of the streamflow statistics for ungaged sites. These equations are applicable when the drainage area of the ungaged site is between 0.3 and 1.5 times the drainage area of a streamgaging or LFPR station.

\section{REFERENCES CITED}

Bent, G.C., 1995, Streamflow, ground-water recharge and discharge, and characteristics of surficial deposits in

- Buzzards Bay Basin, southeastern Massachusetts: U.S. Geological Survey Water-Resources Investigations Report 95-4234, $56 \mathrm{p}$.

Bisese, J.A., 1995, Methods for estimating the magnitude and frequency of peak discharges of rural, unregulated stream in Virginia: U.S. Geological Survey WaterResources Investigations Report 94-4148, 70 p., 1 pl.

Bradu, D. and Mundlak, Y., 1970, Estimation in lognormal linear models: Journal of the American Statistical Association, v. 65, no. 329, p.198-211.

Bratton, Lisa, and Parker, G.W., 1995, Estimated availability of water from stratified-drift aquifers in the Concord River Basin, Massachusetts: U.S. Geological Survey Water-Resources Investigations Report 94-4256, 35 p.

Cervione, M.A., Jr., 1982, Streamflow information for Connecticut with application to land-use planning: Connecticut Department of Environmental Protection Bulletin 35, p. 16.

Choquette, A.F., 1988, Regionalization of peak discharges for streams in Kentucky: U.S. Geological Survey Water-Resources Investigations Report 88-4209, 105 p., 1 pl.

Cleveland, W.S., 1979, Robust locally weighted regression and smoothing scatterplots: Journal of the American Statistical Association, v. 74, p. 829-836.

Cohn, T.A., DeLong, L.L., Gilroy, E.J., Hirsch, R.M., and Wells, D.K., 1989, Estimating constituent loads: WaterResources Research, v. 25, no. 5, p. 937-942.

deLima, Virginia, 1991, Stream-aquifer relations and yield of stratified-drift aquifers in the Nashua River Basin, Massachusetts: U.S. Geological Survey WaterResources Investigations Report 88-4147, 47 p.

Dingman, S.L., 1978, Synthesis of flow-duration curves for unregulated streams in New Hampshire: WaterResources Bulletin, v. 14, no. 6, p. 1481-1502.

Duan, Naihua, 1983, Smearing estimate: a non-parametric retransformation method: Journal of the American Statistical Association, v. 78, no. 383, p. 605-610.

Environmental Systems Research Institute, Inc., 1990, Understanding GIS, the ARC/INFO method: Redlands, Calif., 10 chaps., various pagination.

1996a, Avenue: Customization and application development for ArcView GIS: Redlands, Calif., 239 p. 1996b, Getting to know ArcView: New York, N.Y., John Wiley, various pagination.

1996-1997, ArcView Internet Map Server: Redlands, Calif., $60 \mathrm{p}$. 
Fennessey, Neil, and Vogel, R.M., 1990, Regional flowduration curves for ungauged sites in Massachusetts: Journal of Water Resources Planning and Management, v. 116 , no. 4 , p. $530-549$.

Ferguson, R.I., 1986, River loads underestimated by rating curves: Water Resources Research, v. 22, no. 1, p. 7476.

Flynn, K.M., Hummel, P.R., Lumb, A.M., and Kittle, J.L., Jr., 1995, User's manual for ANNIE, version 2, a computer program for interactive hydrologic data management: U.S. Geological Survey Water-Resources Investigations Report 95-4085, $211 \mathrm{p}$.

Friesz, P.J., 1996, Geohydrology of stratified drift and streamflow in the Deerfield River Basin: U.S. Geological Survey Water-Resources Investigations Report 96-4115, 49 p., 1 pl.

Gadoury, R.A., Socolow, R. S., Girouard, G.G., and Ramsbey, L.R., 1995, Water resources data for Massachusetts and Rhode Island, water year 1994: U.S. Geological Survey Water-Data Report MA-RI-94-1, $314 \mathrm{p}$.

Gilroy, E.J., Hirsch, R.M., and Cohn, T.A., 1990, Mean square error of regression-based constituent transport estimates: Water Resources Research, v. 26, no. 9, p. 2069-2077.

Hardison, C.H., 1969, Accuracy of streamflow measurements: U.S. Geological Survey Professional Paper 650-D, p. 210-214.

Hardison, C.H., and Moss, M.E., 1972, Accuracy of lowflow characteristics estimated by correlation of baseflow measurements, in Manual of Hydrology-Part 2. Low-Flow Techniques: U.S. Geological Survey WaterSupply Paper 1542-B, p. 35-55.

Hansen, B.P., and Lapham, W.W., 1992, Geohydrology and simulated ground-water flow, Plymouth-Carver aquifer, southeastern Massachusetts: U.S. Geological Survey Water-Resources Investigations Report 90-4204, 69 p., 2 pls.

Hirsch, R.M., 1982, A comparison of four streamflow record extension techniques: Water Resources Research, v. 18, no. 4., p. 1081-1088.

Iman, R.L., and Conover, W.J., 1983, A modern approach to statistics: New York, John Wiley, 497 p.

Johnson, C.G., 1970, A proposed streamflow data program for central New England: U.S. Geological Survey Open-File Report, $38 \mathrm{p}$.

Klinger, A.R., 1996, Estimated short-term yields of and quality of ground water in stratified-drift aquifer areas in the Neponset River Basin, Massachusetts: U.S. Geological Survey Water-Resources Investigations Report 93-4142, 30 p.

Koch, R.W., and Smillie, G.M., 1986, Bias in hydrologic prediction using log-transformed regression models: Water Resources Bulletin, v. 22, no. 5, p. 717-723.
Koltun, G.F., and Roberts, J.W., 1990, Techniques for estimating flood-peak discharges of rural, unregulated stream in Ohio: U.S. Geological Survey WaterResources Investigations Report 89-4126, 68 p., 1 pl.

Koltun, G.F., and Schwartz, R.R., 1986, Multiple-regression equations for estimating low flows at ungaged stream sites in Ohio: U.S. Geological Survey Water-Resources Investigations Report 86-4354, 39 p., 6 pls.

Ku, H.F., Randall, A.D., and MacNish, R.D., 1975, Streamflow in the New York part of the Susquehanna River Basin: New York State Department of Environmental Conservation Bulletin 71, 130 p.

Kulik, B.H., 1990, A method to refine the New England Aquatic Base Flow Policy: Rivers, v. 1, no. 1, p. 8-22.

Lapham, W.W., 1988, Yield and quality of ground water from stratified-drift aquifers, Taunton River Basin, Massachusetts: U.S. Geological Survey WaterResources Investigations Report 86-4053, 69 p., 2 pls.

Loaiciga, H.A., 1989, Variability of empirical flow quantiles: Journal of Hydraulic Engineering, American Society of Civil Engineers, 115(1), p. 82-100.

Ludwig, A.H., and Tasker, G.D., 1993, Regionalization of low-flow characteristics of Arkansas streams: U.S. Geological Survey Water-Resources Investigations Report 93-4013, 19 p.

Lumb, A.M., Kittle, J.L., Jr., and Flynn, K.M., 1990, Users manual for ANNIE, a computer program for interactive hydrologic analyses and data management: U.S. Geological Survey Water-Resources Investigations Report 89-4080, 236 p.

Lumia, Richard, 1991, Regionalization of flood discharges for rural, unregulated streams in New York, excluding Long Island: U.S. Geological Survey Water-Resources Investigations Report 90-4197, 119 p., 2 pls.

Male, J.W., and Ogawa, Hisashi, 1982, Low flow of Massachusetts streams: Amherst, Mass., University of Massachusetts, Water Resources Research Center Publication 125, $152 \mathrm{p}$.

Minitab, Inc., 1998a, User's guide 1-Data, graphics, and macros: State College, Penn, 33 chapters, various pagination.

Minitab, Inc., 1998b, User's guide 2-Data analysis and quality tools: State College, Penn, 22 chapters, various pagination.

Montgomery, D.C., and Peck, E.A., 1982, Introduction to linear regression analysis: New York, John Wiley, $504 \mathrm{p}$.

Myette, C.F., and Simcox, A.C., 1992, Water resources and aquifer yields in the Charles River Basin, Massachusetts: U.S. Geological Survey WaterResources Investigations Report 88-4173, Revised 1991, $50 \mathrm{p}$. 
Neter, John, Wasserman, William, and Kutner, M.H., 1985, Applied linear statistical models: Homewood, Illinois, Irwin, $1127 \mathrm{p}$.

Olimpio, J.C., and deLima, Virginia, 1984, Ground-water resources of the Mattapoisett River Valley, Plymouth County, Massachusetts: U.S. Geological Survey WaterResources Investigations Report 84-4043, 83 p.

Parker, G.W., 1977, Methods for determining selected flow characteristics for streams in Maine: U.S. Geological Survey Open-File Report 78-871, 31 p.

Persky, J.H., 1993, Yields and water quality of stratified-drift aquifers in the Southeast Coastal Basin, Cohassett to Kingston, Massachusetts: U.S. Geological Survey Water-Resources Investigations Report 91-4112, 47 p., $2 \mathrm{pl}$.

Pope, B.F., and Tasker, G.D., 1999, Estimating the magnitude and frequency of floods in rural basin of North Carolina: U.S. Geological Survey WaterResources Investigations Report 99-4114, 44 p.

Randall, A.D., 1996, Mean annual runoff, precipitation, and evapotranspiration in the glaciated northeastern United Statès, 1951-80: U.S. Geological Survey Open-File Report 96-395, 2 pls., scale 1:1,000,000.

Ries, K.G., III, 1994a, Estimation of low-flow duration discharges in Massachusetts: U.S. Geological Survey Water-Supply Paper 2418, 50 p. 1994b, Development and application of generalizedleast-squares regression models to estimate low-flow duration discharges in Massachusetts: U.S. Geological Survey Water-Resources Investigations Report 94$4155,33 \mathrm{p}$.

1997, August median streamflows in Massachusetts:

U.S. Geological Survey Water-Resources Investigations Report 97-4190, 27 p.

1999, Streamflow measurements, basin characteristics, and streamflow statistics for low-flow partial-record stations operated in Massachusetts from 1989 through 1996: U.S. Geological Survey Water-Resources Investigations Report 99-4006, $162 \mathrm{p}$. 2000, Obtaining streamflow statistics for Massachusetts streams on the World Wide Web: U.S. Geological Survey Fact Sheet 104-00, 4 p.

Riggs, H.C., 1972, Low-flow investigations: U.S. Geological Survey Techniques of Water-Resources Investigations, book 4, chap. B1, $18 \mathrm{p}$.

Risley, J.C., 1994, Estimating the magnitude and frequency of low flows of streams in Massachusetts: U.S. Geological Survey Water-Resources Investigations Report 94-4100, 29 p.

Ritzi, Charles, and Associates, 1987, Computation of USFWS Aquatic Base Flow for Regulated Streams. Winthrop, Maine, $15 \mathrm{p}$.
Searcy, J.K., 1959, Flow-duration curves, Manual of hydrology-Part 2. Low-flow techniques: U.S. Geological Survey Water-Supply Paper 1542-A, p. 133.

Socolow, R.S., Comeau, L.Y., Casey, R.G., and Ramsbey, L.R., 1996, Water resources data for Massachusetts and Rhode Island, water year 1995: U.S. Geological Survey Water-Data Report MA-RI-95-1, 428 p.

Socolow, R.S., Murino, Domenic, Jr., Casey, R.G., and Ramsbey, L.R., 1997, Water resources data for Massachusetts and Rhode Island, water year 1996: U.S. Geological Survey Water-Data Report MA-RI-96-1, $367 \mathrm{p}$.

Stedinger, J.R., and Tasker, G.D., 1985, Regional hydrologic analysis 1 . Ordinary, weighted, and generalized least squares compared: Water Resources Research, v. 21, no. 9, p. 1421-1432.

Stedinger, J.R., and Thomas, W.O., 1985, Low-flow frequency estimation using base-flow measurements: U.S. Geological Survey Open-File Report 85-95, p. 22.

Tasker, G.D., 1972, Estimating low-flow characteristics of streams in southeastern Massachusetts from maps of ground water availability, in Geological Survey Research, 1972: U.S. Geological Survey Professional Paper 800-D, p. D217-D220.

1975, Combining estimates of low-flow characteristics of streams in Massachusetts and Rhode Island: Journal of Research of the U.S. Geological Survey, v. 3, no. 1, p. 107-112.

1989, An operational GLS model for hydrologic regression: Journal of Hydrology, v. iii, p. 361-375.

Tasker, G.D., and Driver, N.E., 1988, Nationwide regression models for predicting urban runoff water quality at unmonitored sites: Water Resources Bulletin, v. 24, no. 5, p. 1091-1101.

Tasker, G.D., and Stedinger, J.R., 1989, An operational GLS model for hydrologic regression: Journal of Hydrology, v. 3, p. 361-375.

Thomas, M.P., 1966, Effect of glacial geology upon the time distribution of streamflow in eastern and southeastern Connecticut: U.S. Geological Survey Professional Paper 550-B, p. B209-B212.

U.S. Commerce Department, National Oceanic and Atmospheric Administration, 1989, Climatological data, annual summary, New England, v. 101, no. 13, $51 \mathrm{p}$.

1994, Climatological data, annual summary, New England, v. 106, no. 13, 52 p.

U.S. Fish and Wildlife Service, 1981, Interim regional policy for New England stream flow recommendations: Region I, Concord, NH: U.S. Fish and Wildlife Service, $3 \mathrm{p}$. 
Vogel, R.M., and Fennessey, N.M, 1994, Flow-duration curves. I: New interpretation and confidence intervals: Journal of Water Resources Planning and Management, v. 120 , no. 4 , p. $485-504$.

Vogel, R.M., and Kroll, C.N., 1989, Low-flow frequency analysis using probability-plot correlation coefficients: Journal of Water Resources Planning and Management, v. 115 , no. 3, p.338-357.

1990, Generalized low-flow frequency relationships for ungaged sites in Massachusetts: Water Resources Bulletin, v. 26, no. 2, p. 241-253.
1991, The value of streamflow record augmentation procedures in low-flow and flood-flow frequency analysis: Journal of Hydrology, v. 125, pp. 259-276

Wandle, S.W., Jr., and Randall, A.D., 1994, Effects of surficial geology, lakes and swamps, and annual water availability on low flows of streams in central New England, and their use in low-flow estimation: U.S. Geological Survey Water-Resources Investigations Report 93-4092, 57 p. 
TABLES 7-10 

Table 7. Low-flow statistics estimated using available data, the drainage-area ratio method, and regression equations; and absolute percent differences between the data-based estimates and estimates from the drainage-area ratio method and regression equations for stations used to analyze to applicability of the drainage-area ratio method for estimating low-flow statistics for ungaged Massachusetts streams

[Station No.: Station numbers for streamgaging stations are in bold in the station number column. Low-flow statistic: Low-flow statistics are the 99-, 98-, and 95-percent duration and the August median flows, in cubic feet per second $\left(\mathrm{ft}^{3} / \mathrm{s}\right)$; average is the average of the four streamflow statistics. Data-based estimates: Data-based estimates were calculated for streamgaging stations from the daily mean flows for the period of record and estimated for low-flow partial-record stations by correlating measured flows to same-day mean flows at the index streamgaging station.]

\begin{tabular}{|c|c|c|c|c|c|c|c|c|c|}
\hline \multirow{2}{*}{$\begin{array}{c}\text { Station } \\
\text { No. }\end{array}$} & \multirow{2}{*}{$\begin{array}{l}\text { Index } \\
\text { stream- } \\
\text { gaging } \\
\text { station } \\
\text { No. }\end{array}$} & \multirow{2}{*}{$\begin{array}{l}\text { Drainage- } \\
\text { area } \\
\text { ratio }\end{array}$} & \multirow{2}{*}{$\begin{array}{l}\text { Low-flow } \\
\text { statistic }\end{array}$} & \multirow{2}{*}{$\begin{array}{c}\text { Data-based } \\
\text { estimate } \\
\left(\mathrm{ft}^{3} / \mathrm{s}\right)\end{array}$} & \multicolumn{2}{|c|}{$\begin{array}{c}\text { Drainage-area ratio } \\
\text { method }\end{array}$} & \multicolumn{2}{|c|}{ Regression equations } & \multirow[b]{2}{*}{ Remarks } \\
\hline & & & & & $\begin{array}{c}\text { Estimate } \\
\left(\mathrm{ft}^{3} / \mathrm{s}\right)\end{array}$ & $\begin{array}{l}\text { Absolute } \\
\text { percent } \\
\text { difference }\end{array}$ & $\begin{array}{c}\text { Estimate } \\
\left(\mathrm{tt}^{3} / \mathrm{s}\right)\end{array}$ & $\begin{array}{c}\text { Absolute } \\
\text { percent } \\
\text { difference }\end{array}$ & \\
\hline \multicolumn{10}{|c|}{ Squannacook River Basin (subbasin of Nashua River Basin) } \\
\hline \multirow[t]{5}{*}{01095928} & 01096000 & 0.092 & 99 & 0.026 & 0.60 & 2,223 & 0.38 & 1,369 & \multirow{10}{*}{ - } \\
\hline & & & 98 & .046 & .72 & 1,472 & .44 & 852 & \\
\hline & & & 95 & .15 & 1.04 & 612 & .62 & 327 & \\
\hline & & . & August & .86 & 1.83 & 114 & 1.00 & 16.5 & \\
\hline & & & Average & .27 & 1.05 & 1,105 & .61 & 641 & \\
\hline \multirow[t]{5}{*}{01095930} & 01096000 & .192 & 99 & .60 & 1.26 & 110 & 1.08 & 80.5 & \\
\hline & & & 98 & .76 & 1.51 & 99.7 & 1.27 & 67.5 & \\
\hline & & & 95 & 1.22 & 2.18 & 78.7 & 1.70 & 39.1 & \\
\hline & & & August & 2.53 & 3.83 & 51.4 & 2.52 & 0.4 & \\
\hline & & & Average & 1.28 & 2.19 & 85.0 & 1.64 & 46.9 & \\
\hline \multirow[t]{5}{*}{01095977} & 01096000 & .688 & 99 & 2.58 & 4.54 & 76.0 & 4.38 & 69.9 & \\
\hline & & & 98 & 3.22 & 5.44 & 68.9 & 5.36 & 66.6 & \\
\hline & & & 95 & 5.08 & 7.84 & 54.3 & 7.02 & 38.1 & \\
\hline & & & August & 10.2 & 13.8 & 35.3 & 11.0 & .7 .5 & \\
\hline & & & Average & 5.27 & 7.90 & 58.6 & 6.93 & 45.5 & \\
\hline \multirow[t]{5}{*}{01095990} & 01096000 & .895 & 99 & 5.05 & 5.90 & 16.8 & 5.89 & 16.6 & \\
\hline & & & 98 & 6.10 & 7.07 & 15.9 & 7.33 & 20.2 & \\
\hline & & & 95 & 8.97 & 10.2 & 13.7 & 9.56 & 6.6 & \\
\hline & & & August & 16.2 & 17.9 & 10.5 & 15.3 & 5.9 & \\
\hline & & & Average & 9.08 & 10.3 & 14.2 & 9.50 & 12.3 & \\
\hline
\end{tabular}


Table 7. Low-flow statistics estimated using available data, the drainage-area ratio method, and regression equations; and absolute percent differences between the data-based estimates and estimates from the drainage-area ratio method and regression equations for stations used to analyze to applicability of the drainagearea ratio method for estimating low-flow statistics for ungaged Massachusetts streams-Continued

\begin{tabular}{|c|c|c|c|c|c|c|c|c|c|}
\hline \multirow{2}{*}{$\begin{array}{l}\text { Station } \\
\text { No. }\end{array}$} & \multirow{2}{*}{$\begin{array}{l}\text { Index } \\
\text { stream- } \\
\text { gaging } \\
\text { station } \\
\text { No. }\end{array}$} & \multirow{2}{*}{$\begin{array}{l}\text { Drainage- } \\
\text { area } \\
\text { ratio }\end{array}$} & \multirow{2}{*}{$\begin{array}{l}\text { Low-flow } \\
\text { statistic }\end{array}$} & \multirow{2}{*}{$\begin{array}{l}\text { Data-based } \\
\text { estimate } \\
\left(\mathrm{ft}^{3} / \mathrm{s}\right)\end{array}$} & \multicolumn{2}{|c|}{$\begin{array}{l}\text { Drainage-area ratio } \\
\text { method }\end{array}$} & \multicolumn{2}{|c|}{ Regression equations } & \multirow[b]{2}{*}{ Remarks } \\
\hline & & & & & $\begin{array}{c}\text { Estimate } \\
\left(\mathrm{ft}^{3} / \mathrm{s}\right)\end{array}$ & $\begin{array}{c}\text { Absolute } \\
\text { percent } \\
\text { difference }\end{array}$ & $\begin{array}{c}\text { Estimate } \\
\left(\mathrm{ft}^{3} / \mathrm{s}\right)\end{array}$ & $\begin{array}{c}\text { Absolute } \\
\text { percent } \\
\text { difference }\end{array}$ & \\
\hline \multicolumn{10}{|c|}{ Squannacook River Basin (subbasin of Nashua River Basin)—Continued } \\
\hline \multirow[t]{5}{*}{01096000} & -- & 1.000 & 99 & 6.60 & -. & -- & 7.03 & 6.5 & \\
\hline & & & 98 & 7.90 & -- & -- & 8.86 & 12.2 & \\
\hline & & & 95 & 11.4 & -- & -- & 11.4 & 0.1 & \\
\hline & & . & August & 20.0 & - & - & 17.9 & 10.4 & \\
\hline & & & Average & 11.5 & - & -- & 11.3 & 7.3 & \\
\hline \multirow[t]{5}{*}{01096035} & 01096000 & 1.085 & 99 & 6.74 & 7.16 & 6.2 & 7.99 & 18.5 & \\
\hline & & & 98 & 8.19 & 8.58 & 4.8 & 10.1 & 23.8 & \\
\hline & & & 95 & 12.2 & 12.4 & 1.6 & 12.9 & 6.1 & \\
\hline & & & August & 22.5 & 21.7 & 3.6 & 20.1 & 10.7 & \\
\hline & & & Average & 12.4 & 12.5 & 4.0 & 12.8 & 14.8 & \\
\hline \multicolumn{10}{|c|}{ Wading River Basin (subbasin of Taunton River Basin) } \\
\hline \multirow[t]{5}{*}{01108490} & 01109000 & 0.359 & 99 & 1.13 & 0.75 & 33.3 & 0.26 & 76.6 & \multirow{5}{*}{$\begin{array}{l}\text { Drainage-area ratio computed as unregulated area for } \\
01108490\left(8.55 \mathrm{mi}^{2}\right) \text { divided by unregulated area for } \\
01109000\left(23.8 \mathrm{mi}^{2}\right) \text {. }\end{array}$} \\
\hline & & & 98 & 1.19 & .83 & 30.6 & .34 & 71.7 & \\
\hline & & & 95 & 1.41 & 1.15 & 18.4 & .59 & 58.0 & \\
\hline & & & August & 1.94 & 2.16 & 11.3 & 1.69 & 12.7 & \\
\hline & & & Average & 1.42 & 1.22 & 23.4 & .72 & 54.7 & \\
\hline \multirow[t]{5}{*}{01108600} & 01109000 & .161 & 99 & .36 & .34 & 6.37 & .15 & 58.4 & \\
\hline & . & & 98 & .38 & .37 & 2.12 & .19 & 48.7 & \\
\hline & & . & 95 & .44 & .52 & 15.7 & .32 & 27.6 & \\
\hline & & & August & .61 & .97 & 58.6 & .76 & 24.1 & \\
\hline & & & Average & .45 & .55 & 20.7 & .36 & 39.7 & · \\
\hline
\end{tabular}


Table 7. Low-flow statistics estimated using available data, the drainage-area ratio method, and regression equations; and absolute percent differences between the data-based estimates and estimates from the drainage-area ratio method and regression equations for stations used to analyze to applicability of the drainagearea ratio method for estimating low-flow statistics for ungaged Massachusetts streams--Continued

\begin{tabular}{|c|c|c|c|c|c|c|c|c|c|}
\hline \multirow{2}{*}{$\begin{array}{l}\text { Station } \\
\text { No. }\end{array}$} & \multirow{2}{*}{$\begin{array}{l}\text { Index } \\
\text { stream- } \\
\text { gaging } \\
\text { station } \\
\text { No. }\end{array}$} & \multirow{2}{*}{$\begin{array}{l}\text { Drainage- } \\
\text { area } \\
\text { ratio }\end{array}$} & \multirow{2}{*}{$\begin{array}{l}\text { Low-flow } \\
\text { statistic }\end{array}$} & \multirow{2}{*}{$\begin{array}{l}\text { Data-based } \\
\text { estimate } \\
\left(\mathrm{ft}^{3} / \mathrm{s}\right)\end{array}$} & \multicolumn{2}{|c|}{$\begin{array}{l}\text { Drainage-area ratio } \\
\text { method }\end{array}$} & \multicolumn{2}{|c|}{ Regression equations } & \multirow[b]{2}{*}{ Remarks } \\
\hline & & & & & $\begin{array}{l}\text { Estimate } \\
\left(\mathrm{ft}^{3} / \mathrm{s}\right)\end{array}$ & $\begin{array}{c}\text { Absolute } \\
\text { percent } \\
\text { difference }\end{array}$ & $\begin{array}{c}\text { Estimate } \\
\left(\mathrm{tt}^{3} / \mathrm{s}\right)\end{array}$ & $\begin{array}{l}\text { Absolute } \\
\text { percent } \\
\text { difference }\end{array}$ & \\
\hline \multicolumn{10}{|c|}{ Wading River Basin (subbasin of Taunton River Basin)_Continued } \\
\hline \multirow[t]{5}{*}{01108700} & \multirow[t]{10}{*}{01109000} & \multirow[t]{5}{*}{0.403} & 99 & 1.10 & 0.85 & 23.0 & 0.38 & 65.6 & \multirow{5}{*}{$\begin{array}{l}\text { Drainage-area ratio computed as unregulated area for } \\
01108700\left(9.60 \mathrm{mi}^{2}\right) \text { divided by unregulated area for } \\
01109000\left(23.8 \mathrm{mi}^{2}\right) \text {. }\end{array}$} \\
\hline & & & 98 & 1.17 & .93 & 20.7 & .48 & 59.3 & \\
\hline & & & 95 & 1.47 & 1.29 & 12.2 & .79 & 46.1 & \\
\hline & & & August & 2.25 & 2.42 & 7.6 & 2.1 & 10.5 & \\
\hline & & & Average & 1.50 & 1.37 & 15.9 & .91 & 45.4 & \\
\hline \multirow[t]{5}{*}{01109000} & & 1.000 & 99 & 2.10 & - & - & 1.10 & 47.7 & \multirow{5}{*}{$\begin{array}{l}\text { Statistics computed for the period corresponding to the } \\
\text { period of record for station } 01108500,1954-86 \text {. }\end{array}$} \\
\hline & & & 98 & 2.30 & -- & - & 1.40 & 39.0 & \\
\hline & & & 95 & 3.20 & - & - & 2.26 & 29.4 & \\
\hline & & & August & 6.00 & -- & -- & 5.75 & 4.2 & \\
\hline & & & Average & 3.40 & -- & - & 2.63 & 30.1 & \\
\hline \multicolumn{10}{|c|}{ Green River Basin (subbasin of Deerfield River Basin) } \\
\hline \multirow[t]{5}{*}{01170020} & 01170100 & 0.125 & 99 & 0.52 & 0.80 & 53.9 & 0.26 & 49.3 & \\
\hline & & & 98 & .62 & .94 & 52.4 & .30 & 51.2 & \\
\hline & & & 95 & .77 & 1.15 & 50.1 & .45 & 41.3 & \\
\hline & & & August & 1.38 & 2.01 & 45.7 & 1.08 & 21.9 & \\
\hline & & & Average & .82 & 1.23 & 50.5 & .52 & 40.9 & \\
\hline \multirow[t]{5}{*}{01170025} & 01170100 & .408 & 99 & 2.90 & 2.61 & 10.0 & 1.40 & 51.9 & \\
\hline & & & 98 & 3.34 & 3.06 & 8.4 & 1.59 & 52.5 & \\
\hline & & & 95 & 4.02 & 3.75 & 6.7 & 2.12 & 47.2 & \\
\hline & & & August & 6.62 & 6.53 & 1.4 & 4.28 & 35.3 & \\
\hline & & & Average & 4.22 & 3.99 & 6.6 & 2.35 & 46.7 & \\
\hline
\end{tabular}


Table 7. Low-flow statistics estimated using available data, the drainage-area ratio method, and regression equations; and absolute percent differences between the data-based estimates and estimates from the drainage-area ratio method and regression equations for stations used to analyze to applicability of the drainagearea ratio method for estimating low-flow statistics for ungaged Massachusetts streams-Continued

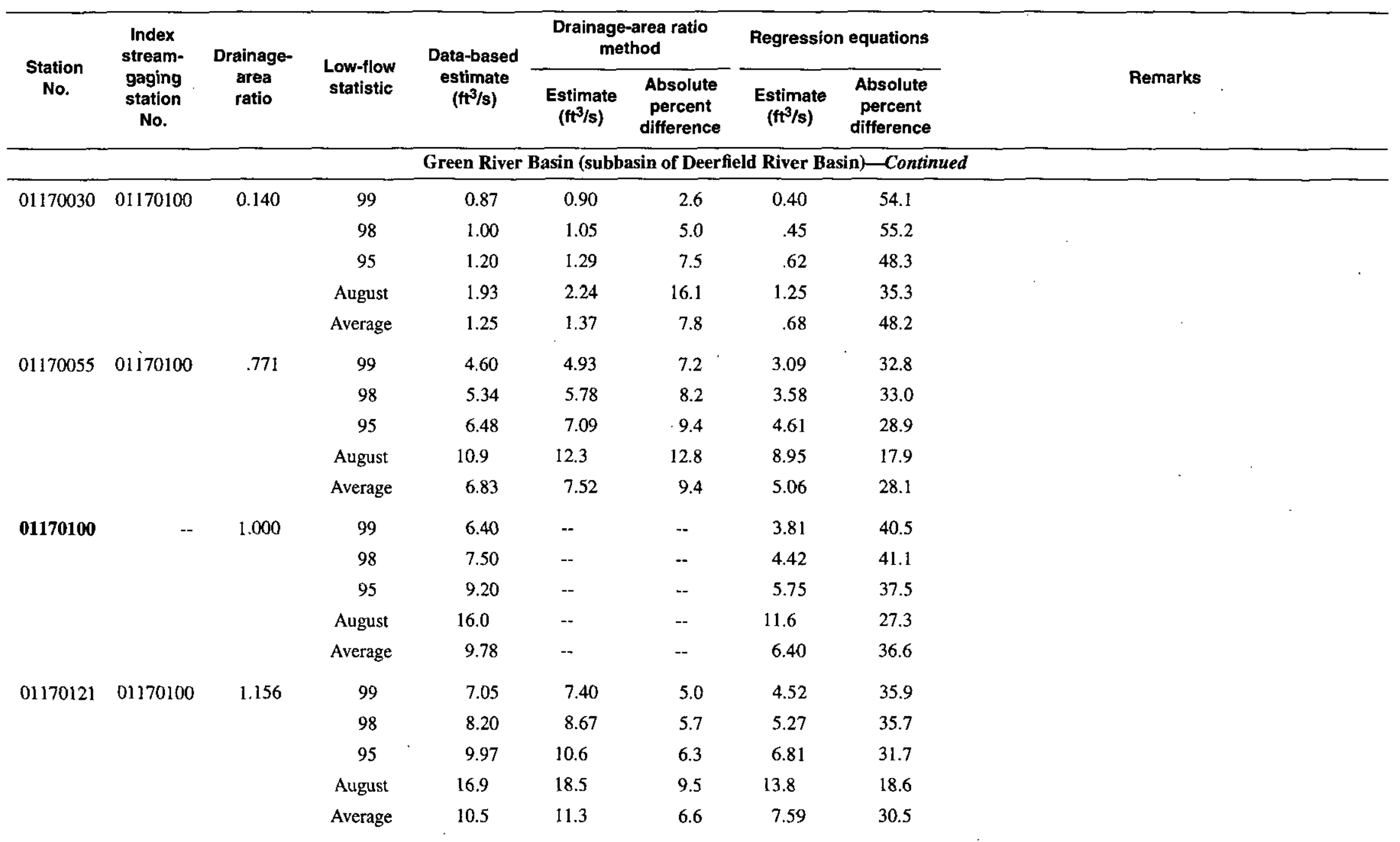


Table 7. Low-flow statistics estimated using available data, the drainage-area ratio method, and regression equations; and absolute percent differences between the data-based estimates and estimates from the drainage-area ratio method and regression equations for stations used to analyze to applicability of the drainagearea ratio method for estimating low-flow statistics for ungaged Massachusetts streams--Continued

\begin{tabular}{|c|c|c|c|c|c|c|c|c|c|}
\hline \multirow{2}{*}{$\begin{array}{l}\text { Station } \\
\text { No. }\end{array}$} & \multirow{2}{*}{$\begin{array}{c}\text { Index } \\
\text { stream- } \\
\text { gaging } \\
\text { station } \\
\text { No. }\end{array}$} & \multirow{2}{*}{$\begin{array}{l}\text { Drainage- } \\
\text { area } \\
\text { ratio }\end{array}$} & \multirow{2}{*}{$\begin{array}{l}\text { Low-flow } \\
\text { statistic }\end{array}$} & \multirow{2}{*}{$\begin{array}{c}\text { Data-based } \\
\text { estimate } \\
\left(\mathrm{ft}^{3} / \mathrm{s}\right)\end{array}$} & \multicolumn{2}{|c|}{$\begin{array}{c}\text { Drainage-area ratio } \\
\text { method }\end{array}$} & \multicolumn{2}{|c|}{ Regression equations } & \multirow[b]{2}{*}{ Remarks } \\
\hline & & & & & $\begin{array}{c}\text { Estimate } \\
\left(\mathrm{ft}^{3} / \mathrm{s}\right)\end{array}$ & $\begin{array}{c}\text { Absolute } \\
\text { percent } \\
\text { difference }\end{array}$ & $\begin{array}{c}\text { Estimate } \\
\left(\mathrm{ft}^{3} / \mathrm{s}\right)\end{array}$ & $\begin{array}{c}\text { Absolute } \\
\text { percent } \\
\text { difference }\end{array}$ & \\
\hline \multicolumn{10}{|c|}{ Green River Basin (subbasin of Deerfield River Basin)—Continued } \\
\hline \multirow[t]{5}{*}{01170141} & 01170100 & 1.256 & 99 & 7.32 & 8.04 & 9.8 & 5.20 & 29.0 & \\
\hline & & & 98 & 8.6 & 9.42 & 9.5 & 6.09 & 29.2 & \\
\hline & & & 95 & 10.6 & 11.6 & 9.4 & 7.76 & 26.7 & . \\
\hline & & & August & 18.6 & 20.1 & 8.1 & 15.3 & 17.6 & \\
\hline & & & Average & 1.3 & 12.3 & 9.2 & 8.59 & 25.6 & \\
\hline \multicolumn{10}{|c|}{ Quaboag River Basin (subbasin of Chicopee River Basin) } \\
\hline \multirow[t]{5}{*}{01175660} & 01175670 & 0.698 & 99 & 0.12 & 0.20 & 72.0 & 0.23 & 94.9 & \multirow{5}{*}{$\begin{array}{l}\text { Correlation estimates shown are the weighted averages of } \\
\text { those based on both gaging stations in the basin. }\end{array}$} \\
\hline & & & 98 & .16 & .25 & 55.9 & .27 & 65. & \\
\hline & & & 95 & .34 & .43 & 25.7 & .43 & 25.7 & \\
\hline & & & August & 1.46 & 1.26 & 13.7 & 1.22 & 16.4 & \\
\hline & & & Average & .52 & .54 & 41.8 & .54 & 50.6 & \\
\hline \multirow[t]{5}{*}{01175660} & 01176000 & .041 & 99 & .12 & .65 & 451 & .23 & 94.9 & \\
\hline & & & 98 & .16 & .81 & 405 & .27 & 65.2 & \\
\hline & & & 95 & .34 & 1.22 & 260 & .43 & 25.7 & \\
\hline & & & August & 1.46 & 2.60 & 78.1 & 1.22 & 16.4 & \\
\hline & & & Average & .52 & 1.32 & 298 & .54 & 50.6 & \\
\hline \multirow[t]{5}{*}{01175670} & 01176000 & .058 & 99 & .29 & .93 & 221 & .43 & 47.2 & \\
\hline & & & 98 & .36 & 1.16 & 222 & .50 & 37.8 & \\
\hline & & & 95 & .61 & 1.74 & 185 & .76 & 23.9 & \\
\hline & & & August & 1.80 & 3.72 & 107 & 2.01 & 11.7 & \\
\hline & & & Average & .76 & 1.89 & 184 & .92 & 30.2 & \\
\hline
\end{tabular}


Table 7. Low-flow statistics estimated using available data, the drainage-area ratio method, and regression equations; and absolute percent differences between the data-based estimates and estimates from the drainage-area ratio method and regression equations for stations used to analyze to applicability of the drainagearea ratio method for estimating low-flow statistics for ungaged Massachusetts streams-Continued

\begin{tabular}{|c|c|c|c|c|c|c|c|c|c|}
\hline \multirow{2}{*}{$\begin{array}{l}\text { Station } \\
\text { No. }\end{array}$} & \multirow{2}{*}{$\begin{array}{l}\text { Index } \\
\text { stream- } \\
\text { gaging } \\
\text { station } \\
\text { No. }\end{array}$} & \multirow{2}{*}{$\begin{array}{l}\text { Drainage- } \\
\text { area } \\
\text { ratio }\end{array}$} & \multirow{2}{*}{$\begin{array}{l}\text { Low-flow } \\
\text { statistic }\end{array}$} & \multirow{2}{*}{$\begin{array}{c}\text { Data-based } \\
\text { estimate } \\
\left(\mathrm{ft}^{3} / \mathrm{s}\right)\end{array}$} & \multicolumn{2}{|c|}{$\begin{array}{l}\text { Drainage-area ratio } \\
\text { method }\end{array}$} & \multicolumn{2}{|c|}{ Regression equations } & \multirow[b]{2}{*}{ Remarks } \\
\hline & & & & & $\begin{array}{l}\text { Estimate } \\
\left(t^{3} / s\right)\end{array}$ & $\begin{array}{l}\text { Absolute } \\
\text { percent } \\
\text { difference }\end{array}$ & $\begin{array}{c}\text { Estimate } \\
\left(\mathrm{ft}^{3} / \mathrm{s}\right)\end{array}$ & $\begin{array}{l}\text { Absolute } \\
\text { percent } \\
\text { difference }\end{array}$ & \\
\hline \multicolumn{10}{|c|}{ Quaboag River Basin (subbasin of Chicopee River Basin)-Continued } \\
\hline \multirow[t]{5}{*}{01175695} & 01175670 & 4.669 & 99 & 2.26 & 1.35 & 40.3 & 1.98 & 12.5 & \multirow{10}{*}{$\begin{array}{l}\text { Correlation estimates shown are the weighted averages of } \\
\text { those based on both gaging stations in the basin. }\end{array}$} \\
\hline & & & 98 & 2.88 & 1.68 & 41.7 & 2.32 & 19.4 & \\
\hline & & & 95 & 4.68 & 2.85 & 39.1 & 3.53 & 24.6 & \\
\hline & & & August & 11.9 & 8.40 & 29.4 & 10.5 & 11.8 & \\
\hline & & & Average & 5.43 & 3.57 & 37.6 & 4.58 & 17.1 & \\
\hline \multirow[t]{5}{*}{01175695} & 01176000 & .272 & 99 & 2.26 & 4.35 & 92.5 & 1.98 & 12.5 & \\
\hline & & & 98 & 2.88 & 5.43 & 88.5 & 2.32 & 19.4 & \\
\hline & & & 95 & 4.68 & 8.15 & 74.1 & 3.53 & 24.6 & \\
\hline & & & August & 11.9 & 17.4 & 46.2 & 10.5 & 11.8 & \\
\hline & & & Average & 5.43 & 8.83 & 75.3 & 4.58 & 17.1 & \\
\hline \multirow[t]{5}{*}{01175905} & 0175670 & 15.92 & 99 & 18.1 & 4.62 & 74.5 & 7.01 & 61.3 & \multirow{5}{*}{$\begin{array}{l}\text { Correlation estimates shown are the weighted averages of } \\
\text { those based on both gaging stations in the basin. }\end{array}$} \\
\hline & & & 98 & 21.5 & 5.73 & 73.3 & 8.69 & 59.6 & \\
\hline & & & 95 & 30.6 & 9.71 & 68.3 & 13.2 & 56.9 & \\
\hline & & & August & 62.5 & 28.6 & 54.2 & 43.6 & 30.2 & \\
\hline & & & Average & 33.2 & 12.2 & 67.6 & 18.1 & 52.0 & \\
\hline \multirow[t]{5}{*}{01175905} & 01176000 & .926 & 99 & 18.1 & 14.8 & 18.2 & 7.01 & 61.3 & \\
\hline & & & 98 & 21.5 & 18.5 & 14.0 & 8.69 & 59.6 & \\
\hline & & & 95 & 30.6 & 27.8 & 9.2 & 13.2 & 56.9 & \\
\hline & & & August & 62.5 & 59.3 & 5.1 & 43.6 & 30.2 & \\
\hline & & & Average & 33.2 & 30.1 & 11.6 & 18.1 & 52.0 & \\
\hline
\end{tabular}


Table 7. Low-flow statistics estimated using available data; the drainage-area ratio method, and regression equations; and absolute percent differences.between the data-based estimates and estimates from the drainage-area ratio method and regression equations for stations used to analyze to applicability of the drainagearea ratio method for estimating low-flow statistics for ungaged Massachusetts streams-Continued

\begin{tabular}{|c|c|c|c|c|c|c|c|c|c|}
\hline \multirow{2}{*}{$\begin{array}{l}\text { Station } \\
\text { No. }\end{array}$} & \multirow{2}{*}{$\begin{array}{l}\text { Index } \\
\text { stream- } \\
\text { gaging } \\
\text { station } \\
\text { No. }\end{array}$} & \multirow{2}{*}{$\begin{array}{l}\text { Drainage- } \\
\text { area } \\
\text { ratio }\end{array}$} & \multirow{2}{*}{$\begin{array}{l}\text { Low-flow } \\
\text { statistic }\end{array}$} & \multirow{2}{*}{$\begin{array}{l}\text { Data-based } \\
\text { estimate } \\
\left(\mathrm{ft}^{3} / \mathrm{s}\right)\end{array}$} & \multicolumn{2}{|c|}{$\begin{array}{c}\text { Drainage-area ratio } \\
\text { method }\end{array}$} & \multicolumn{2}{|c|}{ Regression equations } & \multirow[b]{2}{*}{ Remarks } \\
\hline & & & & & $\begin{array}{c}\text { Estimate } \\
\left(\mathrm{ft}^{3} / \mathrm{s}\right)\end{array}$ & $\begin{array}{l}\text { Absolute } \\
\text { percent } \\
\text { difference }\end{array}$ & $\begin{array}{c}\text { Estimate } \\
\left(\mathrm{ft}^{3} / \mathrm{s}\right)\end{array}$ & $\begin{array}{c}\text { Absolute } \\
\text { percent } \\
\text { difference }\end{array}$ & \\
\hline \multirow[t]{5}{*}{01176000} & \multirow[t]{5}{*}{01175670} & \multirow[t]{5}{*}{17.19} & 99 & 16.0 & 4.98 & 68.9 & 13.5 & 15.6 & \multirow{5}{*}{$\begin{array}{l}\text { Statistics computed for the period corresponding to the } \\
\text { period of record available at the time of analysis for } \\
\text { station } 01175670,1961-1996 .\end{array}$} \\
\hline & & & 98 & 20.0 & 6.19 & 69.1 & 17.0 & 14.7 & \\
\hline & & & 95 & 30.0 & 10.5 & 65.0 & 22.7 & 24.4 & \\
\hline & & & August & 64.0 & 30.9 & 51.7 & 55.4 & 13.4 & \\
\hline & & & Average & 32.5 & 13.1 & 63.7 & 27.2 & 17.0 & \\
\hline \multicolumn{10}{|c|}{ Quaboag River Basin (subbasin of Chicopee River Basin)—Continued } \\
\hline \multirow[t]{5}{*}{01176350} & \multirow[t]{5}{*}{01175670} & \multirow[t]{5}{*}{20.72} & 99 & 27.3 & 6.01 & 78.0 & 17.0 & 37.8 & \multirow{5}{*}{$\begin{array}{l}\text { Correlation estimates shown are the weighted averages of } \\
\text { those based on both gaging stations in the basin. } \\
\text { Some basin characteristics for this station are larger than } \\
\text { those for any station used in the regression analyses to } \\
\text { determine the equations. }\end{array}$} \\
\hline & & & 98 & 32.1 & 7.46 & 76.8 & 21.7 & 32.4 & \\
\hline & & & 95 & 44.3 & 12.6 & 71.6 & 28.6 & 35.3 & \\
\hline & & & August & 84.7 & 37.3 & 56.0 & 70.0 & 17.4 & \\
\hline & & & Average & 47.1 & 15.8 & 70.6 & 34.3 & 30.7 & \\
\hline \multirow[t]{5}{*}{01176350} & \multirow[t]{5}{*}{01176000} & \multirow[t]{5}{*}{1.206} & 99 & 27.3 & 19.3 & 29.3 & 17.0 & 37.8 & \\
\hline & & & 98 & 32.1 & 24.1 & 24.9 & 21.7 & 32.4 & \\
\hline & & & 95 & 44.3 & 36.2 & 18.3 & 28.6 & 35.3 & \\
\hline & & & August & 84.7 & 77.2 & 8.9 & 70.0 & 17.4 & \\
\hline & & & Average & 47.1 & 39.2 & 20.3 & 34.3 & 30.7 & \\
\hline \multirow[t]{5}{*}{01176435} & \multirow[t]{5}{*}{01175670} & \multirow[t]{5}{*}{24.41} & 99 & 33.4 & 7.08 & 78.8 & 23.0 & 31.0 & \multirow{10}{*}{$\begin{array}{l}\text { Correlation estimates shown are the weighted averages of } \\
\text { those based on both gaging stations in the basin. } \\
\text { Some basin characteristics for this station are larger than } \\
\text { those for any station used in the regression analyses to } \\
\text { determine the equations. }\end{array}$} \\
\hline & & & 98 & 39.2 & 8.79 & 77.6 & 29.8 & 23.9 & \\
\hline & & & 95 & 54.6 & 14.9 & 72.7 & 38.2 & 30.1 & \\
\hline & & & August & 105 & 43.9 & 58.2 & 88.3 & 15.9 & \\
\hline & & & Average & 58.0 & 18.7 & 71.8 & 44.8 & 25.2 & \\
\hline \multirow[t]{5}{*}{01176435} & \multirow[t]{5}{*}{01176000} & \multirow[t]{5}{*}{1.42} & 99 & 33.4 & 22.7 & 32.0 & 23.0 & 31.0 & \\
\hline & & & 98 & 39.2 & 28.4 & 27.6 & 29.8 & 23.9 & \\
\hline & & & 95 & ' 54.6 & 42.6 & 22.0 & 38.2 & 30.1 & \\
\hline & & & August & 105 & 90.9 & 13.4 & 88.3 & 15.9 & \\
\hline & & & Average & 58.0 & 46.2 & 23.7 & 44.8 & 25.2 & \\
\hline
\end{tabular}


Table 7. Low-flow statistics estimated using available data, the drainage-area ratio method, and regression equations; and absolute percent differences between the data-based estimates and estimates from the drainage-area ratio method and regression equations for stations used to analyze to applicability of the drainagearea ratio method for estimating low-flow statistics for ungaged Massachusetts streams--Continued

\begin{tabular}{|c|c|c|c|c|c|c|c|c|c|}
\hline \multirow{2}{*}{$\begin{array}{l}\text { Station } \\
\text { No. }\end{array}$} & \multirow{2}{*}{$\begin{array}{l}\text { Index } \\
\text { stream- } \\
\text { gaging } \\
\text { station } \\
\text { No. }\end{array}$} & \multirow{2}{*}{$\begin{array}{l}\text { Drainage- } \\
\text { area } \\
\text { ratio }\end{array}$} & \multirow{2}{*}{$\begin{array}{l}\text { Low-flow } \\
\text { statistic }\end{array}$} & \multirow{2}{*}{$\begin{array}{l}\text { Data-based } \\
\text { estimate } \\
\left(\mathrm{tt}^{3} / \mathrm{s}\right)\end{array}$} & \multicolumn{2}{|c|}{$\begin{array}{l}\text { Drainage-area ratio } \\
\text { method }\end{array}$} & \multicolumn{2}{|c|}{ Regression equations } & \multirow[b]{2}{*}{ Remarks } \\
\hline & & & & & $\begin{array}{l}\text { Estimate } \\
\left(\mathrm{ft}^{3} / \mathrm{s}\right)\end{array}$ & $\begin{array}{c}\text { Absolute } \\
\text { percent } \\
\text { difference }\end{array}$ & $\begin{array}{l}\text { Estimate } \\
\left(\mathrm{ft}^{3} / \mathrm{s}\right)\end{array}$ & $\begin{array}{c}\text { Absolute } \\
\text { percent } \\
\text { difference }\end{array}$ & \\
\hline \multicolumn{10}{|c|}{ West Branch Westfield River Basin (subbasin of Westfield River Basin) } \\
\hline \multirow[t]{5}{*}{01180600} & 01180800 & 4.325 & 99 & 0.51 & 1.12 & 120 & 0.627 & 23.2 & \multirow{10}{*}{$\begin{array}{l}\text { Correlation estimates shown are the weighted averages of } \\
\text { those based on both gaging stations in the basin. }\end{array}$} \\
\hline & & & 98 & .68 & 1.30 & 90.9 & .70 & 2.9 & \\
\hline & & & 95 & 1.03 & 1.73 & 68.0 & 1.05 & 1.9 & \\
\hline & & & August & 2.45 & 3.46 & 41.2 & 2.69 & 10.0 & \\
\hline & & & Average & 1.17 & 1.90 & 80.0 & 1.27 & 9.5 & \\
\hline \multirow[t]{5}{*}{01180600} & 01181000 & .136 & 99 & .51 & .98 & 91.9 & .627 & 23.2 & \\
\hline & & . & 98 & .68 & 1.21 & 77.7 & .70 & 2.9 & \\
\hline & & & 95 & 1.03 & 1.63 & 58.3 & 1.05 & 1.9 & \\
\hline & & & August & 2.45 & 2.99 & 22.0 & 2.69 & 10.0 & \\
\hline & & & Average & 1.17 & 1.70 & 62.5 & 1.27 & 9.5 & \\
\hline \multirow[t]{5}{*}{01180750} & 01180800 & 18.22 & 99 & 2.87 & 4.74 & 65.2 & 5.02 & 75.1 & \multirow{10}{*}{$\begin{array}{l}\text { Correlation estimates shown are the weighted averages of } \\
\text { those based on both gaging stations in the basin. }\end{array}$} \\
\hline & & & 98 & 3.67 & 5.47 & 49.0 & 5.86 & 59.5 & \\
\hline & & & 95 & 5.23 & 7.29 & 39.4 & 7.57 & 44.8 & \\
\hline & & & August & 10.9 & 14.6 & 33.9 & 15.4 & 41.5 & \\
\hline & & & Average & 5.67 & 8.02 & 46.9 & 8.47 & 55.2 & \\
\hline \multirow[t]{5}{*}{01180750} & 01181000 & .572 & 99 & 2.87 & 4.12 & 43.6 & .5 .02 & 75.1 & \\
\hline & & & 98 & 3.67 & 5.09 & 38.7 & 5.86 & 59.5 & \\
\hline & & & 95 & 5.23 & 6.86 & 31.2 & 7.57 & 44.8 & \\
\hline & & & August & 10.9 & 12.6 & 15.6 & 15.4 & 41.5 & \\
\hline & & & Average & 5.67 & 7.17 & 32.3 & 8.47 & 55.2 & \\
\hline
\end{tabular}


Table 7. Low-flow statistics estimated using available data, the drainage-area ratio method, and regression equations; and absolute percent differences between the data-based estimates and estimates from the drainage-area ratio method and regression equations for stations used to analyze to applicability of the drainagearea ratio method for estimating low-flow statistics for ungaged Massachusetts streams-Continued

\begin{tabular}{|c|c|c|c|c|c|c|c|c|c|}
\hline \multirow[b]{2}{*}{$\begin{array}{l}\text { Station } \\
\text { No. }\end{array}$} & \multirow{2}{*}{$\begin{array}{l}\text { Index } \\
\text { stream- } \\
\text { gaging } \\
\text { station } \\
\text { No. }\end{array}$} & \multirow{2}{*}{$\begin{array}{l}\text { Drainage- } \\
\text { area } \\
\text { ratio }\end{array}$} & \multirow{2}{*}{$\begin{array}{l}\text { Low-flow } \\
\text { statistic }\end{array}$} & \multirow{2}{*}{$\begin{array}{c}\text { Data-based } \\
\text { estimate } \\
\left(\mathrm{ft}^{3} / \mathrm{s}\right)\end{array}$} & \multicolumn{2}{|c|}{$\begin{array}{l}\text { Drainage-area ratio } \\
\text { method }\end{array}$} & \multicolumn{2}{|c|}{ Regression equations } & \multirow[b]{2}{*}{ Remarks } \\
\hline & & & & & $\begin{array}{l}\text { Estimate } \\
\left(\mathrm{ft}^{3} / 8\right)\end{array}$ & $\begin{array}{l}\text { Absolute } \\
\text { percent } \\
\text { difference }\end{array}$ & $\begin{array}{l}\text { Estimate } \\
\left(\mathrm{ft}^{3} / \mathrm{s}\right)\end{array}$ & $\begin{array}{l}\text { Absolute } \\
\text { percent } \\
\text { difference }\end{array}$ & \\
\hline \multicolumn{10}{|c|}{ West Branch Westfield River Basin (subbasin of Westfield River Basin)_C Continued } \\
\hline \multirow[t]{5}{*}{01180780} & 01180800 & 0.390 & 99 & 0.12 & 0.10 & 18.5 & 0.009 & 92.7 & \multirow{5}{*}{$\begin{array}{l}\text { Correlation estimates shown are the weighted averages of } \\
\text { those based on both gaging stations in the basin. }\end{array}$} \\
\hline & & & 98 & .14 & .12 & 19.3 & .022 & 84.8 & \\
\hline & & & 95 & .18 & .16 & 13.8 & .041 & 77.3 & \\
\hline & & & August & .29 & .31 & 9.1 & .14 & 49.3 & \\
\hline & & & Average & .18 & .17 & 15.2 & .054 & 76.1 & \\
\hline \multirow[t]{5}{*}{01180780} & 01181000 & .012 & 99 & .12 & .088 & 29.0 & .009 & 92.7 & \\
\hline & & & 98 & .14 & .11 & 24.8 & .022 & 84.8 & \\
\hline & & & 95 & .18 & .15 & 18.8 & .041 & 77.3 & \\
\hline & . & & August & .29 & .27 & 5.9 & .14 & 49.3 & \\
\hline & & & Average & .18 & .15 & 19.6 & .054 & 76.1 & \\
\hline \multirow[t]{5}{*}{01180800} & 01181000 & .031 & 99 & .26 & .23 & 13.1 & .095 & 63.5 & \\
\hline & & & 98 & .30 & .28 & 7.0 & .11 & 62.7 & \\
\hline & & & 95 & .40 & .38 & 6.0 & .18 & 54.3 & \\
\hline & & & August & .80 & .69 & 13.8 & .51 & 36.6 & \\
\hline & & & Average & .44 & .39 & 10.0 & .22 & 54.3 & \\
\hline \multirow[t]{5}{*}{01180821} & 01180800 & 24.57 & 99 & 2.34 & 6.39 & 173 & 7.1 & 204 & \multirow{5}{*}{$\begin{array}{l}\text { Correlation estimates shown are the weighted averages of } \\
\text { those based on both gaging stations in the basin. }\end{array}$} \\
\hline & & 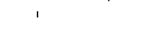 & 98 & 2.77 & 7.37 & 166 & 8.40 & 203 & \\
\hline & & & 95 & 3.53 & 9.83 & 178 & 10.8 & 205 & \\
\hline & . & & August & 5.84 & 19.6 & 236 & 22.1 & 278 & \\
\hline & & & Average & 3.62 & 1.8 & 188 & 12.1 & 223 & \\
\hline
\end{tabular}


Table 7. Low-flow statistics estimated using available data, the drainage-area ratio method, and regression equations; and absolute percent differences between the data-based estimates and estimates from the drainage-area ratio method and regression equations for stations used to analyze to applicability of the drainagearea ratio method for estimating low-flow statistics for ungaged Massachusetts streams-Continued

\begin{tabular}{|c|c|c|c|c|c|c|c|c|c|}
\hline \multirow[b]{2}{*}{$\begin{array}{l}\text { Station } \\
\text { No. }\end{array}$} & \multirow{2}{*}{$\begin{array}{c}\text { Index } \\
\text { stream- } \\
\text { gaging } \\
\text { station } \\
\text { No. }\end{array}$} & \multirow{2}{*}{$\begin{array}{l}\text { Drainage- } \\
\text { area } \\
\text { ratio }\end{array}$} & \multirow[b]{2}{*}{$\begin{array}{l}\text { Low-flow } \\
\text { statistic }\end{array}$} & \multirow{2}{*}{$\begin{array}{c}\text { Data-based } \\
\text { estimate } \\
\left(\mathrm{ft}^{3} / \mathrm{s}\right)\end{array}$} & \multicolumn{2}{|c|}{$\begin{array}{l}\text { Drainage-area ratio } \\
\text { method }\end{array}$} & \multicolumn{2}{|c|}{ Regression equations } & \multirow[b]{2}{*}{ Remarks } \\
\hline & & & & & $\begin{array}{l}\text { Estimate } \\
\left(\mathrm{tt}^{3} / \mathrm{s}\right)\end{array}$ & $\begin{array}{c}\text { Absolute } \\
\text { percent } \\
\text { difference }\end{array}$ & $\begin{array}{l}\text { Estimate } \\
\left(\mathrm{ft}^{3} / \mathrm{s}\right)\end{array}$ & $\begin{array}{c}\text { Absolute } \\
\text { percent } \\
\text { difference }\end{array}$ & \\
\hline \multicolumn{10}{|c|}{ West Branch Westfield River Basin (subbasin of Westfield River Basin)—Continued } \\
\hline \multirow[t]{5}{*}{01180821} & 01181000 & 0.771 & 99 & 2.34 & 5.55 & 137 & 7.1 & 204 & \\
\hline & & & 98 & 2.77 & 6.86 & 148 & 8.40 & 203 & \\
\hline & & & 95 & 3.53 & 9.25 & 162 & 10.8 & 205 & \\
\hline & & & August & 5.84 & 17.0 & 191 & 22.1 & 278 & \\
\hline & & & Average & 3.62 & 9.66 & 160 & 12.1 & 223 & \\
\hline \multirow[t]{5}{*}{01181000} & 01180800 & 31.86 & 99 & 7.2 & 8.28 & 15.0 & 10.3 & 43.3 & \multirow{5}{*}{$\begin{array}{l}\text { Statistics computed for the period corresponding to the } \\
\text { period of record for station } 01180800,1963-77\end{array}$} \\
\hline & & & 98 & 8.9 & 9.56 & 7.4 & 12.4 & 38.8 & \\
\hline & & & 95 & 12.0 & 12.7 & 5.8 & 15.4 & 28.6 & \\
\hline & & & August & 22.0 & 25.5 & 15.9 & 30.4 & 38.3 & \\
\hline & & & Average & 12.5 & 14.0 & 11.0 & 17.1 & 37.2 & \\
\hline
\end{tabular}


Table 8. Descriptions of low-flow partial-record stations used in the regression analyses

[Basin number: Number refers to figure 1. No., number]

\begin{tabular}{|c|c|c|c|c|c|c|}
\hline $\begin{array}{l}\text { Station } \\
\text { No. }\end{array}$ & $\begin{array}{l}\text { Latitude } \\
0, \prime \prime\end{array}$ & $\begin{array}{l}\text { Longitude } \\
0, " 1\end{array}$ & $\begin{array}{l}\text { Basin } \\
\text { No. }\end{array}$ & Station name & $\begin{array}{l}\text { Number } \\
\text { of meas- } \\
\text { urements }\end{array}$ & $\begin{array}{l}\text { Gaging stations used for } \\
\text { correlation }\end{array}$ \\
\hline 01073860 & 425100 & 705159 & 18 & Smallpox Brook at Salisbury, Mass. & 10 & $01101000,01097300,01096000,01073000$ \\
\hline 01094340 & 423335 & 715202 & 11 & Whitman River near Westminster, Mass. & 13 & $\begin{array}{l}01109000,01097300,01105600,01105730,01111300 \\
\quad 01111200\end{array}$ \\
\hline 01094396 & 423428 & 715015 & 11 & Philips Brook at Fitchburg, Mass. & 10 & $01096000,01097300,01162500,01175670,01101000$ \\
\hline 01094760 & 422349 & 714648 & 11 & Waushacum Brook near West Boylston, Mass. & 10 & $01097300,01096000,01111300,01175670$ \\
\hline 01095220 & 422439 & 714730 & 11 & Stillwater River near Sterling, Mass. & 23 & $01096000,01097300,01175670,01162500,01111200$ \\
\hline 01095380 & 422300 & 715012 & 11 & Trout Brook near Holden, Mass. & 19 & $01175670,01097300,01096000,01162500,01111200$ \\
\hline 01095915 & 423426 & 713743 & 11 & Mulpus Brook near Shirley, Mass. & 11 & $01097300,01096000,01162500,01175670$ \\
\hline 01095928 & 424024 & 714639 & 11 & Trapfall Brook near Ashby, Mass. & 18 & $01162500,01175670,01096000,01097300$ \\
\hline 01096504 & 424003 & 713355 & 11 & Reedy Meadow Brook at East Pepperell, Mass. & 17 & $01096000,01097300,01162500,01101000$ \\
\hline 01096505 & 424123 & 713254 & 11 & Unkety Brook near Pepperell, Mass. & 22 & $01096000,01097300,01162500,01101000$ \\
\hline 01096515 & 424041 & 712938 & 13 & Salmon Brook at Main Street at Dunstable, Mass. & 17 & $01162500,01101000,01096000,01073000,01097300$ \\
\hline 01096805 & 422115 & 713740 & 14 & North Brook near Berlin, Mass. & 16 & $01175670,01097300,01162500,01096000$ \\
\hline 01096855 & 422357 & 713400 & 14 & Danforth Brook at Hudson, Mass. & 16 & $\begin{array}{l}0107300,01096000,01175670,01105600,01111300 \\
\quad 01111200\end{array}$ \\
\hline 01096935 & 422547 & 713056 & 14 & Elizabeth Brook at Wheeler Street at Stow, Mass. & 12 & $01097300,01096000,01175670,01111200,01111300$ \\
\hline 01097280 & 422807 & 712431 & 14 & Fort Pond Brook at West Concord, Mass. & 16 & $01097300,01105600,01109000,01111300,01111200$ \\
\hline 01099400 & 423729 & 711911 & 14 & River Meadow Brook at Lowell, Mass. & 13 & $01097300,01096000,01101000,01105600$ \\
\hline 01100608 & 423714 & 711244 & 15 & Meadow Brook near Tewksbury, Mass. & 15 & $01073000,01096000,01097300,01105600,01101000$ \\
\hline 01101100 & 424331 & 705454 & 16 & Mill River near Rowley, Mass. & 9 & $01101000,01097300,01073000$ \\
\hline 01102053 & 423334 & 705655 & 18 & Crane Brook at Danvers, Mass. & 10 & $01073000,01096000,01097300,01105600,01101000$ \\
\hline 01102490 & 422816 & 711034 & 18 & Shaker Glen Brook near Woburn, Mass. & 13 & $01097300,01105600,01101000$ \\
\hline 01103015 & 422520 & 710859 & 20 & Mill Brook at Arlington, Mass. & 20 & $01097300,01105600,01101000$ \\
\hline 01103253 & 420827 & 712526 & 20 & Chicken Brook near West Medway, Mass. & 22 & $01109000,01073000,01111300,01111200$ \\
\hline 01103435 & 421713 & 711805 & 20 & Waban Brook at Wellesley, Mass. & 11 & $01109000,01097300,01111300,01111200,01175670$ \\
\hline 01103440 & 421745 & 711718 & 20 & Fuller Brook at Wellesley, Mass. & 18 & $01097300,01111300,01111200,01109000$ \\
\hline 01104960 & 421104 & 711329 & 19 & Germany Brook near Norwood, Mass. & 18 & $01111200,01111300,01109000,01105730,01101000$ \\
\hline 01104980 & 421026 & 711231 & 19 & Hawes Brook at Norwood, Mass. & 20 & $\begin{array}{l}01109000,01097300,01105600,01105730,01111300 \\
01111200\end{array}$ \\
\hline 01105100 & 420936 & 711147 & 19 & Traphole Brook near Norwood, Mass. & 26 & $01101000,01111300,01105730,01105870,01109000$ \\
\hline 01105270 & 420859 & 710858 & 19 & Massapoag Brook at Canton, Mass. & 9 & $\begin{array}{l}01109000,01097300,01105600,01105730,01111300 \text {, } \\
01111200\end{array}$ \\
\hline 01105568 & 420919 & 710137 & 19 & Cochato River at Holbrook, Mass. & 9 & $01105600,01097300,01105730,01109000$ \\
\hline 01105575 & 421102 & 710042 & 19 & Cranberry Brook at Braintree Highlands, Mass. & 16 & $01105600,01097300,01105730,01109000$ \\
\hline
\end{tabular}


Table 8. Descriptions of low-flow partial-record stations used in the regression analyses-Continued

\begin{tabular}{|c|c|c|c|c|}
\hline $\begin{array}{c}\text { Station } \\
\text { No. }\end{array}$ & 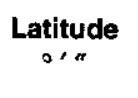 & Longitude & $\begin{array}{c}\text { Basin } \\
\text { No. }\end{array}$ & Station name \\
\hline 01105582 & 421325 & 705949 & 19 & Monatiquot River at Braintree, Mass. \\
\hline 01105630 & 421253 & 705306 & 19 & Crooked Meadow River near Hingham Center, Mass. \\
\hline 01105670 & 421135 & 704344 & 21 & Satuit River at Scituate, Mass. \\
\hline 01105820 & 420936 & 704720 & 21 & Second Herring Brook at Norwell, Mass. \\
\hline 01105830 & 421130 & 704649 & 21 & First Herring Brook near Scituate Center, Mass. \\
\hline 01105861 & 415947 & 704718 & 21 & Jones River Brook near Kingston, Mass. \\
\hline 011058839 & 414621 & 703346 & 21 & Herring River at Bournedale, Mass. \\
\hline 011059106 & 414435 & 705204 & 13 & Mattapoisett River tributary \#1 near Rochester, Mass. \\
\hline 01105930 & 414043 & 705839 & 24 & $\begin{array}{l}\text { Paskamanset River at Tumer Pond near New Bedford, } \\
\text { Mass. }\end{array}$ \\
\hline 01105935 & 413420 & 710047 & 24 & Destruction Brook near South Dartmouth, Mass. \\
\hline 01105937 & 414055 & 710105 & 24 & Shingle Island River near North Dartmouth, Mass. \\
\hline 01105947 & 413800 & 710346 & 24 & Bread and Cheese Brook at Head of Westport, Mass. \\
\hline 01106460 & 420243 & 705817 & 25 & Beaver Brook near East Bridgewater, Mass. \\
\hline 01107400 & 415155 & 705432 & 25 & Fall Brook near Middleboro, Mass. \\
\hline 01108140 & 415420 & 705919 & 25 & Poquoy Brook near North Middleboro, Mass. \\
\hline 01108180 & 415257 & 710254 & 25 & Cotley River at East Taunton, Mass. \\
\hline 01108600 & 415911 & 711427 & 25 & Hodges Brook at West Mansfield, Mass. \\
\hline 01109087 & 414757 & 710337 & 25 & Assonet River at Assonet, Mass. \\
\hline 01109090 & 414636 & 710523 & 25 & Rattlesnake Brook near Assonet, Mass. \\
\hline 01109225 & 414652 & 711503 & 26 & Rocky Run near Rehoboth, Mass. \\
\hline 01109460 & 421220 & 715006 & 12 & Dark Brook at Auburn, Mass. \\
\hline 01111142 & 421125 & 713923 & 12 & Miscoe Brook near Grafton, Mass. \\
\hline 01111225 & 420240 & 713721 & 12 & Emerson Brook near Uxbridge, Mass. \\
\hline 01112190 & 420535 & 713111 & 12 & Muddy Brook at South Milford, Mass. \\
\hline 01123140 & 420635 & 721151 & 10 & Mill Brook at Brimfield, Mass. \\
\hline
\end{tabular}

Number
Gaging stations used for
correlation

$10 \quad 01105600,01097300,01105730,01109000$

$1501109000,01097300,01105600,01105730,01111300$, 01111200

$901105600,01105730,01105870$

$15 \quad 01105600,01105730,01105870,01109000$

$1601105600,01111200,01111300,01109000,01105730$

$1401105600,01109000,01105870,01097300$

$1201109000,01158837,01105870,01105730$

$1301109000,01105870,01111200,01105730$

$2301109000,01105600,01105730,01111200,01106000$

$2401109000,01105600,01105870,01105730,01111200$

$2501109000,01105600,01105730,01111200,01106000$

$2401109000,01105600,01105870,01105730,01111200$, 01106000

$2101109000,01118000.01105730,01105870,01111200$, 01111300

$36 \quad 01105600,01111300,01105730,01109000$

$1601109000,01105600,01111300,01105730$

$1401109000,01105600,01111300,01105730$

$2701109000,01105730,01105870,01111200,01111300$

$2201109000,01105730,01097300,01111200,01111300$

$1101109000,01111200,01105730,01118000,01105870$, 01106000

$3601109000,01118000,01111200,01111300,01106000$

$1801097300,01105600,01109000,01111200,01111300$, 01175670

$1101097300,01105600,01109000,01175670$

$1201097300,01109000,01111300,01175670$

$1301097300,01109000,01111300,01175670$

$901111300,01121000,01174900,01175670,01176000$, 01184490 
Table 8. Descriptions of low-flow partial-record stations used in the regression analyses-Continued

\begin{tabular}{|c|c|c|c|c|c|c|}
\hline $\begin{array}{l}\text { Station } \\
\text { No. }\end{array}$ & $\begin{array}{l}\text { Latitude } \\
\text { o," }\end{array}$ & Longitude & $\begin{array}{l}\text { Basin } \\
\text { No. }\end{array}$ & Station name & $\begin{array}{l}\text { Number } \\
\text { of meas- } \\
\text { urements }\end{array}$ & $\begin{array}{l}\text { Gaging stations used for } \\
\text { correlation }\end{array}$ \\
\hline 01123161 & 420625 & 721136 & 10 & Wales Brook at Brimfield, Mass. & 10 & $01121000,01174000,01175670$ \\
\hline 01123200 & 420341 & 720945 & 10 & Stevens Brook at Holland, Mass. & 22 & $01176000,01175670,01171500,01187300,01121000$ \\
\hline 01124390 & 420916 & 715447 & 10 & Little River at Richardson Corners, Mass. & 18 & $01175670,01176000,01111200,01111300,01121000$ \\
\hline 01162900 & 423352 & 720043 & 7 & Otter River at Gardner, Mass. & 18 & $\begin{array}{l}01162500,01165500,01174000,01174900,01175670, \\
01096000\end{array}$ \\
\hline 01163298 & 423549 & 720528 & 7 & Trout Brook at Route 20, near Baldwinville, Mass. & 9 & $01096000,01169000,01170100,01174900$ \\
\hline 01164300 & 424114 & 721039 & 7 & Lawrence Brook at Royalston, Mass. & 14 & $01096000,01162500,01174500,01175670$ \\
\hline 01165090 & 423845 & 721525 & 7 & West Branch Tulley River at North Orange, Mass. & 9 & $01096000,01162500,01174500,01175670$ \\
\hline 01165250 & 423217 & 721451 & 7 & Riceville Brook near South Athol, Mass. & 9 & $01096000,01162500,01174500,01175670,01170100$ \\
\hline 01167200 & 424115 & 723243 & 6 & Fall River at Bernardston, Mass. & 16 & $01169000,01170100,01169900,01162500$ \\
\hline 01168300 & 423812 & 725610 & 3 & Cold River near Zoar, Mass. & 31 & $01169000,01333000,01169900,01170100$ \\
\hline 01168400 & 423728 & 725427 & 3 & Chickley River near Charlemont, Mass. & 22 & $01170100,01169900,01169000,01333000$ \\
\hline 01168650 & 423647 & 724610 & 3 & Clesson Brook near Shelburne Falls, Mass. & 24 & $01169000,01169900,01170100,01333000,01171500$ \\
\hline 01169600 & 423245 & 724315 & 3 & Bear River near Conway, Mass. & 17 & $01169000,01169900,01170100,01171500,01333000$ \\
\hline 01169800 & 422916 & 724447 & 3 & Poland Brook near Burkville, Mass. & 15 & $01169000,01169900,01170100,01333000,01171500$ \\
\hline 01169801 & 424315 & 724437 & 3 & South River at North Poland Road near Burkville, Mass. & 11 & $01169000,01169900,01170100,01333000,01171500$ \\
\hline 01170575 & 423123 & 723224 & 6 & Sawmill Brook near Montague, Mass. & 9 & $01162500,01171500,01169900,01174900,01174500$ \\
\hline 01171947 & 421633 & 723031 & 6 & Bachelor Brook At Granby, Mass. & 10 & $01171500,01174900,01175670,01176000,01184490$ \\
\hline 01171970 & 421508 & 723426 & 6 & Stony Brook at Morgan Street at South Hadley, Mass. & 10 & $\begin{array}{l}01169900,01171500,01174900,01175670,01176000, \\
01181000\end{array}$ \\
\hline 01172810 & 422615 & 720226 & 8 & Canesto Brook near Barre, Mass. & 10 & $01175670,01162500,01176000,01174900$ \\
\hline 01173420 & 421453 & 721559 & 8 & Muddy Brook at Ware, Mass. & 9 & $01176000,01175670,01174900,01174500$ \\
\hline 01173450 & 421456 & 721553 & 8 & Flat Brook near Ware, Mass. & 15 & $01162500,01096000,01171500,01174900,01175670$ \\
\hline 01175710 & 421939 & 720218 & 8 & Five Mile River near North Brookfield, Mass. & 11 & $01174500,01174900,01175670,01176000$ \\
\hline 01175850 & 421550 & 720933 & 8 & Mill River at West Brookfield, Mass. & 12 & $01171500,01176000,01175670,01174900$ \\
\hline 01175890 & 421331 & 721012 & 8 & Naultaug Brook at Warren, Mass. & 14 & $01162500,01174900,01175670,01176000$ \\
\hline 01176100 & 421013 & 721541 & 8 & Blodgett Brook near West Brimfield, Mass & 15 & 01171500,01176000 \\
\hline 01176200 & 420941 & 721608 & 8 & Kings Brook at West Brimfield, Mass. & 14 & $01171500,01176000,01184490,01121000$ \\
\hline 01176300 & 420743 & 721531 & 8 & Foskett Mill Stream near Fentonville, Mass. & 17 & $01171500,01176000,01184490,01121000$ \\
\hline 01176415 & 420535 & 721844 & 8 & Chicopee Brook at Route 32, South Monson, Mass & 10 & $01121000,01174900,01175670,01184490$ \\
\hline 01176780 & 420852 & 722400 & 8 & Twelvemile Brook near North Wilbraham, Mass. & 8 & $01176000,01175670,01171500,01184490,01121000$ \\
\hline 01177360 & 420506 & 722850 & 6 & $\begin{array}{l}\text { South Branch Mill River at Porter Road near East } \\
\text { Longmeadow, Mass. }\end{array}$ & 10 & $01176000,01175670,01174900,01174500,01184490$ \\
\hline
\end{tabular}




\begin{tabular}{|c|c|c|c|c|c|c|}
\hline $\begin{array}{l}\text { Station } \\
\text { No. }\end{array}$ & $\begin{array}{l}\text { Latitude } \\
\text { a," }\end{array}$ & Longitude & $\begin{array}{l}\text { Basin } \\
\text { No. }\end{array}$ & Station name & $\begin{array}{l}\text { Number } \\
\text { of meas- } \\
\text { urements }\end{array}$ & $\begin{array}{l}\text { Gaging stations used for } \\
\text { correlation }\end{array}$ \\
\hline 01178200 & 422841 & 725909 & 4 & Westfield Brook at East Windsor, Mass. & 17 & $01169900,01181000,01171500,01180500,01169000$ \\
\hline 01178300 & 422650 & 725129 & 4 & Swift River at Swift River, Mass. & 18 & $01169900,01181000,01171500,01180500$ \\
\hline 01178490 & 422402 & 725236 & 4 & West Branch at West Chesterfield, Mass. & 8 & $01169000,01169900,01181000,01187300$ \\
\hline 01179900 & 422521 & 725919 & 4 & Trout Brook at West Worthington, Mass. & 9 & $01169900,01171500,01181000$ \\
\hline 01180650 & 421956 & 730509 & 4 & Shaker Mill Brook at Becket, Mass. & 9 & $01169900,01171500,01181000,01199050$ \\
\hline 01183210 & 420705 & 724801 & 4 & Munn Brook near Westfield, Mass. & 9 & $01187300,01181000,01171500,01184490,01188000$ \\
\hline 01184200 & 420231 & 721400 & 6 & Still Brook near West Agawam, Mass. & 18 & $\begin{array}{l}01171500,01181000,01174900,01175670,01184490, \\
01121000\end{array}$ \\
\hline 01184277 & 420254 & 722716 & 6 & Scantic River near Hampden, Mass. & 9 & $01174900,01175670,01176000,01184490$ \\
\hline 01184855 & 420940 & 730419 & 5 & West Branch Farmington River near Otis, Mass. & 10 & $01187300,01171500,01188000,01181000,01199050$ \\
\hline 01185490 & 420603 & 730543 & 5 & Clam River near West New Boston, Mass. & 14 & $01181000,01187300,01188000$ \\
\hline 01186300 & 420237 & 730813 & 5 & Sandy Brook near Sandisfield, Mass. & 14 & $\begin{array}{l}01181000,01187300,01188000,01180500,01199050 \\
\quad 01197000\end{array}$ \\
\hline 01197120 & 422628 & 731747 & 2 & South West Branch Housatonic River at Pittsfield, Mass. & 12 & $01197000,01333000,01181000,01169900$ \\
\hline 01197140 & 422251 & 731526 & 2 & Yokun Brook near Lenox, Mass. & 18 & $01169900,01181000,01199050,01333000$ \\
\hline 01197180 & 421759 & 731253 & 2 & Greenwater Brook at East Lee, Mass. & 14 & $01197000,01181000,01187300,01188000$ \\
\hline 01197230 & 421613 & 731506 & 2 & Hop Brook near South Lee, Mass. & 14 & $01181000,01187300,01188000,01169900,01199050$ \\
\hline 01198060 & 420917 & 732651 & 2 & Fenton Brook near South Egremont, Mass. & 17 & $01181000,01187300,01188000,01999050$ \\
\hline 01198160 & 420526 & 731440 & 2 & Umpachene River at Southfield, Mass. & 17 & $01181000,01188000,01199050$ \\
\hline 01198200 & 420311 & 731935 & 2 & Konkapot River at Ashley Falls, Mass. & 34 & $01181000,01199050,01198000,01198500$ \\
\hline 01331380 & 423340 & 730906 & 1 & South Brook at Windsor Road at Cheshire, Mass. & 14 & $01169000,01169900,01197000,01333000$ \\
\hline 01332900 & 424038 & 731239 & 1 & $\begin{array}{l}\text { Hopper Brook at Hopper Road near South } \\
\text { Williamstown, Mass. }\end{array}$ & 15 & $01169000,01169900,01333000$ \\
\hline 01333100 & 424116 & 731350 & 1 & Hemlock Brook near Williamstown, Mass. & 14 & 01333000,01332000 \\
\hline 01359967 & 423219 & 732001 & 1 & Kinderhook Creek at Hancock, Mass. & 9 & $01197000,01333000,01199050,01198000$ \\
\hline
\end{tabular}


Table 9. Streamflow statistics, variances, standard errors, and years of record for stations included in the regression analyses; streamflow statistics are computed from daily records for streamgaging stations and estimated for low-flow partial-record stations; equivalent years of record for low-flow partial-record stations are computed from equation 14

[Streamflow is in cubic feet per second; variance is in units of base-10 logarithms; standand error is in percent. No., number; --, station not used in analysis because standard error of estimate was too large or it was an outlier]

\begin{tabular}{|c|c|c|c|c|c|c|c|c|c|c|c|c|c|c|}
\hline \multirow{2}{*}{$\begin{array}{c}\text { Station } \\
\text { No. }\end{array}$} & \multirow{2}{*}{ Statistic } & \multicolumn{10}{|c|}{ Flow-duration percentile } & \multirow{2}{*}{$\begin{array}{l}\text { August } \\
\text { median }\end{array}$} & \multirow{2}{*}{$\begin{array}{l}\text { 7-Day, } \\
\text { 10-year } \\
\text { low flow }\end{array}$} & \multirow{2}{*}{$\begin{array}{l}\text { 7-Day, } \\
\text { 2-year } \\
\text { low flow }\end{array}$} \\
\hline & & 99 & 98 & 95 & 90 & 85 & 80 & 75 & 70 & 60 & 50 & & & \\
\hline \multirow[t]{4}{*}{01073860} & Streamflow & 0.17 & 0.18 & 0.23 & 0.28 & 0.33 & 0.38 & 0.44 & 0.51 & -- & - & 0.34 & 0.15 & 0.23 \\
\hline & Variance & .00303 & .00229 & .00118 & .00063 & .00058 & .00079 & .00124 & .00270 & $\cdots$ & -- & .00061 & .01182 & .00123 \\
\hline & Standard error & 12.7 & 11.1 & 7.9 & 5.8 & 5.6 & 6.5 & 8.1 & 12.0 & -- & -- & 5.7 & 25.4 & 8.1 \\
\hline & Years & 27.2 & 27.9 & 31.3 & 37.3 & 37.6 & 30.2 & 19.6 & 8.0 & $\cdots$ & $\cdots$ & 17.9 & 3.5 & 5.5 \\
\hline \multirow[t]{4}{*}{01094340} & Streamflow & 1.05 & 1.33 & 2.21 & 3.78 & 5.40 & 7.53 & 10.0 & 13.0 & -- & -. & 5.82 & .89 & 2.29 \\
\hline & Variance & .0096 & .00706 & .00353 & .00175 & .00146 & .00185 & .00269 & .00384 & -- & -- & .00152 & .01182 & .00376 \\
\hline & Standard error & 22.9 & 19.5 & 13.7 & 9.7 & 8.8 & 9.9 & 12.0 & 14.3 & - & -- & 9.0 & 25.4 & 14.2 \\
\hline & Years & 17.2 & 19.3 & 26.7 & 36 & 37.1 & 29.5 & 19.9 & 13.6 & -- & -- & 21.7 & 3.5 & 7.1 \\
\hline \multirow[t]{4}{*}{01094396} & Streanflow & .44 & .58 & 1.04 & 1.69 & 2.20 & 2.95 & .. & - & -- & -- & 2.34 & .34 & 1.08 \\
\hline & Variance & .0093 & .00636 & .00301 & .00241 & .00262 & .00339 & -- & - & -- & -- & .00279 & .01167 & .00373 \\
\hline & Standard error & 22.5 & 18.5 & 12.7 & 11.3 & 11.8 & 13.5 & -- & -- & -- & - & 12.2 & 25.3 & 14.1 \\
\hline & Years & 19.6 & 25.1 & 37.9 & 33.3 & 25.5 & 19.8 & $\cdot$ & - & -- & $\cdots$ & 15.8 & 5.8 & 13.2 \\
\hline \multirow[t]{4}{*}{01094760} & Streamflow & .082 & .12 & .22 & .43 & .64 & .98 & 1.42 & 1.95 & 3.53 & -- & .67 & .056 & .23 \\
\hline & Variance & .0061 & .00468 & .00272 & .0016 & .00133 & .00141 & .00176 & .00228 & .00381 & -- & .00141 & .01201 & .00481 \\
\hline & Standard error & 18.1 & 15.9 & 12.1 & 9.2 & 8.4 & 8.7 & 9.7 & 11.0 & 14.3 & -- & 8.7 & 25.6 & 16.1 \\
\hline & Years & 27.4 & 28.2 & 30.2 & 31.8 & 31.9 & 31.1 & 29.1 & 26.4 & 19.9 & -- & 26.1 & 13.4 & 17.3 \\
\hline \multirow[t]{4}{*}{01095220} & Streamflow & 1.23 & 1.65 & 2.79 & 4.39 & 5.99 & 7.97 & 10.1 & 12.7 & 19.6 & 28.9 & 6.42 & 1.06 & 2.73 \\
\hline & Variance & .00109 & .0009 & .00061 & .00042 & .00034 & .00028 & .00026 & .00026 & .0003 & .00037 & .00035 & .00271 & .00138 \\
\hline & Standard error & 7.6 & 6.9 & 5.7 & 4.7 & 4.2 & 3.9 & 3.7 & 3.7 & 4.0 & 4.4 & 4.3 & 12.0 & 8.6 \\
\hline & Years & 42.8 & 43.5 & 44 & 43.9 & 43.8 & 43.8 & 43.7 & 43.1 & 41.9 & 40.2 & 38.4 & 25.4 & 26.1 \\
\hline \multirow[t]{4}{*}{01095380} & Streamflow & .061 & .10 & -- & -- & .83 & 1.35 & 2.09 & 3.06 & -- & -- & .94 & .051 & .22 \\
\hline & Variance & .00681 & .00472 & $-\cdot$ & $\cdots$ & .00079 & .0012 & .00195 & .00289 & -- & -- & .00093 & .01092 & .00357 \\
\hline & Standard error & 19.2 & 15.9 & -- & -- & 6.5 & 8.0 & 10.2 & 12.4 & -- & -- & 7.0 & 24.4 & 13.8 \\
\hline & Years & 35.6 & 39 & - & .. & 49.6 & 43.8 & 37.1 & 31.2 & $\cdots$ & - & 41.2 & 13.4 & 20.8 \\
\hline \multirow[t]{4}{*}{01095915} & Streamflow & .44 & .61 & 1.09 & 1.82 & 2.52 & 3.52 & 4.77 & 6.16 & 10.7 & 17.4 & 2.73 & .39 & 1.06 \\
\hline & Variance & .00454 & .00338 & .0018 & .001 & .00078 & .0008 & .00102 & .00135 & .00252 & .00403 & .00083 & .00973 & .00408 \\
\hline & Standard error & 15.6 & 13.4 & 9.8 & 7.3 & 6.4 & 6.5 & 7.4 & 8.5 & 11.6 & 14.7 & 6.6 & 23.0 & 14.8 \\
\hline & Years & 35.5 & 36.4 & 38.2 & 39.7 & 39.9 & 39.1 & 36.7 & 33.9 & 26.4 & 20.6 & 34 & 19.8 & 21.1 \\
\hline \multirow[t]{4}{*}{01095928} & Streamflow & .030 & .054 & .16 & .36 & .65 & 1.15 & 1.82 & - & $\ldots$ & -- & .74 & .020 & .16 \\
\hline & Variance & .00463 & .00336 & .00204 & .00182 & .0021 & .00276 & .00352 & $\cdots$ & -- & -- & .00236 & .01072 & .00479 \\
\hline & Standard error & 15.8 & 13.4 & 10.4 & 9.8 & 10.6 & 12.1 & 13.7 & -- & -- & - & 11.2 & 24.2 & 16.0 \\
\hline & Years & 38.8 & 41.8 & 43.5 & 40.4 & 36.6 & 32.4 & 28.6 & -- & - & - & 29.6 & 22.5 & 28.1 \\
\hline
\end{tabular}


Table 9. Streamflow statistics, variances, standard errors, and years of record for stations included in the regression analyses; streamflow statistics are computed from daily records for streamgaging stations and estimated for low-flow partial-record stations; equivalent years of record for low-flow partial-record stations are computed from equation 14-Continued

\begin{tabular}{|c|c|c|c|c|c|c|c|c|c|c|c|c|c|c|}
\hline \multirow{2}{*}{$\begin{array}{c}\text { Station } \\
\text { No. }\end{array}$} & \multirow{2}{*}{ Statistic } & \multicolumn{10}{|c|}{ Flow-duration percentile } & \multirow{2}{*}{$\begin{array}{l}\text { August } \\
\text { median }\end{array}$} & \multirow{2}{*}{$\begin{array}{l}\text { 7-Day, } \\
\text { 10-year } \\
\text { low flow }\end{array}$} & \multirow{2}{*}{$\begin{array}{l}\text { 7-Day, } \\
\text { 2-year } \\
\text { low flow }\end{array}$} \\
\hline & & 99 & 98 & 95 & 90 & 85 & 80 & 75 & 70 & 60 & 50 & & & \\
\hline \multirow[t]{4}{*}{01096000} & Streamflow & 6.40 & 7.80 & 11.0 & 15.0 & 18.0 & 22.0 & 27.0 & 32.0 & 48.0 & 69.0 & 19.0 & 6.52 & 11.7 \\
\hline & Variance & .00005 & .00004 & .00003 & .00002 & .00002 & .00002 & .00002 & .00001 & .00001 & .00001 & .00007 & .00467 & .00256 \\
\hline & Standard error & 1.6 & 1.5 & 1.3 & 1.1 & 1.0 & 1.0 & .9 & .9 & .8 & .8 & 2.0 & 15.8 & 11.7 \\
\hline & Years & 47 & 47 & 47 & 47 & 47 & 47 & 47 & 47 & 47 & 47 & 47 & 47 & 47 \\
\hline \multirow[t]{4}{*}{01096504} & Streamflow & .26 & .31 & .45 & .63 & .77 & .92 & 1.08 & 1.25 & 1.60 & 2.00 & .81 & .24 & .46 \\
\hline & Variance & .00307 & .00207 & .00078 & .00029 & .00032 & .00056 & .00092 & .00138 & .00242 & .00359 & .00037 & .00405 & .00095 \\
\hline & Standard error & 12.8 & 10.5 & 6.4 & 3.9 & 4.1 & 5.5 & 7.0 & 8.6 & 11.4 & 13.9 & 4.4 & 14.7 & 7.1 \\
\hline & Years & 26.9 & 31.1 & 46.5 & 65.1 & 57.5 & 40.7 & 27.3 & 18.7 & 10 & 6.7 & 36.8 & 9.4 & 18.3 \\
\hline \multirow[t]{4}{*}{01096505} & Streamflow & .50 & .64 & .97 & $1.4 \mathrm{I}$ & 1.82 & 2.34 & 2.89 & 3.50 & 4.98 & 6.80 & 1.94 & .46 & .97 \\
\hline & Variance & .0027 & .00203 & .00118 & .00071 & .00057 & .00056 & .00064 & .00078 & .00123 & .00181 & .00057 & .00395 & .00161 \\
\hline & Standard error & 12.0 & 10.4 & 7.9 & 6.1 & 5.5 & 5.5. & 5.8 & 6.4 & 8.1 & 9.8 & 5.5 & 14.5 & 9.3 \\
\hline & Years & 36.9 & 38.9 & 43.1 & 46.8 & 48 & 46.3 & 42.3 & 37.4 & 27.9 & 21.1 & 34.8 & 15.8 & 18.4 \\
\hline \multirow[t]{4}{*}{01096515} & Streamflow & 2.55 & 3.06 & 4.32 & 5.98 & 7.41 & 9.18 & 11.2 & 13.3 & 18.6 & 25.0 & 7.76 & 2.34 & 4.49 \\
\hline & Variance & .00262 & .00196 & .00114 & .00081 & .00081 & .00096 & .00125 & .00162 & .00261 & .00378 & .00084 & .00337 & .00132 \\
\hline & Standard error & 11.8 & 10.2 & 7.8 & 6.6 & 6.6 & 7.1 & 8.2 & 9.3 & 11.8 & 14.2 & 6.7 & 13.4 & 8.4 \\
\hline & Years & 34.9 & 37.1 & 42.2 & 41.7 & 37.1 & 31.6 & 25.5 & 20.5 & 12.6 & 8.5 & 21.7 & 8.3 & 11.8 \\
\hline \multirow[t]{4}{*}{01096805} & Streamflow & .65 & .77 & 1.19 & 1.85 & 2.62 & $\cdot 3.50$ & 4.53 & 5.61 & 8.34 & 11.7 & 2.73 & .54 & 1.09 \\
\hline & Variance & .00413 & .00327 & .00177 & .00095 & .00078 & .00091 & .00125 & .0017 & .00287 & .00408 & .00084 & .00687 & .00287 \\
\hline & Standard error & 14.9 & 13.2 & 9.7 & 7.1 & 6.4 & 7.0 & 8.2 & 9.5 & 12.4 & 14.8 & 6.7 & 19.3 & 12.4 \\
\hline & Years & 29.1 & 29.4 & 32 & 35.6 & 38.3 & 38.6 & 32.1 & 26.7 & 19.7 & 16.4 & 32 & 11.2 & 13.3 \\
\hline \multirow[t]{4}{*}{01096855} & Streamflow & .16 & .18 & .26 & .39 & .50 & .65 & .82 & 1.02 & -- & - & .53 & .14 & .25 \\
\hline & Variance & .00549 & .00408 & .00206 & .00119 & .00121 & .00162 & .00239 & .00337 & - & -- & .00129 & .00728 & .00247 \\
\hline & Standard error & 17.2 & 14.8 & 10.5 & 8.0 & 8.0 & 9.3 & 11.3 & $\cdot 13.4$ & -- & - & 8.3 & 19.8 & 11.5 \\
\hline & Years & 18.5 & 20.6 & 27.8 & 32.9 & 30 & 23.4 & 16 & 11.3 & -- & -- & 18.5 & 4.4 & 7.4 \\
\hline \multirow[t]{4}{*}{01096910} & Streamflow & .040 & .060 & .10 & .15 & .24 & .34 & .47 & .69 & 1.30 & 2.20 & .22 & - &.- \\
\hline & Variance & .00039 & .00032 & .00025 & .00019 & .00016 & .00014 & .00013 & .00012 & .00011 & .00010 & .00088 & -- & -- \\
\hline & Standard error & 4.5 & 4.2 & 3.6 & 3.2 & 2.9 & 2.7 & 2.6 & 2.5 & 2.4 & 2.4 & 6.8 & -- & -- \\
\hline & Years & 11 & 11 & 11 & 11 & 11 & 11 & 11 & 11 & 11 & 11 & 11 & $\because$ & -- \\
\hline \multirow[t]{4}{*}{01096935} & Streamflow & .91 & 1.07 & 1.54 & 2.39 & 3.19 & 4.05 & 5.24 & 6.69 & 10.5 & -- & 3.36 & .76 & 1.55 \\
\hline & Variance & .00726 & .0056 & .00307 & .00136 & .00082 & .00068 & .00089 & .00141 & .00312 & -- & .00078 & .0098 & .00348 \\
\hline & Standard error & 19.8 & 17.4 & 12.8 & 8.5 & 6.6 & 6.0 & 6.9 & 8.7 & 12.9 & -- & 6.4 & 23.1 & 13.6 \\
\hline & Years & 16.1 & 17.1 & 21.7 & 29.9 & 34.3 & 36.2 & 30.9 & 23.9 & 12.8 & -- & 26.6 & 3.6 & 6.1 \\
\hline
\end{tabular}


Table 9. Streamflow statistics, variances, standard errors, and years of record for stations included in the regression analyses; streamflow statistics are computed from daily records for streamgaging stations and estimated for low-flow partial-record stations; equivalent years of record for low-flow partial-record stations are computed from equation 14-Continued

\begin{tabular}{|c|c|c|c|c|c|c|c|c|c|c|c|c|c|c|}
\hline \multirow{2}{*}{$\begin{array}{c}\text { Station } \\
\text { No. }\end{array}$} & \multirow{2}{*}{ Statistic } & \multicolumn{10}{|c|}{ Flow-duration percentile } & \multirow{2}{*}{$\begin{array}{l}\text { August } \\
\text { median }\end{array}$} & \multirow{2}{*}{$\begin{array}{l}\text { 7-Day, } \\
\text { 10-year } \\
\text { low flow }\end{array}$} & \multirow{2}{*}{$\begin{array}{l}\text { 7-Day, } \\
\text { 2-year } \\
\text { low flow }\end{array}$} \\
\hline & & 99 & 98 & 95 & 90 & 85 & 80 & 75 & 70 & 60 & 50 & & & \\
\hline \multirow[t]{4}{*}{01097280} & Streamflow & 1.11 & 1.33 & 1.78 & 2.60 & 3.42 & 4.40 & 5.49 & 6.77 & -- & 13.0 & 3.65 & 0.89 & 1.83 \\
\hline & Variance & .00382 & .00292 & .00176 & .0009 & .00063 & .00062 & .00079 & .00113 & -- & .00316 & .00063 & .00574 & .002 \\
\hline & Standard error & 14.3 & 12.5 & 9.7 & 6.9 & 5.8 & 5.7 & 6.5 & 7.8 & -. & 13.0 & 5.8 & 17.6 & 10.3 \\
\hline & Years & 21.6 & 22.7 & 26 & 32 & 34.9 & 33.7 & 29 & 22.9 & -- & 10 & 25.6 & 4 & 7.2 \\
\hline \multirow[t]{4}{*}{01097300} & Streamflow & .19 & .29 & .71 & 1.40 & 2.10 & 3.10 & 4.10 & 5.20 & 7.90 & 12.0 & 2.30 & .12 & -- \\
\hline & Variance & .00012 & .00010 & .00008 & .00006 & .00005 & .00004 & .00004 & .00004 & .00003 & .00003 & .00036 & .01480 & .. \\
\hline & Standard error & 2.5 & 2.3 & 2.0 & 1.8 & 1.6 & 1.5 & 1.5 & 1.4 & 1.3 & 1.3 & 4.4 & 28.6 & -- \\
\hline & Years & 32 & 32 & 32 & 32 & 32 & 32 & 32 & 32 & 32 & 32 & 32 & 32 & -- \\
\hline \multirow[t]{4}{*}{01099400} & Streamflow & 1.17 & 1.61 & 2.54 & 4.22 & 5.93 & 8.28 & 11.0 & 14.2 & -- & -- & 6.52 & .98 & 2.45 \\
\hline & Variance & .01153 & .0081 & .00399 & .00175 & .00128 & .00151 & .00221 & .00322 & -- & - & .00134 & .01505 & .00483 \\
\hline & Standard error & 25.1 & 20.9 & 14.6 & 9.7 & 8.3 & 9.0 & 10.9 & 13.1 & .. & -- & 8.4 & 28.8 & 16.1 \\
\hline & Years & 16.8 & 19.1 & 24.7 & 33 & 37.8 & 39.6 & 28.3 & 19.6 & -- & -- & 27.6 & 3.8 & 7 \\
\hline \multirow[t]{4}{*}{01100608} & Streamflow & .18 & .24 & .36 & .55 & .73 & .96 & 1.23 & 1.52 & -- & -- & .78 & .15 & .36 \\
\hline & Variance & .00535 & .00387 & .00218 & .00148 & .00154 & .00196 & .00262 & .00343 & .. & -- & .00162 & .0071 & .00248 \\
\hline & Standard error & 17.0 & 14.4 & 10.8 & 8.9 & 9.1 & 10.2 & 11.8 & 13.5 & -- & -- & 9.3 & 19.6 & 11.5 \\
\hline & Years & 29.8 & 32 & 37 & 39.9 & 34.8 & 26.5 & 18.9 & 14.1 & -- & -- & 19.7 & 4.6 & 7.6 \\
\hline \multirow[t]{4}{*}{01100700} & Streamflow & .15 & .22 & .41 & .60 & .78 & 1.10 & 1.40 & 1.80 & 3.20 & 4.90 & .67 & .15 & .36 \\
\hline & Variance & .00033 & .00028 & .00021 & .00016 & .00014 & .00012 & .00011 & .00010 & .00009 & .00009 & .00046 & .01102 & .00605 \\
\hline & Standard error & 4.2 & 3.9 & 3.4 & 2.9 & 2.7 & 2.5 & 2.4 & 2.3 & 2.2 & 2.2 & 5.0 & 24.5 & 18.1 \\
\hline & Years & 11 & 11 & 11 & 11 & 11 & 11 & 11 & 11 & 11 & 11 & 11 & 11 & 11 \\
\hline \multirow[t]{4}{*}{01101000} & Streamflow & -- & $\cdots$ & .. & -- & -- & .. & 6.00 & 8.70 & 15.0 & 23.0 & .. & -- & -- \\
\hline & Variance & $\ldots$ & - & -- & -- & -. & -- & .0000322 & .0000298 & .0000271 & .00003 & -- & -- & - \\
\hline & Standard error & -- & - & -- & -- & -- & -- & 1.3 & 1.3 & 1.2 & 1.2 & .. & -- & -- \\
\hline & Years & -- & - & -- & - & -- & - & 50 & 50 & 50 & 50 & -- & -. & -- \\
\hline \multirow[t]{4}{*}{01101100} & Streamflow & .45 & .53 & .77 & 1.20 & 1.55 & 1.93 & 2.32 & 2.81 & 3.76 & 4.75 & 1.64 & .39 & .81 \\
\hline & Variance & .00337 & .00254 & .00128 & .0006 & .00059 & .0008 & .00113 & .00164 & .00271 & .00382 & .00066 & .00537 & .00188 \\
\hline & Standard error & 13.4 & 11.6 & 8.3 & 5.6 & 5.6 & 6.5 & 7.8 & 9.3 & 12.0 & 14.3 & 5.9 & 17.0 & 10.0 \\
\hline & Years & 31.9 & 33.2 & 37.3 & 42 & 40.7 & 36.5 & 31.1 & 25.4 & 18.7 & 15 & 31.4 & 12.3 & 18.9 \\
\hline \multirow[t]{4}{*}{01102053} & Streamflow & .46 & .49 & .57 & .69 & .78 & .94 & 1.13 & 1.36 & 2.00 & 2.85 & .84 & .. & .58 \\
\hline & Variance & .00104 & .00074 & .00038 & .00026 & .00031 & .00045 & .00067 & .00091 & .00154 & .00224 & .00035 & .. & .00066 \\
\hline & Standard error & 7.4 & 6.3 & 4.5 & 3.7 & 4.1 & 4.9 & 6.0 & 7.0 & 9.1 & 10.9 & 4.3 & -. & 5.9 \\
\hline & Years & 28.6 & 30.8 & 35.6 & 38.1 & 35.9 & 30.9 & 24.6 & 19.9 & 11.7 & 7.8 & 26.7 & -- & 16.6 \\
\hline
\end{tabular}


Table 9. Streamflow statistics, variances, standard errors, and years of record for stations included in the regression analyses; streamflow statistics are computed from daily records for streamgaging stations and estimated for low-flow partial-record stations; equivalent years of record for low-flow partial-record stations are computed from equation 14-Continued

\begin{tabular}{|c|c|c|c|c|c|c|c|c|c|c|c|c|c|c|}
\hline \multirow{2}{*}{$\begin{array}{c}\text { Station } \\
\text { No. }\end{array}$} & \multirow{2}{*}{ Statistic } & \multicolumn{10}{|c|}{ Flow-duration percentile } & \multirow{2}{*}{$\begin{array}{l}\text { August } \\
\text { median }\end{array}$} & \multirow{2}{*}{$\begin{array}{l}\text { 7-Day, } \\
\text { 10-year } \\
\text { low flow }\end{array}$} & \multirow{2}{*}{$\begin{array}{l}\text { 7-Day, } \\
\text { 2-year } \\
\text { low flow }\end{array}$} \\
\hline & & 99 & 98 & 95 & 90 & 85 & 80 & 75 & 70 & 60 & 50 & & & \\
\hline \multirow[t]{4}{*}{01102490} & Streamflow & 0.19 & 0.24 & 0.36 & 0.58 & 0.77 & 0.99 & 1.20 & 1.45 & -- & -- & 0.83 & 0.17 & 0.37 \\
\hline & Variance & .0044 & .00321 & .00172 & .00108 & .00121 & .00167 & .00223 & .00293 & -- & -. & .00134 & .00623 & .00217 \\
\hline & Standard error & 15.4 & 13.1 & 9.6 & 7.6 & 8.0 & 9.4 & 10.9 & 12.5 & -- & -- & 8.4 & 18.3 & 10.8 \\
\hline & Years & 26.6 & 28.1 & 32.6 & 35.8 & 31.9 & 25.8 & 20.6 & 16.2 & -- & -. & 22 & 8.3 & 12.6 \\
\hline \multirow[t]{4}{*}{01103015} & Streamflow & .45 & .57 & .87 & 1.29 & 1.64 & 2.04 & 2.41 & 2.79 & 3.60 & 4.48 & 1.76 & .38 & .84 \\
\hline & Variance & .00441 & .00326 & .00172 & .00087 & .00064 & .00061 & .00071 & .00087 & .00135 & .00194 & .00064 & .00618 & .00227 \\
\hline & Standard error & 15.4 & 13.2 & 9.6 & 6.8 & 5.8 & 5.7 & 6.1 & 6.8 & 8.5 & 10.2 & 5.8 & 18.3 & 11.0 \\
\hline & Years & 20.7 & 22.3 & 26.8 & 31.9 & 33.7 & 33 & 30.2 & 26.4 & 19.6 & 15 & 27.2 & 5.8 & 9.3 \\
\hline \multirow[t]{4}{*}{01103253} & Streamflow & .26 & .32 & .46 & .72 & .99 & 1.36 & 1.86 & 2.53 & 4.18 & 6.41 & 1.04 & .18 & .48 \\
\hline & Variance & .00185 & .00146 & .00098 & .00062 & .00052 & .00055 & .0007 & .00097 & .00168 & .00252 & .00056 & .00408 & .00176 \\
\hline & Standard error & 9.9 & 8.8 & 7.2 & 5.7 & 5.3 & 5.4 & 6.1 & 7.2 & 9.5 & 11.6 & 5.5 & 14.8 & 9.7 \\
\hline & Years & 34.6 & 34.8 & 36.8 & 38.2 & 38.7 & 37.2 & 33.7 & 29.6 & 23.3 & 19.3 & 31.1 & 11.8 & 15.6 \\
\hline \multirow[t]{4}{*}{01103435} & Streamflow & .25 & .33 & .51 & .96 & 1.46 & 2.05 & 2.94 & 4.68 & 10.1 & -- & 1.51 & .13 & .54 \\
\hline & Variance & .00867 & .00685 & .00442 & .00236 & .00167 & .00142 & .00147 & .00207 & .0042 & -- & .00164 & .01605 & .00612 \\
\hline & Standard error & 21.7 & 19.2 & 15.4 & 11.2 & 9.4 & 8.7 & 8.8 & 10.5 & 15.0 & -- & 9.3 & 29.8 & 18.2 \\
\hline & Years & 22.3 & 22.7 & 23.9 & 27.7 & 29.3 & 29.7 & 28.7 & 25.3 & 19.3 & -- & 24.9 & 7.1 & 10.2 \\
\hline \multirow[t]{4}{*}{01103440} & Streamflow & .15 & .19 & .30 & .50 & .70 & .95 & 1.27 & 1.70 & 2.74 & -- & .74 & .11 & .31 \\
\hline & Variance & .00397 & .00309 & .00192 & .00129 & .00117 & .0013 & .00162 & .00215 & .00349 & -- & .00121 & .00675 & .00259 \\
\hline & Standard error & 14.6 & 12.9 & 10.1 & 8.3 & 7.9 & 8.3 & 9.3 & 10.7 & 13.7 & -- & 8.0 & 19.1 & 11.8 \\
\hline & Years & 29.7 & 30.6 & 33.9 & 35.2 & 34.1 & 31.6 & 27.8 & 23.5 & 16.7 & -- & 24.7 & 7.8 & 12.4 \\
\hline \multirow[t]{4}{*}{01104960} & Streamflow & .10 & .13 & .19 & .28 & .37 & .49 & .63 & .81 & 1.19 & 1.66 & .40 & .079 & .19 \\
\hline & Variance & .00237 & .00196 & .00139 & .00092 & .0007 & .00057 & .00053 & .00054 & .00068 & .00093 & .00069 & .00369 & .00176 \\
\hline & Standard error & 11.2 & 10.2 & 8.6 & 7.0 & 6.1 & 5.5 & 5.3 & 5.4 & 6.0 & 7.0 & 6.1 & 14.1 & 9.7 \\
\hline & Years & 27 & 27.1 & 28.1 & 29.7 & 31 & 32 & 32.5 & 32.1 & 28.6 & 24.4 & 23.9 & 7.8 & 9.6 \\
\hline \multirow[t]{4}{*}{01104980} & Streamflow & .38 & .47 & .67 & 1.05 & 1.51 & 2.07 & 2.71 & 3.60 & 5.85 & 8.93 & 1.71 & .29 & .66 \\
\hline & Variance & .00214 & .00179 & .0013 & .00085 & .00059 & .00043 & .00033 & .00027 & .00028 & .00042 & .00058 & .00418 & .00206 \\
\hline & Standard error & 10.7 & 9.8 & 8.3 & 6.7 & 5.6 & 4.8 & 4.2 & 3.8 & 3.9 & 4.7 & 5.5 & 15.0 & 10.5 \\
\hline & Years & 25.6 & 25.6 & 26.1 & 27.2 & 28.3 & 29.1 & 29.7 & 29.9 & 29.1 & 27.3 & 24.7 & 11.2 & 11.2 \\
\hline \multirow[t]{4}{*}{01105100} & Streamflow & -. & - & -- & 1.86 & 2.04 & 2.26 & - & 2.84 & 3.40 & 3.99 & 2.13 & -- & -- \\
\hline & Variance & -. & - & -- & .00011 & .00009 & .00009 & -- & .00012 & .00018 & .00025 & .0001 & -- & -- \\
\hline & Standard error & $\cdots$ & -. & -- & 2.4 & 2.2 & 2.2 & -- & 2.5 & 3.1 & 3.6 & 2.3 & -- & -- \\
\hline & Years & -- & -- & $\cdots$ & 33.4 & 33.3 & 33 & -- & 30.4 & 25.1 & 20.7 & 26.3 & .. & -- \\
\hline
\end{tabular}


Table 9. Streamflow statistics, variances, standard errors, and years of record for stations included in the regression analyses; streamflow statistics are computed from daily records for streamgaging stations and estimated for low-flow partial-record stations; equivalent years of record for low-flow partial-record stations are computed from equation 14-Continued

\begin{tabular}{|c|c|c|c|c|c|c|c|c|c|c|c|c|c|c|}
\hline \multirow{2}{*}{$\begin{array}{c}\text { Station } \\
\text { No. }\end{array}$} & \multirow{2}{*}{ Statistic } & \multicolumn{10}{|c|}{ Flow-duration percentile } & \multirow{2}{*}{$\begin{array}{l}\text { August } \\
\text { median }\end{array}$} & \multirow{2}{*}{$\begin{array}{l}\text { 7-Day, } \\
\text { 10-year } \\
\text { low flow }\end{array}$} & \multirow{2}{*}{$\begin{array}{l}\text { 7-Day, } \\
\text { 2-year } \\
\text { low flow }\end{array}$} \\
\hline & & 99 & 98 & 95 & 90 & 85 & 80 & 75 & 70 & 60 & 50 & & & \\
\hline \multirow[t]{4}{*}{01105270} & Streamflow & -- & - & -- & -- & -- & 2.43 & 2.87 & 3.50 & - & 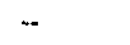 & 2.10 & -- & - \\
\hline & Variance & -- & -- & -- & -- & - & .00332 & .00292 & .00304 & -- & - & .00392 & -- & -- \\
\hline & Standard error & - & -- & -- & -- & - & 13.3 & 12.5 & 12.7 & $\cdots$ & - & 14.5 & -- & -- \\
\hline & Years & -- & -- & - & - & - & 17.2 & 17.2 & 16.7 & -- & -. & 10.4 & -- & -. \\
\hline \multirow[t]{4}{*}{01105568} & Streamflow & 0.12 & 0.15 & 0.25 & 0.38 & 0.53 & -- & - & -- & -- & - & .. & 0.093 & 0.25 \\
\hline & Variance & .00773 & .00535 & .003 & .00266 & .00357 & -- &.- & -. & -- & - & -- & .01132 & .00366 \\
\hline & Standard error & 20.5 & 17.0 & 12.7 & 11.9 & 13.8 & -- & -- & -- & - & - & -. & 24.9 & 14.0 \\
\hline & Years & 25.8 & 27.9 & 29.9 & 25.5 & 19.3 & -- & -- & -- & -- & -- & - & 4.6 & 7.3 \\
\hline \multirow[t]{4}{*}{01105575} & Streamflow & .015 & .025 & .062 & .13 & .22 & .33 & .47 & .64 & 1.16 & 1.87 & .25 & .009 & .055 \\
\hline & Variance & .00805 & .0064 & .00424 & .00293 & .00237 & .00205 & .00192 & .00192 & .00221 & .00272 & .00233 & .01309 & .00627 \\
\hline & Standard error & 20.9 & 18.6 & 15.1 & 12.5 & 11.2 & 10.5 & 10.1 & 10.1 & 10.9 & 12.1 & 11.1 & 26.8 & 18.4 \\
\hline & Years & 24.9 & 25.2 & 26.2 & 27 & 27.4 & 27.7 & 27.9 & 27.8 & 26.1 & 23.7 & 23.4 & 9 & 10.5 \\
\hline \multirow[t]{4}{*}{01105582} & Streamflow & -- & -- & -- & - & 6.92 & 9.83 & 12.4 & -- & -- & -- & 8.15 & - & - \\
\hline & Variance & .. & -- & -- & -- & .00399 & .00357 & .00349 & .. & -- & -- & .00371 & -- & - \\
\hline & Standard error & - &.- & -- & -- & 14.6 & 13.8 & 13.7 & $\cdots$ & -- & -- & 14.1 & - & - \\
\hline & Years & -- & -- & - & $\cdots$ & 31.3 & 30.2 & 33.4 & -- & - & -. & 24.5 & - & - \\
\hline \multirow[t]{4}{*}{01105600} & Streamflow & .20 & .29 & .48 & .83 & 1.20 & 1.70 & 2.20 & 2.71 & 4.10 & 5.40 & 1.40 & .16 & .44 \\
\hline & Variance & .00010 & .00008 & .00006 & .00005 & .00004 & .00004 & .00003 & .00003 & .00003 & .00003 & .00029 & .00525 & .00288 \\
\hline & Standard error & 2.3 & 2.1 & 1.8 & 1.6 & 1.5 & 1.4 & 1.3 & 1.2 & 1.2 & 1.2 & 3.9 & 16.8 & 12.4 \\
\hline & Years & 30 & 30 & 30 & 30 & 30 & 30 & 30 & 30 & 30 & 30 & 30 & 30 & 30 \\
\hline \multirow[t]{4}{*}{01105630} & Streamflow & .35 & .46 & .73 & 1.08 & 1.40 & 1.92 & 2.50 & 3.19 & -- & -- & 1.55 & .27 & .71 \\
\hline & Variance & .00368 & .00234 & .00104 & .00069 & .00083 & .00145 & .00231 & .00336 & -. & -- & .001 & .0061 & .00145 \\
\hline & Standard error & 14.0 & 11.2 & 7.4 & 6.1 & 6.6 & 8.8 & 11.1 & 13.4 & -- & -- & 7.3 & 18.1 & 8.8 \\
\hline & Years & 24.9 & 28.4 & 34.6 & 35.2 & 31.1 & 23.3 & 16.6 & 12.1 & -. & -. & 20.2 & 5.3 & 11.6 \\
\hline \multirow[t]{4}{*}{01105670} & Streamflow & .14 & .17 & .23 & .30 & .36 & .43 & .50 & .58 & - & -- & .41 & -. & -- \\
\hline & Variance & .00729 & .00492 & .0026 & .00145 & .00134 & .00169 & .00226 & .00316 & - & -- & .00147 & -- & -- \\
\hline & Standard error & 19.9 & 16.3 & 11.8 & 8.8 & 8.4 & 9.5 & 11.0 & 13.0 & - & $\cdots$ & 8.8 & -. & - \\
\hline & Years & 13.8 & 15.9 & 19.4 & 22.7 & 22.3 & 19.5 & 15.8 & 11.2 & -- & -- & 15.4 & -- & -- \\
\hline \multirow[t]{4}{*}{01105820} & Streamflow & .047 & .071 & .14 & .26 & .41 & .62 & -. & - & -. & -- & .53 & .033 & .14 \\
\hline & Variance & .0107 & .0073 & .00371 & .00218 & .00226 & .00315 & - & -- & -- & -- & .00279 & .01612 & .00485 \\
\hline & Standard error & 24.2 & 19.9 & 14.1 & 10.8 & 11.0 & 13.0 & - & - & -- & -- & 12.2 & 29.9 & 16.1 \\
\hline & Years & 27.5 & 29.8 & 35.1 & 37.8 & 37.2 & 32.1 & - & -- & - & -- & 24.2 & 5.7 & 10.1 \\
\hline
\end{tabular}


Table 9. Streamflow statistics, variances, standard errors, and years of record for stations included in the regression analyses; streamflow statistics are computed from daily records for streamgaging stations and estimated for low-flow partial-record stations; equivalent years of record for low-flow partial-record stations are computed from equation 14-Continued

\begin{tabular}{|c|c|c|c|c|c|c|c|c|c|c|c|c|c|c|}
\hline \multirow{2}{*}{$\begin{array}{c}\text { Station } \\
\text { No. }\end{array}$} & \multirow{2}{*}{ Statistic } & \multicolumn{10}{|c|}{ Flow-duration percentile } & \multirow{2}{*}{$\begin{array}{l}\text { August } \\
\text { median }\end{array}$} & \multirow{2}{*}{$\begin{array}{l}\text { 7-Day, } \\
\text { 10-year } \\
\text { low flow }\end{array}$} & \multirow{2}{*}{$\begin{array}{l}\text { 7-Day, } \\
\text { 2-year } \\
\text { low flow }\end{array}$} \\
\hline & & 99 & 98 & 95 & 90 & 85 & 80 & 75 & 70 & 60 & 50 & & & \\
\hline \multirow[t]{4}{*}{01105830} & Streamflow & -- & 0.021 & 0.043 & 0.085 & 0.14 & 0.23 & 0.34 & 0.49 & 0.95 & 1.60 & 0.17 & 0.010 & 0.044 \\
\hline & Variance & - & .00427 & .00322 & .0024 & .00195 & .00164 & .00146 & .00136 & .00137 & .00152 & .00191 & .00796 & .00437 \\
\hline & Standard error & -- & 15.1 & 13.1 & 11.3 & 10.2 & 9.3 & 8.8 & 8.5 & 8.5 & 9.0 & 10.1 & 20.8 & 15.3 \\
\hline & Years & $\cdots$ & 31.9 & 32 & 31.8 & 31.9 & 32 & 32.2 & 32.2 & 31.3 & 29.6 & 26.1 & 11.4 & 11.6 \\
\hline \multirow[t]{4}{*}{01105861} & Streamflow & 0,60 & .79 & 1.23 & 1.81 & 2.38 & 2.97 & 3.93 & 5.09 & - & -- & 3.11 & .49 & 1.24 \\
\hline & Variance & .00343 & .00238 & .00148 & .00154 & .00194 & .00252 & .0035 & .00469 & -- & -- & .00261 & .00525 & .00192 \\
\hline & Standard error & .13 .5 & 11.3 & 8.9 & 9.1 & 10.2 & 11.6 & 13.7 & 15.9 & 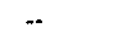 & -- & 11.8 & 16.8 & 10.1 \\
\hline & Years & 39.8 & 41.3 & 41.3 & 34.5 & 28.6 & 24.5 & 19.7 & 15.6 & - & -- & 16.4 & 9.2 & 13.1 \\
\hline \multirow[t]{3}{*}{011058839} & Streamflow & -- & -. & -- & 5.95 & -- & 8.45 & -- & -- & - & 10.6 & - & - & $\cdots$ \\
\hline & Variance & -- & -- & -- & .00298 & -- & .00284 & - & -- & - & .0028 & - & $-\cdot$ & $\cdots$ \\
\hline & Standard error & $\cdots$ & -- & -- & 12.6 & -- & 12.3 & $\cdots$ & -. & $\cdots$ & 12.2 & -- & -- & -- \\
\hline · & Years & - & $\cdots$ & - & 44.4 & - & 38.3 & - & -- & - & 15.6 & - & -- & -- \\
\hline \multirow[t]{4}{*}{011059106} & Streanflow & .090 & .11 & .15 & .22 & .32 & .41 & .52 & .64 & - & - & .41 & .076 & .15 \\
\hline & Variance & .00611 & .00509 & .00368 & .00267 & .0022 & .00196 & .00176 & .00144 & - & -- & .00225 & .00819 & .00413 \\
\hline & Standard error & 18.1 & 16.5 & 14.0 & 11.9 & 10.8 & 10.2 & 9.7 & 8.8 & - & -- & 11.0 & 21.1 & 14.9 \\
\hline & Years & 22.8 & 23.2 & 24.8 & 25.4 & 24.4 & 22.6 & 21.3 & 21.6 & $\cdots$ & -- & 14.4 & 4.4 & 5.4 \\
\hline \multirow[t]{4}{*}{01105930} & Streamflow & .41 & .54 & .91 & 1.53 & 2.29 & 3.34 & 4.63 & -. & .. & -- & 2.71 & .32 & .94 \\
\hline & Variance & .00391 & .00308 & .00196 & .00122 & .00092 & .00083 & .00091 & -- & - & $\cdots$ & .00093 & .00592 & .00266 \\
\hline & Standard error & 14.5 & 12.8 & 10.2 & 8.1 & 7.0 & 6.6 & 7.0 & $\cdots$ & - & -- & 7.0 & 17.9 & 11.9 \\
\hline & Years & 36.1 & 36.2 & 37.7 & 38 & 38.1 & 37.7 & 36.5 & -- & - & -- & 31.7 & 10.3 & 13 \\
\hline \multirow[t]{4}{*}{01105935} & Streamflow & -. & .48 & -- & .98 & -. & -- & - & -- & - & 4.27 & - & -. & - \\
\hline & Variance & -- & .00101 & -- & .00041 & -- & - & - & $\cdots$ & - & .00076 & - & -- & .. \\
\hline & Standard error & $\therefore$ & 7.3 & -- & 4.7 & $*$ & -- & -- & -- & - & 6.4 & -- & - & -- \\
\hline & Years & -- & 36.8 & $\cdot$ & 38.2 & -- & -- & - & -- & - & 26.3 & -- & -- & -- \\
\hline \multirow[t]{4}{*}{01105937} & Streamflow & .085 & .13 & .28 & .60 & 1.05 & 1.76 & 2.80 & 4.25 & 8.78 & -- & 1.29 & .062 & .28 \\
\hline & Variance & .00491 & .00395 & .00257 & .00155 & .00111 & .00093 & .00097 & .00117 & .00183 & -- & .00114 & .00818 & .00382 \\
\hline & Standard error & 16.2 & 14.5 & 11.7 & 9.1 & 7.7 & 7.0 & 7.2 & 7.9 & 9.9 & -- & 7.8 & 21.1 & 14.3 \\
\hline & Years & 35.6 & 35.6 & 36.8 & 37.7 & 38.3 & 38.5 & 38.1 & 36.6 & 31.6 & -- & 34 & 12.5 & 15 \\
\hline \multirow[t]{4}{*}{01105947} & Streamflow & .18 & .26 & .47 & .82 & 1.21 & 1.65 & 2.24 & 3.04 & 5.21 & 8.41 & 1.52 & .14 & .46 \\
\hline & Variance & .00693 & .00543 & .00356 & .00231 & .00176 & .00156 & .00151 & .00166 & .00239 & .00347 & .00161 & .00919 & .00396 \\
\hline & Standard error & 19.3 & 17.1 & 13.8 & 11.1 & 9.7 & 9.1 & 9.0 & 9.4 & 11.3 & 13.6 & 9.3 & 22.3 & 14.6 \\
\hline & Years & 25.8 & 27 & 30.2 & 32.8 & 33.8 & 33 & 30.8 & 27.7 & 22.1 & 17.4 & 24.7 & 5.1 & 6.9 \\
\hline
\end{tabular}


Table 9. Streamflow statistics, variances, standard errors, and years of record for stations included in the regression analyses; streamflow statistics are computed from daily records for streamgaging stations and estimated for low-flow partial-record stations; equivalent years of record for low-flow partial-record stations are computed from equation 14-Continued

\begin{tabular}{|c|c|c|c|c|c|c|c|c|c|c|c|c|c|c|}
\hline \multirow{2}{*}{$\begin{array}{c}\text { Station } \\
\text { No. }\end{array}$} & \multirow{2}{*}{ Statistic } & \multicolumn{10}{|c|}{ Flow-duration percentile } & \multirow{2}{*}{$\begin{array}{l}\text { August } \\
\text { median }\end{array}$} & \multirow{2}{*}{$\begin{array}{c}\text { 7-Day, } \\
\text { 10-year } \\
\text { low flow }\end{array}$} & \multirow{2}{*}{$\begin{array}{l}\text { 7-Day, } \\
\text { 2-year } \\
\text { low flow }\end{array}$} \\
\hline & & 99 & 98 & 95 & 90 & 85 & 80 & 75 & 70 & 60 & 50 & & & \\
\hline \multirow[t]{4}{*}{01106000} & Streamflow & 0.070 & 0.080 & 0.12 & 0.30 & 0.63 & 1.20 & 2.20 & 3.40 & 6.50 & 9.20 & 0.65 & 0.054 & 0.15 \\
\hline & Variance & .00016 & .00013 & .00010 & .00008 & .00007 & .00006 & .00005 & .00005 & .00004 & .00004 & .00050 & .01015 & .00557 \\
\hline & Standard error & 2.9 & 2.7 & 2.3 & 2.0 & 1.9 & 1.8 & 1.7 & 1.6 & 1.5 & 1.5 & 5.2 & 23.5 & 17.3 \\
\hline & Years & 37 & 37 & 37 & 37 & 37 & 37 & 37 & 37 & 37 & 37 & 37 & 37 & 37 \\
\hline \multirow{4}{*}{01106460} & Streamflow & .40 & .50 & .74 & 1.10 & 1.44 & 1.81 & 2.26 & 2.80 & 3.99 & 5.66 & 1.64 & .34 & .76 \\
\hline & Variance & .00162 & .00112 & .00063 & .00057 & .00075 & .00106 & .00146 & .00194 & .00293 & .00415 & .0009 & .00259 & .0009 \\
\hline & Standard error & 9.3 & 7.7 & 5.8 & 5.5 & 6.3 & 7.5 & 8.8 & 10.2 & 12.5 & 14.9 & 6.9 & 11.8 & 6.9 \\
\hline & Years & 42.5 & 45.5 & 48.6 & 45.2 & 37.9 & 29.5 & 22.2 & 16.8 & 10.9 & 7.9 & 21.8 & 8.2 & 14.9 \\
\hline \multirow[t]{4}{*}{01107000} & Streamflow & .020 & .030 & .070 & .17 & .32 & .60 & 1.00 & 1.60 & 3.70 & 5.50 & .19 & -- & -- \\
\hline & Variance & .00059 & .00050 & .00038 & .00029 & .00025 & .00022 & .00020 & .00018 & .00017 & .00016 & .00179 & -- & - \\
\hline & Standard error & 5.6 & 5.1 & 4.5 & 3.9 & 3.6 & 3.4 & 3.2 & 3.1 & 3.0 & 2.9 & 9.8 & -- & -- \\
\hline & Years & 11 & 11 & 11 & 11 & 11 & 11 & 11 & 11 & 11 & 11 & 11 & -- & -- \\
\hline \multirow{4}{*}{01107400} & Streamflow & $\cdots$ & 2.06 & -- & 3.76 & 4.64 & 5.72 & 6.86 & -- & -- & - & 5.01 & 1.32 & 2.73 \\
\hline & Variance & -- & .00058 & -- & .00033 & .00027 & .00023 & .0002 & -- & -- & -- & .00028 & .00137 & .00075 \\
\hline & Standard error & -- & 5.5 & -- & 4.2 & 3.8 & 3.5 & 3.3 & -- & - & -- & 3.9 & 8.5 & 6.3 \\
\hline & Years & -. & 35.3 & -- & 35.3 & 35.5 & 35.8 & 36.5 & -- & -- & -- & 31.2 & 16.8 & 17 \\
\hline \multirow[t]{4}{*}{01108140} & Streamflow & -. & -- & -- & 3.21 & 3.78 & 4.42 & 5.13 & 5.89 & 7.45 & 8.96 & 4.02 & -- & -- \\
\hline & Variance & -- &.- & -- & .00033 & .00035 & .00047 & .00067 & .00093 & .00154 & .00217 & .0004 & -- & -- \\
\hline & Standard error & -- & -- & -- & 4.2 & 4.3 & 5.0 & 6.0 & 7.0 & 9.1 & 10.8 & 4.6 & -- & -- \\
\hline & Years & -- & -- & -- & 42.2 & 39.3 & 33.2 & 25.7 & 19.4 & 11.8 & 8.5 & 25.9 & -- & -- \\
\hline \multirow[t]{4}{*}{01108180} & Streamflow & .60 & .75 & 1.07 & 1.48 & 1.90 & 2.41 & 2.99 & 3.64 & -- & -- & 2.09 & .47 & 1.06 \\
\hline & Variance & .00307 & .00213 & .00116 & .0008 & .00091 & .00131 & .0019 & .00263 & -- & -- & .00106 & .00495 & .00147 \\
\hline & Standard error & 12.8 & 10.7 & 7.9 & 6.5 & 7.0 & 8.3 & 10.1 & 11.8 & - & -- & 7.5 & 16.3 & 8.8 \\
\hline & Years & 27.9 & 30.1 & 34.9 & 36.3 & 32.7 & 26 & 19.3 & 14.3 & -- & - & 20.8 & 5.8 & 10.4 \\
\hline \multirow[t]{4}{*}{01108600} & Streamflow & .036 & .058 & .14 & .32 & .61 & 1.05 & -- & -- & - & -- & .90 & .025 & .15 \\
\hline & Variance & .00441 & .00311 & .00186 & .0018 & .00252 & .0035 & - & -- & -- & -- & .00329 & .00896 & .00354 \\
\hline & Standard error & 15.4 & 12.9 & 10.0 & 9.8 & 11.6 & 13.7 & - & -- & -- & - & 13.3 & 22.1 & 13.8 \\
\hline & Years & 49.5 & 49.4 & 49.5 & 47.9 & 45.3 & 40.8 & -- & -- & -- & - & 32.2 & 19.5 & 25.9 \\
\hline \multirow[t]{4}{*}{01109087} & Streamflow & .84 & 1.11 & 1.84 & 2.99 & 4.22 & 5.95 & 7.98 & 10.4 & 16.3 & 24 & 4.67 & .62 & 1.91 \\
\hline & Variance & .00367 & .0031 & .00221 & .00155 & .0012 & .00093 & .00077 & .00067 & .00062 & .00069 & .00116 & .00578 & .00294 \\
\hline & Standard error & 14.0 & 12.9 & 10.9 & 9.1 & 8.0 & 7.0 & 6.4 & 6.0 & 5.7 & 6.1 & 7.9 & 17.6 & 12.5 \\
\hline & Years & 27.5 & 27.2 & 27.7 & 28.2 & 28.9 & 29.8 & 30.7 & 31.4 & 31.6 & 30.4 & 22.9 & 8.8 & 10.1 \\
\hline
\end{tabular}


Table 9. Streamflow statistics, variances, standard errors, and years of record for stations included in the regression analyses; streamflow statistics are computed from daily records for streamgaging stations and estimated for low-flow partial-record stations; equivalent years of record for low-flow partial-record stations are computed from equation 14-Continued

\begin{tabular}{|c|c|c|c|c|c|c|c|c|c|c|c|c|c|c|}
\hline \multirow{2}{*}{$\begin{array}{c}\text { Station } \\
\text { No. }\end{array}$} & \multirow{2}{*}{ Statistic } & \multicolumn{10}{|c|}{ Flow-duration percentile } & \multirow{2}{*}{$\begin{array}{l}\text { August } \\
\text { median }\end{array}$} & \multirow{2}{*}{$\begin{array}{l}\text { 7-Day, } \\
\text { 10-year } \\
\text { low flow }\end{array}$} & \multirow{2}{*}{$\begin{array}{l}\text { 7-Day, } \\
\text { 2-year } \\
\text { low flow }\end{array}$} \\
\hline & & 99 & 98 & 95 & 90 & 85 & 80 & 75 & 70 & 60 & 50 & & & \\
\hline \multirow[t]{4}{*}{01109090} & Streamflow & 0.14 & 0.19 & 0.34 & 0.58 & 0.86 & 1.24 & 1.80 & 2.53 & $-\infty$ & -- & 1.04 & 0.11 & 0.34 \\
\hline & Variance & .00509 & .00371 & .00212 & .00149 & .00157 & .00213 & .00305 & .00418 & - & .. & .00185 & .00716 & .00254 \\
\hline & Standard enror & 16.5 & 14.1 & 10.6 & 8.9 & 9.1 & 10.7 & 12.8 & 15.0 & - & -- & 9.9 & 19.7 & 11.6 \\
\hline & Years & 29.1 & 31.6 & 36.5 & 38.7 & 35.3 & 28.1 & 20.9 & 15.7 & - & -- & 22.2 & 5.6 & 10 \\
\hline \multirow[t]{4}{*}{01109200} & Streamflow & .. & .. & .090 & .16 & .29 & .48 & .78 & 1.50 & 3.40 & 5.00 & .26 & -- & - \\
\hline & Variance & -- & -- & .00008 & .00006 & .00005 & .00005 & .00004 & .00004 & .00004 & .00003 & .00037 & -. & -- \\
\hline & Standard error & -- & -- & 2.1 & 1.8 & 1.7 & 1.6 & 1.5 & 1.4 & 1.4 & 1.4 & 4.4 & -- & - \\
\hline & Years & -- & -- & 10 & 10 & 10 & 10 & 10 & 10 & 10 & 10 & 10 & -- & .- \\
\hline \multirow[t]{4}{*}{01109225} & Streamflow & .083 & .11 & .19 & .35 & .55 & -- & -- & - & 3.95 & 6.60 & .60 & .065 & .20 \\
\hline & Variance & .00687 & .00591 & .00452 & .00315 & .00238 & -- & -- &.- & .00167 & .00214 & .00228 & .00893 & .00487 \\
\hline & Standard error & 19.3 & 17.8 & 15.6 & 13.0 & 11.3 & - & -. & -- & 9.4 & 10.7 & 11.0 & 22.0 & 16.2 \\
\hline & Years & 33.9 & 33.8 & 34.3 & 35.4 & 36.6 & -- & -- & $-\cdot$ & 34.3 & 29.2 & 24.9 & 6.5 & 7.2 \\
\hline \multirow[t]{4}{*}{01109460} & Streamflow & 1.11 & 1.36 & 1.97 & & 3.84 & 4.74 & 5.48 & 6.29 & 8.36 & 10.9 & 4.13 & .94 & -- \\
\hline & Variance & .00366 & .00289 & .00176 & .00097 & .00066 & .00054 & .0005 & .00049 & .00066 & .00102 & .00063 & .00480 & -- \\
\hline & Standard error & 14.0 & 12.4 & 9.7 & 7.2 & 5.9 & 5.4 & 5.2 & 5.1 & 5.9 & 7.4 & 5.8 & 16.1 & -- \\
\hline & Years & 17.7 & 18.5 & 21.3 & 25.5 & 28.2 & 29.2 & 29.6 & 29.5 & 24.9 & 18.2 & 21.4 & 3.4 & $\cdots$ \\
\hline \multirow[t]{4}{*}{01111142} & Streamflow & .068 & .11 & .21 & .36 & .52 & - & -- & -- & -- & -- & -- & - & .20 \\
\hline & Variance & .01236 & .00839 & .00405 & .00349 & .00422 & -- & -- & - & -- & -- & -. & -- & .00554 \\
\hline & Standard error & 26.0 & 21.3 & 14.7 & 13.7 & 15.0 & -. & -- & -- & -. & -- & -- & - & 17.3 \\
\hline & Years & 20.2 & 23.6 & 28.5 & 27.4 & 23.3 & -- & -- & -. & -- & -- & $-\cdot$ & .. & 9.3 \\
\hline \multirow[t]{4}{*}{01111200} & Streamflow & 2.10 & 2.50 & 3.20 & 4.50 & 6.10 & 7.90 & 10.0 & 13.0 & 20.0 & 29.0 & 6.80 & 1.80 & 3.23 \\
\hline & Variance & .00010 & .00008 & .00006 & .00005 & .00004 & .00004 & .00003 & .00003 & .00003 & .00003 & .00016 & .00290 & .00159 \\
\hline & Standard error & 2.3 & 2.1 & 1.8 & 1.6 & 1.5 & 1.4 & 1.3 & 1.3 & 1.2 & 1.2 & 2.9 & 12.4 & 9.2 \\
\hline & Years & 28 & 28 & 28 & 28 & 28 & 28 & 28 & 28 & 28 & 28 & 28 & 28 & 28 \\
\hline \multirow[t]{4}{*}{01111225} & Streamflow & .78 & .90 & 1.15 & 1.49 & 1.78 & 2.12 & 2.46 & 2.79 & 3.46 & 4.18 & 1.80 & .63 & 1.19 \\
\hline & Variance & .001 & .00071 & .00039 & .00035 & .00048 & .00074 & .00106 & .00141 & .00215 & .00297 & .00051 & .00212 & .00066 \\
\hline & Standard error & 7.3 & 6.1 & 4.5 & 4.3 & 5.0 & 6.3 & 7.5 & 8.7 & 10.7 & 12.6 & 5.2 & 10.6 & 5.9 \\
\hline & Years & 29 & 31 & 34.7 & 31.6 & 25.7 & 19.4 & 14.6 & 11.4 & 7.8 & 5.8 & 18.3 & 8.2 & 14.7 \\
\hline \multirow[t]{4}{*}{01111300} & Streamflow & .50 & .66 & 1.00 & 1.80 & 2.60 & 3.90 & 5.60 & 7.60 & 12.0 & 18.0 & 2.40 & .25 & 1.16 \\
\hline & Variance & .00013 & .00011 & .00008 & .00006 & .00005 & .00005 & .00004 & .00004 & .00004 & .00004 & .00034 & .01227 & .00674 \\
\hline & Standard error & 2.6 & 2.4 & 2.1 & 1.8 & 1.7 & 1.6 & 1.5 & 1.5 & 1.4 & 1.4 & 4.2 & 25.9 & 19.1 \\
\hline & Years & 29 & 29 & 29 & 29 & 29 & 29 & 29 & 29 & 29 & 29 & 29 & 29 & 29 \\
\hline
\end{tabular}


Table 9. Streamflow statistics, variances, standard errors, and years of record for stations included in the regression analyses; streamflow statistics are computed from daily records for streamgaging stations and estimated for low-flow partial-record stations; equivalent years of record for low-flow partial-record stations are computed from equation $14-$ Continued

\begin{tabular}{|c|c|c|c|c|c|c|c|c|c|c|c|c|c|c|}
\hline \multirow{2}{*}{$\begin{array}{c}\text { Station } \\
\text { No. }\end{array}$} & \multirow{2}{*}{ Statistic } & \multicolumn{10}{|c|}{ Flow-duration percentile } & \multirow{2}{*}{$\begin{array}{l}\text { August } \\
\text { median }\end{array}$} & \multirow{2}{*}{$\begin{array}{l}\text { 7-Day, } \\
\text { 10-year } \\
\text { low flow }\end{array}$} & \multirow{2}{*}{$\begin{array}{l}\text { 7-Day, } \\
\text { 2-year } \\
\text { low flow }\end{array}$} \\
\hline & & 99 & 98 & 95 & 90 & 85 & 80 & 75 & 70 & 60 & 50 & & & \\
\hline \multirow[t]{4}{*}{01112190} & Streamflow & 0.19 & 0.24 & 0.36 & 0.57 & 0.78 & 1.05 & 1.37 & 1.74 & 2.56 & -- & 0.79 & 0.14 & 0.39 \\
\hline & Variance & .00505 & .00396 & .0025 & .00167 & .00155 & .00178 & .00227 & .00292 & .00446 & -. & .00162 & .00877 & .00326 \\
\hline & Standard error & 16.5 & 14.6 & 11.6 & 9.4 & 9.1 & 9.7 & 11.0 & 12.5 & 15.5 & -- & 9.3 & 21.8 & 13.2 \\
\hline & Years & 23.5 & 24.1 & 26.1 & 27.4 & 26.7 & 24.5 & 20.9 & 17.2 & 12 & -- & 19.5 & 6.2 & 9.6 \\
\hline \multirow[t]{4}{*}{01123140} & Streanflow & 1.44 & 1.64 & 2.16 & 2.84 & 3.54 & 4.28 & 4.89 & 5.67 & 7.40 & .. & 3.85 & 1.29 & 2.20 \\
\hline & Variance & .00342 & .00253 & .00133 & .00079 & .00081 & .00116 & .00159 & .00222 & .00378 & -- & .00096 & .00439 & .00138 \\
\hline & Standard error & 13.5 & 11.6 & 8.4 & 6.5 & 6.6 & 7.9 & 9.2 & 10.9 & 14.2 & - & 7.1 & 15.3 & 8.6 \\
\hline & Years & 14.9 & 17 & 23.1 & 28 & 25.9 & 19.1 & 15.3 & 10.8 & 5.9 & -- & 12.6 & 2.4 & 5.3 \\
\hline \multirow[t]{4}{*}{01123161} & Streamflow & - & -- & .. & 1.38 & 2.22 & 2.99 & -- & -- & -- & -- & 2.25 & -- & -- \\
\hline & Variance & -- & -. & $-\infty$ & .00342 & .00207 & .00272 & -- & -- & $\cdots$ & -. & .00227 & -- & -- \\
\hline & Standard error & -- & -- & -- & 13.5 & 10.5 & 12.1 & - & -. & -- & -- & 11.0 & - & -- \\
\hline & Years & -- & - & $\cdots$ & 30.5 & 33.4 & 29 & -- & -- & -- & - & 28.2 & -- & $\therefore$ \\
\hline \multirow[t]{4}{*}{01123200} & Streamflow & .10 & .15 & .28 & .50 & .79 & .. & -- & -- & 4.04 & 6.64 & .78 & .086 & .25 \\
\hline & Variance & .002 & .00145 & .00083 & .00059 & .00063 & -- & -- & - & .00228 & .00328 & .00066 & .00325 & .00141 \\
\hline & Standard error & 10.3 & 8.8 & 6.6 & 5.6 & 5.8 & -- & - & - & 11.0 & 13.2 & 5.9 & 13.2 & 8.7 \\
\hline & Years & 51.1 & 52.8 & 55.6 & 56.6 & 55.1 & -. & -- & -- & 31.2 & 24.9 & 45.6 & 17 & 21.1 \\
\hline \multirow[t]{4}{*}{01124390} & Streamflow & .26 & .33 & .50 & .84 & 1.25 & 1.77 & 2.4 & 3.23 & -- & .. & 1.38 & .20 & .52 \\
\hline & Variance & .00789 & .00618 & .00394 & .00247 & .00207 & .00218 & .00263 & .00341 & -- & -- & .00206 & .01033 & .00422 \\
\hline & Standard error & 20.7 & 18.3 & 14.5 & 11.5 & 10.5 & 10.8 & 11.8 & 13.5 & -. & -. & 10.5 & 23.7 & 15.0 \\
\hline & Years & 23.9 & 25.6 & 30.8 & 34.6 & 33.3 & 29.5 & 25 & 20.6 & -- & -- & 20.8 & 4.3 & 6.1 \\
\hline \multirow[t]{4}{*}{01162500} & Streanflow & - & -- & -- & -- & .- & -- & -- & -- & -- & 17.0 & -- & .45 & -- \\
\hline & Variance & -- & -- & -- & -. & -- & -- & $\cdots$ & -- & -- & .00001 & -- & .00357 & -- \\
\hline & Standard error & -- & - & -- & -- & -. & -- & -- & -- & -- & .8 & -- & 13.8 & -- \\
\hline & Years & -- & - & - & -- & -- & -- & .- & -- & -- & 76 & -- & 76 & - \\
\hline \multirow[t]{4}{*}{01162900} & Streamfiow & 2.79 & 3.33 & 4.61 & 6.33 & 8.18 & 10.1 & 12.2 & 14.3 & 19.5 & 25.0 & 8.32 & 2.57 & 4.52 \\
\hline & Variance & .00106 & .00085 & .00057 & .00041 & .00036 & .00038 & .00043 & .0005 & .00072 & .00097 & .00037 & .00148 & .00076 \\
\hline & Standard error & 7.5 & 6.7 & 5.5 & 4.7 & 4.4 & 4.5 & 4.8 & 5.2 & 6.2 & 7.2 & 4.4 & 8.9 & 6.4 \\
\hline & Years & 37.5 & 38 & 38.9 & 39 & 38.1 & 36.3 & 33.6 & 30.5 & 24.2 & 19.8 & 28.2 & 11.7 & 12.4 \\
\hline \multirow[t]{4}{*}{01163250} & Streamflow & .94 & 1.56 & 2.29 & 3.16 & 3.67 & 4.65 & 5.72 & 7.06 & 10.3 & -. & 4.02 & .90 & 2.07 \\
\hline & Variance & .00201 & .00136 & .00065 & .00043 & .00054 & .00089 & .00147 & .00221 & .00409 & -- & .00061 & .00324 & .0012 \\
\hline & Standard error & 10.4 & 8.5 & 5.9 & 4.8 & 5.4 & 6.9 & 8.8 & 10.9 & 14.8 & -- & 5.7 & 13.2 & 8.0 \\
\hline & Years & 33.5 & 35.6 & 40 & 42.5 & 40.6 & 34.1 & 26.2 & 19.9 & 12 & .. & 28.4 & 10.2 & 15.5 \\
\hline
\end{tabular}


Table 9. Streamflow statistics, variances, standard errors, and years of record for stations included in the regression analyses; streamflow statistics are computed from daily records for streamgaging stations and estimated for low-flow partial-record stations; equivalent years of record for low-flow partial-record stations are computed from equation 14-Continued

\begin{tabular}{|c|c|c|c|c|c|c|c|c|c|c|c|c|c|c|}
\hline \multirow{2}{*}{$\begin{array}{c}\text { Station } \\
\text { No. }\end{array}$} & \multirow{2}{*}{ Statistic } & \multicolumn{10}{|c|}{ Flow-duration percentile } & \multirow{2}{*}{$\begin{array}{l}\text { August } \\
\text { median }\end{array}$} & \multirow{2}{*}{$\begin{array}{l}\text { 7-Day, } \\
\text { 10-year } \\
\text { low flow }\end{array}$} & \multirow{2}{*}{$\begin{array}{l}\text { 7-Day, } \\
\text { 2-year } \\
\text { low flow }\end{array}$} \\
\hline & & 99 & 98 & 95 & 90 & 85 & 80 & 75 & 70 & 60 & 50 & & & \\
\hline \multirow[t]{4}{*}{01164300} & Streamflow & 0.35 & 0.52 & 1.02 & 1.77 & 2.65 & 3.80 & 5.11 & $-\cdot$ & 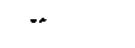 & -- & 2.87 & 0.32 & 1.01 \\
\hline & Variance & .00965 & .0069 & .00389 & .00274 & .00265 & .00309 & .00382 & -- & - & $*$ & .00274 & .01163 & .0046 \\
\hline & Standard error & 22.9 & 19.3 & 14.4 & 12.1 & 11.9 & 12.9 & 14.3 & .. & - & -- & 12.1 & 25.2 & 15.7 \\
\hline & Years & 27 & 29.7 & 34.9 & 35.9 & 33.2 & 28.1 & 22.9 & -- & - & -. & 21.6 & 8.1 & 10.9 \\
\hline \multirow[t]{4}{*}{01165090} & Streamflow & .15 & .20 & $\cdots$ & -- & -- & .. & -. &.- & -. & -- & -- & -- & -- \\
\hline & Variance & .00941 & .00641 & - & - & $\cdots$ & -- & -- & -- & -- & - &.- & .. & $\cdots$ \\
\hline & Standard error & 22.6 & 18.6 & $\cdots$ & -- & -- & -. & $\cdots$ & $\cdot$. & - & -- & -- & -- & -- \\
\hline & Years & 22 & 26.4 & 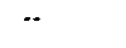 & $\cdots$ & -- & -- & -- & - & - & -- & -- & -- & -- \\
\hline \multirow[t]{4}{*}{01165250} & Streamflow & - & - & .52 & .96 & 1.28 & 1.98 & -- & -- & -- & -- & -- & - & .50 \\
\hline & Variance & $\cdots$ & $\cdots$ & .00159 & .00124 & .00165 & .00259 & -- & -- & -- & -- & -- & $\cdots$ & .0043 \\
\hline & Standard error & - & -- & 9.2 & 8.1 & 9.4 & 11.8 & .. & -. & -- & -- & - & -- & 15.2 \\
\hline & Years & - & - & 46.9 & 43.9 & 39.2 & 34.2 & -- & -- & - & - & - & -- & 25.1 \\
\hline \multirow[t]{4}{*}{01165500} & Streamflow & .70 & .87 & -- & - & -- & -- & -- & -- & 7.40 & 10.0 & -- & -- & -- \\
\hline & Variance & .00005 & .00004 & - & -- & -- & $\cdot \cdot$ & -. & $\cdots$ & .00001 & .00001 & $-\cdot$ & -- & -. \\
\hline & Standard error & 1.6 & 1.4 & $\cdots$ & -- & -- & -- & $\cdots$ & $-\cdot$ & .8 & .8 & -- & -- & -- \\
\hline & Years & 65 & 65 & -- & -- & $-\cdot$ & - & -- & -- & 65 & 65 & - & -- & -- \\
\hline \multirow[t]{4}{*}{01166105} & Streamflow & .99 & 1.10 & 1.40 & 2.00 & 2.50 & 2.90 & 3.40 & 4.00 & 5.10 & 6.30 & 2.60 & -. & -- \\
\hline & Variance & .00030 & .00025 & .00019 & .00015 & .00012 & .00011 & .00010 & .00009 & .00008 & .00008 & .00133 & -- & - \\
\hline & Standard error & 4.0 & 3.6 & 3.2 & 2.8 & 2.6 & 2.4 & 2.3 & 2.2 & 2.1 & 2.1 & 8.4 & -- & -- \\
\hline & Years & 5 & 5 & 5 & 5 & 5 & 5 & 5 & 5 & 5 & 5 & 5 & $-\cdot$ & - \\
\hline \multirow[t]{4}{*}{01167200} & Streamflow & 1.91 & 2.43 & 3.48 & 5.21 & 6.58 & 7.71 & 8.66 & 9.61 & -- & -- & 6.63 & 1.46 & 2.89 \\
\hline & Variance & .0011 & .00097 & .00088 & .00094 & .00103 & .00109 & .00113 & .00112 & -- & -- & .00107 & .00225 & .00144 \\
\hline & Standard error & 7.6 & 7.2 & 6.8 & 7.1 & 7.4 & 7.6 & 7.8 & 7.7 & - & -- & 7.5 & 11.0 & 8.8 \\
\hline & Years & 42.2 & 42.1 & 41.1 & 38.6 & 36.2 & 34.7 & 34.1 & 34.2 & $-\cdot$ & -- & 27.8 & 20.9 & 17.5 \\
\hline \multirow[t]{4}{*}{01168300} & Streamflow & 1.97 & 2.39 & 3.27 & 4.70 & 6.11 & 7.77 & 9.72 & 12.3 & 17.8 & 25.3 & 6.36 & 1.69 & 3.05 \\
\hline & Variance & .00071 & .00055 & .00036 & .00024 & .00021 & .00024 & .0003 & .00041 & .00066 & .001 & .00024 & .00127 & .00063 \\
\hline & Standard error & 6.1 & 5.4 & 4.4 & 3.6 & 3.3 & 3.6 & 4.0 & 4.7 & 5.9 & 7.3 & 3.6 & 8.2 & 5.8 \\
\hline & Years & 43.8 & 44.1 & 45.7 & 47.2 & 47.5 & 46.4 & 44.2 & 41.6 & 36 & 30.8 & 41.6 & 16.9 & 18.7 \\
\hline \multirow[t]{4}{*}{01168400} & Streamflow & $\cdots$ & 4.06 & 5.05 & 6.52 & 7.91 & 9.44 & 11.1 & 13.1 & 17.1 & 22.2 & 8.14 & 3.24 & 4.84 \\
\hline & Variance & $\cdots$ & .00057 & .0003 & .00019 & .00025 & .00041 & .00063 & .00096 & .00165 & .00252 & .00028 & .0012 & .00045 \\
\hline & Standard error & - & 5.5 & 4.0 & 3.2 & 3.6 & 4.7 & 5.8 & 7.1 & 9.4 & 11.6 & 3.9 & 8.0 & 4.9 \\
\hline & Years & - & 49.2 & 55.5 & 61 & 56.4 & 45.6 & 35.3 & 26.6 & 17 & 11.9 & 39.1 & 8.1 & 12 \\
\hline
\end{tabular}


Table 9. Streamflow statistics, variances, standard errors, and years of record for stations included in the regression analyses; streamflow statistics are computed from daily records for streamgaging stations and estimated for low-flow partial-record stations; equivalent years of record for low-flow partial-record stations are computed from equation 14-Continued

\begin{tabular}{|c|c|c|c|c|c|c|c|c|c|c|c|c|c|c|}
\hline \multirow{2}{*}{$\begin{array}{c}\text { Station } \\
\text { No. }\end{array}$} & \multirow{2}{*}{ Statistic } & \multicolumn{10}{|c|}{ Flow-duration percentilo } & \multirow{2}{*}{$\begin{array}{l}\text { August } \\
\text { median }\end{array}$} & \multirow{2}{*}{$\begin{array}{l}\text { 7-Day, } \\
\text { 10-year } \\
\text { low flow }\end{array}$} & \multirow{2}{*}{$\begin{array}{l}\text { 7-Day, } \\
\text { 2-year } \\
\text { low flow }\end{array}$} \\
\hline & & 99 & 98 & 95 & 90 & 85 & 80 & 75 & 70 & 60 & 50 & & & \\
\hline \multirow[t]{4}{*}{01168650} & Streamflow & -- & -- & 4.39 & 5.55 & 6.57 & 7.72 & 8.94 & 10.3 & 13.3 & 17.1 & 6.78 & 2.89 & 4.25 \\
\hline & Variance & -- & -- & .00028 & .0002 & .00026 & .0004 & .0006 & .00087 & .00149 & .00228 & .00028 & .00096 & .00036 \\
\hline & Standard error & -- & -- & 3.9 & 3.3 & 3.7 & 4.6 & 5.6 & 6.8 & 8.9 & 11.0 & 3.9 & 7.1 & 4.4 \\
\hline & Years & - & -- & 68 & 76 & 67.1 & 50.7 & 36.6 & 26.2 & 15.2 & 10 & 37.1 & 7.7 & 11.3 \\
\hline \multirow[t]{4}{*}{01169000} & Streamflow & 9.20 & 11.0 & 15.0 & 21.0 & 27.0 & 33.0 & 40.0 & 49.0 & 68.0 & 92.0 & 27.4 & 8.46 & 13.9 \\
\hline & Variance & .00004 & .00004 & .00003 & .00002 & .00002 & .00002 & .00001 & .00001 & .00001 & .000012 & .00007 & .00118 & .00065 \\
\hline & Standard error & 1.5 & 1.4 & 1.2 & 1.1 & 1.0 & .9 & .9 & .8 & .8 & .8 & 2.0 & 7.9 & 5.9 \\
\hline & Years & 57 & 57 & 57 & 57 & 57 & 57 & 57 & 57 & 57 & 57 & 57 & 57 & 57 \\
\hline \multirow[t]{4}{*}{01169600} & Streamflow & .80 & .96 & 1.29 & 1.80 & 2.32 & 2.92 & 3.62 & 4.48 & 6.41 & 9.07 & 2.41 & .70 & 1.20 \\
\hline & Variance & .0012 & .00082 & .00041 & .00025 & .00034 & .00058 & .00092 & .0014 & .00244 & .00376 & .00039 & .00179 & .00063 \\
\hline & Standard error & 8.0 & 6.6 & 4.7 & 3.6 & 4.2 & 5.5 & 7.0 & 8.6 & 11.4 & 14.2 & 4.5 & 9.8 & 5.8 \\
\hline & Years & 44.5 & 46.8 & 52.3 & 60.5 & 56.6 & 45.4 & 35.6 & 27.5 & 17.9 & 12.7 & 39.7 & 8.8 & 13.7 \\
\hline \multirow[t]{4}{*}{01169800} & Streamflow & .22 & .29 & .44 & .69 & .96 & 1.32 & 1.78 & 2.42 & 4.12 & .. & 1.02 & .19 & .39 \\
\hline & Variance & .00155 & .00108 & .00059 & .00047 & .00066 & .00103 & .00156 & .00226 & .00389 & -- & .00075 & .0026 & .00103 \\
\hline & Standard error & 9.1 & 7.6 & 5.6 & 5.0 & 5.9 & 7.4 & 9.1 & 11.0 & 14.4 & -- & 6.3 & 11.8 & 7.4 \\
\hline & Years & 40.7 & 42 & 45.5 & 49.2 & 47.1 & 41.2 & 34.2 & 27.9 & 18.7 & -- & 35.9 & 11.2 & 16.3 \\
\hline \multirow[t]{4}{*}{01169801} & Streamflow & 2.41 & 2.75 & 3.44 & 4.24 & 4.95 & 5.79 & 6.69 & 7.77 & 9.98 & 12.8 & 5.07 & 2.17 & 3.10 \\
\hline & Variance & .00017 & .00011 & .00007 & .00008 & .00013 & .0002 & .0003 & .00043 & .00069 & .00103 & .00016 & .00051 & .00021 \\
\hline & Standard error & 3.0 & 2.4 & 1.9 & 2.1 & 2.6 & 3.3 & 4.0 & 4.8 & 6.1 & 7.4 & 2.9 & 5.2 & 3.3 \\
\hline & Years & 33.6 & 34.1 & 36.1 & 39.4 & 37.2 & 32.1 & 27.4 & 23.6 & 18.3 & 15 & 28.4 & 14.5 & 17.9 \\
\hline \multirow[t]{4}{*}{01169900} & Streanflow & 3.70 & 4.32 & 5.70 & 7.40 & 9.10 & 11.0 & 13.0 & 16.0 & 22.0 & 30.0 & 9.60 & 3.32 & 5.37 \\
\hline & Variance & .00007 & .00006 & .00004 & .00003 & .00003 & .00003 & .00002 & .00002 & .00002 & .00002 & .00014 & .00165 & .00091 \\
\hline & Standard error & 1.9 & 1.8 & 1.5 & 1.3 & 1.2 & 1.2 & 1.1 & 1.1 & 1.0 & 1.0 & 2.7 & 9.4 & 6.9 \\
\hline & Years & 30 & 30 & 30 & 30 & 30 & 30 & 30 & 30 & 30 & 30 & 30 & 30 & 30 \\
\hline \multirow[t]{4}{*}{01170100} & Streamflow & -- & 7.10 & 8.80 & 12.0 & 14.6 & 17.6 & 21.0 & 26.0 & 36.0 & 49.0 & 15.0 & 4.81 & 7.61 \\
\hline & Variance & $\cdots$ & .00007 & .00005 & .00004 & .00003 & .00003 & .00003 & .00002 & .00002 & .00002 & .00013 & .00179 & .00098 \\
\hline & Standard error & - & 1.9 & 1.6 & 1.4 & 1.3 & 1.2 & 1.2 & 1.1 & 1.1 & 1.1 & 2.6 & 9.8 & 7.2 \\
\hline & Years & -- & 29 & 29 & 29 & 29 & 29 & 29 & 29 & 29 & 29 & 29 & 29 & 29 \\
\hline \multirow[t]{4}{*}{01170575} & Streamflow & 3.80 & 4.20 & 5.33 & 6.50 & 7.48 & 8.60 & 9.79 & 11.0 & 13.7 & -- & 7.73 & 3.48 & 5.05 \\
\hline & Variance & .00253 & .00181 & .00088 & .00066 & .00082 & .00118 & .00172 & .00235 & .00399 & - & .00088 & .00323 & .00105 \\
\hline & Standard error & 11.6 & 9.8 & 6.8 & 5.9 & 6.6 & 7.9 & 9.6 & 11.2 & 14.6 & -- & 6.8 & 13.1 & 7.5 \\
\hline & Years & 22.7 & 24.9 & 31.4 & 29.2 & 23.2 & 16.3 & 11 & 7.7 & 4.2 & -- & 13.5 & 2.3 & 3.8 \\
\hline
\end{tabular}


Table 9. Streamflow statistics, variances, standard errors, and years of record for stations included in the regression analyses; streamflow statistics are computed from daily records for streamgaging stations and estimated for low-flow partial-record stations; equivalent years of record for low-flow partial-record stations are

computed from equation 14-Continued

\begin{tabular}{|c|c|c|c|c|c|c|c|c|c|c|c|c|c|c|}
\hline \multirow{2}{*}{$\begin{array}{c}\text { Station } \\
\text { No. }\end{array}$} & \multirow{2}{*}{ Statistic } & \multicolumn{10}{|c|}{ Flow-duration percentile } & \multirow{2}{*}{$\begin{array}{l}\text { August } \\
\text { median }\end{array}$} & \multirow{2}{*}{$\begin{array}{l}\text { 7-Day, } \\
\text { 10-year } \\
\text { low flow }\end{array}$} & \multirow{2}{*}{$\begin{array}{l}\text { 7-Day, } \\
\text { 2-year } \\
\text { low flow }\end{array}$} \\
\hline & & 99 & 98 & 95 & 90 & 85 & 80 & 75 & 70 & 60 & 50 & & & \\
\hline \multirow[t]{4}{*}{01171500} & Streamflow & 6.70 & 7.80 & 10.0 & 14.0 & 17.0 & 21.0 & 25.0 & 29.0 & 40.0 & 55.0 & 18.0 & 6.31 & 10.0 \\
\hline & Variance & .00004 & .00003 & .00002 & .00002 & .00002 & .00001 & .00001 & .00001 & .00001 & .00001 & .00007 & .00087 & .00048 \\
\hline & Standard error & 1.4 & 1.3 & 1.1 & 1.0 & .9 & .9 & .8 & .8 & .7 & .7 & 2.0 & 6.8 & 5.0 \\
\hline & Years & 57 & 57 & 57 & 57 & 57 & 57 & 57 & 57 & 57 & 57 & 57 & 57 & 57 \\
\hline \multirow[t]{4}{*}{01171800} & Streamflow & .55 & .63 & .79 & 1.10 & 1.40 & 1.70 & 2.00 & 2.30 & 3.60 & 4.80 & 1.50 & .46 & .89 \\
\hline & Variance & .00019 & .00016 & .00012 & .00010 & .00008 & .00007 & .00006 & .00006 & .00005 & .00005 & .00039 & .00883 & .00485 \\
\hline & Standard erró & 3.2 & 2.9 & 2.6 & 2.3 & 2.1 & 1.9 & 1.8 & 1.8 & 1.7 & 1.7 & 4.5 & 21.9 & 16.1 \\
\hline & Years & 11 & 11 & 11 & 11 & 11 & 11 & 11 & 11 & 11 & 11 & 11 & 11 & 11 \\
\hline \multirow[t]{4}{*}{01171947} & Streamflow & 1.61 & 1.97 & 3.06 & 4.62 & 6.02 & 7.42 & 8.75 & 10.5 & 14.7 & 20.4 & 6.96 & 1.49 & 3.03 \\
\hline & Variance & .00386 & .00301 & .00169 & .00102 & .00088 & .0009 & .00101 & .00121 & .00188 & .00282 & .00086 & .00477 & .00195 \\
\hline & Standard error & 14.4 & 12.7 & 9.5 & 7.4 & 6.8 & 6.9 & 7.3 & 8.0 & 10.0 & 12.3 & 6.8 & 16.0 & 10.2 \\
\hline & Years & 34.2 & 35.7 & 39.8 & 42.7 & 44.4 & 45.4 & 44.1 & 40.5 & 31.9 & 24.4 & 34.1 & 8.3 & 11 \\
\hline \multirow[t]{4}{*}{01171970} & Streamflow & .85 & 1.11 & 1.91 & 3.38 & 5.12 & 7.17 & 9.62 & - & .. & -. & 5.65 & -- & -- \\
\hline & Variance & .00851 & .00637 & .00333 & .00189 & .0021 & .00291 & .00402 & -- & -- & -- & .00226 & - & -- \\
\hline & Standard error & 21.5 & 18.5 & 13.3 & 10.0 & 10.6 & 12.5 & 14.7 & -- & -- & -- & 11.0 & -- & .. \\
\hline & Years & 24.1 & 26.7 & 34.1 & 41.6 & 34.3 & 25.4 & 18.9 & -- & -- & -- & 20.9 & -- & - \\
\hline \multirow[t]{4}{*}{01172810} & Streamflow & 1.38 & 1.55 & 2.05 & 2.64 & 3.18 & 3.69 & 4.19 & 4.70 & -- & -- & 3.36 & 1.29 & 2.02 \\
\hline & Variance & .0047 & .00352 & .00176 & .00108 & .00113 & .00149 & .00202 & .00268 & -. &.- & .00122 & .0055 & .00191 \\
\hline & Standard error & 15.9 & 13.7 & 9.7 & 7.6 & 7.8 & 8.9 & 10.4 & 12.0 & -- & -- & 8.1 & 17.2 & 10.1 \\
\hline & Years & 13.4 & 14.6 & 21.7 & 25.8 & 20 & 13.9 & 9.8 & 7.1 & -- & -- & 11.1 & 1.7 & .3 .1 \\
\hline \multirow[t]{4}{*}{01173260} & Streamflow & .. & -- & .040 & .15 & .34 & .56 & .88 & 1.40 & 2.60 & 3.60 & .26 & $\cdot-$ & -- \\
\hline & Variance & -- & - & .00058 & .00045 & .00038 & .00033 & .00030 & .00028 & .00025 & .00025 & .00288 & -- & -- \\
\hline & Standard error & -- & -- & 5.6 & 4.9 & 4.5 & 4.2 & 4.0 & 3.9 & 3.7 & 3.6 & 12.4 & -- & - \\
\hline & Years & -- & -- & 9 & 9 & 9 & 9 & 9 & 9 & 9 & 9 & 9 & -- & -. \\
\hline \multirow[t]{4}{*}{01173420} & Streamflow & 2.37 & 2.68 & 3.69 & 4.96 & 6.08 & 7.40 & 8.82 & 10.2 & 13.5 & 17.1 & 6.47 & 2.17 & 3.56 \\
\hline & Variance & .00319 & .00251 & .00136 & .00075 & .00055 & .0005 & .00061 & .00079 & .00133 & .00199 & .00054 & .00398 & .00165 \\
\hline & Standard error & 13.1 & 11.6 & 8.5 & 6.3 & 5.4 & 5.2 & 5.7 & 6.5 & 8.4 & 10.3 & 5.4 & 14.6 & 9.4 \\
\hline & Years & 22 & 22.8 & 27.2 & 31.7 & 34.8 & 36.9 & 33.7 & 28.9 & 20 & 14.4 & 29.5 & 4.3 & 6.1 \\
\hline \multirow[t]{4}{*}{01173450} & Streamflow & .22 & .27 & .44 & .71 & 1.03 & 1.37 & 1.78 & 2.22 & 3.58 & 5.33 & 1.09 & .20 & .42 \\
\hline & Variance & .00133 & .00105 & .00062 & .00044 & .00048 & .0006 & .00077 & .00097 & .00159 & .0023 & .00053 & .00239 & .00111 \\
\hline & Standard error & 8.4 & 7.5 & 5.7 & 4.8 & 5.0 & 5.6 & 6.4 & 7.2 & 9.2 & 11.1 & 5.3 & 11.3 & 7.7 \\
\hline & Years & 37 & 37.9 & 39.7 & 41 & 40.4 & 37.9 & 34.7 & 31.4 & 24.2 & 19 & 32.1 & 15.3 & 17.7 \\
\hline
\end{tabular}


Table 9. Streamflow statistics, variances, standard errors, and years of record for stations included in the regression analyses; streamflow statistics are computed from daily records for streamgaging stations and estimated for low-flow partial-record stations; equivalent years of record for low-flow partial-record stations are computed from equation 14-Continued

\begin{tabular}{|c|c|c|c|c|c|c|c|c|c|c|c|c|c|c|}
\hline \multirow{2}{*}{$\begin{array}{c}\text { Station } \\
\text { No. }\end{array}$} & \multirow{2}{*}{ Statistic } & \multicolumn{10}{|c|}{ Flow-duration percentile } & \multirow{2}{*}{$\begin{array}{l}\text { August } \\
\text { median }\end{array}$} & \multirow{2}{*}{$\begin{array}{l}\text { 7-Day, } \\
\text { 10-year } \\
\text { low flow }\end{array}$} & \multirow{2}{*}{$\begin{array}{l}\text { 7-Day, } \\
\text { 2-year } \\
\text { low flow }\end{array}$} \\
\hline & & 99 & 98 & 95 & 90 & 85 & 80 & 75 & 70 & 60 & 50 & & & \\
\hline \multirow[t]{4}{*}{01174000} & Streamflow & 0.020 & 0.050 & 0.14 & 0.31 & 0.56 & 0.81 & 1.14 & 1.55 & 2.50 & 3.60 & 0.50 & -- & -- \\
\hline & Variance & .00014 & .00011 & .00009 & .00007 & .00006 & .00005 & .00004 & .00004 & .00004 & .00004 & .00052 & -. & -- \\
\hline & Standard error & 2.7 & 2.5 & 2.1 & 1.9 & 1.7 & 1.6 & 1.5 & 1.5 & 1.4 & 1.4 & 5.3 & -- & -- \\
\hline & Years & 34 & 34 & 34 & 34 & 34 & 34 & 34 & 34 & 34 & 34 & 34 & - & - \\
\hline \multirow[t]{4}{*}{01174050} & Streamflow & .16 & .19 & .27 & .50 & .91 & 1.21 & 1.57 & 1.91 & 2.98 & 4.44 & 1.85 & - & -- \\
\hline & Variance & .00170 & .00143 & .00108 & .00084 & .00071 & .00062 & .00056 & .00052 & .00047 & .00046 & .00369 & -- & -- \\
\hline & Standard error & 9.5 & 8.7 & 7.6 & 6.7 & 6.1 & 5.8 & 5.5 & 5.3 & 5.0 & 4.9 & 14.0 & - & - \\
\hline & Years & 2 & 2 & 2 & 2 & 2 & 2 & 2 & 2 & 2 & 2 & 2 & $\cdots$ & $\cdots$ \\
\hline \multirow[t]{4}{*}{01174565} & Streanflow & .90 & 1.00 & 1.40 & 2.09 & 2.94 & 4.10 & 5.49 & 6.15 & 8.12 & 11.9 & 3.24 & - & -- \\
\hline & Variance & .00010 & .00008 & .00006 & .00005 & .00004 & .00004 & .00003 & .00003 & .00040 & .000026 & .00028 & -- & -- \\
\hline & Standard error & 2.3 & 2.1 & 1.8 & 1.6 & 1.5 & 1.4 & 1.3 & 1.3 & 4.6 & 1.2 & 3.8 & - & - \\
\hline & Years & 2 & 2 & 2 & 2 & 2 & 2 & 2 & 2 & 2 & 2 & 2 & -- & -- \\
\hline \multirow[t]{4}{*}{01174900} & Streamflow & .11 & .13 & .21 & .34 & .52 & .72 & 1.00 & 1.30 & 2.10 & 3.00 & .55 & 0.092 & 0.18 \\
\hline & Variance & .00009 & .00008 & .00006 & .00005 & .00004 & .00003 & .00003 & .00003 & .00003 & .00003 & .00026 & .00523 & .00287 \\
\hline & Standard error & 2.2 & 2.0 & 1.8 & 1.6 & 1.4 & 1.3 & 1.3 & 1.2 & 1.2 & 1.2 & 3.7 & 16.8 & 12.4 \\
\hline & Years & 35 & 35 & 35 & 35 & 35 & 35 & 35 & 35 & 35 & 35 & 35 & 35 & 35 \\
\hline \multirow[t]{4}{*}{01175670} & Streamflow & .28 & .35 & .61 & 1.10 & 1.80 & 2.60 & 3.40 & 4.30 & 6.70 & 9.40 & 1.90 & .23 & .56 \\
\hline & Variance & .00009 & .00008 & .00006 & .00005 & .00004 & .00003 & .00003 & .00003 & .00003 & .00003 & .00026 & .00523 & .00287 \\
\hline & Standard error & 2.2 & 2.0 & 1.8 & 1.6 & 1.4 & 1.3 & 1.3 & 1.2 & 1.2 & 1.2 & 3.7 & 16.8 & 12.4 \\
\hline & Years & 35 & 35 & 35 & 35 & 35 & 35 & 35 & 35 & 35 & 35 & 35 & 35 & 35 \\
\hline \multirow[t]{4}{*}{01175710} & Streamflow & .32 & .42 & .82 & 1.52 & 2.18 & 3.10 & 4.14 & 5.34 & 8.49 & - & 2.52 & .30 & .83 \\
\hline & Variance & .0092 & .00729 & .00431 & .00274 & .0024 & .00253 & .00286 & .00319 & .00394 & - & .00239 & .01102 & .00527 \\
\hline & Standard error & 22.4 & 19.9 & 15.2 & 12.1 & 11.3 & 11.6 & 12.4 & 13.1 & 14.5 & -- & 11.3 & 24.5 & 16.8 \\
\hline & Years & 32.1 & 32.3 & 34.9 & 36.3 & 33.8 & 32.3 & 30.5 & 29 & 26.3 & -- & 25.5 & 8.4 & 8.8 \\
\hline \multirow[t]{4}{*}{01175850} & Streamflow & 1.05 & 1.24 & 1.83 & 2.70 & 3.69 & 4.72 & 5.78 & 6.92 & 9.80 & 13.2 & 3.96 & .97 & 1.81 \\
\hline & Variance & .00107 & .00086 & .0005 & .00031 & .0003 & .00036 & .00047 & .0006 & .00095 & .00136 & .00034 & .00174 & .00081 \\
\hline & Standard error & 7.5 & 6.8 & 5.2 & 4.1 & 4.0 & 4.4 & 5.0 & 5.6 & 7.1 & 8.5 & 4.2 & 9.6 & 6.6 \\
\hline & Years & 36.1 & 37 & 39 & 40.2 & 40.2 & 39.1 & 36.5 & 32.9 & 25.7 & 20.6 & 33.1 & 12.4 & 15 \\
\hline \multirow[t]{4}{*}{01175890} & Streamflow & .12 & .16 & .30 & .48 & .66 & .86 & 1.08 & 1.35 & 2.06 & 3.03 & .74 & .10 & .29 \\
\hline & Variance & .00383 & .00288 & .00153 & .00088 & .00066 & .00061 & .00067 & .00082 & .00134 & .00207 & .00063 & .00493 & .00194 \\
\hline & Standard error & 14.3 & 12.4 & 9.0 & 6.8 & 5.9 & 5.7 & 6.0 & 6.6 & 8.4 & 10.5 & 5.8 & 16.3 & 10.2 \\
\hline & Years & 37.9 & 41.4 & 49.3 & 52.1 & 50.2 & 50.7 & 50.9 & 48.9 & 40.4 & 31.3 & 43.9 & 10.3 & 16.4 \\
\hline
\end{tabular}


Table 9. Streamflow statistics, variances, standard errors, and years of record for stations included in the regression analyses; streamflow statistics are computed from daily records for streamgaging stations and estimated for low-flow partial-record stations; equivalent years of record for low-flow partial-record stations are computed from equation 14-Continued

\begin{tabular}{|c|c|c|c|c|c|c|c|c|c|c|c|c|c|c|}
\hline \multirow{2}{*}{$\begin{array}{c}\text { Station } \\
\text { No. }\end{array}$} & \multirow{2}{*}{ Statistic } & \multicolumn{10}{|c|}{ Flow-duration percentile } & \multirow{2}{*}{$\begin{array}{l}\text { August } \\
\text { median }\end{array}$} & \multirow{2}{*}{$\begin{array}{l}\text { 7-Day, } \\
\text { 10-year } \\
\text { low flow }\end{array}$} & \multirow{2}{*}{$\begin{array}{l}\text { 7-Day, } \\
\text { 2-year } \\
\text { low flow }\end{array}$} \\
\hline & & 99 & 98 & 95 & 90 & 85 & 80 & 75 & 70 & 60 & 50 & & & \\
\hline \multirow[t]{4}{*}{01176000} & Streamflow & 16.0 & 20.0 & 30.0 & 42.0 & 52.0 & 65.0 & 78.0 & 93.0 & 126 & 168 & 65.0 & 15.8 & 32.8 \\
\hline & Variance & .00002 & .00002 & .00001 & .00001 & .00001 & .00001 & .00001 & .00001 & .00001 & .00001 & .00005 & .00124 & .00068 \\
\hline & Standard error & 1.1 & 1.0 & .9 & .8 & .7 & .7 & .6 & .6 & 6 & .6 & 1.7 & 8.1 & 6.0 \\
\hline & Years & 83 & 83 & 83 & 83 & 83 & 83 & 83 & 83 & 83 & 83 & 83 & 83 & 83 \\
\hline \multirow[t]{4}{*}{01176100} & Streamflow & - & -- & .82 & 1.47 & 1.97 & $\therefore$ & -- & -- & -- & .. & -- & .11 & .91 \\
\hline & Variance & -- & -- & .00542 & .00402 & .00409 & -- & -. & -. & -- & -- & -- & .01378 & .00608 \\
\hline & Standard error & -- & -- & 17.1 & 14.7 & 14.8 & .. & -- & -- & -- & -- & - & 27.5 & 18.1 \\
\hline & Years & - & - & 60.2 & 61.1 & 57.1 & -- & -- & -- & -- & -- & -- & 11.8 & 16 \\
\hline \multirow[t]{4}{*}{01176200} & Streamflow & .74 & .89 & 1.18 & 1.58 & 1.94 & 2.30 & 2.59 & 2.95 & 3.81 & 4.97 & 2.08 & .69 & 1.22 \\
\hline & Variance & .00105 & .00078 & .00048 & .00036 & .00037 & .00045 & .00055 & .00068 & .00103 & .00153 & .00041 & .0015 & .00064 \\
\hline & Standard error & 7.5 & 6.4 & 5.0 & 4.4 & 4.4 & 4.9 & 5.4 & 6.0 & 7.4 & 9.0 & 4.7 & 8.9 & 5.8 \\
\hline & Years & 40.3 & 41.7 & 45 & 45.2 & 42.1 & 37 & 31.5 & 26.9 & 20.2 & 15.6 & 30.9 & 10.4 & 14 \\
\hline \multirow[t]{4}{*}{01176300} & Streamflow & -- & -- & -- & 3.48 & 3.90 & 4.30 & 4.61 & 4.97 & 5.79 & 6.74 & 4.09 & -- & .. \\
\hline & Variance & -- & -- & $\cdots$ & .00015 & .00018 & .00024 & .0003 & .0004 & .00068 & .00106 & .00022 & .. & - \\
\hline & Standard error & -. & -- & -- & 2.8 & 3.1 & 3.6 & 4.0 & 4.6 & 6.0 & 7.5 & 3.4 & -- & - \\
\hline & Years & -- & -- & -- & 53.1 & 48 & 40.3 & 33.6 & 27.4 & 17.7 & 11.8 & 27.6 & -- & - \\
\hline \multirow[t]{4}{*}{01176415} & Streamflow & 3.31 & 3.58 & 4.26 & 5.02 & 5.78 & 6.48 & 6.93 & 7.61 & 9.08 & 10.5 & 6.05 & 3.11 & 4.17 \\
\hline & Variance & .00072 & .00055 & .00029 & .00015 & .00012 & .00016 & .00021 & .0003 & .00057 & .0009 & .00014 & .00100 & .00038 \\
\hline & Standard error & 6.2 & 5.4 & 3.9 & 2.8 & 2.5 & 2.9 & 3.3 & 4.0 & 5.5 & 6.9 & 2.7 & 7.3 & 4.5 \\
\hline & Years & 25.2 & 26.9 & 31.4 & 34.3 & 32.6 & 28.7 & 24.9 & 21 & 14.1 & 9.5 & 27.2 & 4.7 & 7.9 \\
\hline \multirow[t]{4}{*}{01176780} & Streamflow & 1.75 & 2.10 & 3.00 & 4.20 & 5.41 & 6.76 & 7.70 & 9.16 & 13.1 & -- & 6.42 & 1.68 & 3.18 \\
\hline & Variance & .0066 & .00497 & .00274 & .00138 & .00091 & .00088 & .00105 & .00137 & .00265 & -- & .00091 & .00764 & .00271 \\
\hline & Standard error & 18.9 & 16.3 & 12.1 & 8.6 & 7.0 & 6.8 & 7.5 & 8.5 & 11.9 & -- & 7.0 & 20.3 & 12.0 \\
\hline & Years & 17 & 18.5 & 23.2 & 29.1 & 31.5 & 29.8 & 26 & 22.1 & 14.2 & -- & 21.1 & 2.8 & 5.1 \\
\hline \multirow[t]{4}{*}{01177360} & Streamflow & 2.74 & 2.97 & 3.61 & 4.32 & 4.95 & 5.58 & 5.91 & 6.50 & 7.79 & 9.25 & 5.57 & -- & .. \\
\hline & Variance & .00272 & .00207 & .00112 & .00057 & .00038 & .00036 & .00041 & .00055 & .00103 & .00176 & .00041 & -- & - \\
\hline & Standard error & 12.1 & 10.5 & 7.7 & 5.5 & 4.5 & 4.4 & 4.7 & 5.4 & 7.4 & 9.7 & 4.7 & -- & -- \\
\hline & Years & 12.1 & 13.3 & 17 & 22.3 & 26.1 & 27.2 & 24.2 & 20.3 & 12.6 & 7 & 19 & -- & -- \\
\hline \multirow[t]{4}{*}{01178200} & Streamflow & .62 & .79 & 1.16 & 1.82 & 2.43 & 3.21 & 4.11 & 5.20 & 8.18 & 12.6 & 2.55 & .54 & 1.11 \\
\hline & Variance & .00089 & .00064 & .00043 & .00041 & .00054 & .00077 & .00107 & .00144 & .00234 & .00345 & .0006 & .00166 & .0007 \\
\hline & Standard error & 6.9 & 5.8 & 4.8 & 4.7 & 5.4 & 6.4 & 7.5 & 8.8 & 11.2 & 13.6 & 5.6 & 9.4 & 6.1 \\
\hline & Years & 58.8 & 61 & 59.3 & 55.3 & 52.1 & 47.6 & 42.6 & 37.9 & 29.5 & 23.3 & 40.6 & 18.8 & 23.6 \\
\hline
\end{tabular}


Table 9. Streamflow statistics, variances, standard errors, and years of record for stations included in the regression analyses; streamflow statistics are computed from daily records for streamgaging stations and estimated for low-flow partial-record stations; equivalent years of record for low-flow partial-record stations are computed from equation 14-Continued

\begin{tabular}{|c|c|c|c|c|c|c|c|c|c|c|c|c|c|c|}
\hline \multirow{2}{*}{$\begin{array}{c}\text { Station } \\
\text { No. }\end{array}$} & \multirow{2}{*}{ Statistic } & \multicolumn{10}{|c|}{ Flow-duration percentile } & \multirow{2}{*}{$\begin{array}{l}\text { August } \\
\text { median }\end{array}$} & \multirow{2}{*}{$\begin{array}{l}\text { 7-Day, } \\
\text { 10-year } \\
\text { low flow }\end{array}$} & \multirow{2}{*}{$\begin{array}{l}\text { 7-Day, } \\
\text { 2-year } \\
\text { low flow }\end{array}$} \\
\hline & & 99 & 98 & 95 & 90 & 85 & 80 & 75 & 70 & 60 & 50 & & & \\
\hline \multirow{4}{*}{01178300} & Streamflow & 1.51 & 1.90 & 2.87 & 4.37 & 5.68 & 7.36 & 9.33 & 11.6 & -- & -- & 5.91 & 1.32 & 2.71 \\
\hline & Variance & .00194 & .00135 & .00086 & .00081 & .00114 & .00172 & .00246 & .00334 & -- & -- & .00126 & .00309 & .00115 \\
\hline & Standard error & 10.2 & 8.5 & 6.8 & 6.6 & 7.8 & 9.6 & 11.5 & 13.4 & -- & -- & 8.2 & 12.9 & 7.8 \\
\hline & Years & 56.5 & 60 & 58.3 & 52.2 & 46.4 & 38.6 & 31.3 & 25.8 & -- & -- & 30.8 & 10.2 & 15.6 \\
\hline \multirow[t]{4}{*}{01178490} & Streamflow & .73 & 1.06 & 1.99 & -- & -- & .. & -- & -- & -- & -- & 4.77 & .59 & 1.67 \\
\hline & Variance & .00796 & .00533 & .00253 & .. & -- & -- & -- & -- & -. & .. & .0017 & .01096 & .00386 \\
\hline & Standard error & 20.8 & 16.9 & 11.6 & -- & -- & - & -- & - & -- & -- & 9.5 & 24.5 & 14.4 \\
\hline & Years & 29.6 & 31.3 & 35.3 & -- & -- & - & -- & - & -- & -- & 30 & 5.5 & 9 \\
\hline \multirow[t]{4}{*}{01179900} & Streanflow & -- & -- & .21 & .55 & 1.04 & 1.74 & 2.97 & - & .. & -- & 1.04 & -- & -- \\
\hline & Variance & -. & -- & .00422 & .00215 & .00168 & .00184 & .00248 & $\cdots$ & -- & $\therefore-$ & .00205 & - & -- \\
\hline & Standard error & -- & -- & 15.0 & 10.7 & 9.5 & 9.9 & 11.5 & - & -- & -- & 10.5 & -- &.- \\
\hline & Years & $-\cdot$ & - & 52.5 & 55.4 & 56.5 & 55.9 & 54.1 & -. & - & -- & 51.4 & -- & -- \\
\hline \multirow[t]{4}{*}{01180000} & Streamflow & .070 & .080 & .11 & .16 & .22 & .28 & .38 & .53 & 0.86 & 1.20 & .21 & .058 & .11 \\
\hline & Variance & .00013 & .00011 & .00008 & .00006 & .00005 & .00005 & .00004 & .00004 & .00004 & .00003 & .00022 & .00306 & .00168 \\
\hline & Standard error & 2.6 & 2.4 & 2.1 & 1.8 & 1.7 & 1.6 & 1.5 & 1.4 & 1.4 & 1.3 & 3.4 & 12.8 & 9.5 \\
\hline & Years & 28 & 28 & 28 & 28 & 28 & 28 & 28 & 28 & 28 & 28 & 28 & 28 & 28 \\
\hline \multirow[t]{4}{*}{01180500} & Streamflow & 2.90 & .. & 5.30 & 8.20 & 11.0 & 15.0 & 19.0 & 24.0 & 36.0 & 50.0 & 11.2 & 1.40 & 5.33 \\
\hline & Variance & .00004 & -- & .00003 & .00002 & .00002 & .00002 & .00001 & .00001 & .00001 & .00001 & .00009 & .00326 & .00179 \\
\hline & Standard error & 1.5 & -. & 1.2 & 1.0 & 1.0 & .9 & .9 & .8 & .8 & .8 & 2.1 & 13.2 & 9.8 \\
\hline & Years & 79 & -- & 79 & 79 & 79 & 79 & 79 & 79 & 79 & 79 & 79 & 79 & 79 \\
\hline \multirow[t]{4}{*}{01180650} & Streamflow & .30 & .37 & .55 & .86 & 1.28 & -- & -. & $\ldots$ & -- & -- & 1.31 & .24 & .55 \\
\hline & Variance & .00922 & .00646 & .00338 & .00193 & .00272 & .- & -- & - & -- & -- & .0029 & .01298 & .0039 \\
\hline & Standard error & 22.4 & 18.7 & 13.4 & 10.1 & 12.1 & - & - & $\cdots$ & -- & -- & 12.4 & 26.7 & 14.5 \\
\hline & Years & 26.4 & 30.8 & 41.3 & 51.7 & 41.7 & - & -- & -- & -- & -- & 29.3 & 3.1 & 5.6 \\
\hline \multirow[t]{4}{*}{01180800} & Streamfiow & .26 & .30 & .40 & .54 & .74 & 1.00 & 1.30 & 1.60 & 2.50 & 3.40 & .80 & .21 & .34 \\
\hline & Variance & .00021 & .00018 & .00013 & .00010 & .00009 & .00008 & .00007 & .00006 & .00006 & .00006 & .00051 & .00329 & .00181 \\
\hline & Standard enror & 3.3 & 3.0 & 2.7 & 2.3 & 2.1 & 2.0 & 1.9 & 1.8 & 1.8 & 1.7 & 5.2 & 13.3 & 9.8 \\
\hline & Years & 14 & 14 & 14 & 14 & 14 & 14 & 14 & 14 & 14 & 14 & 14 & 14 & 14 \\
\hline \multirow[t]{4}{*}{01181000} & Strearnflow & 7.10 & 8.90 & 12.0 & 18.0 & 24.0 & 30.0 & 38.0 & 46.0 & 70.0 & 96.0 & 23.0 & 5.79 & 11.0 \\
\hline & Variance & .00005 & .00004 & .00003 & .00002 & .00002 & .00002 & .00002 & .00001 & .00001 & .00001 & .00010 & .00155 & .00085 \\
\hline & Standard error & 1.6 & 1.4 & 1.3 & 1.1 & 1.0 & 1.0 & .9 & .9 & .8 & .8 & 2.3 & 9.1 & 6.7 \\
\hline & Years & 60 & 60 & 60 & 60 & 60 & 60 & 60 & 60 & 60 & 60 & 60 & 60 & 60 \\
\hline
\end{tabular}


Table 9. Streamflow statistics, variances, standard errors, and years of record for stations included in the regression analyses; streamflow statistics are computed from daily records for streamgaging stations and estimated for low-flow partial-record stations; equivalent years of record for low-flow partial-record stations are computed from equation 14-Continued

\begin{tabular}{|c|c|c|c|c|c|c|c|c|c|c|c|c|c|c|}
\hline \multirow{2}{*}{$\begin{array}{c}\text { Station } \\
\text { No. }\end{array}$} & \multirow{2}{*}{ Statistic } & \multicolumn{10}{|c|}{ Flow-duration percentile } & \multirow{2}{*}{$\begin{array}{l}\text { August } \\
\text { median }\end{array}$} & \multirow{2}{*}{$\begin{array}{l}\text { 7-Day, } \\
\text { 10-year } \\
\text { low flow }\end{array}$} & \multirow{2}{*}{$\begin{array}{l}\text { 7-Day, } \\
\text { 2-year } \\
\text { low flow }\end{array}$} \\
\hline & & 99 & 98 & 95 & 90 & 85 & 80 & 75 & 70 & 60 & 50 & & & \\
\hline \multirow[t]{4}{*}{01183210} & Streamflow & 2.95 & 4.43 & 7.26 & 8.77 & 10.5 & 11.7 & 12.2 & 13.3 & 15.4 & 16.8 & 11.9 & 1.94 & 7.44 \\
\hline & Variance & .00249 & .00175 & .00096 & .00065 & .00051 & .00054 & .00064 & .00085 & .00169 & .00313 & .00058 & .0035 & .00117 \\
\hline & Standard error & 11.5 & 9.7 & 7.1 & 5.9 & 5.2 & 5.4 & 5.8 & 6.7 & 9.5 & 12.9 & 5.5 & 13.7 & 7.9 \\
\hline & Years & 45.3 & 48.3 & 54.1 & 51.5 & 46.8 & 41.2 & 35.5 & 31.4 & 23.7 & 16.9 & 36.4 & 8.4 & 14.6 \\
\hline \multirow[t]{4}{*}{01184200} & Streamflow & .48 & .57 & .78 & 1.12 & 1.47 & 1.83 & 2.17 & 2.55 & 3.52 & 4.70 & 1.56 & .43 & .78 \\
\hline & Variance & .00076 & .00064 & .0005 & .00043 & .00044 & .0005 & .00057 & .00065 & .00088 & .00116 & .00047 & .00113 & .00067 \\
\hline & Standard error & 6.4 & 5.8 & 5.2 & 4.8 & 4.8 & 5.2 & 5.5 & 5.9 & 6.8 & 7.9 & 5.0 & 7.8 & 6.0 \\
\hline & Years & 38.8 & 38.7 & 37.9 & 36.5 & 34.3 & 31.5 & 28.6 & 26 & 21.1 & 17.6 & 25.4 & 10.9 & 10.4 \\
\hline \multirow[t]{4}{*}{01184277} & Streamflow & 1.41 & 2.25 & 4.32 & 6.36 & 7.82 & 8.90 & 9.46 & 10.2 & 11.5 & -- & 8.44 & -. & 4.21 \\
\hline & Variance & .00239 & .00184 & .00094 & .00055 & .00058 & .00085 & .00117 & .00165 & .00294 & 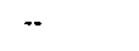 & .00075 & $\cdot-$ & .00128 \\
\hline & Standard error & 11.3 & 9.9 & 7.1 & 5.4 & 5.5 & 6.7 & 7.9 & 9.4 & 12.5 & -- & 6.3 & -- & 8.3 \\
\hline & Years & 31.3 & 32.3 & 36.9 & 39.3 & 36.9 & 31.6 & 26.2 & 21.5 & 14.5 & -- & 27.3 & -- & 11.8 \\
\hline \multirow[t]{4}{*}{01184855} & Strearnflow & 3.13 & 4.03 & 5.94 & 8.50 & 11.5 & 14.9 & 18.6 & 22.9 & -- & -- & 12.0 & 2.70 & 5.81 \\
\hline & Variance & .00349 & .00249 & .00148 & .00106 & .00113 & .00148 & .00199 & .00264 & -- & -- & .00119 & .00456 & .00174 \\
\hline & Standard error & 13.7 & 11.5 & 8.9 & 7.5 & 7.8 & 8.9 & 10.3 & 11.9 & - & -- & 8.0 & 15.6 & 9.6 \\
\hline & Years & 32.6 & 35.1 & 39 & 39.9 & 36.5 & 30.5 & 24.2 & 19.2 & -- & -- & 23.7 & 4.8 & 7.3 \\
\hline \multirow[t]{4}{*}{01185490} & Strearnflow & 2.17 & 2.99 & -- & -- & -- & $\cdots$ & -- & -. & -- & -. & 10.3 & 1.75 & 4.47 \\
\hline & Variance & .00643 & .00432 & -- & -- & $\cdots$ & -- & -- & -- & - & -- & .00315 & .00847 & .00317 \\
\hline & Standard error & 18.6 & 15.2 & -- & -- & -- & $\cdots$ & -- & - & -- & -- & 13.0 & 21.4 & 13.0 \\
\hline & Years & 45.1 & 49.8 & $\sim$ & -- & -- & $\cdots$ & -- & $\cdots$ & -- & $\cdots$ & 24.2 & 6.4 & 9.5 \\
\hline \multirow[t]{4}{*}{01186300} & Streamflow & .51 & .70 & 1.17 & 1.83 & 2.55 & 3.38 & 4.34 & 5.49 & 8.76 & -- & 2.61 & .40 & 1.11 \\
\hline & Variance & .00346 & .00241 & .00126 & .00082 & .00084 & .00108 & .00146 & .00195 & .00328 & -- & .00089 & .00493 & .0016 \\
\hline & Standard error & 13.6 & 11.3 & 8.2 & 6.6 & 6.7 & 7.6 & 8.8 & 10.2 & 13.2 & -- & 6.9 & 16.3 & 9.2 \\
\hline & Years & 39.6 & 42.9 & 51.1 & 54.1 & 49.3 & 41.3 & 32.9 & 26.3 & 16.7 & -- & 34.3 & 6.7 & 12.1 \\
\hline \multirow[t]{4}{*}{01187400} & Streamflow & .30 & .40 & .50 & .80 & 1.00 & 1.60 & 2.20 & 3.00 & 5.00 & 7.20 & -- & .24 & .46 \\
\hline & Variance & .00012 & .00010 & .00008 & .00006 & .00005 & .00004 & .00004 & .00004 & .00003 & .00003 & .. & .00435 & .00239 \\
\hline & Standard error & 2.5 & 2.3 & 2.0 & 1.8 & 1.6 & 1.5 & 1.4 & 1.4 & 1.3 & 1.3 & -- & 15.3 & 11.3 \\
\hline & Years & 31 & 31 & 31 & 31 & 31 & 31 & 31 & 31 & 31 & 31 & -- & 31 & 31 \\
\hline \multirow[t]{4}{*}{01197015} & Streamflow & 1.20 & 1.30 & 1.40 & 1.60 & 2.17 & 2.70 & 3.60 & 4.40 & 8.34 & 9.90 & 2.35 & -- & -- \\
\hline & Variance & .00117 & .00098 & .00074 & .00057 & .00048 & .00043 & .00039 & .00036 & .00032 & .00031 & .00066 & -- &.- \\
\hline & Standard error & 7.9 & 7.2 & 6.3 & 5.5 & 5.1 & 4.8 & 4.5 & 4.4 & 4.2 & 4.1 & 5.9 & -- &.. \\
\hline & Years & 2 & 2 & 2 & 2 & 2 & 2 & 2 & 2 & 2 & 2 & 2 & -- & -- \\
\hline
\end{tabular}


Table 9. Streamflow statistics, variances, standard errors, and years of record for stations included in the regression analyses; streamflow statistics are computed from daily records for streamgaging stations and estimated for low-flow partial-record stations; equivalent years of record for low-flow partial-record stations are computed from equation $14-$ Continued

\begin{tabular}{|c|c|c|c|c|c|c|c|c|c|c|c|c|c|c|}
\hline \multirow{2}{*}{$\begin{array}{c}\text { Station } \\
\text { No. }\end{array}$} & \multirow{2}{*}{ Statistic } & \multicolumn{10}{|c|}{ Flow-duration percentile } & \multirow{2}{*}{$\begin{array}{l}\text { August } \\
\text { median }\end{array}$} & \multirow{2}{*}{$\begin{array}{l}\text { 7-Day, } \\
\text { 10-year } \\
\text { low flow }\end{array}$} & \multirow{2}{*}{$\begin{array}{l}\text { 7-Day, } \\
\text { 2-year } \\
\text { low flow }\end{array}$} \\
\hline & & 99 & 98 & 95 & 90 & 85 & 80 & 75 & 70 & 60 & 50 & & & \\
\hline \multirow[t]{4}{*}{01197120} & Streamflow & 1.63 & 1.96 & 2.76 & 4.15 & 5.57 & 7.16 & 9.05 & 11.3 & -- & -. & 5.90 & 1.45 & 2.67 \\
\hline & Variance & .00225 & .00164 & .00083 & .00068 & .00101 & .0016 & .00238 & .00337 & -- & - & .00118 & .00325 & .00118 \\
\hline & Standard error & 11.0 & 9.3 & 6.6 & 6.0 & 7.3 & 9.2 & 11.3 & 13.4 & -- & - & 7.9 & 13.2 & 7.9 \\
\hline & Years & 39.7 & 41.2 & 47.1 & 44.2 & 35.1 & 27.7 & 21.8 & 17.2 & .. & $\cdots$ & 22.9 & 7.1 & 13.5 \\
\hline \multirow[t]{4}{*}{01197140} & Streamflow & .16 & .21 & .36 & .63 & .95 & 1.39 & 1.94 & - & -. & - & 1.02 & .12 & .34 \\
\hline & Variance & .00692 & .00528 & .00328 & .00216 & .00209 & .00258 & .00343 & - & -- & - & .00219 & .00957 & .00391 \\
\hline & Standard error & 19.3 & 16.8 & 13.2 & 10.7 & 10.6 & 11.7 & 13.5 & -- & -- & -. & 10.8 & 22.8 & 14.5 \\
\hline & Years & 37.5 & 39.2 & 42 & 44.9 & 43.3 & 38.4 & 31.4 & -. & - & $\cdots$ & 29.8 & 6.4 & 8.6 \\
\hline \multirow[t]{4}{*}{01197180} & Streamflow & -- & 1.85 & 2.25 & 2.68 & 3.13 & 3.54 & 4.00 & 4.43 & 5.45 & 6.47 & 3.13 & 1.49 & 2.17 \\
\hline & Variance & -- & .00057 & .00035 & .00032 & .00042 & .00059 & .00082 & .00107 & .00174 & .00245 & .00043 & .00111 & .00042 \\
\hline & Standard error & -- & 5.5 & 4.3 & 4.1 & 4.7 & 5.6 & 6.6 & 7.5 & 9.6 & 11.4 & 4.8 & 7.7 & 4.7 \\
\hline & Years & $-\cdot$ & 52.8 & 60.9 & 54.8 & 42.3 & 31.7 & 23.3 & 17.8 & 10.9 & 7.8 & 25.3 & 7 & 9.8 \\
\hline \multirow[t]{4}{*}{01197230} & Streamflow & 1.70 & 2.09 & 2.84 & -- & 4.91 & 6.06 & 7.26 & 8.63 & 11.9 & 15.5 & 4.98 & 1.50 & 2.77 \\
\hline & Variance & .00088 & .00062 & .00043 & -. & .00063 & .0009 & .0012 & .00156 & .00239 & .00328 & .00067 & .00138 & .00062 \\
\hline & Standard error & 6.8 & 5.7 & 4.8 & -- & 5.8 & 6.9 & 8.0 & 9.1 & 11.3 & 13.2 & 6.0 & 8.6 & 5.7 \\
\hline & Years & 47.6 & 49.7 & 49.4 & -- & 37.8 & 30.6 & 24.3 & 19.6 & 13.3 & 10.1 & 26.4 & 11.9 & 15 \\
\hline \multirow[t]{4}{*}{01197300} & Streamflow & .010 & .020 & .060 & .21 & .38 & .55 & .83 & 1.10 & 1.60 & 2.40 & .47 & -- & -- \\
\hline & Variance & .00064 & .00053 & .00040 & .00031 & .00026 & .00023 & .00021 & .00020 & .00018 & .00017 & .00275 & -- & -- \\
\hline & Standard error & 5.8 & 5.3 & 4.6 & 4.1 & 3.7 & 3.5 & 3.3 & 3.2 & 3.1 & 3.0 & 12.1 & -- & -- \\
\hline & Years & 9 & 9 & 9 & 9 & 9 & 9 & 9 & 9 & 9 & 9 & 9 & -- & -- \\
\hline \multirow[t]{4}{*}{01198000} & Streamflow & 3.20 & 3.70 & 4.70 & 6.40 & 8.50 & 12.0 & 15.0 & 19.0 & 30.4 & 42.0 & 9.10 & 3.11 & -- \\
\hline & Variance & .00014 & .00012 & .00009 & .00007 & .00006 & .00005 & .00005 & .00004 & .00004 & .00004 & .00020 & .00320 & -- \\
\hline & Standard error & 2.7 & 2.5 & 2.2 & 1.9 & 1.8 & 1.7 & 1.6 & 1.5 & 1.4 & 1.4 & 3.3 & 13.1 & -- \\
\hline & Years & 21 & 21 & 21 & 21 & 21 & 21 & 21 & 21 & 21 & 21 & 21 & 21 & -- \\
\hline \multirow[t]{4}{*}{01198060} & Streamflow & -- & -- & -- & -- & - & - & - & -. & .. & $\ldots$ & -- & .017 & .092 \\
\hline & Variance & -- & .- & .. & - & .. & -- & -- & -- & - & -- & .. & .01321 & .00643 \\
\hline & Standard error & .. & -- & -- & -- & -- & -- & -- & -- & - & -. & -- & 26.9 & 18.6 \\
\hline & Years & -- & - & -- & -- & -. & .. & .. & -- & -- & - & -- & 11.2 & 12.6 \\
\hline \multirow[t]{4}{*}{01198160} & Streamflow & .68 & .80 & 1.03 & 1.34 & 1.67 & 2.00 & 2.33 & 2.70 & 3.57 & 4.50 & 1.70 & .59 & 1.02 \\
\hline & Variance & .00142 & .00111 & .0008 & .00069 & .00078 & .00097 & .00122 & .00152 & .0023 & .00313 & .00081 & .00212 & .00101 \\
\hline & Standard error & 8.7 & 7.7 & 6.5 & 6.1 & 6.4 & 7.2 & 8.1 & 9.0 & 11.1 & 12.9 & 6.6 & 10.6 & 7.3 \\
\hline & Years & 44.6 & 46.2 & 46.9 & 45.3 & 40.4 & 34.9 & 29 & 24.2 & 16.7 & 12.9 & 29 & 9.6 & 11.2 \\
\hline
\end{tabular}


Table 9. Streamflow statistics, variances, standard errors, and years of record for stations included in the regression analyses; streamflow statistics are computed from daily records for streamgaging stations and estimated for low-flow partial-record stations; equivalent years of record for low-flow partial-record stations are computed from equation 14-Continued

\begin{tabular}{|c|c|c|c|c|c|c|c|c|c|c|c|c|c|c|}
\hline \multirow{2}{*}{$\begin{array}{c}\text { Station } \\
\text { No. }\end{array}$} & \multirow{2}{*}{ Statistic } & \multicolumn{10}{|c|}{ Flow-duration percentile } & \multirow{2}{*}{$\begin{array}{l}\text { August } \\
\text { median }\end{array}$} & \multirow{2}{*}{$\begin{array}{l}\text { 7-Day, } \\
\text { 10-year } \\
\text { low flow }\end{array}$} & \multirow{2}{*}{$\begin{array}{l}\text { 7-Day, } \\
\text { 2-year } \\
\text { low flow }\end{array}$} \\
\hline & & 99 & 98 & 95 & 90 & 85 & 80 & 75 & 70 & 60 & 50 & & & \\
\hline \multirow[t]{4}{*}{01198200} & Streamflow & - & -- & 19.1 & 24.5 & 29.6 & 35.7 & 41.3 & 47.4 & 61.0 & 75.9 & 30.6 & - & -- \\
\hline & Variance & -- & -- & .00017 & .00014 & .00012 & .00011 & .0001 & .0001 & .0001 & .00011 & .00013 & -- & .. \\
\hline & Standard error & -- & -- & 3.0 & 2.7 & 2.5 & 2.4 & 2.3 & 2.3 & 2.3 & 2.5 & 2.6 & -. & -- \\
\hline & Years & - & -- & 37.3 & 36.9 & 36.6 & 36.2 & 35.8 & 35.3 & 34.3 & 33.3 & 31.8 & -- & .. \\
\hline \multirow[t]{4}{*}{01331380} & Streamflow & .48 & .54 & .72 & .96 & 1.17 & 1.44 & 1.78 & 2.16 & 3.20 & -- & 1.22 & .44 & .70 \\
\hline & Variance & .00343 & .00253 & .00131 & .00069 & .00058 & .0007 & .00107 & .00159 & .00288 & -r & .00061 & .00446 & .00169 \\
\hline & Standard error & 13.5 & 11.6 & 8.3 & 6.1 & 5.5 & 6.1 & 7.5 & 9.2 & 12.4 & - & 5.7 & 15.5 & 9.5 \\
\hline & Years & 39.7 & 41.4 & 46.1 & 51.8 & 52.8 & 49.4 & 42.6 & 35.7 & 25.1 & - & 40.8 & 7 & 10 \\
\hline \multirow[t]{4}{*}{01331400} & Streamflow & .17 & .27 & .57 & 1.10 & 1.60 & 2.00 & 2.60 & 3.37 & 5.20 & 7.30 & 1.90 & -- & -- \\
\hline & Variance & .00044 & .00037 & .00028 & .00022 & .00018 & .00016 & .00015 & .00014 & .00012 & .00012 & .00209 & -- & -- \\
\hline & Standard error & 4.8 & 4.4 & 3.9 & 3.4 & 3.1 & 2.9 & 2.8 & 2.7 & 2.6 & 2.5 & 10.6 & -- & -- \\
\hline & Years & 10 & 10 & 10 & 10 & 10 & 10 & 10 & 10 & 10 & 10 & 10 & -- & -- \\
\hline \multirow[t]{4}{*}{01332000} & Streamflow & 5.70 & 6.50 & 8.50 & 11.0 & 14.4 & 19.0 & 23.0 & -- & - & 49.0 & 14.0 & 5.21 & 7.77 \\
\hline & Variance & .0000409 & .0000343 & .000026 & .0000201 & .000017 & .0000149 & .0000135 & -- & -- & .00001 & .0000834 & .0007938 & .0004359 \\
\hline & Standard error & 1.5 & 1.3 & 1.2 & 1.0 & .9 & .9 & .8 & -- & -- & .8 & 2.1 & 6.5 & 4.8 \\
\hline & Years & 58 & 58 & 58 & 58 & 58 & 58 & 58 & - & .. & 58 & 58 & 58 & 58 \\
\hline \multirow[t]{4}{*}{01332900} & Streamflow & -- & .. & -- & 1.67 & 2.01 & 2.70 & -- & -- & .. & 7.98 & 2.13 & 1.34 & 1.45 \\
\hline & Variance & .. & - & -- & .00029 & .00026 & .00032 & -- & -- & -- & .00166 & .00029 & .00202 & .00086 \\
\hline & Standard error & -- & .. & -- & 3.9 & 3.7 & 4.1 & - & -- & -- & 9.4 & 3.9 & 10.4 & 6.8 \\
\hline & Years & - & -- & -- & 57.1 & 56.6 & 54.4 & -- & -- & -- & 33.4 & 49.7 & 19.2 & 23.6 \\
\hline \multirow[t]{4}{*}{01333000} & Streamflow & 4.80 & 5.60 & 7.80 & 11.0 & 14.0 & 18.2 & 23.0 & 27.0 & 36.0 & 48.0 & 15.0 & 4.57 & 8.19 \\
\hline & Variance & .00005 & .00004 & .00003 & .00002 & .00002 & .00002 & .00002 & .00001 & .00001 & .00001 & .00009 & .00171 & .00094 \\
\hline & Standard error & 1.6 & 1.4 & 1.2 & 1.1 & 1.0 & .9 & .9 & .9 & .8 & .8 & 2.2 & 9.5 & 7.1 \\
\hline & Years & 47 & 47 & 47 & 47 & 47 & 47 & 47 & 47 & 47 & 47 & 47 & 47 & 47 \\
\hline \multirow[t]{4}{*}{01333100} & Streamflow & $\cdots$ & -- & -- & -. & -- & -- & 1.26 & 1.67 & 2.68 & 4.29 & - & .10 & .22 \\
\hline & Variance & - & -. & .. & -- & -- & -. & .00111 & .00136 & .00201 & .00295 & -. & .00564 & .00301 \\
\hline & Standard error & -- & -- & -- & -- & -- & -- & 7.7 & 8.5 & 10.4 & 12.6 & - & 17.4 & 12.7 \\
\hline & Years &.- & -- & -- & -- & -. & - & 45.9 & 43.8 & 39.4 & 34.9 & -. & 16.1 & 17.7 \\
\hline \multirow[t]{4}{*}{01359967} & Streamflow & 2.43 & 2.75 & 3.66 & 4.74 & 4.94 & 5.11 & 5.77 & 6.80 & 9.09 & 11.3 & 4.96 & 2.29 & 3.74 \\
\hline & Variance & .00291 & .00214 & .00093 & .00051 & .00057 & .00041 & .0005 & .00088 & .00214 & .00354 & .00057 & .00366 & .00099 \\
\hline & Standard error & 12.5 & 10.7 & 7.0 & 5.2 & 5.5 & 4.7 & 5.2 & 6.8 & 10.7 & 13.8 & 5.5 & 14.0 & 7.3 \\
\hline & Years & 24.4 & 27.2 & 42.4 & 57.5 & 28.7 & 21.4 & 19.3 & 16.1 & 9.6 & 6.6 & 17.3 & 4 & 9.9 \\
\hline
\end{tabular}


Tabie 10. Basin characteristics for stations used in the regression analyses

[Flows are in cubic feet per second; areas are in square miles; lengths are in miles; slopes are in percent; elevations are in feet. Region: 0 is eastern; 1 is western; No., number; -- , no data]

\begin{tabular}{|c|c|c|c|c|c|c|c|c|c|c|}
\hline Station No. & $\begin{array}{l}\text { Drainage } \\
\text { area }\end{array}$ & $\begin{array}{c}\text { Total } \\
\text { stream } \\
\text { length }\end{array}$ & $\begin{array}{l}\text { Mean } \\
\text { basin } \\
\text { slope }\end{array}$ & $\begin{array}{l}\text { Stratified- } \\
\text { drift area }\end{array}$ & $\begin{array}{l}\text { Area of } \\
\text { water } \\
\text { bodies }\end{array}$ & $\begin{array}{c}\text { Area of } \\
\text { wetlands }\end{array}$ & $\begin{array}{l}\text { Minimum } \\
\text { basin } \\
\text { elevation }\end{array}$ & $\begin{array}{l}\text { Mean basin } \\
\text { elevatlon }\end{array}$ & $\begin{array}{l}\text { Maximum } \\
\text { basin } \\
\text { elevation }\end{array}$ & Region \\
\hline 01073860 & 1.83 & 4.21 & 0.84 & 1.80 & 0.00 & 0.00 & 22 & 65 & 108 & 0 \\
\hline 01094340 & 21.7 & 38.6 & 4.57 & 3.78 & .77 & .70 & 670 & 1,000 & 1,340 & 0 \\
\hline 01094396 & 15.8 & 32.3 & 6.41 & 1.40 & .25 & .40 & 567 & 1,050 & 1,580 & 0 \\
\hline 01094760 & 7.41 & 12.7 & 3.81 & 1.62 & .52 & .23 & 423 & 615 & 806 & 0 \\
\hline 01095220 & 30.4 & 50.7 & 5.80 & 5.41 & .47 & .80 & 403 & 1,150 & 2,000 & 0 \\
\hline 01095380 & 6.79 & 11.6 & 3.99 & 1.95 & .02 & .41 & 532 & 806 & 1,080 & 0 \\
\hline 01095915 & 15.7 & 23.6 & 3.02 & 4.53 & .50 & .02 & 241 & 312 & 403 & 0 \\
\hline 01095928 & 5.89 & 13.3 & 4.93 & .66 & .02 & .22 & 482 & 893 & 1,300 & 0 \\
\hline 01096000 & 64.4 & 125 & 5.07 & 17.1 & .40 & 1.35 & 252 & 855 & 1,500 & 0 \\
\hline 01096504 & 1.92 & 3.26 & 1.93 & 1.52 & .02 & .30 & 181 & 300 & 428 & 0 \\
\hline 01096505 & 6.84 & 12.7 & 2.28 & 4.62 & .02 & .52 & 177 & 332 & 514 & 0 \\
\hline 01096515 & 18.2 & 30.7 & 2.86 & 11.3 & .91 & .36 & 174 & 234 & 397 & 0 \\
\hline 01096805 & 15.4 & 42.6 & 4.54 & 3.43 & .15 & .57 & 216 & 450 & 701 & 0 \\
\hline 01096855 & 6.62 & 18.5 & 3.71 & 1.76 & .05 & .57 & 234 & 446 & 661 & 0 \\
\hline 01096910 & 1.61 & 2.99 & 3.66 & .18 & .00 & .00 & 298 & 441 & 582 & 0 \\
\hline 01096935 & 17.2 & 42.4 & 3.92 & 5.55 & .37 & .71 & 205 & 422 & 640 & 0 \\
\hline 01097280 & 24.9 & 57.4 & 2.28 & 7.70 & .49 & 1.56 & 126 & 295 & 470 & 0 \\
\hline 01097300 & 12.9 & 33.7 & 2.39 & 7.45 & .09 & .96 & 158 & 314 & 463 & 0 \\
\hline 01099400 & 25.6 & 48.1 & 2.01 & 15.8 & .47 & 1.60 & 98 & 249 & 403 & 0 \\
\hline 01100608 & 4.09 & 10.2 & 1.37 & 2.17 & .13 & .12 & 104 & 229 & 354 & 0 \\
\hline 01100700 & 5.54 & 10.1 & 2.78 & 1.72 & .07 & .21 & 95 & 213 & 334 & 0 \\
\hline 01101000 & 21.4 & 56.4 & 5.52 & 9.92 & .50 & 2.16 & 32 & 193 & 354 & 0 \\
\hline 01101100 & 7.70 & 25.6 & 4.67 & 5.51 & .07 & .56 & 26 & 130 & 252 & 0 \\
\hline 01102053 & 2.72 & 4.88 & 1.99 & 1.72 & .01 & .02 & 26 & 96 & 167 & 0 \\
\hline 01102490 & 3.05 & 5.06 & 3.21 & .34 & .01 & .04 & 50 & 202 & 364 & 0 \\
\hline 01103015 & 5.35 & 10.5 & 3.21 & 2.26 & .05 & .13 & 15 & 194 & 377 & 0 \\
\hline 01103253 & 7.23 & 18.5 & 2.29 & 1.09 & .06 & .36 & 172 & 306 & 445 & 0 \\
\hline 01103435 & 10.2 & 19.0 & 1.81 & 6.24 & .50 & .48 & 110 & 236 & 370 & 0 \\
\hline 01103440 & 3.91 & 7.03 & 1.58 & 2.35 & .01 & .47 & 118 & 214 & 336 & 0 \\
\hline 01104960 & 2.37 & 4.18 & 1.65 & .67 & .07 & .10 & 113 & 213 & 334 & 0 \\
\hline
\end{tabular}


Table 10. Basin characteristics for stations used in the regression analyses-Continued

\begin{tabular}{|c|c|c|c|c|c|c|c|c|c|c|}
\hline Station No. & $\begin{array}{l}\text { Drainage } \\
\text { area }\end{array}$ & $\begin{array}{c}\text { Total } \\
\text { stream } \\
\text { length }\end{array}$ & $\begin{array}{l}\text { Mean } \\
\text { basin } \\
\text { slope }\end{array}$ & $\begin{array}{l}\text { Stratified- } \\
\text { drift area }\end{array}$ & $\begin{array}{c}\text { Area of } \\
\text { water } \\
\text { bodies }\end{array}$ & $\begin{array}{c}\text { Area of } \\
\text { wetlands }\end{array}$ & $\begin{array}{l}\text { Minimum } \\
\text { basin } \\
\text { elevation }\end{array}$ & $\begin{array}{l}\text { Mean basin } \\
\text { elevation }\end{array}$ & $\begin{array}{c}\text { Maximum } \\
\text { basin } \\
\text { elevation }\end{array}$ & Region \\
\hline 01104980 & 8.64 & 15.5 & 2.27 & 2.20 & 0.46 & 0.31 & 59 & 222 & 396 & 0 \\
\hline 01105100 & 3.40 & 5.84 & 3.03 & 1.96 & .01 & .05 & 79 & 271 & 484 & 0 \\
\hline 01105270 & 10.4 & 29.4 & 2.50 & 6.45 & .72 & .73 & 104 & 284 & 490 & 0 \\
\hline 01105568 & 4.31 & 6.53 & 1.30 & 2.04 & .05 & .05 & 118 & 180 & 241 & 0 \\
\hline 01105575 & 1.72 & 1.79 & 2.13 & .00 & .01 & .09 & 115 & 182 & 259 & 0 \\
\hline 01105582 & 27.4 & 48.7 & 2.33 & 10.8 & 1.01 & 1.86 & 59 & 330 & 630 & 0 \\
\hline 01105600 & 4.47 & 8.03 & 1.27 & 1.50 & .00 & .26 & 75 & 137 & 200 & 0 \\
\hline 01105630 & 4.91 & 10.9 & 1.63 & 3.64 & .06 & .21 & 29 & 104 & 180 & 0 \\
\hline 01105670 & 1.61 & 2.47 & .81 & .15 & .00 & .06 & 6 & 65 & 124 & 0 \\
\hline 01105820 & 3.17 & 6.09 & 1.14 & .77 & .05 & .28 & 42 & 154 & 221 & 0 \\
\hline 01105830 & 1.72 & 3.19 & .61 & .08 & .00 & .20 & 62 & 131 & 200 & 0 \\
\hline 01105861 & 4.74 & 7.92 & 1.06 & 4.22 & .06 & .00 & 39 & 94 & 170 & 0 \\
\hline 011058839 & 6.87 & 5.34 & .2 .21 & 6.87 & 1.10 & .02 & 42 & 118 & 193 & 0 \\
\hline 011059106 & 2.58 & 3.46 &. .61 & 1.64 & .02 & .50 & 52 & 70 & 88 & 0 \\
\hline 01105930 & 8.09 & 17.4 & 1.24 & 3.63 & .16 & 2.40 & 75 & 155 & 236 & 0 \\
\hline 01105935 & 2.64 & 5.76 & 1.82 & 1.44 & .01 & .43 & 41 & 109 & 179 & 0 \\
\hline 01105937 & 8.59 & 15.3 & 1.52 & 3.27 & .02 & .76 & 70 & 170 & 270 & 0 \\
\hline 01105947 & 9.25 & 18.3 & .90 & 1.43 & .01 & 1.03 & 19 & 155 & 296 & 0 \\
\hline 01106000 & 7.99 & 17.6 & 1.51 & .18 & -- & -- & 10 & 178 & 227 & 0 \\
\hline 01106460 & 8.94 & 17.3 & 1.50 & 3.30 & .19 & .91 & 55 & 175 & 259 & 0 \\
\hline 01107000 & 4.71 & 9.61 & 1.10 & .88 & .04 & .25 & 118 & 209 & 301 & 0 \\
\hline 01107400 & 9.30 & 15.4 & 1.04 & 7.21 & .45 & 1.32 & 49 & 111 & 173 & 0 \\
\hline 01108140 & 8.20 & 16.0 & 1.09 & 6.98 & .18 & .89 & 32 & 82 & 131 & 0 \\
\hline 01108180 & 7.48 & 11.6 & .96 & 3.69 & .05 & .61 & 15 & 92 & 183 & 0 \\
\hline 01108600 & 3.83 & 11.4 & .96 & 2.49 & .01 & .19 & 124 & 214 & 305 & 0 \\
\hline 01109087 & 20.7 & 37.0 & 1.42 & 9.37 & .15 & 2.53 & 27 & 138 & 249 & 0 \\
\hline 01109090 & 4.22 & 6.19 & 1.81 & 1.51 & .03 & .11 & 23 & 172 & 326 & 0 \\
\hline 01109200 & 4.33 & 9.25 & .32 & 2.78 & .02 & .42 & 101 & 160 & 255 & 0 \\
\hline 01109225 & 7.21 & 11.6 & 1.11 & 2.85 & .02 & 1.18 & 19 & 109 & 200 & 0 \\
\hline 01109460 & 11.1 & 31.1 & 3.46 & 2.91 & .51 & .44 & 491 & 680 & 869 & 0 \\
\hline
\end{tabular}


Table 10. Basin characteristics for stations used in the regression analyses-Continued

\begin{tabular}{|c|c|c|c|c|c|c|c|c|c|c|}
\hline Station No. & $\begin{array}{l}\text { Drainage } \\
\text { area }\end{array}$ & $\begin{array}{c}\text { Total } \\
\text { stream } \\
\text { length }\end{array}$ & $\begin{array}{l}\text { Mean } \\
\text { basin } \\
\text { slope }\end{array}$ & $\begin{array}{l}\text { Stratified- } \\
\text { drift area }\end{array}$ & $\begin{array}{c}\text { Area of } \\
\text { water } \\
\text { bodies }\end{array}$ & $\begin{array}{c}\text { Area of } \\
\text { wetlands }\end{array}$ & $\begin{array}{l}\text { Minimum } \\
\text { basin } \\
\text { elevation }\end{array}$ & $\begin{array}{l}\text { Mean basin } \\
\text { elevation }\end{array}$ & $\begin{array}{l}\text { Maximum } \\
\text { basin } \\
\text { elevation }\end{array}$ & Region \\
\hline 01111142 & 5.67 & 11.7 & 3.98 & $1: 30$ & 0.05 & 0.65 & 350 & 505 & 659 & 0 \\
\hline 01111200 & 27.8 & 69.9 & 4.43 & 8.45 & .27 & 1.77 & 247 & 424 & 659 & 0 \\
\hline 01111225 & 7.26 & 17.2 & 3.15 & 2.60 & .08 & .19 & 270 & 456 & 641 & 0 \\
\hline 01111300 & 16.0 & 30.0 & 3.14 & 4.60 &.- & -- & 348 & 572 & 773 & 0 \\
\hline 01112190 & 6.17 & 16.2 & 3.38 & .95 & .02 & .17 & 200 & 371 & 587 & 0 \\
\hline 01123140 & 13.8 & 39.2 & 6.33 & 3.27 & .17 & .57 & 652 & 943 & 1,250 & 0 \\
\hline 01123161 & 6.57 & 15.3 & 5.96 & 1.88 & .16 & .24 & 653 & 915 & 1,180 & 0 \\
\hline 01123200 & 4.39 & 12.9 & 4.63 & .18 & .02 & .20 & 690 & 986 & 1,290 & 0 \\
\hline 01124390 & 8.58 & 28.5 & 3.82 & .00 & .16 & .50 & 564 & 828 & 1,090 & 0 \\
\hline 01162500 & 19.2 & 13.9 & 3.68 & 2.01 & .01 & .52 & 851 & 1,280 & 1,870 & 1 \\
\hline 01162900 & 19.2 & 32.2 & 2.82 & 6.17 & .45 & 1.19 & 913 & 1,110 & 1,310 & 1 \\
\hline 01163298 & 7.22 & 10.9 & 3.09 & 2.59 & .09 & .21 & 834 & 995 & 1,160 & 1 \\
\hline 01164300 & 15.6 & 26.8 & 4.06 & 2.80 & .54 & .73 & 856 & 1,360 & 1,880 & 1 \\
\hline 01165090 & 14.1 & 20.8 & 7.64 & 1.45 & .05 & .18 & 560 & 977 & 1,400 & 1 \\
\hline 01165250 & 7.08 & 11.2 & 4.34 & 1.45 & .16 & .17 & 623 & 961 & 1,300 & 1 \\
\hline 01165500 & 12.1 & 15.0 & 6.93 & 1.92 & .14 & .17 & 511 & 999 & 1,620 & 1 \\
\hline 01166105 & 5.24 & 10.6 & 7.39 & 1.24 & .00 & .05 & 478 & 983 & 1,300 & 1 \\
\hline 01167200 & 22.3 & 38.6 & 10.6 & 1.15 & .05 & .03 & 395 & 858 & 1,400 & 1 \\
\hline 01168300 & 29.6 & 57.0 & 11.0 & .20 & .17 & .20 & 751 & 1,940 & 2,830 & 1 \\
\hline 01168400 & 27.1 & 55.5 & 12.1 & .91 & .14 & .13 & 613 & 1,790 & 2,510 & 1 \\
\hline 01168650 & 18.1 & 36.7 & 11.1 & 2.17 & .04 & .07 & 483 & 1,330 & 1,900 & 1 \\
\hline 01169000 & 89.8 & 175 & 9.70 & 5.41 & .08 & .20 & 475 & 1,350 & 2,230 & 1 \\
\hline 01169600 & 10.5 & 21,4 & 8.49 & 1.06 & .01 & .01 & 587 & 1,070 & 1,550 & 1 \\
\hline 01169800 & 6.69 & 13.6 & 8.22 & .24 & .02 & .07 & 776 & 1,310 & 1,700 & 1 \\
\hline 01169801 & 15.6 & 31.2 & 8.72 & 1.89 & .09 & .08 & 820 & 1,280 & 1,830 & $\cdot 1$ \\
\hline 01169900 & 24.1 & 48.1 & 9.45 & 3,20 & .10 & .08 & 485 & 1,150 & 1,830 & 1 \\
\hline 01170100 & 41.3 & 84.2 & 9.52 & 1.48 & .01 & .03 & 475 & 1,360 & 2,400 & 1 \\
\hline 01170575 & 21.7 & 39.7 & 6.86 & 4.43 & .32 & .10 & 296 & 907 & 1,300 & 1 \\
\hline 01171500 & 54.0 & 100 & 6.91 & 9.52 & .53 & .54 & 141 & 848 & 1,690 & 1 \\
\hline 01171800 & 5.56 & 9.17 & 5.20 & 2.04 & .03 & .11 & 209 & 514 & 829 & 1 \\
\hline
\end{tabular}


Table 10. Basin characteristics for stations used in the regression analyses-Continued

\begin{tabular}{|c|c|c|c|c|c|c|c|c|c|c|}
\hline Station No. & $\begin{array}{c}\text { Drainage } \\
\text { area }\end{array}$ & $\begin{array}{l}\text { Total } \\
\text { stream } \\
\text { length }\end{array}$ & $\begin{array}{l}\text { Mean } \\
\text { basin } \\
\text { slope }\end{array}$ & $\begin{array}{l}\text { Stratified- } \\
\text { drift area }\end{array}$ & $\begin{array}{l}\text { Area of } \\
\text { water } \\
\text { bodies }\end{array}$ & $\begin{array}{c}\text { Area of } \\
\text { wetlands }\end{array}$ & $\begin{array}{c}\text { Minimum } \\
\text { basin } \\
\text { elevation }\end{array}$ & $\begin{array}{c}\text { Mean basin } \\
\text { elevation }\end{array}$ & $\begin{array}{c}\text { Maximum } \\
\text { basin } \\
\text { elevation }\end{array}$ & Region \\
\hline 01171947 & 18.4 & 34.4 & 3.46 & 8.20 & 0.25 & 1.31 & 292 & 394 & 797 & 1 \\
\hline 01171970 & 18.8 & 31.2 & 1.41 & 10.9 & .10 & .88 & 167 & 401 & 643 & 1 \\
\hline 01172810 & 12.7 & 17.8 & 3.61 & 2.47 & .03 & .59 & 713 & 1,010 & 1,310 & 1 \\
\hline 01173260 & 4.62 & 4.01 & 1.66 & .00 & .03 & .58 & 927 & 1,070 & 1,220 & 1 \\
\hline 01173420 & 19.0 & 33.4 & 5.44 & 4.54 & .25 & 1.23 & 432 & 699 & 986 & 1 \\
\hline 01173450 & 6.60 & 10.8 & 4.27 & 1.00 & .02 & .46 & 432 & 699 & 986 & 1 \\
\hline 01174000 & 3.39 & 7.97 & 6.53 & .07 & .01 & .00 & 730 & 1,000 & 1,300 & 1 \\
\hline 01174050 & 5.03 & 6.29 & 4.60 & .72 & .17 & .25 & 706 & 931 & 1,220 & 1 \\
\hline 01174565 & 12.5 & 27.9 & 7.47 & 1.94 & .08 & .04 & 593 & 823 & 1,040 & 1 \\
\hline 01174900 & 2.89 & 5.99 & 5.96 & .02 & .00 & .01 & 539 & 860 & 1,160 & 1 \\
\hline 01175670 & 8.69 & 16.74 & 5.46 & 1.11 & .21 & .30 & 650 & 864 & 1,080 & 1 \\
\hline 01175710 & 13.8 & 28.8 & 3.87 & 2.16 & .43 & .83 & 664 & 908 & 1,150 & 1 \\
\hline 01175850 & 11.5 & 25.6 & 4.67 & 1.93 & .08 & .52 & 613 & 880 & 1,160 & 1 \\
\hline 01175890 & 3.55 & 7.68 & 5.64 & 0.67 & .01 & .09 & 609 & 857 & 1,100 & 1 \\
\hline 01176000 & 149 & 319 & 4.51 & 31.7 & 4.36 & 8.28 & 387 & 792 & 1,220 & 1 \\
\hline 01176100 & 9.34 & 20.8 & 4.88 & 2.86 & .03 & .52 & 373 & 775 & 1,220 & 1 \\
\hline 01176200 & 3.96 & 4.91 & 7.07 & 1.08 & .01 & .17 & 373 & 684 & 1,040 & 1 \\
\hline 01176300 & 6.57 & 8.76 & 8.54 & 1.41 & .05 & .13 & 408 & 806 & 1,210 & 1 \\
\hline 01176415 & 15.3 & 18.9 & 5.80 & 3.54 & .32 & .28 & 396 & 819 & 1,260 & 1 \\
\hline 01176780 & 13.6 & 22.0 & 5.57 & 2.83 & .08 & .26 & 260 & 647 & 1,050 & 1 \\
\hline 01177360 & 6.92 & 12.5 & 3.20 & 4.57 & .03 & .54 & 243 & 332 & 850 & 1 \\
\hline 01178200 & 11.1 & 19.2 & 5.79 & .22 & .01 & .10 & 1,360 & 1,860 & 2,300 & 1 \\
\hline 01178300 & 22.9 & 38.8 & 4.86 & .80 & .17 & .48 & 961 & 1,410 & 1,870 & 1 \\
\hline 01178490 & 12.3 & 26.0 & 5.78 & .26 & .01 & .00 & 747 & 1,410 & 2,070 & 1 \\
\hline 01179900 & 6.46 & 6.78 & 5.34 & .19 & .01 & .07 & 1,460 & 1,830 & 2,120 & 1 \\
\hline 01180000 & 1.74 & 2.54 & 9.72 & .00 & .01 & .15 & 637 & 1,010 & 1,340 & 1 \\
\hline 01180500 & 52.8 & 97.8 & 8.50 & 1.50 & .46 & .51 & 412 & 1,320 & 2,240 & 1 \\
\hline 01180650 & 6.35 & 13.21 & 4.74 & .00 & .01 & .11 & 1,220 & 1,700 & 2,140 & 1 \\
\hline 01180800 & 2.95 & 6.98 & 4.76 & .12 & .05 & .03 & 1,280 & 1,550 & 1,820 & 1 \\
\hline 01181000 & 94.0 & 161 & 8.78 & 3.91 & 1.15 & 1.30 & 393 & 1,320 & 2,240 & 1 \\
\hline
\end{tabular}


Table 10. Basin characteristics for stations used in the regression analyses-Continued

\begin{tabular}{|c|c|c|c|c|c|c|c|c|c|c|}
\hline Station No. & $\begin{array}{c}\text { Drainage } \\
\text { area }\end{array}$ & $\begin{array}{l}\text { Total } \\
\text { stream } \\
\text { length }\end{array}$ & $\begin{array}{l}\text { Mean } \\
\text { basin } \\
\text { slope }\end{array}$ & $\begin{array}{l}\text { Stratified- } \\
\text { drift area }\end{array}$ & $\begin{array}{c}\text { Area of } \\
\text { water } \\
\text { bodies }\end{array}$ & $\begin{array}{c}\text { Area of } \\
\text { wetlands }\end{array}$ & $\begin{array}{c}\text { Minimum } \\
\text { basin } \\
\text { elevation }\end{array}$ & $\begin{array}{c}\text { Mean basin } \\
\text { elevation }\end{array}$ & $\begin{array}{c}\text { Maximum } \\
\text { basin } \\
\text { elevation }\end{array}$ & Region \\
\hline 01183210 & 22.2 & 43.2 & 8.39 & 5.02 & 0.28 & 0.29 & 209 & 829 & 1,460 & 1 \\
\hline 01184200 & 5.27 & 13.6 & 2.79 & 3.00 & .04 & .31 & 190 & 387 & 583 & 1 \\
\hline 01184277 & 24.4 & 49.6 & 7.70 & 5.58 & .07 & .25 & 399 & 786 & 1,210 & 1 \\
\hline 01184855 & 30.3 & 42.7 & 5.26 & 2.42 & .92 & 1.39 & 1,160 & 1,620 & 2,120 & 1 \\
\hline 01185490 & 29.1 & 46.8 & 6.69 & .19 & .71 & .89 & -- & -- & -- & 1 \\
\hline 01186300 & 9.87 & 15.9 & 3.83 & .59 & .09 & .79 & 1,280 & 1,540 & 1,810 & 1 \\
\hline 01187400 & 7.37 & 12.2 & 11.0 & .70 & .. & -. & 573 & 1,120 & 1,400 & 1 \\
\hline 01197015 & 10.6 & 20.8 & 11.1 & .54 & .01 & .04 & 1,110 & 1,790 & 2,630 & 1 \\
\hline 01197120 & 20.4 & 36.2 & 8.09 & .11 & .40 & .56 & 1,020 & 1,600 & 2,210 & 1 \\
\hline 01197140 & 5.95 & 7.50 & 8.59 & .03 & .03 & .37 & 969 & 1,550 & 2,160 & 1 \\
\hline 01197180 & 7.62 & 8.91 & 12.4 & .78 & .16 & .18 & 1,060 & 1,660 & 2,260 & 1 \\
\hline 01197230 & 22.2 & 25.6 & 10.7 & 2.79 & .19 & .46 & 846 & 1,400 & 1,960 & 1 \\
\hline 01197300 & 2.18 & 1.87 & 9.29 & .01 & .02 & .11 & 990 & 1,370 & 1,840 & 1 \\
\hline 01198000 & 51.0 & 76.6 & 9.49 & 5.13 & .38 & .32 & 688 & 1,290 & 2,060 & 1 \\
\hline 01198060 & 2.91 & 3.19 & 19.0 & .08 & .00 & .00 & 774 & 1,400 & 2,030 & 1 \\
\hline 01198160 & 8.46 & 18.9 & 6.22 & .27 & .05 & .27 & 1,010 & 1,490 & 1,850 & 1 \\
\hline 01198200 & 61.0 & 94.0 & 6.78 & 10.6 & 1.23 & 1.28 & 682 & 1,440 & 2,110 & 1 \\
\hline 01331380 & 7.03 & 12.8 & 10.5 & .02 & .00 & .02 & 979 & 1,640 & 2,260 & 1 \\
\hline 01331400 & 7.68 & 9.60 & 8.19 & .21 & .01 & .09 & 1,160 & 1,690 & 2,250 & 1 \\
\hline 01332000 & 40.9 & 58.5 & 13.5 & 3.10 & -- & -. & 830 & 1,950 & 3,080 & 1 \\
\hline 01332900 & 6.70 & 8.21 & 24.6 & .22 & .00 & .00 & 766 & 2,080 & 3,480 & 1 \\
\hline 01333000 & 42.6 & 73.2 & 18.5 & 4.90 & .03 & .00 & 629 & 2,020 & 3,480 & 1 \\
\hline 01333100 & 5.25 & 10.1 & 19.4 & .44 & .00 & .00 & 837 & 1,540 & 2,800 & 1 \\
\hline 01359967 & 14.1 & 21.4 & 17.6 & 1.39 & .02 & .05 & 979 & 1,580 & 2,550 & 1 \\
\hline
\end{tabular}

